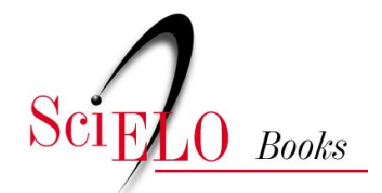

\title{
Industrialização e atitudes operárias
}

estudo de um grupo de trabalhadores

\author{
Leôncio Martins Rodrigues
}

RODRIGUES, LM. Industrialização e atitudes operárias: estudo de um grupo de trabalhadores [online]. Rio de Janeiro: Centro Edelstein de Pesquisas Sociais, 2009, 201p. ISBN: 978-85-7982-0229. Available from SciELO Books <http://books.scielo.org $>$.

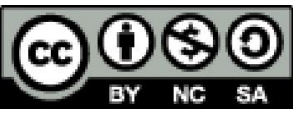

All the contents of this chapter, except where otherwise noted, is licensed under a Creative Commons Attribution-Non Commercial-ShareAlike 3.0 Unported.

Todo o conteúdo deste capítulo, exceto quando houver ressalva, é publicado sob a licença Creative Commons Atribuição Uso Não Comercial - Partilha nos Mesmos Termos 3.0 Não adaptada.

Todo el contenido de este capítulo, excepto donde se indique lo contrario, está bajo licencia de la licencia Creative Commons Reconocimento-NoComercial-CompartirIgual 3.0 Unported. 


\section{BIBLIOTECA VIRTUAL DE CIÊNCIAS HUMANAS}

\section{INDUSTRIALIZAÇÃO}

\section{E ATITUDES OPERÁRIAS}

ESTUDO DE UM GRUPO DE TRABALHADORES

\section{Leôncio Martins Rodrigues}

centro edelstein de pesquisas sociais 


\section{Industrialização e atitudes operárias}

\section{Estudo de um grupo de trabalhadores}

Rio de Janeiro

$$
2009
$$

Esta publicação é parte da Biblioteca Virtual de Ciências Humanas do Centro Edelstein de Pesquisas Sociais - www.bvce.org

Copyright (c) 2009 Leôncio Martins Rodrigues

Copyright (C) 2009 desta edição on-line: Centro Edelstein de Pesquisas Sociais Ano da última edição: 1970, Editora Brasiliense

Nenhuma parte desta publicação pode ser reproduzida ou transmitida por qualquer meio de comunicação para uso comercial sem a permissão escrita dos proprietários dos direitos autorais. A publicação ou partes dela podem ser reproduzidas para propósito não comercial na medida em que a origem da publicação, assim como seus autores, seja reconhecida.

ISBN: 978-85-7982-022-9

Centro Edelstein de Pesquisas Sociais

www.centroedelstein.org.br

Rua Visconde de Pirajá, 330/1205

Ipanema - Rio de Janeiro - RJ

CEP: 22410-000. Brasil

Contato: bvce@centroedelstein.org.br 


\section{SUMÁRIO}

Introdução.

Capítulo I: Imigração e Mobilidade Social.

A origem da mão de obra ....................................................................

Formação profissional, turnover e nível de escolaridade ........................... 6

Melhoria de vida e ascensão social..................................................... 25

Capítulo II: Os Trabalhadores e a Empresa ..............................................37

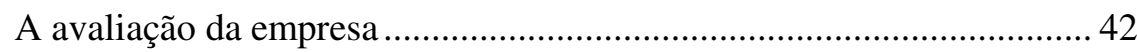

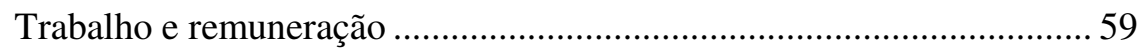

A formação da classe: atitudes ante a industrialização e o capitalismo.. 76

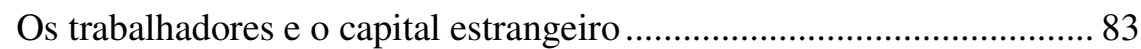

Capítulo III: Os Trabalhadores e o Sindicato ........................................... 92

Tipos de atitudes ante o sindicato......................................................... 101

O proletariado, a empresa e o sindicalismo .......................................... 105

Urbanização e sindicalização.................................................................. 113

Capítulo IV: Os Trabalhadores e a Política …………………………..... 119

Autoritarismo e populismo ................................................................. 125

Comportamento eleitoral e atitudes políticas ....................................... 135

Características da industrialização e consciência operária ..................... 148

Conclusão

A pesquisa: procedimento metodológico ……………………………........ 177

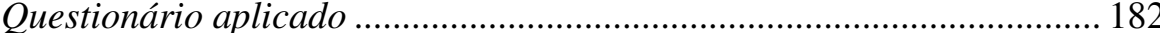

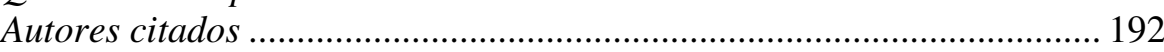




\section{INTRODUÇÃo}

A expansão industrial brasileira dos últimos decênios, em particular a ocorrida na década de 1950 , quando se registraram as mais altas taxas de crescimento do produto industrial, acentuou a importância política das camadas sociais características das sociedades modernas. As orientações e atitudes dos grupos socioprofissionais de formação recente apenas começam a ser analisadas. O estudo das condutas desses grupos, que a industrialização trouxe para a arena da vida política e social, confunde-se com a própria análise da formação da sociedade moderna no Brasil e de suas possibilidades e formas futuras de expansão. De modo geral, as investigações e estudos, de natureza sociológica, política ou econômica, têm-se inclinado, preferentemente, para o exame dos grandes processos macrossociais, relacionados com a problemática do desenvolvimento econômico do país, tema que, justificadamente, absorve as preocupações fundamentais da inteligenzia do Terceiro Mundo. Contudo, em função mesmo do interesse evidente que despertam as indagações sobre a viabilidade das formas alternativas do desenvolvimento, se fazem também necessários estudos de âmbito mais restrito, incidindo especialmente sobre as novas categorias sociais surgidas com a industrialização, de modo a poder definir suas orientações políticas, os valores e expectativas que balizam sua conduta, o modo como buscam expressar suas reivindicações ante a sociedade global e os poderes instituídos, o tipo de relacionamento que estabelecem entre si, etc. Constitui lugar-comum sublinhar a escassez de pesquisas empíricas nesta área. A carência de recursos materiais e humanos, os obstáculos que se elevam para o desenvolvimento das ciências sociais no Brasil, por si bastariam para indicar que os trabalhos de investigação científica não poderiam estar amplamente difundidos e que um longo caminho ainda resta a percorrer. Mas não parece que caiba insistir demasiadamente sobre nossas lacunas. A partir da década de 1950 um promissor impulso de investigação sociológica voltada para o presente, para os grupos e camadas sociais emergentes, para os efeitos do impacto da industrialização e para a compreensão dos problemas relacionados à formação da sociedade urbanoindustrial, aumentou a soma de conhecimentos sobre a "realidade brasileira". Nesta linha de preocupações, ainda que lastreados em orientações metodológicas diversas, numerosos trabalhos de pesquisa permitiram uma apreciação mais rigorosa dos grupos e camadas sociais postos em movimento pela ebulição política e social que o crescimento econômico ocasionou. Basta lembrar as pesquisas sobre o negro e o preconceito racial no Brasil, as investigações sobre o comportamento político dos estudantes, sobre as camadas operárias e o sindicalismo, sobre as camadas empresariais, sobre os grupos econômicos e financeiros, sobre os migrantes de origem rural, sobre a formação do Estado brasileiro, etc.

Aproximando-se deste tipo de estudo, o presente trabalho tem como tema as atitudes e orientações de um grupo operário de uma grande indústria estrangeira operando no ramo automotriz.

As atitudes dos operários ante o trabalho fabril e a sociedade industrial não são as mesmas em todas as épocas e em todos os países. Embora seja possível encontrar certos componentes "universais" do comportamento operário, que decorrem da posição que a classe ocupa no sistema de produção e na sociedade inclusiva (defesa de seus interesses profissionais e econômicos, de sua autonomia organizatória, etc.) as formas de organização sindical e política, assim como as ideologias, têm variado segundo as características do processo de industrialização, do modo particular de formação da classe, do sistema político imperante, etc.

Para fins do presente estudo, dar-se-á especial ênfase - entre as múltiplas variáveis capazes de afetar as orientações dos grupos operários à origem, ou seja, ao meio de proveniência do trabalhador. Abstratamente, quando se estuda a origem da classe operária num momento dado, podemse distinguir os seguintes setores sociais de recrutamento da mão de obra: a) setor rural; b) setor artesanal; e) setor operário d) setor de serviço "marginal"; e) classes médias.

Certamente, as fontes de recrutamento não são mutuamente excludentes para o conjunto da classe. As formas concretas de formação da sociedade industrial nos diferentes países podem indicar o peso relativo da contribuição de cada um dos setores.

A importância do meio social de proveniência da classe operária deriva do fato de que pode determinar atitudes diversas com relação à implantação da grande indústria, o trabalho industrial, o sindicalismo, a política, etc. Importa aqui, principalmente, distinguir se a incorporação ao meio industrial é percebida pelos trabalhadores como um processo de ascensão ou de rebaixamento social. Nos países de antiga industrialização (Inglaterra, França, Alemanha) a força de trabalho para a indústria nascente 
foi buscada entre a população rural e artesãos urbanos. Não importa tanto, no caso, saber se a integração à indústria significou efetivamente um rebaixamento das condições materiais de existência, mas sim como ela foi sentida pelos atores sociais. A maneira como se efetivou a implantação do capitalismo industrial na Inglaterra, França, Bélgica, Alemanha, etc., permaneceu na história, principalmente na história do movimento operário, como um modelo universal, que deveria suscitar padrões relativamente semelhantes de ações e ideologias operárias onde quer que o moderno sistema de produção fabril se implantasse.

A posterior extensão da industrialização para outros países, em outros meios socioculturais e em outras condições tecnológicas, em situações políticas distanciadas das que presidiram a velha industrialização europeia, evidenciou que as ideologias operárias se afastavam do primitivo modelo. No caso particular do Brasil, para se ir mais a fundo na explicação do comportamento, das atitudes e ideologias do proletariado brasileiro, não basta se ater aos componentes gerais que originam esta ou aquela reação da classe (aspirações por melhores condições de trabalho, salários mais elevados, etc.) mas antes buscar captar os modos concretos através dos quais as "aspirações universais" da classe se expressam.

Nas condições da industrialização brasileira, podem-se, grosseiramente, distinguir duas etapas relacionadas ao recrutamento da mão de obra fabril. Na primeira, de implantação do capitalismo industrial, o recrutamento da força de trabalho se fez mediante o recurso a fontes externas. Os imigrantes europeus constituirão a parcela mais importante da mão de obra paulista. Espanhóis, italianos e portugueses, principalmente, fornecerão os maiores contingentes operários para as primeiras indústrias paulistas. Posteriormente, após a Primeira Guerra Mundial, e principalmente na década de 1930, com o declínio das grandes correntes migratórias europeias, ocorrerá a rápida substituição do elemento estrangeiro pelo trabalhador brasileiro. Em termos dos setores de recrutamento, majoritariamente, a nova mão de obra é originária do setor rural e dos setores "marginais" de serviço das grandes cidades. Considerando-se as características da industrialização brasileira e da sociedade nacional, percebe-se porque o recrutamento da força de trabalho far-se-á nesses setores. Em primeiro lugar, em consequência do decréscimo da entrada de imigrantes europeus, à disposição dos empresários só estava o enorme reservatório de trabalhadores de origem rural. O declínio da lavoura de exportação, e principalmente a crise do café após 1930, reduziu a capacidade de criação de empregos no setor agrícola, liberando uma mão de obra excedente que viria formar os contingentes "marginais" das grandes cidades. Em segundo lugar, inexistia um setor artesanal desenvolvido, capaz de fornecer à indústria a força de trabalho de que esta necessitava para sua expansão. Em terceiro lugar, as transformações da tecnologia industrial, levando à desqualificação do trabalho, permitia a absorção de trabalhadores nacionais de baixa qualificação a fim de realizarem tarefas simples e repetitivas que não requeriam uma efetiva e prévia formação profissional.

$\mathrm{O}$ aparecimento da grande indústria, entre nós, não foi o resultado de um processo, relativamente demorado, de sucessivas transformações técnicas favorecendo as indústrias voltadas para a produção em série. $\mathrm{O}$ declínio da capacidade para importar com a deterioração dos termos do intercâmbio internacional, ao estimularem a produção interna para substituir o produto estrangeiro, fizeram com que as indústrias se instalassem no país utilizando uma tecnologia criada nos países centrais, sem passarem por uma fase de acumulação prévia de capital, especificamente, sem passarem por uma fase artesanal. Este processo de industrialização substitutiva de importações, embora largamente dependente do exterior para a obtenção de divisas, de equipamento, de know-how, não foi sentida negativamente pelas diferentes camadas sociais. Ela modificou as correlações de poder e influencia dos diferentes grupos e setores sociais, mas, de um modo geral, não prejudicou suas condições materiais de existência. Daí não se deve deduzir que os resultados da industrialização tenham beneficiado de modo igual aos diversos grupos. De fato, nas condições de uma política econômica substitutiva de importações, destinada a atender um mercado interno já existente, e essencialmente urbano, a industrialização ocorrida nas cidades em pouco ou nada afetou o padrão de vida das populações rurais pobres, a não ser pela abertura de novas fontes de emprego no meio urbano. Porém, os baixos níveis de consumo vigorantes entre as populações do setor primário estão associados antes com a natureza do relacionamento que se estabeleceu, desde a colonização, com o mercado externo do que com a desagregação de modos de vida tradicionais sob o impacto da industrialização capitalista. Tal desenvolvimento explica, em parte, a valorização do emprego industrial e do meio urbano por parte das populações rurais e marginalizadas das grandes cidades, e as dificuldades encontradas para a penetração e difusão, entre os setores operários 
originários da agricultura, das ideologias coletivistas e anticapitalistas que marcaram o movimento operário dos países de antiga industrialização.

Certamente, as lideranças do "velho" proletariado paulista, do período anterior a 1920, foram fortemente impregnadas pelos ideais socialistas de reconstrução social. Porém, observando mais de perto a composição profissional do que se convencionou chamar de "vanguarda operária" das duas primeiras décadas do século, verifica-se que o núcleo do movimento operário estava constituído pelos setores artesanais: sapateiros, pedreiros, alfaiates, marceneiros, carpinteiros, etc., onde o oficio e a consciência profissional conservavam toda sua importância. O prosseguimento da industrialização, levando à predominância dos grandes estabelecimentos fabris, reduziu a influência das pequenas oficinas nas quais a organização do trabalho e da produção dependia da qualificação operária. $\mathrm{O}$ peso e a influência dos antigos grupos de operários qualificados, consequentemente, diminuíram progressivamente em meio a uma nova massa de trabalhadores semiqualificados das indústrias de produção em série. Este processo implica o deslocamento do eixo do movimento operário para os trabalhadores das indústrias hoje chamadas "tradicionais", ou seja, as indústrias de bens de consumo não duráveis: têxtil, gráfica, de calçados, de alimentação, de vestuário, de bebidas, etc. Tecelões, gráficos e ferroviários substituem os padeiros, marceneiros e pintores como as categorias mais aguerridas e reivindicativas, dotadas de maior poder de pressão. Ainda na década de 1950, nos grandes movimentos grevistas de 1953, em São Paulo, os trabalhadores das indústrias de fiação e tecelagem, ao lado dos metalúrgicos, constituem a massa de grevistas e lideram o movimento.

O impulso "desenvolvimentista" do segundo período da década de 1950, quando a industrialização substitutiva atinge seu auge, modificará novamente a estrutura industrial brasileira e a composição profissional da mão de obra. A participação dos ramos têxteis, gráficos, de bebidas, de alimentação, etc., em termos de valor da produção e de pessoal empregado, diminui no conjunto da indústria brasileira. Uma visão sumária da evolução ocorrida pode ser observada no quadro abaixo. Note-se que a participação do setor de bens de capital passa de 4,1\%, em 1949, para 11,3\%, em 1966, enquanto o setor de bens de consumo não duráveis declina, no mesmo período, de $65,2 \%$ para $39,9 \%$.
Estrutura da produção por usos (em \%)

Bens de capital

Bens intermediários

Bens de consumo durávei

Bens de consumo não duráveis

\begin{tabular}{c|c}
1949 & 1966 \\
4,1 & 11,3 \\
26,2 & 36,8 \\
4,5 & 12,5 \\
65,2 & 39,4 \\
& $(100,0)$
\end{tabular}

No ramo têxtil, em particular, assiste-se mesmo à redução absoluta do número de trabalhadores empregados, enquanto aumenta o volume de operários nos setores "dinâmicos", como de material de transporte, material elétrico, químico, mecânica pesada, ou seja, nos ramos produtores de bens de consumo durável e de bens de capital. ${ }^{1}$

Em decorrência destas transformações na estrutura industrial brasileira, surge, em São Paulo mais particularmente, uma "nova classe operária". Contudo, ela não estará, como no passado, concentrada em alguns bairros relativamente próximos do centro, mas espalhada na periferia, na região do "Grande São Paulo". As novas indústrias, relativamente libertas das antigas vias de abastecimento ferroviário, afastam-se dos velhos bairros operários - como Brás, Mooca, Belém - para se localizarem ao longo das linhas de comunicação rodoviária.

Faltam estudos sobre este novo proletariado que permitam uma melhor inteligência de suas atitudes, valores e ideologia ante a empresa, o trabalho fabril, a sociedade urbana, o sindicato, a política, etc. As poucas pesquisas realizadas permitem supor que se trata de setores operários de algum modo diferentes do proletariado dos velhos bairros operários. É provável que, nas áreas de indústria tradicionais, a mão de obra atualmente empregada seja, em muito maior proporção, originada do próprio meio operário, de famílias de origem europeia, ao passo que, na periferia do "Grande São Paulo", de industrialização recente, a composição da força de trabalho mostre a presença de ponderáveis efetivos originários de "áreas tradicionais", isto é, da agricultura e de pequenas cidades do interior. Para estas novas camadas, o processo de incorporação à indústria adquire outro significado, associando-se com frequência a um processo de ascensão social

1 Os algarismos do quadro anterior foram extraídos do Programa Estratégico de Desenvolvimento (1968-1970), estudo especial, “A Industrialização Brasileira: Diagnóstico e Perspectivas”, Ministério do Planejamento e Coordenação Geral, janeiro de 1969, p. 131. 
ou de melhoria de vida, o que não poderia ocorrer com os trabalhadores dos antigos bairros, originários de famílias já operárias.

Contudo, o impulso industrial paulista da fase "desenvolvimentista" não se acompanhou de significativo avanço das camadas operárias em termos de agressividade reivindicativa, fortalecimento dos sindicatos e participação política. Este fato tem levado, algumas vezes, a se falar de um "aburguesamento" do proletariado paulista, termo que não nos parece adequado. Na realidade, apesar dos níveis salariais mais elevados do que em outras regiões do Brasil, apesar do avanço da industrialização e da urbanização, a área do "Grande São Paulo" encontra-se ainda bastante distanciada da situação existente na América do Norte e na Europa Ocidental para que se possa falar num "aburguesamento" da classe operária, se com isso se entende uma efetiva integração numa economia de consumo de massa e de bem-estar. Parece-me que o relativo alheamento da nova classe operária paulista no que toca ao sindicato e à atividade política deriva de outros fatores, que procuraremos ressaltar neste livro.

As investigações sociológicas que tomam os trabalhadores industriais como objeto de estudo estão apenas começando no Brasil. A maior parte dos escritos existentes orientaram-se, de preferência, para os componentes ideológicos e organizatórios da classe. Quanto ao primeiro aspecto, a grande cópia de material existente é de cunho político. Do prisma sociológico, cumpre citar os estudos de Azis Simão ${ }^{2}$ e de José Albertino Rodrigues ${ }^{3}$, que ofereceram importante contribuição para o conhecimento do movimento sindical no Brasil. Com relação aos grupos operários propriamente ditos, em "estado puro" seríamos tentados a dizer, o trabalho pioneiro e o de Juarez R. Brandão Lopes ${ }^{4}$ sobre trabalhadores de uma indústria metalúrgica, cuias observações, decorridos mais de dez anos,

\footnotetext{
${ }^{2}$ Azis SIMÃO, O Sindicato e o Estado, São Paulo, Dominus Editora, 1966. Ver também do mesmo autor: "Industrialisation et Syndicalisme au Brésil", Sociologie du Travail, Paris n. ${ }^{\circ}$, 1961, e "O Voto Operário em São Paulo", Anais do I Congresso Brasileiro de Sociologia, São Paulo, 1955.

${ }^{3}$ José Albertino RODRIGUES, Sindicato e Desenvolvimento no Brasil, São Paulo, Difusão Europeia do Livro, 1968.

${ }^{4}$ Juarez Rubens Brandão LOPES, “O Ajustamento do Trabalhador à Indústria: Mobilidade Social e Motivação". Os resultados desta pesquisa foram publicados pela primeira vez no livro de Bertram HUTCHINSON, Mobilidade e Trabalho, Rio, C.B.P.E., 1960. Foram republicados pelo autor no livro Sociedade Industrial no Brasil, São Paulo, Difusão
} Europeia do Livro, 1964. Para nossas citações, utilizaremos esta última edição. conservam toda a atualidade e constituem uma fonte de consulta indispensável para a análise do comportamento operário no Brasil.

Nossa pesquisa tem uma pretensão modesta: nada mais anseia do que poder oferecer novos dados e quiçá algumas hipóteses para a análise sociológica da classe operária brasileira. Deve ser entendida como um trabalho exploratório, que visa levantar informações e possibilitar elementos para futuras e mais completas investigações científicas neste campo. O objeto da presente pesquisa é constituído por um grupo de trabalhadores de uma indústria automobilística. Obviamente, não pretendemos, em nenhum momento, que os operários que compuseram a amostra sejam representativos da totalidade do proletariado brasileiro. Pensamos, no entanto, que algumas das conclusões a que chegamos podem ser estendidas, de algum modo, aos grupos operários de formação recente das grandes e modernas empresas industriais instaladas nos últimos anos. Ora, com tal perspectiva de análise, os fatores relacionados às orientações sindicais e políticas do grupo, aos valores que norteiam seu comportamento, não podem ser buscados simplesmente no âmbito da empresa. É desnecessário dizer que as atitudes ante a companhia advêm, em grande parte, das particularidades da própria empresa (salários, política de relações humanas, possibilidades de promoção e ascensão na firma, etc.). Porém, por outro lado, essas mesmas atitudes formam-se em decorrência do background cultural e social do grupo, anteriores à situação de trabalho na fábrica pesquisada. Ora, esse aspecto só pode ser captado remontando-se à formação da classe e, consequentemente, tendo-se como um pano de fundo as características da sociedade industrial no Brasil. Isso significa que o comportamento do grupo investigado não pode ser corretamente analisado se não se tiverem em conta os fatores que ultrapassam a situação de trabalho na fábrica. O tipo de explicação proposto implica, assim, na constante referência aos atributos e variáveis que se situam tanto no plano da empresa como no da sociedade inclusiva, considerados em sua interação. Assim sendo, o material levantado na companhia é insuficiente, o que nos obrigou a recorrer a outras fontes de informação e a outros documentos relativos ao proletariado brasileiro no seu conjunto.

O Grupo Estudado - Os trabalhadores que compuseram a amostra foram selecionados de uma das maiores empresas automotrizes do país, localizada no "Grande São Paulo" - como quase todas, aliás. Nas páginas que se seguem a denominaremos, ficticiamente, de Empresa Automobilística. 
Para os propósitos de estudo de um segmento do "novo proletariado" sua escolha ofereceu as seguintes vantagens: em primeiro lugar, a grande maioria da mão de obra diretamente produtiva é formada de trabalhadores semiqualificados, isto é, de trabalhadores treinados para a realização de tarefas repetitivas que não requerem alto grau de aperfeiçoamento técnico-profissional. A Empresa Automobilística ocupa, contudo, algumas categorias profissionais dotadas de alta qualificação, como é o caso dos ferramenteiros, o que nos permitiu a comparação entre os setores qualificados e não qualificados.

Em segundo lugar, sendo uma indústria recentemente instalada no Brasil, passando por uma fase de crescimento, absorveu novas camadas operárias, entre as quais parcela ponderável há pouco chegada da agricultura ou de áreas tradicionais. Em terceiro lugar, na medida em que a Empresa Automobilística aparece como símbolo do avanço da industrialização, sob a forma de capital privado e estrangeiro, ela constitui um local privilegiado para o exame das atitudes operárias ante o capitalismo contemporâneo implantando-se numa sociedade pouco industrializada.

A pesquisa foi realizada em 1963. Com o auxílio de questionários, foram entrevistados 86 trabalhadores. Nas tabelas, para fins de análise, o grupo foi dividido em subgrupos, que aparecem sob as seguintes rubricas:

Ferramenteiros: operários altamente qualificados;

Operários: operários semiqualificados;

Urb.: operários sem experiência de trabalho na agricultura;

Agric.: operários com experiência de trabalho na agricultura;

Urb.: operários nascidos e educados nos grandes centros urbanos;

Trad.: operários originários de áreas tradicionais ${ }^{5}$.

Os trabalhadores não ligados diretamente à produção foram excluídos da amostra. O leitor interessado em informações mais pormenorizadas sobre a amostra e os procedimentos metodológicos utilizados poderá encontrá-los no final deste livro. Aqui, limitamo-nos a apresentar as

\footnotetext{
${ }^{5}$ Usamos o termo "áreas tradicionais" na falta de outro melhor para designar as regiões escassamente industrializadas e urbanizadas. Dada a presença, no Brasil, da grande lavoura produzindo para o mercado (externo, principalmente), objetivando o lucro e utilizando mão de obra assalariada, faltam aqui alguns dos elementos que tipicamente são tomados para a caracterização da comunidade tradicional. Porem, o sistema de relações sociais, a cultura dessas áreas e os padrões de comportamento de suas populações afastam-se tipicamente daqueles vigentes nas civilizações industriais modernas; por isso, não pareceu excessivamente arbitrária a utilização do conceito.
}

informações relacionadas à pesquisa apenas na medida em que são estritamente necessárias para a leitura das páginas que se seguem. 


\section{IMIGRAÇÃO E MOBILIDADE SOCIAL}

$\mathrm{O}$

presente capítulo destina-se a oferecer ao leitor algumas indicações sobre as características mais gerais dos trabalhadores da Empresa Automobilística, especialmente aquelas relacionadas ao seu background profissional e social. Assim, antes de passar à análise de suas atitudes ante a empresa, o sindicato e a política, cumpre proporcionar algumas informações preliminares sobre o grupo estudado, de modo a que se possa entender melhor suas motivações, valores e aspirações ante o trabalho e a sociedade. Portanto, esta parte permanece essencialmente num nível descritivo, assentando e pondo em relevo determinados dados que servirão para apoiar as interpretações subsequentes.

\section{A ORIGEM DA MÃO DE OBRA}

De acordo com esse esquema de exposição, cumpre preliminarmente verificar a origem do grupo estudado, questão que, em escala reduzida, refere-se à da própria formação da camada operária em São Paulo: De que setores se recrutam a mão de obra industrial paulistana? Quais suas experiências profissionais? Qual seu nível de escolaridade?

No sentido das indagações anteriores, o primeiro fato a ser destacado e que apenas $15 \%$ dos operários incluídos na amostra nasceram no "Grande São Paulo". A grande maioria (53\%) nasceu no interior do Estado, contribuindo as demais regiões com $26 \%$ e o Exterior com $4 \%$. Entre os ferramenteiros - a categoria profissional mais qualificada entre os operários da empresa - a proporção de nascidos no "Grande São Paulo" ascendeu a 28\%.

Contudo, o aspecto sociologicamente significativo não é tanto o local de nascimento, mas a atividade profissional a que se dedicava parte desses trabalhadores antes de se deslocarem para São Paulo. Está-se em presença de um grupo operário composto maciçamente de trabalhadores de origem ${ }^{1}$ Entendemos por "Grande São Paulo" apenas os municípios de São Paulo, Santo André, São
Bernardo, São Caetano e Osasco. agrícola, mais precisamente de operários que tiveram algum tipo de experiência de trabalho na agricultura, seja como assalariados agrícolas, seja como pequenos proprietários, meeiros ou rendeiros. Como seria de se esperar, a proporção de trabalhadores de origem agrícola é mais elevada nos níveis salariais inferiores e consideravelmente mais baixa entre os trabalhadores qualificados. Note-se, no quadro abaixo, que $53 \%$ dos operários entrevistados tinham tido experiência de trabalho na agricultura, enquanto, entre os ferramenteiros, essa cifra baixava para $17 \%$.

Tabela 1: Distribuição quanto à origem

Trabalharam na agricultura

Não trabalharam na agricultura

\begin{tabular}{|c|c|}
\hline Operários & Ferramenteiros \\
$53 \%$ & $17 \%$ \\
47 & 83 \\
$(100 \%)$ & $(100 \%)$ \\
\hline
\end{tabular}

Não se dispõe de estatísticas gerais relativas à proporção de trabalhadores de origem rural no conjunto da mão de obra industrial paulista. Em pesquisa efetuada com trabalhadores de uma indústria metalúrgica (fevereiro-abril de 1957) Juarez Brandão Lopes ${ }^{2}$ relacionou a origem da mão de obra com a qualificação profissional: entre os trabalhadores não qualificados e semiqualificados $(\mathrm{n}=329)$ somente $7,0 \%$ eram provenientes da cidade de São Paulo; $48,9 \%$ vinham do interior deste e de outros Estados (excetuando-se o Nordeste); $25,2 \%$ do Nordeste e $18,9 \%$ de países estrangeiros. Entre os operários qualificados, controladores e contramestres $(n=50)$, a proporção de trabalhadores nordestinos baixava consideravelmente $(2,0 \%)$ enquanto se elevava a participação de paulistanos natos $(14,0 \%)$ e a de trabalhadores estrangeiros atingia $62,0 \%{ }^{3}$

\footnotetext{
2 Juarez R. Brandão LOPES, Sociedade Industrial no Brasil, cap. II, "O Ajustamento do Trabalhador à Indústria: Mobilidade Social e Motivação", São Paulo, Difusão Europeia do Livro, 1964, p. 32.

${ }^{3}$ Além da carência de mão de obra qualificada e de técnicos nacionais, a presença, neste setor, de elevados contingentes de estrangeiros explica-se pelo fato de que, apesar do acentuado declínio das correntes migratórias externas, nos últimos anos o elemento qualificado passou a entrar em volume considerável- mente superior ao do não qualificado. Assim, em 1946, entraram no Estado de São Paulo, vindo de outros países, 447 operários qualificados e 101 não qualificados. Em 1951, os primeiros atingiram 7.606 enquanto os segundos apenas 755. Manuel DIEGUES JÚNIOR, Imigração, Urbanização, Industrialização, Rio, Centro Brasileiro de Pesquisas Educacionais, 1964, p. 315.
} 
Indica Juarez R. Brandão Lopes que a quase totalidade dos trabalhadores originários do interior do Estado de São Paulo e de outros Estados exercia algum tipo de atividade agrícola antes de se dirigir para as cidades. "Os nordestinos (incluindo-se neste grupo os baianos), em sua maioria, provêm de famílias de sitiantes e, às vezes, de meeiros. O grupo de trabalho nas suas propriedades é a família numerosa, auxiliada, às vezes no caso dos sitiantes, por poucos empregados. A agricultura é de subsistência; apenas "sobras" eventuais são vendidas nas feiras locais. Nas propriedades de alguns, porém, principalmente nas próximas da zona litorânea, fora do Polígono da Seca, uma parte maior da produção agrícola e da criação é destinada ao mercado. Por outro lado, os operários do interior de São Paulo, embora sejam muitas vezes, como os nordestinos, de famílias de sitiantes e de meeiros, devido à economia mais desenvolvida da região, plantavam em suas terras café ou algodão (bem como outros produtos) para o mercado, tendo as roças de "mantimento" para o consumo da família um papel secundário nas suas atividades agrícolas. São também mais frequentes que no grupo do Nordeste os paulistas que eram camaradas ou colonos em fazendas". ${ }^{4}$ Indicações que comprovam a presença de forte contingente operário de origem rural na indústria paulista são encontradas também na pesquisa efetuada por Luiz Pereira em várias fábricas da capital. ${ }^{5}$

Desse ângulo, portanto, a situação na Empresa Automobilística parece não se diferenciar notavelmente da registrada em outras empresas de São Paulo. O proletariado paulista, pelo que indicam as pesquisas realizadas, parece composto em grande parte por trabalhadores nacionais nascidos em áreas rurais ou em pequenas cidades do interior de São Paulo e outros Estados. A inexistência de informações mais amplas sobre a formação do proletariado paulistano, entretanto, não permite estabelecer exatamente qual a proporção de trabalhadores de origem agrícola no conjunto da mão de obra industrial. A participação do elemento estrangeiro, apesar de muito ter diminuído - em comparação com a primeira década do século - ainda permanece importante, principalmente entre os setores mais

\footnotetext{
${ }_{5}^{4}$ Ibid., p. 33.

${ }^{5}$ Luiz PEREIRA, Trabalho e Desenvolvimento no Brasil, São Paulo, Difusão Europeia do Livro, 1965.
}

qualificados. Na Empresa Automobilística, os estrangeiros compreendiam $9,35 \%$ do total de operários existentes em todas as suas secções e fábricas. ${ }^{6}$

A presença do "passado rural" não se expressa somente na experiência pessoal e direta com o trabalho na lavoura. Na maior parte dos casos, os trabalhadores são descendentes de lavradores (pequenos proprietários, rendeiros ou assalariados agrícolas). Entre os operários entrevistados encontramos $63 \%$ cujos pais haviam anteriormente trabalhado na agricultura; entre os ferramenteiros a porcentagem decaía para $29 \%$.

Outro aspecto a assinalar na descrição do grupo estudado é o fato de se tratar de trabalhadores imigrados recentemente para São Paulo. Trata-se de uma classe operária "jovem", sem tradição de trabalho industrial e de vida num grande centro urbano.

\begin{tabular}{|l|c|c|}
\multicolumn{2}{|c|}{ Tabela 2} \\
\hline \multicolumn{1}{|c|}{ Data de chegada a São Paulo } & Operários & Ferramenteiros \\
\hline Antes de 1939 & $4 \%$ & $19 \%$ \\
De 1939 a 1943 & 14 & - \\
De 1944 a 1948 & 14 & 25 \\
De 1949 a 1953 & 17 & 19 \\
De 1954 a 1958 & 26 & 37 \\
De 1959 a 1963 & 25 & - \\
& $(100 \%)$ & $(100 \%)$ \\
Sem resposta & $2 \%$ & - \\
$n=$ & 53 & 16 \\
\hline
\end{tabular}

Obs.: Porcentagens extraídas excluindo-se os que não responderam.

Mais da metade dos operários nascidos em outras localidades estão vivendo em São Paulo há menos de dez anos. A porcentagem dos que chegaram depois de 1959 é relativamente elevada, atingindo um quarto do total. Note-se, por outro lado, que nem um só ferramenteiro tem menos de cinco anos de vivência na capital, tomando- se como ponto de referência a data de aplicação dos questionários (segundo semestre de 1963).

Como evidenciaram outros estudos, as correntes migratórias do campo e das pequenas cidades para as metrópoles, São Paulo em particular, estão relacionadas à busca de melhores oportunidades e aspirações de

${ }^{6}$ A proporção do elemento estrangeiro é bem mais elevada entre os trabalhadores de escritório, entre os técnicos e engenheiros. Neste grupo, os dados registram 18,37\% de estrangeiros no total de empregados. 
ascensão social. Os dados levantados na Empresa Automobilística indicam claramente tais motivações dos migrantes. Convém insistir neste ponto porque as aspirações que ensejam as correntes migratórias constituem um componente relevante para a compreensão das atitudes operárias ante a empresa, o trabalho e a sociedade global.

Tabela 3: "Por que o Sr. veio para São Paulo?”

\begin{tabular}{|l|c|c|}
\hline & Operários & Ferramenteiros \\
Veio à procura de melhores condições de vida e de trabalho & $79 \%$ & $44 \%$ \\
Veio com a família, quando criança & 17 & 31 \\
Veio para estudar & - & 6 \\
Veio para prestar serviço militar & - & 6 \\
Por outros motivos & 4 & 13 \\
& $(100 \%)$ & $(100 \%)$ \\
Sem resposta & $2 \%$ & - \\
$\mathrm{n}=$ & 52 & 16 \\
\hline
\end{tabular}

Obs.: Porcentagens extraídas excluindo-se os que não responderam.

Comparando-se as duas categorias, operários e ferramenteiros, chama atenção à porcentagem mais elevada de operários que, já adultos, deslocaramse para São Paulo em busca de melhores oportunidades profissionais. Entre os ferramenteiros encontra-se uma proporção relativamente superior de indivíduos que vieram, quando crianças, com as famílias, o que era de se esperar, uma vez que entre os trabalhadores de menor qualificação, é que se encontra o maior volume de entrevistados chegados há pouco a São Paulo. Chama a atenção também o fato de não se encontrar, entre os operários, um só que tenha vindo para estudar (os ferramenteiros que vieram com tal objetivo são todos descendentes de japoneses). Excluindo-se os que se dirigiram para São Paulo com os pais, verifica-se que a quase totalidade estava movida por uma única aspiração: obter condições de vida superiores às dos lugares de origem. Conjuga-se, no processo migratório, a luta pela sobrevivência, o desejo de "melhorar de vida" e aspirações mais definidas de ascensão social.

"Vim com vinte anos, tentar a sorte em São Paulo; a vida de trabalhar na lavoura não dava futuro".

"Fui criado com minha avó na fazenda. Vim para São Paulo em busca de melhoria".

"Lá eu tinha uma vida incerta. Trabalhava com meu pai; a gente arrendava terra para plantar. Aqui eu sabia que teria mais facilidade de emprego. Poderia ajudar meus pais. Todos os meses mando dinheiro para eles".
Cumpre deixar claro que as aspirações de melhoria de vida, no processo migratório, não se encontram unicamente entre os trabalhadores originários da agricultura. São encontradas - talvez de modo mais nítido entre os trabalhadores originários de pequenas cidades do interior (Estado de São Paulo inclusive), que já trabalhavam como operários. É claro que, neste caso, não se poderia falar de mudanças de status profissional e de migração rural-urbana tal como ocorre entre os que abandonam a ocupação na agricultura. Entre os trabalhadores que compuseram a amostra, encontramos 33\% de indivíduos que vieram diretamente para São Paulo sem terem passado previamente pela agricultura. Contudo, como se salientou, aqui também a motivação é sempre a mesma: procura de melhores oportunidades profissionais, crença de que na cidade grande as possibilidades de ascensão social e de melhoria de padrão de vida são maiores.

"Vim para melhorar a situação. Lá só havia uma indústria mecânica. Aqui a possibilidade e maior".

"Lá tem pouca indústria, pouca escola; vim para me aperfeiçoar, para melhorar a situação econômica".

"A vida no interior era difícil. Eu era mecânico de automóvel e não tinha muito futuro. Aqui em São Paulo e melhor".

"Aos 17 anos eu trabalhava como padeiro; ganhava pouco e não tinha possibilidade de outro emprego na minha cidade. Então resolvi vir para São Paulo, pois na capital poderia me empregar melhor”.

\section{FORMAÇÃO PROFISSIONAL, TURNOVER E NÍVEL DE ESCOLARIDADE}

Considerando o baixo nível cultural das populações rurais brasileiras, as técnicas rudimentares utilizadas nas lides agrícolas, não deve surpreender, entre os trabalhadores estudados, a ausência de uma efetiva formação profissional e o baixo nível de escolaridade e, como uma de suas decorrências, a elevada taxa de mobilidade profissional. Este último aspecto já foi salientado por Juarez B. Lopes no estudo citado:

Observando-se os empregos dos entrevistados desde que chegaram pela primeira vez a São Paulo verificam- se, muitas vezes, frequentes mudanças de ocupação, não só de um ramo industrial para outro, o que era de qualquer modo de se esperar, devido à falta de qualificação dos operários empregados numa produção em série, mas também de fábricas para lojas ou para ocupações marginais como 
vendedores ambulantes, sob comissão ou por conta própria, ou saindo da cidade para voltar novamente para a lavoura. ${ }^{7}$

E o autor ofereceu os seguintes resumos de "histórias de vida" que vale a pena transcrever:

\section{S.A.D. (Ibicaraí, Bahia):}

Operário (1 ano e meio) - Volta ao sítio na Bahia (21 dias) Vendedor em base de comissão, em porta de loja (1 ano) - operário (4 anos).

C.C.F. (Jaú, São Paulo):

Lavrador em empresa de ônibus (3 meses) - Operário (8 anos) - Sítio (2 anos) - Operário (2 anos).

J.J. (Ibiquara, Bahia):

Servente de pedreiro (2 meses) - Aprendiz de padeiro (2 semanas) Operário (1 ano e meio) - Vendedor pracista na base de comissão (?) - Operário (15 dias) - Operário (2 anos e meio).

Observações no mesmo sentido são encontradas na pesquisa de Luiz Pereira, nas entrevistas realizadas com trabalhadores de origem rural. Um exemplo típico é o depoimento de um ajudante de mecânico (35 anos, curso primário completo o qual "tendo trabalhado na propriedade (agrícola) do pai, na Bahia, aos 19 anos foi servente de pedreiro em São Paulo, aos 20 anos empacotador numa casa de tecidos (atacadista) em São Paulo, a seguir (por 3 meses) - sempre na capital - ajudante numa fundição, "ajudante interno" numa fábrica de pianos ( 8 meses), vendedor ambulante por conta própria (roupa em feiras-livres em bairros) durante 5 anos, e há 4 anos "furador de chapas" (máquina de punção) numa pequena indústria mecânica..."»

É verdade que a legislação trabalhista, assegurando indenização em caso de dispensa, aliada à política das empresas de não permitir que o operário consiga a estabilidade no emprego, contribuía para dificultar períodos prolongados de serviço numa fábrica. Porem, a transferência de um tipo de atividade para outro, com mudança' do ramo industrial e de ocupação explica-se, em grande parte, pela inexistência de formação

\footnotetext{
${ }^{7}$ Juarez Brandão LOPES, op. cit., p. 41.

${ }^{8}$ Luiz PEREIRA, op. cit., p. 169. Eunice Ribeiro DURHAM encontrou igualmente elevada rotatividade profissional entre os migrantes nordestinos. Cf., Migração, Trabalho, Família, Faculdade de Filosofia, Ciências e Letras (USP), São Paulo, 1966, (mim.).
}

profissional, fato que leva os trabalhadores não qualificados a empregaremse como operários braçais em empresas dos mais diferentes ramos industriais e em outros setores da atividade econômica (comércio, agricultura, serviços, etc.). A extrema mobilidade profissional parece ser, assim, uma das características do trabalhador brasileiro.

\section{A - Instrução e preparo técnico}

O nível de escolaridade do grupo estudado é baixo, se temos em conta os requisitos educacionais situados pela sociedade moderna. Entre todos os entrevistados não se encontrou nenhum trabalhador que tivesse grau de instrução formal superior à ginasial. Apenas $4 \%$ dos operários declararam possuir ginásio completo. Entre os ferramenteiros a proporção foi de $9 \%$. Por outro lado, $6 \%$ dos operários não possuíam nenhuma instrução. Eram trabalhadores semialfabetizados que, amiúde, encontram dificuldade na simples leitura. Entre os trabalhadores chegados recentemente de áreas tradicionais (Trad.), a porcentagem dos que afirmaram não possuir nenhuma instrução atingiu $10 \%$. Observe-se, no entanto, que, entre os ferramenteiros, $70 \%$ concluíram o curso primário.

Tabela 4: Instrução dos entrevistados

\begin{tabular}{|l|c|c|c|c|}
\hline & Operários & Ferramenteiros & Mod. & Trad. \\
Nenhuma instrução & $6 \%$ & - & - & $10 \%$ \\
Primário incompleto & 30 & $4 \%$ & - & 40 \\
Primário completo & 53 & 70 & $70 \%$ & 45 \\
Ginásio incompleto & 7 & 17 & 20 & 5 \\
Ginásio completo & 4 & 9 & 10 & - \\
& $(100 \%)$ & $(100 \%)$ & $(100 \%)$ & $(100 \%)$ \\
& 62 & 24 & 22 & 20 \\
\hline
\end{tabular}

A ausência de ginásio poderia ser "compensada" de alguma maneira com algum curso técnico (curso de desenho mecânico, de rádio, etc.) mais adequado ao tipo de trabalho a que se dedicam os entrevistados. No entanto, poucos são os que fizeram ou estão fazendo algum curso de natureza técnica ou profissional. Entre os operários, cerca de dois terços responderam negativamente à pergunta: "O Sr. fez ou está fazendo algum curso técnico?". A proporção se inverte no caso dos ferramenteiros, mas é preciso notar que uma formação profissional mais aprimorada constitui precisamente forte requisito para o preenchimento das funções atribuídas a 
esse grupo. Assim sendo, chega a ser surpreendente encontrar-se, entre os ferramenteiros, trabalhadores que não realizaram nenhum curso técnico e que aprenderam a profissão "na prática".

Tabela 5. "O Sr. fez ou está fazendo algum curso técnico?"

\begin{tabular}{|l|c|c|}
\hline & Operário & Ferramenteiros \\
Sim & $24 \%$ & $5 \%$ \\
Não & 76 & 25 \\
& $(100 \%)$ & $(100 \%)$ \\
$\mathrm{n}=$ & 62 & 24 \\
\hline
\end{tabular}

O baixo nível de instrução geral acompanha-se, pois, de deficiente formação profissional e especializada. Apenas $9 \%$ dos operários cursaram escolas técnicas, sendo que $40 \%$ aprenderam a profissão na própria Empresa Automobilística. Ante a carência de mão de obra qualificada, a empresa manteve, durante certo tempo, cursos próprios para a preparação de seus trabalhadores. A experiência não resultou satisfatória e, no momento em que realizávamos a pesquisa, havia sido abandonada.

$$
\text { Tabela 6: "Onde aprendeu a profissão?" }
$$

\begin{tabular}{|l|c|c|}
\hline & Operários & Ferramenteiros \\
Aprendeu na prática, em outra fábrica & $49 \%$ & $44 \%$ \\
Aprendeu na Empresa Automobilística & 41 & 6 \\
Aprendeu em alguma escola técnica & 9 & 67 \\
Outras respostas & 2 & 18 \\
$\mathrm{n}=$ & 62 & \\
\hline
\end{tabular}

$\mathrm{n}=$

Obs.: Respostas múltiplas. Soma das porcentagens superior a 100\%.

Essa situação não parece peculiar à Empresa Automobilística. A deficiente formação técnico-profissional dos trabalhadores afeta não apenas a indústria automotriz, mas o parque manufatureiro paulista no seu conjunto. É certo que a expansão industrial do último decênio foi extremamente rápida, não propiciando em tempo oportuno à formação especializada de mão de obra. Contudo, é preciso ter em conta outros fatores, como a conhecida precariedade da rede escolar, que efetivamente não serve as camadas inferiores da população brasileira, e a valorização que a cultura tradicional concede aos empregos e ocupações não manuais. Neste contexto, a expansão das matrículas nas escolas profissionais tem sido inteiramente insatisfatória, em comparação com as necessidades do parque fabril. Observa M. Brejon que o ensino profissional foi "o que apresentou menor ritmo de desenvolvimento nos últimos 10 anos, quer se considerem os números absolutos de matrículas e o seu aumento percentual, quer se levem em conta os totais de conclusões de curso e as respectivas porcentagens calculadas sobre o total de conclusões do ensino médio. $\mathrm{Na}$ realidade, as matrículas e conclusões dos cursos industriais diminuíram, nos últimos dez anos, relativamente aos outros ramos do ensino médio".

Até que ponto os níveis profissionais e educacionais observados na Empresa Automobilística correspondem aos registrados em outras indústrias do "Grande São Paulo"? Não se tem elementos para responder a essa indagação, mas dois fatores devem ser balanceados se pensarmos na generalização dos dados obtidos no grupo de trabalhadores estudados. De um lado, a Empresa Automobilística é considerada "boa empregadora". Dotada de grandes recursos, em comparação com as empresas de menor porte, está em situação relativamente vantajosa para melhor selecionar seus empregados. Um grau mais elevado de formação técnica e de escolaridade constitui fator indispensável para a realização de determinadas tarefas. Mas, por outro lado, no caso de grande parte dos operários da Empresa Automobilística, tais requisitos são relevantes apenas do ponto de vista social: maior rapidez de adaptação à organização da empresa, maior responsabilidade, maior acatamento aos regulamentos, capacidade de ajustamento grupai, etc. Do ponto de vista estritamente técnico, os operários da linha de montagem - que compõem a maior parte da amostra - não necessitam, para o cumprimento das tarefas que lhes são assinaladas, de um nível elevado de educação formal (geral ou profissional). Não se lhes exige a leitura, a escrita, a capacidade de decifração de desenhos, conhecimento do material, de ferramentas, etc. São, no caso dos montadores, operários especializados na execução de trabalhos repetitivos que não requerem raciocínio e capacidade de decisão.

\footnotetext{
${ }^{9}$ Moysés BREJON, Racionalização do Ensino Industrial, Faculdade de Filosofia, Ciências e Letras (USP), Boletim n. ${ }^{\circ}$ 273, São Paulo, 1962, p. 197. Sobre o mesmo assunto, consulte-se também: Educação Técnica e Industrialização, Fórum Roberto Simonsen, Edição do Centro e Federação das Indústrias do Estado de São Paulo, São Paulo, 1964. Os próprios sindicatos operários demonstram pouco interesse pela elevação do nível profissional dos associados. Em 1964, em São Paulo, apenas três sindicatos mantinham cursos pré-vocacionais e o número de alunos era de apenas 135. Cf. Ophelia RABELLO, A Rede Sindical Paulista, São Paulo, Instituto Cultural do Trabalho, 1965, pp. 95 e 96.
} 


\section{B - Leituras de jornais}

Um aspecto que merece ser posto em relevo - pois constitui índice de interesse pelos fatos mais amplos da vida política do país - é o que se refere à leitura de jornais. As declarações dos entrevistados revelam que a grande maioria quase não acompanha o noticiário nacional e os acontecimentos veiculados através de jornais. Com efeito, apenas $15 \%$ dos operários leem jornais todos os dias. Entre os ferramenteiros, a porcentagem sobe consideravelmente, atingindo $44 \%$. A proporção de operários que afirmou ler "às vezes", ler "raramente" ou "nunca ler" chega quase à metade (48\%) do total de entrevistados. Entre os trabalhadores chegados a pouco de regiões pouco industrializadas (Trad.) não se encontrou um só que lesse jornais todos os dias. É certo que as respostas do tipo "lê raramente" e "lê às vezes" (na Tabela 7) carecem de maior precisão, mas são claramente indicativas de uma frequência de leitura muito baixa. Por isso, fomos obrigados a nos ater às próprias declarações dos entrevistados: "leio às vezes" ou "leio raramente". Englobando-se os que afirmaram "ler às vezes", "ler raramente" ou "nunca ler" temos, no grupo dos Trad., 65\% de entrevistados que praticamente não leem jornais, contrastando fortemente com os trabalhadores nascidos em São Paulo (Mod.) onde 43\% leem jornais diariamente. Os que afirmaram ler uma vez por semana, geralmente o fazem aos domingos.

Tabela 7: Frequência de leitura de jornais
\begin{tabular}{|l|c|c|c|c|}
\hline & Operários & Ferramenteiros & Mod. & Trad. \\
Lê todos os dias & $15 \%$ & $44 \%$ & $43 \%$ & - \\
Lê de 6 a 3 vezes por semana & 5 & 17 & - & $4 \%$ \\
Lê 2 vezes por semana & 12 & - & 11 & 4 \\
Lê 1 vez por semana & 20 & 4 & 17 & 27 \\
Lê às vezes & 20 & 31 & 17 & 27 \\
Lê raramente & 18 & 4 & 6 & 27 \\
Nunca lê & 10 & - & 6 & 16 \\
& $(100 \%)$ & $(100 \%)$ & $(100 \%)$ & $(100 \%)$ \\
Sem resposta & $5 \%$ & $4 \%$ & $4 \%$ & $5 \%$ \\
$n=$ & 62 & 24 & 22 & 20 \\
\hline
\end{tabular}

Obs.: Porcentagens extraídas excluindo-se os que não responderam.

É possível que o preço dos jornais seja um dos fatores que contribuem para dificultar sua difusão entre os operários. Para as camadas de remuneração mais baixa, o dispêndio com a aquisição diária de um jornal implica em desviar certa soma de dinheiro do orçamento doméstico. Porém, não se deve privilegiar excessivamente o fator econômico como elemento explicativo. Na escolha dos gastos "supérfluos" a soma a ser desembolsada com a compra de jornais cede lugar a outros gastos determinados pelo nível cultural do trabalhador, segundo suas preocupações e interesses. A leitura de jornais, enquanto forma de lazer ou busca de informações é preterida em favor de outros tipos de recreação ou de comunicação. Aqui, obviamente, a parcela de operários semialfabetizada encontra dificuldade na própria leitura. Mas, por outro lado, a leitura de jornais não é uma simples forma de recreação. Ela revela, de algum modo, o interesse pelos fatos da vida nacional e é, nesse sentido, índice de participação no modo de vida urbano-industrial. ${ }^{10}$ Desse ponto de vista, como outros dados virão confirmar, já nos revela o alheamento dos trabalhadores pelos acontecimentos da política brasileira.

Não se dispõe de dados sobre a frequência na leitura de jornais entre a massa trabalhadora em geral. Algumas informações escassas permitemnos supor que o observado entre os operários da Empresa Automobilística pode ser generalizado para o conjunto da classe operária, com exceção talvez dos setores altamente qualificados. Assim, Cláudio T. Vouga, em pesquisa efetuada entre operários de uma fábrica metalúrgica de São Paulo, verificou, ao estudar o conteúdo das leituras dos trabalhadores, que $16 \%$ dos entrevistados não liam publicação alguma. ${ }^{11}$

\footnotetext{
${ }^{10}$ Os jornais preferidos são os seguintes, segundo as respostas do total de entrevistados (operários e ferramenteiros): Última Hora, 28\%; Folhas (várias edições), 27\%; Diários (várias edições), 25\%; Estado de S. Paulo, 22\%; Gazeta Esportiva, 20\%; Gazeta, 4\%; "Qualquer jornal", 9\%; Brasil Urgente, 1\%; Novos Rumos, 1\%; "Diário Popular", $1 \%$. Comparando-se os sindicalizados e não sindicalizados, é a seguinte a ordem de preferência: Sindicalizados: Última Hora, 42\%; Diários, 33\%; Folhas, 29\%; Estado de São Paulo, 19\%; Gazeta Esportiva, 10\%; Brasil Urgente, 5\%; Novos Rumos, 5\%. Entre os não sindicalizados: Folhas, 27\%; Estado de São Paulo, 2.3\%; Última Hora, 23\%; Gazeta Esportiva, 23\%; Gazeta, 3\%; "Qualquer jornal", 10\%; Diário Popular, $2 \%$.

${ }^{11}$ Referimo-nos à pesquisa, ainda não publicada, efetuada por Cláudio Torres VOUGA entre os operários de uma empresa metalúrgica de cerca de mil empregados. Trata-se de uma empresa bastante diferenciada da que estudamos: pouco modernizada, com equipamento antiquado e uma linha de produção extremamente diversificada, fabricando desde equipamento para as empresas automobilísticas até pregos e ferraduras, com um tipo de trabalho que se aproxima do artesanal.
} 
Conviria não exagerar a função dos jornais como fonte de informações no caso da camada operária. O rádio e a televisão, basicamente o primeiro, desempenham importante papel e suprem, numa escala que não saberíamos precisar com exatidão, a leitura dos jornais no que tange à obtenção de informações.

$\mathrm{Na}$ verdade, neste particular, os trabalhadores da Empresa Automobilística e as camadas operárias, de modo geral, não parecem constituir uma exceção. As pequenas tiragens dos jornais brasileiros, por si só, mostram que a parcela da população que lê jornais é extremamente reduzida. Mesmo na capital paulista, no Estado mais próspero da Federação e onde a porcentagem de analfabetos é consideravelmente inferior à que se encontra em outras áreas, revelam as pesquisas de mercado que mais de um terço de população, em 1963, absolutamente não lia jornais. A fim de permitir um cotejo com os resultados evidenciados na pesquisa com os trabalhadores da Empresa Automobilística, reproduzimos os resultados obtidos num levantamento ${ }^{12}$ efetuado entre a população paulistano, em que a leitura de jornais aparece discriminada por classe social.

Tabela 8: "O Sr. lê jornais?”Apenas municípios de São Paulo. Estão excluídas as cidades que compõem o "Grande São Paulo"

\begin{tabular}{|l|c|c|c|c|}
\hline & Total & Classe A $\left(^{*}\right)$ & Classe B $\left(^{*}\right)$ & Classe C $\left(^{*}\right)$ \\
Sim & $64 \%$ & $87 \%$ & $73 \%$ & $53 \%$ \\
Não & 36 & 13 & 27 & 47 \\
& $(100 \%)$ & $(100 \%)$ & $(100 \%)$ & $(100 \%)$ \\
$\mathrm{n}=$ & 2020 & 200 & 803 & 1017 \\
\hline
\end{tabular}

Nota-se que os grupos de renda mais elevada leem mais jornais do que os de renda mais baixa. Na classe $\mathrm{C}, 47 \%$ dos entrevistados declararam simplesmente que não leem jornais. Para melhor ponderação dos algarismos acima, faz-se mister atentar para a maneira como a pergunta foi formulada. Indagou-se simplesmente se o entrevistado lia jornais e não com que assiduidade o fazia. Se a pergunta fosse formulada nestes termos: "O Sr. leu

${ }^{12}$ V. Estudos Marplan (Média e Superposição). Segundo Semestre de 1963. Marplan Pesquisas e Estudos de Mercado Ltda.

"Classes A, B e C correspondem, grosso modo, a classes altas, médias e baixas, ordenadas segundo critérios que envolvem renda, posse de utensílios de conforto doméstico, nível de escolaridade, etc. No levantamento estão incluídos indivíduos de ambos os sexos. No total da população masculina de São Paulo, $27 \%$ não leem jornais jornal ontem?", muito provavelmente os índices de respostas afirmativas seriam bem mais baixos.

Dados da mesma fonte informam que, no total, a proporção de pessoas que ouvem rádio, em São Paulo, é maior que a das que leem jornais. Entretanto, é preciso levar em consideração, aqui, a presença das ouvintes do sexo feminino, que inflaciona os algarismos dos que ouvem rádio e deflaciona os dos que leem jornais.

Tabela 9: “O Sr. ouviu rádio ontem?” (1963)

(30 dias diferentes durante um mês)

\begin{tabular}{|l|c|c|c|c|c|}
\hline \multirow{4}{*}{ Sim } & Total & Classe & Classe & Classe & Homens \\
Não & & $A$ & $B$ & $C$ & \\
& $45 \%$ & $40 \%$ & $45 \%$ & $46 \%$ & $41 \%$ \\
$\mathrm{n}=$ & 55 & 60 & 55 & 54 & 59 \\
& $(100 \%)$ & $(100 \%)$ & $(100 \%)$ & $(100 \%)$ & $(100 \%)$ \\
\hline
\end{tabular}

Com relação à televisão, os dados fornecidos pela Marplan indicam que a porcentagem de indivíduos que assistem televisão é no total superior à dos que escutam rádio. No entanto, neste resultado pesam fortemente os indivíduos das camadas superiores, onde - não seria preciso dizer - a proporção dos que possuem aparelhos de televisão e maior. Entre os grupos de renda inferior (Classe $\mathrm{C}$, na denominação da Marplan), os algarismos referentes às pessoas que assistiam televisão igualam praticamente os das que escutaram rádio.

Tabela 10: “O Sr. assistiu televisão ontem?” (1963)
(30 dias durante um mês)
\begin{tabular}{|l|c|c|c|c|c|}
\hline \multirow{3}{*}{ Sim } & Total & Classe A & Classe B & Classe C & Homens \\
Não & $56 \%$ & $71 \%$ & $67 \%$ & $45 \%$ & $45 \%$ \\
& 44 & 29 & 33 & 55 & 50 \\
$\mathrm{n}=$ & $(100 \%)$ & $(100 \%)$ & $(100 \%)$ & $(100 \%)$ & $(100 \%)$ \\
& 2020 & 200 & 803 & 1017 & 1013 \\
\hline
\end{tabular}

\section{C - Cinema como forma de recreação}

A julgar pelos resultados obtidos entre os trabalhadores da Empresa Automobilística, o costume de ir ao cinema permanece restrito aos setores de classe media para cima. O operário quase não vai a cinema: Apenas $2 \%$ dos entrevistados declararam que vão mais de 4 vezes por mês, enquanto $40 \%$ afirmaram que nunca vão. 
Como não dispomos de mais informações nessa área, podemos apenas supor os diversos fatores que contribuem para afastar o grupo operário de uma forma de lazer bastante difundida entre as camadas superiores da população. O primeiro deles seria de ordem econômica, constituindo o preço dos ingressos uma barreira para as camadas de renda mais baixa. Porem, tal como no caso da leitura de jornais, não nos inclinaríamos a privilegiar demasiadamente este fator.

\begin{tabular}{|l|c|c|c|}
\multicolumn{4}{c}{ Tabela 11: Frequência a cinema } \\
\hline Mais de 4 vezes por mês & Total & Operários & Ferramenteiros \\
4 vezes por mês & $2 \%$ & $3 \%$ & - \\
3 vezes por mês & 8 & 8 & 8 \\
2 vezes por mês & 8 & 8 & 8 \\
Uma vez por mês & 12 & 10 & 17 \\
Muito raramente $\left(^{*}\right)$ & 6 & 8 & - \\
Nunca vai & 24 & 24 & 25 \\
& 40 & 39 & 42 \\
Sem resposta & $(100 \%)$ & $4 \%$ & $(100 \%)$ \\
$\mathrm{n}=$ & & $62 \%$ & $5 \%$ \\
\hline
\end{tabular}

Obs.: Porcentagens extraídas excluindo-se os que não responderam.

Os algarismos acima mostram que, entre os ferramenteiros, que percebem salários bem mais elevados do que os operários comuns, o cinema igualmente não se apresenta como uma forma de recreação importante. De fato, a porcentagem dos que nunca vão, entre ferramenteiros, é ligeiramente superior à dos operários: $42 \%$ e 39\%, respectivamente. $\mathrm{O}$ desinteresse pelo cinema não parece derivar tampouco da dificuldade de leitura dos letreiros, que poderia constituir um empecilho, tendo-se em consideração que parte dos trabalhadores é apenas parcialmente alfabetizada e que a maioria esmagadora das películas projetadas no Brasil são faladas em idioma estrangeiro. Os ferramenteiros constituem precisamente os setores de mais elevado grau de escolaridade e já vimos que também eles não comparecem com mais assiduidade ao cinema. Na verdade, esta forma de divertimento parece não atrair particularmente os trabalhadores industriais. J. Larrue, em pesquisa sobre a

\footnotetext{
* Não souberam precisar a frequência.
}

participação operária nos lazeres de massa, efetuada em Toulouse ${ }^{13}$ afirma que $38 \%$ dos operários nunca vão ao cinema. A participação dos trabalhadores industriais observa a autora, nas firmas de recreação de massa e ainda muito limitada, como indicam igualmente outros dados. Mesmo nos Estados Unidos, onde os meios de comunicação de massas e de lazer mais se difundiram, diferenças acentuadas subsistem entre as diversas camadas sociais. A democratização das oportunidades educacionais e o desaparecimento do analfabetismo não foram suficientes para eliminar as discrepâncias evidenciadas não apenas na natureza da recreação como nas necessidades culturais de cada estrato socioprofissional. ${ }^{14}$

Dificuldades de outra natureza concorrem igualmente para reduzir a frequência ao cinema entre o grupo operário estudado. Geralmente, o operário casado não tem com quem deixar os filhos menores, e assim prefere não ir.

"Quando era só eu e minha mulher, no interior, a gente ia sempre ao cinema. Gosto muito de cinema, mas desde que mudamos para São Paulo nunca mais fui. Não temos com quem deixar as crianças".

A frequência ao cinema está relacionada à idade. Após os 25 anos, o cinema deixa, praticamente, de constituir um tipo de divertimento importante na vida do operário. ${ }^{15}$

Tabela 12: Frequência a cinema e idade

\begin{tabular}{|l|c|c|}
\hline & 18 a 25 anos & 26 anos para mais \\
Vai ao menos uma vez por mês & $63 \%$ & $20 \%$ \\
Vai menos de uma por mês & 37 & 80 \\
$\mathrm{n}=$ & $(100 \%)$ & $(100 \%)$ \\
\hline
\end{tabular}

Foi possível observar, entre os trabalhadores da Empresa Automobilística, uma mudança drástica das atividades recreativas após o

\footnotetext{
${ }^{13}$ Janine LARRUE, "Loisirs ouvriers ET participation sociale", Sociologie du Travail, Paris, janeiro-março, 1963.

${ }^{14}$ Cf. Clyde WHITE, "Social Class Differences in the Uses of Leisures"; e Alfred C. CLARK, "Leisure and Occupational Prestige", in Eric LARRABEE e Rolf MEYERSON, Mass Leisure.

${ }^{15}$ Ao que parece, a afirmação é válida também para outros grupos profissionais. Como nota Dumazedier, "depois dos 2,5 anos, a assistência ao cinema decresce regularmente, qualquer que seja a profissão". Joffre DUMAZEDIER, "Trabajo y Recreación", in: Georges FRIEDMANN e Pierre NAVILLE, Tratado de Sociologia del Trabajo, México, Fendo de Cultura Econômica, 1963, $2^{\circ}$ vol., p. 353.
} 
casamento, mudança que é provavelmente muito mais acentuada do que entre as camadas médias e superiores. Com o matrimônio, e ainda mais, com o nascimento dos filhos, numerosas formas de lazer a que o operário solteiro se entregava são inteiramente abandonadas. Em parte, há a preferência pelas atividades que abrangem o conjunto do grupo familiar e, em parte, há a simples redução do tempo destinado exclusivamente ao lazer $^{16}$, em decorrência das obrigações familiares e das despesas acrescidas.

No grupo investigado, encontramos $77 \%$ de indivíduos casados, sendo de 30 anos a média de idade. Do total de 20 indivíduos solteiros, apenas um estava compreendido entre o grupo de idade de 30 a 35 anos. Por outro lado, entre os trabalhadores de 22 a 25 anos, $57 \%$ já estavam casados.

\begin{tabular}{|c|c|c|}
\hline Idade & Casados & Solteiros \\
\hline 18 a 21 anos & - & $20 \%$ \\
\hline 22 a 25 anos & $17 \%$ & 50 \\
\hline 26 a 30 anos & 19 & 25 \\
\hline 31 a 35 anos & 39 & 5 \\
\hline 36 a40 anos & 17 & - \\
\hline 41 a 45 anos & $\begin{array}{c}8 \\
(100 \%)\end{array}$ & $\begin{array}{c}- \\
(100 \%)\end{array}$ \\
\hline Sem resposta & $2 \%$ & - \\
\hline $\mathrm{n}=$ & 64 & 20 \\
\hline
\end{tabular}

Obs.: Porcentagens extraídas excluindo-se os que não responderam.

Em tais condições, o fim de semana ${ }^{17}$ dos casados gira em torno da família. ${ }^{18}$ Habitualmente, passam todo o dia em casa, visitam parentes,

\footnotetext{
${ }^{16}$ Estamos utilizando o conceito na acepção de Dumazedier: "Lazer é um conjunto de ocupações às quais o indivíduo pode entregar-se de bom grado, seja para repousar, seja para divertir, seja para desenvolver sua informação desinteressada, sua participação social voluntária ou sua livre capacidade criadora depois de ter desempenhado suas obrigações profissionais, familiares e sociais". I. DUMAZEDIER, Vers une Civilisation du Loisir?, Paris, Seuil, 1962, p. 29 (sublinhado por nós).

${ }^{17} \mathrm{O}$ período normal de trabalho (quando a companhia não solicita horas extras ou quando não há diminuição da jornada de trabalho em decorrência de acúmulo de estoques) é de cerca de 9:30 h diárias, tendo os operários o sábado e o domingo livres. Para o almoço, utilizam-se do restaurante da empresa, dispondo para tanto de intervalo de uma hora.

${ }^{18}$ Os resultados da pesquisa entre os trabalhadores de Toulouse oferecem-nos indicações no mesmo sentido: o lazer operário se identifica fortemente com as horas passadas com a família: " $58 \%$ dos chefes das famílias operários tem lazeres principalmente familiares, quer se trate de "ver um pouco as crianças", brincando com elas, olhando seus trabalhos
}

passeiam com os filhos ou vão à missa. ${ }^{19}$ Pequena é a porcentagem dos que se aproveitam do domingo para praticar esporte, assistir a uma partida de futebol ou realizar qualquer outro tipo de atividade recreativa extrafamiliar. Seríamos tentados a dizer que ocorre uma redução das áreas de relações pessoais, aumentando os contactos primários em relação aos secundários.

Tabela 14: "O que o Sr. habitualmente faz aos domingos?” *

Passam todo o dia em casa

Saem com os filhos, visitam parentes

Praticam esportes, vão ao cinema, ao futebol, passeiam

Trabalham fora (bico)

$\mathrm{n}=$

Obs.: Respostas múltiplas; soma de porcentagens superior a $100 \%$.

\begin{tabular}{|c|c|}
\hline Casados & Solteiros \\
$48 \%$ & $7 \%$ \\
25 & - \\
20 & 97 \\
7 & - \\
64 & 20 \\
\hline
\end{tabular}

A vida da maioria desses trabalhadores, geográfica e socialmente, está confinada aos bairros; participam em escala muito reduzida de atividades recreativas ou culturais de massa que se oferecem a outros grupos sociais. Nesse sentido, e interessante observar que os operários praticamente não frequentam o clube esportivo-recreativo da empresa. A grande maioria das famílias e indivíduos que acorrem ao clube, aberto a todos os empregados, e composta por "mensalistas", ou seja, por trabalhadores de escritório ou por supervisores do setor de produção.

Os dados da pesquisa de Cláudio T. Voga, anteriormente referida, também neste aspecto se aproximam dos obtidos na Empresa Automobilística. Apenas $15 \%$ dos operários entrevistados $(n=191)$ afirmaram utilizar o período de folga exclusivamente para atividades recreativas. Quase a metade (49\%) dos trabalhadores aproveitava o fim de semana para trabalhos caseiros. Nota-se, no caso deste grupo operário, que uma parcela de trabalhadores, mais elevada do que entre os da Empresa Automobilística, além do trabalho

escolares, quer se trate de ajudar as esposas nas tarefas domesticas, de fazer pequenos trabalhos manuais ou de efetuar atividades recreativas que sejam compartilhadas com todos". Janine LARRUE, op. cit., p. 63.

${ }^{19}$ Entre os operários, $47 \%$ declararam-se católicos praticantes; $46 \%$ católicos não praticantes e 7\% de outras religiões. Entre os ferramenteiros, a porcentagem de católicos praticantes decresce bastante (30\%); neste grupo, os que afirmaram ser católicos não praticantes perfazem $66 \%$ e, os de outra religião, $4 \%$. E entre os operários sindicalizados que se encontra a maior proporção de católicos não praticantes: $73 \%$. Inversamente, é entre os não sindicalizados que a porcentagem de católicos praticantes é mais elevada: $48 \%$.

* Comparecimento à igreja não foi incluído no quadro. 
normal na fábrica, realizava outro tipo de atividade remunerada aos sábados e domingos (21\%). Ressalte-se, por outro lado, que um número nada desprezível desses operários (42\%) não tinha durante o fim de semana nenhuma atividade de diversão ou de lazer, no sentido em que estamos utilizando a palavra. Em outros termos: não ouviam rádio, não assistiam a programas de televisão, não iam ao cinema ou futebol, não praticavam esportes, enfim, não realizavam nenhuma atividade recreativa, atividade que não fosse uma obrigação ou um dever, mas atividade voluntária e "gratuita", exercida unicamente com vistas à satisfação de necessidades físicas ou psicológicas. Para esses trabalhadores, o lazer não existe: seus momentos de "folga" estão sempre preenchidos por obrigações familiares, por tarefas domesticas, por estudo, por trabalho extra ("bico"), etc.

\section{D - Salário e condições de vida}

De um modo geral, os trabalhadores da Empresa Automobilística recebem salários bem superiores aos níveis médios vigentes na indústria paulista. Esta afirmação é, aliás, válida para o conjunto dos trabalhadores do ramo automobilístico. Instalando-se num prazo de tempo relativamente curto, as empresas deste setor perturbaram o mercado de trabalho. Necessitando elas próprias de mão de obra qualificada e semiqualificada em grande proporção, e provocando, por outro lado, extraordinária expansão das fábricas de autopeças, o desenvolvimento da indústria automobilística multiplicou rapidamente a oferta de empregos no setor metalúrgico, ${ }^{20}$ ao mesmo tempo em que estimulava a elevação geral dos salários.

Nestas condições, entre os operários, a média salarial era, no segundo semestre de 1963, de Cr\$ 60,33; a dos lideres $\operatorname{Cr} \$ 84,18$ e a dos ferramenteiros, $\mathrm{Cr} \$ 104,06$. Note-se que a média salarial dos ferramenteiros é quase o dobro da dos operários. A comparação com os salários percebidos em outros setores da indústria paulista não pode ser feita com exatidão.

\footnotetext{
${ }^{20}$ Em número de empregados, a expansão da Empresa Automobilística foi a seguinte: em 1957, 569; em 1958: 2.053; em 1959: 4.459; em 1960: 6.961; em 1961: 6.874; em 1962: 9.127. Os números de empregados referem-se a junho de cada ano. Dados fornecidos pelo SENAI mostram que o setor metalúrgico, mecânico e de material elétrico foram os que revelaram, no Estado de São Paulo, maior índice de crescimento, em termos da mão de obra empregada. Assim, tendo como base o ano de 1948, o referido setor atingia 310,1 em 1960. Cf. Relatório do Serviço Nacional de Aprendizagem Industrial, São Paulo, 1960.
}

Faltam informações que permitam cotejar os diversos grupos profissionais empregados em diferentes ramos da indústria. Porém, tendo em conta essa lacuna, uma avaliação grosseira das diferenças salariais pode ser efetuada entre os salários vigorantes entre os operários da indústria metalúrgica da Capital e os do grupo estudado. ${ }^{21}$ Segundo informações do Departamento Intersindical de Estatística e Estudos Sócio-Econômicos (DIESE), a média anual dos salários pagos aos operários metalúrgicos de São Paulo (só capital), em 1963, foi de Cr\$28,74. A média dos salários dos operários na Empresa Automobilística seria deste modo, maior que o dobro da encontrada no setor. Contudo, para que não se exagere a diferença, é preciso ter em conta que os dados do DIESE (que tem como fonte as guias do imposto sindical) abrangem trabalhadores braçais, mulheres e menores, o que tende a rebaixar a média, enquanto, na nossa amostra, temos operários adultos e semiqualificados, estando os braçais excluídos. As cifras do quadro seguintes permitirão avaliar com maior precisão as diferenças salariais entre os diversos setores industriais.

No setor de material de transporte é que se observa a maior elevação dos salários reais $(121$ para $1959=100)$. Em diversos ramos, houve diminuição dos salários reais, como por exemplo, no setor gráfico, papel e papelão e, principalmente, no setor das indústrias farmacêuticas e de borracha. No período, o salário real das camadas operárias empregadas no conjunto das indústrias passou de 100, em 1959, para 103 em 1962. Ainda que no ramo metalúrgico a elevação salarial (104 em 1962) tenha ultrapassado a elevação média do parque industrial paulista, esta elevação foi bastante inferior à verificada no setor de transporte que, em 1962, atingiu 121. Mostraremos mais adiante que os trabalhadores da empresa estudada têm muita consciência do fato de terem sido os mais beneficiados, o que afetará suas atitudes e comportamento ante a empresa. ${ }^{21}$ De acordo com os cálculos do Sindicato Nacional de Tratores, Caminhões, Automóveis e
Veículos Similares, a média mensal dos salários dos operários da indústria automobilística no
seu conjunto, em julho de 1964, era de Cr\$114,00, ou seja, quase três vezes o salário mínimo
então vigente (Cr\$ 42,00). Indústria Automobilística Brasileira, novembro de 1964, São Paulo. 
Tabela 15: Estado de São Paulo - Evolução do salário médio na indústria de transformação (Média mensal dos salários) (*)

\begin{tabular}{|c|c|c|c|c|c|}
\hline & \multicolumn{2}{|c|}{$\begin{array}{l}\text { Salário Nominal } \\
(\mathrm{em} \text { Cr\$ })\end{array}$} & \multirow{2}{*}{$\begin{array}{c}\text { Salário Real } \\
\text { (em Cr\$) } \\
1962\end{array}$} & \multirow{2}{*}{$\begin{array}{c}\text { Índice } \\
1959\end{array}$} & \multirow{2}{*}{$\begin{array}{c}\text { Salário } \\
\text { Real } \\
1962\end{array}$} \\
\hline & 1959 & 1962 & & & \\
\hline Total & 77,33 & 226,35 & 79,70 & 100 & 103 \\
\hline Minerais não metálicos & 66,33 & 186,92 & 65,81 & 100 & 99 \\
\hline Metalúrgica & 85,58 & 251,57 & 88,58 & 100 & 104 \\
\hline Mecânica & 91,53 & 251,87 & 88,68 & 100 & 97 \\
\hline Mat. elet. e de comunicação & 87,56 & 223,70 & 78,77 & 100 & 90 \\
\hline Material de transporte & 93,42 & 320,60 & 112,89 & 100 & 121 \\
\hline Madeira & 69,72 & 197,69 & 69,61 & 100 & 100 \\
\hline Mobiliário & 76,78 & 212,64 & 74,87 & 100 & 98 \\
\hline Papel e papelão & 79,93 & 243,49 & 85,73 & 100 & 107 \\
\hline Borracha & 98,91 & 211,68 & 74,53 & 100 & 75 \\
\hline Couros, peles e prod. similares & 66,19 & 209,07 & 73,61 & 100 & 111 \\
\hline Químicos & 91,59 & 255,76 & 90,05 & 100 & 98 \\
\hline Prod. farm. e medicinais & 82,52 & 165,21 & 58,17 & 100 & 70 \\
\hline Prod. de perf. sabões e velas & 66,85 & 210,73 & 74,20 & 100 & 111 \\
\hline Produtos de matéria plástica & 84,54 & 224,19 & 78,94 & 100 & 93 \\
\hline Têxtil & 69,16 & 196,98 & 69,36 & 100 & 100 \\
\hline Vestuário, calç. e artf. de tec. & 66,18 & 185,46 & 65,30 & 100 & 99 \\
\hline Prod. alimentares & 66,57 & 198,80 & 70,00 & 100 & 105 \\
\hline Bebidas & 77,38 & 210,82 & 74,23 & 100 & 96 \\
\hline Fumo & 83,86 & 201,42 & 70,92 & 100 & 85 \\
\hline Editorial e gráfica & 85,52 & 263,50 & 92,78 & 100 & 108 \\
\hline Diversos & 75,65 & 194,68 & 68,54 & 100 & 92 \\
\hline
\end{tabular}

Fonte: 1959 - Serviço Nacional de Recenseamento; 1962 - IBGE, Registro Industrial.

Vê-se que nem um operário ganhava mais de $\mathrm{Cr} \$ 100,00$ e que nem um ferramenteiro ganhava menos de $\mathrm{Cr} \$ 80,00{ }^{22} \mathrm{O}$ salário percebido na empresa, para a grande maioria dos entrevistados, constitui a única fonte de renda, uma vez que apenas $12 \%$ realizavam, fora do horário de trabalho, outra tarefa remunerada.

\footnotetext{
"Inclui operários qualificados, semiqualificados e braçais.

${ }^{22}$ A inflação torna difícil a apreciação dos algarismos acima. Na ocasião da pesquisa, o salário mínimo era de $\mathrm{Cr} \$ 21,00$,
}

Tabela 16: Salário dos trabalhadores

\begin{tabular}{|l|c|c|c|}
\hline \multicolumn{1}{|c|}{ Salários $($ em $\mathrm{Cr} \$$ ) } & Operários & Lideres & Ferramenteiros \\
30 a menos de 40 & $15 \%$ & - & - \\
40 a menos de 50 & 5 & - & - \\
50 a menos de 60 & 24 & - & - \\
60 a menos de 70 & 30 & - & - \\
70 a menos de 80 & 19 & $50 \%$ & $6 \%$ \\
80 a menos de 90 & 5 & 33 & 28 \\
90 a menos de 100 & 2 & 17 & 28 \\
100 a menos de 110 & - & - & 17 \\
110 a menos de 120 & - & - & 11 \\
120 a menos de 130 & - & - & $(100 \%)$ \\
& $(100 \%)$ & $(100 \%)$ & 18 \\
\hline
\end{tabular}

Para a maioria das famílias, a única fonte de renda é constituída pelo salário do "chefe da casa". Entre os casados, somente em 19\% dos casos outra pessoa do grupo familiar exercia alguma atividade remunerada. Tal resultado se deve, em parte, ao fato de o grupo estudado apresentar uma média de idade relativamente baixa. Os filhos ainda não estão em idade de contribuir para o sustento do lar, enquanto a porcentagem de esposas que trabalham é baixa: $13 \%$. Neste particular, não se nota diferença significativa entre os ferramenteiros, de um lado, e operários, de outro. No primeiro caso, a porcentagem é de $16 \%$ e, no segundo, de $12 \%$. Infelizmente, não pudemos explorar melhor essa área, de modo que não temos elementos para medir com mais exatidão as razões desse resultado. É indiscutível que os cuidados com os filhos e os afazeres domésticos constituem poderoso obstáculo para que a esposa, na família operária, trabalhe fora do lar. Além disso, as empresas, amiúde, recusam-se a empregar mulheres casadas. Mas, por outro lado, em entrevistas informais que realizamos, foi possível observar certa resistência, por parte do "chefe da casa", ao trabalho feminino fora do lar. Este é aceito, em última instância, ante a necessidade imperiosa de aumentar a renda doméstica. Estaríamos, pois, ante a persistência de um padrão tradicional, expresso na limitação da atividade feminina ao trabalho doméstico? Ou se trataria de uma tentativa de aparentar status de camadas mais abonadas, de "gente rica", em que a mulher não precisa trabalhar fora? Em algumas famílias em que a mulher trabalhava, alguns entrevistados manifestaram sua oposição. Nestas 
situações, com frequência, era a própria esposa que insistia em manter um emprego remunerado, contrariando a vontade do marido.

"Minha esposa trabalha na Empresa Automobilística. Prefiro que ela não trabalhe, mas ela quer. Gostaria de ter minha mulher me esperando dentro de casa".

"Minha mulher não trabalha fora. Nunca gostei disso, mesmo com minha filha, que trabalha na Empresa Automobilística. Só aceitei que ela trabalhasse lá porque as mulheres trabalham separadas dos homens".

"Antes de casar minha mulher trabalhava. Agora não. Não quero que ela trabalhe, por orgulho".

Tendo em consideração os dados mencionados sobre os níveis salariais dos entrevistados, que possibilidades aquisitivas se lhes oferece o emprego na Empresa Automobilística? A posse da "casa própria" constitui permanente preocupação para os trabalhadores radicados há mais tempo no "Grande São Paulo". Enormes sacrifícios são realizados para obtê-la. Entre os ferramenteiros, $68 \%$ declararam ser proprietários de suas moradias; entre os operários, a porcentagem foi de $46 \%$. Frequentemente, a casa é construída pelo próprio operário nos seus momentos de folga, às vezes, com o auxílio de parentes e amigos numa espécie de "mutirão" urbano. A construção efetua-se lentamente, por etapas. Depois da compra do terreno a prestação, a construção de uma primeira peça, ampliada pouco a pouco, de acordo com os recursos financeiros e o tempo disponível para construí-la. ${ }^{23}$

\footnotetext{
${ }^{23}$ A construção da moradia pelo próprio trabalhador parece generalizada nas camadas inferiores de São Paulo. Referindo-se aos migrantes nordestinos em São Paulo, escreve Eunice Ribeiro Durham: "A casa própria é um ideal extremamente generalizado e tem, certamente, um valor instrumental. A compra de um terreno e a construção de uma casa, em geral por partes e vagarosamente, constitui uma das poucas formas de capitalização ao alcance do trabalhador. A casa é sempre um investimento que pode dar lucro, pela venda ou locação. E, por isso, uma forma de obter certa segurança econômica. Isto é tanto mais verdade porquanto o preço do aluguel ocupa geralmente uma porcentagem importante do orçamento doméstico. Para uma população sujeita a períodos de desemprego, a casa própria garante a satisfação permanente da necessidade fundamental de abrigo e alojamento e, em caso de necessidade, a alimentação pode ser provida através de biscates ou de qualquer ocupação marginal e temporária. A construção de uma casa é também um modo de acumular gradualmente um pequeno capital, e a compra de um terreno a prestação e a construção parcelada, que progrida conforme a disponibilidade do numerário constitui um dos últimos meios de investir algum dinheiro evitando a desvalorização decorrente da inflação". Eunice R. DURHANI, op. cit., p. 177.
}

A participação do grupo operário na economia de consumo de massas pode ser apreciada, ainda que de modo rudimentar, pela posse de objetos e utensílios manufaturados, principalmente aparelhos eletrodomésticos. $\mathrm{Na}$ tabela seguinte, apresentamos a relação dos bens desta natureza encontrados no grupo estudado. ${ }^{24}$

Tabela 17: "Quais desses objetos existem na casa em que o Sr. mora?”

\begin{tabular}{|l|c|c|}
\hline & Operários & Ferramenteiros \\
Rádio & $93 \%$ & $92 \%$ \\
Liquidificador & 45 & 67 \\
Geladeira & 44 & 69 \\
Televisão & 37 & 83 \\
Enceradeira & 33 & 83 \\
Eletrola & 21 & 50 \\
Automóvel e caminhão & 7 & 15 \\
Máquina de lavar roupa & 5 & 8 \\
Aspirador de pó & - & - \\
n= & 62 & 24 \\
\hline
\end{tabular}

Pode-se notar, no que toca à posse de bens manufaturados e de objetos de conforto doméstico, que a distância que separa os operários semiqualificados dos ferramenteiros é bastante grande. Assim, apenas 33\% dos operários possuem enceradeira em comparação com $83 \%$ entre os ferramenteiros; quanto a aparelhos de televisão, as proporções são as seguintes: $37 \%$ entre os primeiros e $83 \%$ entre os segundos. Ao que tudo indica, os ferramenteiros da Empresa Automobilística tem um poder de consumo aproximadamente igual às camadas médias da população. ${ }^{25}$ Apenas no que tange à posse de rádio os operários superam os ferramenteiros.

${ }^{24}$ A pergunta, para este caso, foi formulada da seguinte maneira: "Quais desses objetos existem na casa em que o Sr. mora?", de maneira a abranger também os trabalhadores solteiros, principalmente os que viviam em casa dos pais.

${ }^{25}$ Com relação à posse de aparelhos eletrodomésticos e bens de consumo durável há um levantamento efetuado pela Marplan - Pesquisas de Mercado, em 1964, junto a uma amostra de 200 famílias da Capital de São Paulo. Não saberíamos dizer até que ponto a amostra é representativa do conjunto da população paulistana, inclusive daquelas parcelas que habitam os bairros periféricos mais pobres. No confronto com os resultados desse levantamento, os ferramenteiros da Empresa Automobilística encontram-se em situação de igualdade mas os operários semiqualificados estão em nítida desvantagem. Pelos dados da Marplan, que não abrangem os habitantes do "Grande São Paulo", $87 \%$ das famílias paulistanas possuiriam rádio; $81 \%$ liquidificador; $73 \%$ enceradeira; $40 \%$ eletrola; $28 \%$ automóvel e/ou caminhão; $34 \%$ máquina de lavar roupa; $23 \%$ aspirador de pó. 
Porem, provavelmente, entre esses últimos, a TV substitui o rádio. $\mathrm{Na}$ ausência de informações fidedignas que nos permitam cotejar o poder aquisitivo dos trabalhadores da Empresa Automobilística com outros setores da população de São Paulo, a apresentação dos dados da tabela anterior tem sua importância diminuída.

Obviamente, as diferenças existentes no interior do proletariado não se resumem à posse de bens de consumo domestico. Elas se manifestam em outros aspectos da vida do trabalhador, nas suas atitudes ante a sociedade global, nas perspectivas que se lhe abrem, no projeto que anima e caracteriza seus desejos de participação e de usufruto das vantagens que o "Brasil moderno" pode lhe proporcionar.

\section{MELHORIA DE VIDA E ASCENSÃO SOCIAL}

A fim de ilustrar melhor a separação entre níveis existentes no interior das camadas operárias, reproduzimos trechos de duas entrevistas bastante representativas, realizadas com dois operários da Empresa Automobilística. Apesar de um pouco longas, elas permitirão captar melhor as diferenças observadas. Trata-se de duas entrevistas informais. A exposição é feita segundo as declarações do entrevistado, tendo sido suprimidas apenas as nossas próprias perguntas. A primeira é de um operário nordestino (24 anos), chegado a São Paulo em 1956. Quando adolescente, trabalhou na roça. No momento da entrevista exercia na Empresa Automobilística a função de lubrificador e abastecedor de ônibus e empilhadeira. Seu salário era de aproximadamente Cr\$36,00 por mês (sem desconto). Instrução ate o primeiro ano primário.

Tenho quatro filhos. A casa onde moro é minha mesma. Pago Cr\$ 10,00 de prestação por mês (aproximadamente $28 \%$ do salário). Para comprar esta casa, comprei primeiro o terreno; fiz um barraco, vendi e comprei uma casinha. Depois vendi aquela e comprei esta.

O que me desagrada na Companhia e o horário de trabalho, porque trabalho nos domingos. Fora disso nada me desagrada. Gosto de trabalho que não tem enchimento de saco. Pelo meu Oto não deixo máquina vazia. O que me desagrada é que ganho pouco. Pelo tempo de casa deveria ter um salário mais alto. Não me importo de fazer qualquer serviço. Na minha secção, eu sou uma das pessoas de salário mais baixo. Eu trabalho tanto e o chefe não reconhece o trabalho que faço...
Não sei o que mais me agrada na empresa. Acho que é a comida. Pelo preço, ela é cem por cento. O que mais estranhei quando comecei a trabalhar lá foram os colegas. A gente não conhece direito. Mas gosto da empresa, pretendo ficar sempre lá se escapar dos "cortes" desta semana. ${ }^{26}$ A culpa dos cortes é do governo que está aplicando o golpe deles. O governo quer baixar o custo de vida. Mas não entendo direito, não sei nada de política. Só sei que isso estragou tecla a indústria automobilística. O Sr. já pensou quanta gente parada? Para mim não é vantagem receber indenização. O que é que eu vou fazer com a indenização? Onde vou arrumar emprego? Hoje em dia não dá para trabalhar por conta própria. $\mathrm{O}$ melhor é trabalhar como empregado porque temos um dinheirinho seguro.

Sou sindicalizado. A companhia não gosta, mas a gente que tem família precisa; nós temos tudo no sindicato: dentista, médico, remédio pela metade. A Companhia sabe que sou sindicalizado. São eles que descontam. Pago Cr\$ 0,10 cruzeiros. Escutei dizer que a Companhia não gosta que a gente seja sindicalizado. Só vou ao sindicato quando preciso de passe para ir ao médico. Fora disso não vou.

Nos momentos de folga, faço serviços em casa; a gente tem que se virar, fazer um biscatinho, pegar uma casa para pintar, rebocar. $\mathrm{Na}$ parte da manhã dá para fazer isso (o entrevistado não trabalhava no período da manhã). Chego em casa, depois do trabalho à uma da manhã. As sete levanto para pegar um servicinho, isso quando há. Quando não tenho o que fazer, fico em casa. Em cinema, nunca vou. A última vez, foi há seis anos atrás. Futebol para mim não existe. Nem para escutar pelo rádio dá tempo.

O que eu fiz em sete anos não é qualquer um que faz. Para isso estou fazendo este sacrifício. Para pagar a prestação da casa. Uma televisão só para mais tarde. Agora não dá mesmo, mas eu gostaria porque não levo as crianças ao cinema. Gostaria de fazer um curso. Mas o caso é que minha leitura não dá, e a gente não vai pedir porque eles não vão atender. A parte da eletricidade me interessaria muito. Se houvesse uma escola por aqui, eu iria. Há escola em Santo André, mas o horário não dá. Teria que pedir ao chefe para mudar de horário, mas ele não gostaria. Se houvesse escola na parte da manhã eu deixaria o biscate e iria estudar.

\footnotetext{
${ }^{26}$ No momento da entrevista em consequência de uma crise no setor, a Empresa Automobilística estava demitindo maciçamente. Os "cortes" constituíam a principal preocupação dos operários, mais acentuadamente entre os trabalhadores não qualificados e admitidos recentemente.
} 
Sou católico, mas faz mais de dois anos que não vou à Igreja, desde que fui batizar meu filho. Não há tempo.

Nas eleições votei em branco porque não achei um candidato que me servisse. $\mathrm{O}$ único que agradou foi o Getúlio; naquele tempo a gente ganhava menos, mas tinha mais conforto. Foi ele que deu mais atenção aos trabalhadores. No Jango não sei se votava. Não digo nem que sim nem que não. Se tivesse que escolher entre o Jango e o Lacerda, aí votava no Jango. Entre ele e o Juscelino, votava no Jango. Acho que o J.K. esculhambou o Brasil com essa tal de Brasília.

Quero ficar sempre em São Paulo. Se eu pudesse, trazia meus pais que ficaram lá (no Nordeste). Desde que vim para São Paulo nunca mais voltei. O dinheiro não dá. Mas lá o salário é muito micho. Acho que aqui a gente acostuma com o dinheiro mais alto.

$\mathrm{O}$ que eu gostaria de falar ao $\mathrm{Sr}$. foi que eu fui trabalhar numa padaria; eu abria a padaria às 4 horas da manhã e fechava à meianoite. Dormia 4 a 5 horas por dia. Fiquei neste serviço um ano. Quando foi para mim casar eu tive que trabalhar até o meio-dia e ia casar às 4 horas. No outro dia fui obrigado a ir trabalhar. Depois que casei vi que não dava para ficar lá; os colegas diziam que tinha uma fábrica automobilística que pagava melhor. Na padaria eu ganhava 5 mil por mês. Na Empresa Automobilística ganhava entre 5.500 a 6.000. Gostaria que meu filho fosse advogado. Quero ver se posso pagar seus estudos. Tenho fé em Deus que isso seja possível. As meninas espero que estudem para ser pelo menos professoras.

A segunda entrevista é a de um operário horista que ocupa o cargo de inspetor final da produção. Casado, com um filho, tem curso ginasial completo. Seu salário é de aproximadamente Cr\$ 70,00 mensais. O entrevistado trabalha, desde 1949, como mecânico, especializado em motores. Antes do atual emprego já havia trabalhado numa fábrica de automóveis. Foi também chauffeur de praça. Conhecia desenhos e, para ser admitido na Empresa Automobilística, foi submetido a provas de utilização de instrumentos de precisão (paquímetro, cálibre, etc.).

Sou católico, mas não frequento igreja. Ensino um pouco de religião ao meu filho. Não poria ele em escola religiosa: acho que ele deveria cursar uma escola do governo. Gostaria que ele fosse engenheiro, mas eu não forçaria a escolha da profissão. Mas obrigaria que ele fizesse o colégio. Farei sacrifícios para isso.

Não tive nenhum problema de adaptação à Empresa Automobilística, porque eu já tinha trabalhado cinco anos em outra. Quando houve um "corte" eu estava trabalhando há menos de quatro meses e, apesar disso, fui conservado.

O que mais me desagradaria na Empresa Automobilística seria ser dispensado. Desde que se trabalhe na indústria de automóveis há sempre o perigo de corte. Os cortes tem origem política. A direção da empresa não tem culpa. Não podemos reclamar. Contra quem reclamar? O governo é o culpado porque não soube resolver o problema, não sei se por desinteresse ou incapacidade.

Pretendo sempre continuar trabalhando em mecânica. Recebi uma oferta da Companhia para fazer um curso técnico de motores. A Companhia custearia $50 \%$ do curso. Se apresentar certificado de aproveitamento, a Companhia reembolsaria tudo. Pretendo ficar sempre na Empresa Automobilística, salvo melhor oferta, porque não tenho preocupação com condução, almoço lá mesmo (no restaurante do pessoal de escritório) e, além disso, o salário é mais elevado do que em outras firmas, e o ambiente é muito bom.

Para subir na empresa, o mais importante é a conduta do trabalhador que só vai sendo conhecida com o tempo. É preciso não chegar atrasado. E não há razão para isso porque eles dão condução. Em segundo lugar, é preciso não faltar, não fingir de doente. Neste caso eles dizem: este é malandro. Pode ter capacidade, mas não vai subir. Em terceiro lugar, no caso de aumento de trabalho, é preciso aceitar. Há os que negam no momento em que a firma mais precisa e não querem trabalhar horas extras.

O governo (período João Goulart) não inspira confiança. É uma política de instabilidade. Não consegue impor respeito. O Lacerda eu já vi na televisão. Acho bastante inteligente, de muita coragem, mas toma medidas violentas. Entre o Jango e o Lacerda, eu votaria em branco. Nenhum deles está capacitado. Acho que o Carvalho Pinto é melhor e já demonstrou isso: firmeza, trabalho, honra, capacidade de receber críticas sem alterar o ritmo do trabalho. Votei no José Bonifácio, por causa do Carvalho Pinto. Foi ele quem construiu um Grupo Escolar no bairro onde meu filho estuda.

Leio jornais todos os dias, o Diário e a Folha. Aos domingos leio o Estadão. Vou mais ou menos uma vez por mês ao cinema. Domingo passado também fui ver a exposição de astronáutica no Ibirapuera. À noite, em geral, fico vendo televisão.

Nunca frequentei o sindicato. Aliás, fui duas vezes para nunca mais voltar, porque os dirigentes são semianalfabetos; não sabem o que são leis trabalhistas. Os dirigentes sindicais deveriam ter no mínimo ginásio, ter curso de relações humanas, estudos. O sindicato deveria 
estar a par da situação, evitando greves estúpidas, procurando meios de educar os operários, ensinar o que eles devem falar. Acho a greve um recurso estúpido. Seria um recurso bom se fosse bem dirigida, se os operários fossem bem instruídos, não fazendo algazarras. Cada um de nós deveria cruzar os braços dentro da fábrica, sem fazer bagunça.

A primeira entrevista explicita a situação de um operário parcialmente participante no modo de vida urbano-industrial. Dizemos parcialmente participante porque sua participação se efetua, se assim se pode dizer, apenas ao nível da inserção no sistema de produção industrial na proporção em que o trabalhador torna-se operário, na medida em que integra, como força de trabalho, o processo capitalista. Mas a participação não se efetiva em todos os níveis. Sua participação é como mão de obra, como produtor. É uma participação passiva, que não ultrapassa a esfera da produção. Está integrado enquanto operário ao sistema fabril, mas não à sociedade global enquanto cidadão. Não participa de outras esferas de atividade societária. Não tem atividade recreativa. Sua vida gira em torno do bairro, de relações de vizinhança. Não lê jornais, não ouve rádio, não assiste televisão. Não acompanha os fatos políticos. Não tem críticas com relação ao sindicato, mas este lhe parece importante apenas enquanto organização assistencial. E, para valer-se dos serviços do sindicato, chega a adotar uma atitude que, embora não saiba exatamente, suspeita não ser do agrado da empresa. A distância que o separa, enquanto consumidor, das camadas sociais médias é muito acentuada.

No segundo caso temos um trabalhador que não está apenas ligado ao modo de produção industrial. O grau de formação profissional, o nível mais elevado de escolaridade, permitem-lhe um padrão de consumo que o aproxima das classes médias. Recusa o sindicato porque "os dirigentes são semianalfabetos". Na realidade, não valoriza a organização sindical nem como um instrumento reivindicativo nem como associação assistencial. Nas eleições para o executivo estadual votou em José Bonifácio porque este "era o candidato de Carvalho Pinto", governo de "trabalho, firmeza e honra" que "construiu uma escola no bairro onde meu filho estuda". Os critérios que seleciona para a escolha do candidato de sua preferência são outros. No primeiro caso, o operário simplesmente votou em branco, porque não encontrou o "candidato que lhe servisse". Gostava do Getúlio porque "protegia o trabalhador". No segundo caso, o critério de preferência eleitoral é menos "populista", apelando para elementos moralizantes mais comuns entre as classes médias ("governo de trabalho, firmeza e honra"). A referência à escola no bairro incide num benefício que o atinge enquanto cidadão e não somente enquanto operário ou membro de uma determinada camada social.

Mas, nos dois casos, encontram-se elementos de similitude. Ambos os trabalhadores responsabilizam o governo pela crise na indústria automobilística. Ambos expressam fortes aspirações de que os filhos estudem e prometem esforçar-se para tanto. Ambos estão empenhados na obtenção da casa própria. O primeiro, no momento da entrevista, pagava pesadas prestações mensais e o segundo construiu ele próprio sua residência. Ambos valorizam o emprego na Empresa Automobilística e buscavam seguir algum curso profissional, se bem que o primeiro, ao que tudo indica, poucas possibilidades encontre de lograr essa aspiração. Contudo, no projeto de vida que se dão, há algumas diferenças que advêm das qualificações de cada um deles, ou seja, das aptidões que possuem para obter melhores condições de vida na sociedade urbana, as quais por sua vez determinarão orientações diferentes no comportamento e no grau de aspirações. Note-se que, na primeira entrevista, o operário está orientado primordialmente por aspirações de melhoria de sua condição como operário, enquanto, no segundo caso, o entrevistado esforça-se, principalmente, por ascender socialmente. Aqui não se trata simplesmente de obter maiores salários, elevar o padrão de consumo ou melhorar as condições de trabalho. Concretamente, com o auxílio da própria companhia, visa, mediante o aperfeiçoamento técnico, galgar novas posições na hierarquia da empresa, deixar de ser "horista", assumir novas funções e tarefas que se distanciem daquelas associadas à condição operária. É significativo, nesse sentido, que o entrevistado não almoce no restaurante dos operários, preferindo o dos empregados de escritório. O projeto de ascensão social que o entrevistado se dá, significa tentativa de movimento ascensional na escala de estratificação social, mudança de status. Implica não apenas vagas aspirações de superar o status profissional operário, mas existência de possibilidades individuais mais acentuadas que alicercem e estimulem formas de comportamento consideradas adequadas para a efetivação das aspirações. Ora, essas oportunidades só se apresentam para os trabalhadores mais preparados educacional e profissionalmente.

Neste caso, o trabalhador movido por acentuadas aspirações de ascensão social, dificilmente poderia orientar-se em direção de maior integração à camada operária. $\mathrm{O}$ sindicato é repelido, ainda que o próprio entrevistado possa vir um dia a utilizar-se de seus serviços, na hipótese de 
um conflito individual com a empresa (conselhos e fornecimento de assistência jurídica ante a justiça do Trabalho).

$\mathrm{Na}$ primeira entrevista, o operário busca mais precisamente uma melhoria de vida que não está dirigida para a ascensão na hierarquia social. A ascensão social ele já a realizou quando passou de lavrador a operário. Há um esforço de melhorar o padrão de vida enquanto operário (o entrevistado realiza trabalho extra e gostaria de realizar algum curso técnico). Porém, a ausência de qualificação profissional e o baixo nível de escolaridade não lhe possibilitam muitas chances de progresso (observe-se que o trabalhador tem nítida consciência disso, ainda que localize os obstáculos em seu próprio despreparo e não na estrutura social). Obviamente preferiria deixar de ser operário, ter outra profissão. Porém, trata-se de uma preferência abstrata, que não canaliza nenhum esforço em tal direção. A esperança de melhoria de vida circunscreve-se ao esforço de obter melhor remuneração pelo trabalho e melhores condições de vida no âmbito da condição operária.

As duas entrevistas personalizam dois tipos de mobilidade e os níveis diferenciados de aspirações acarretados pela natureza do processo de industrialização contemporânea numa economia subdesenvolvida. Nas condições de crescimento econômico brasileiro - onde subsistem concomitantemente, de um lado, amplas camadas da população marginalizada e, de outro, carência de mão de obra qualificada e de técnicos especializados possibilidades relativamente amplas de ascensão social se ofereceram de modo oposto no meio urbano: ascensão mediante a integração à classe operária, quando se tratava de migrantes originários das áreas agrícolas e não industrializadas; ascensão mediante o abandono da condição operária $e$ passagem aos estratos médios, quando se tratava de operários qualificados. De um modo geral, ambas as situações contribuem para dificultar a coesão grupal, a emergência de consciência profissional e de ações coletivas.

Os dados obtidos entre o grupo estudado, tanto os referentes às suas ocupações anteriores quanto os que dizem respeito às profissões de seus pais, coincidem com as conclusões da pesquisa de B. Hutchinson sobre a mobilidade social em São Paulo. O aumento numérico da camada operária efetuou-se basicamente mediante o recrutamento de trabalhadores de origem agrícola, de trabalhadores oriundos de famílias operárias ou de imigrantes estrangeiros. De modo geral, os indivíduos pertencentes aos grupos de classe média conservaram ou melhoraram suas posições no impulso desenvolvimentista dos últimos anos. A maioria da população subiu de status, ou, mais precisamente, a proporção dos que ascenderam socialmente superou a dos que desceram. Isso foi possível em decorrência das novas posições que se ofereceram no transcurso do impulso industrial do pós-guerra. Comparando a mobilidade social em São Paulo com a da Inglaterra, escreveu Hutchinson: "Na Grã-Bretanha existe uma tendência de o movimento ser equilibrado. Em outras palavras, o padrão tende para uma troca de posições de status dentro de uma estrutura bastante estável. Em São Paulo, por outro lado, a proporção de indivíduos que ascenderam é maior do que o dobro da porcentagem dos que desceram". (...) "O padrão contrastante, e que em geral se aplica à cidade de São Paulo, resulta de modificações na estrutura de status, em si mesmo consequência do desenvolvimento econômico. As novas posições de status criadas durante o desenvolvimento significam que novas oportunidades para a mobilidade são oferecidas aos ambiciosos; e são oportunidades cuja exploração bem sucedida não depende de um movimento correspondente de outras pessoas. Não existe, em outras palavras, a troca de posições que caracteriza o padrão de mobilidade numa sociedade de estrutura estável, resultando um grande movimento ascendente (ou descendente) que não é contrabalançado por um movimento de iguais dimensões na direção oposta". ${ }^{27}$

Tais características do processo de mobilidade social de São Paulo advêm do modo como se vem efetuando a expansão industrial. O país industrializa-se na época das grandes empresas, sem passar por uma fase de acumulação primitiva de capital. Os setores sociais "independentes" (pequenos proprietários, artesãos e camponeses) foram sempre, social e economicamente, inexpressivos. $\mathrm{O}$ avanço tecnológico, os melhores salários e condições de trabalho, o "progresso", em suma, estiveram ligados à implantação da grande empresa industrial, notadamente ao capital estrangeiro, que trouxe novos padrões de racionalidade administrativa e de organização da produção. Os estratos sociais "independentes" não lograram alcançar, desde o período em que a grande lavoura predominava amplamente, nenhum reconhecimento social. Demais, em termos da remuneração do trabalho, tais atividades nem sempre foram muito gratificadoras. Por essas circunstâncias e como denotam as experiências profissionais concretas dos

${ }^{27}$ Bertran HUTCHINSON, Mobilidade e Trabalho, cap. 9, "Mudanças de Status Social de uma Geração para Outra”, C.B.P.E., Rio de Janeiro, p. 218. 
indivíduos que anteriormente "trabalhavam por conta própria" ou como "empregados", frequentemente a incorporação ao meio operário, através da obtenção do emprego numa grande empresa industrial, tem mais o caráter de ascensão do que do rebaixamento na escala social.

A aspiração de melhoria de vida, intensa entre os trabalhadores estudados, aparenta poder lograr-se mais facilmente por meios individuais do que coletivos. Como veremos adiante, a recusa do sindicato, ou sua utilização apenas para fins assistenciais, não resulta apenas da persistência de padrões tradicionais. $\mathrm{Na}$ realidade, o trabalhador utiliza-se "racionalmente" do sindicato. Retira da instituição o que - nas condições atuais - ela pode dar e o que lhe interessa, o que lhe parece importante. E, em consequência de um conjunto de determinações sociais mais gerais, e em grande parte precisamente isso que o sindicato pode fornecer. As funções a que ele se dispõe correspondem às que o operário espera, isto é, ao projeto que o operário se dá.

É preciso notar - no que tange à explicação da ausência de solidariedade profissional e de padrões coletivos de ação em função da persistência de valores e modos de comportamento tradicionais - que a própria migração já implica, em maior ou menor escala, uma conduta não tradicional. $\mathrm{O}$ trabalhador que recusa as condições de vida do meio rural e se dirige para o ambiente urbano, de algum modo já rompeu ou está em processo de rompimento com o meio de origem. Sempre que a migração for "voluntária", isto e, não forçada por fatores socioeconômicos ou naturais (perda da terra ou seca, por exemplo), a simples aspiração de melhorar de vida, ascender socialmente ou obter melhores oportunidades profissionais traz implícita a adoção de pelo menos um valor típico das sociedades modernas. O trabalhador recusa viver como viveram seus pais e avós. ${ }^{28}$

O desejo de ascensão social, certamente, pode constituir um fator que tende a dificultar a adesão do migrante a movimentos coletivos e estimular a busca de soluções individuais. Contudo, no caso, não se lida somente com indivíduos que aspiram passar a uma categoria social superior mais sim com o comportamento de uma classe composta, em grande parte, por

\footnotetext{
${ }^{28}$ Este aspecto é apresentado por R. Aron como um dos traços que caracterizam a sociedade moderna: "No passado, cada geração achava normal viver como as precedentes; em nossas sociedades, é a vontade de todos de possuir mais e de viver melhor que é considerada normal”. Raymond ARON, La Lutte de Classes, Gallimard, Paris, 1964, p. 23.
}

grupos de trabalhadores que passam a integrá-la com a perspectiva de lograr uma melhoria de vida. O núcleo da questão é, pois, saber como se comportam, não indivíduos considerados isoladamente, mas uma categoria social orientada por tais valores num dado contexto político, social e econômico (política governamental, relações com as demais categorias sociais, possibilidades de expressão e ação política autônoma, vias de acesso e comunicação com o Poder, etc.).

As possibilidades de ascensão estão restringidas pelo sistema e pelas limitações dos próprios indivíduos, limitações de ordem profissional e educacional, entre outras, e das quais os trabalhadores estão conscientes. Por outro lado, as aspirações de ascensão social, na medida em que não são atendidas, tendem a tornar-se centro de frustração e descontentamento. Cumpre verificar porque tais aspirações, quando não preenchidas, não se traduzem no fortalecimento da solidariedade interna do grupo, mesmo sem a emergência de uma consciência negadora do sistema. As aspirações de integração na sociedade industrial e de melhoria de padrão de vida podem bloquear a estruturação de uma consciência revolucionária - semelhante à que apareceu entre o proletariado europeu no século XIX - mas não impedem necessariamente a emergência de atitudes reivindicativas mais agressivas, como mostra o exemplo do movimento operário norte-americano. $\mathrm{O}$ importante, em tais condições, não é apenas a correlação entre o nível de expectativas do proletariado e as possibilidades de satisfação que a ordem industrial the oferece. $\mathrm{O}$ outro elemento essencial para a compreensão do comportamento operário é que diz respeito aos meios. O problema da fraca coesão grupal e do baixo índice de participação nas atividades sindicais do operariado brasileiro pode ser melhor entendido se a análise for de molde a especificar quais os níveis de expectativas e aspirações do grupo operário, as possibilidades de atendimento que a ordem urbano-industrial the oferece, bem como os instrumentos que se apresentam ao trabalhador para lográ-los. Deste ângulo, a questão da continuidade de modos de pensar, agir e sentir herdados do ambiente tradicional e a problemática do comportamento de mobilidade adquirem outra significação e podem ser incorporados numa análise mais inclusiva, a fim de se estabelecerem as conexões com o modo como se vem efetuando a industrialização brasileira, a formação da classe operária, as singularidades do sistema político e administrativo especialmente a atuação do Estado como medidor das relações entre as 
classes e grupos sociais - o papel e alcance dos sindicatos nas condições do subdesenvolvimento brasileiro, etc.

Da perspectiva de um projeto de melhoria de vida, a obtenção de uma colocação na Empresa Automobilística representa a culminação da vida profissional. Trata-se de uma ascensão social para o trabalhador de origem agrícola que recentemente abandonou as atividades na lavoura; de uma melhoria de vida, tanto para o operário industrial que saiu das pequenas cidades do interior em busca de melhores oportunidades em São Paulo quanto para o operário radicado na Capital que simplesmente "trocou de empresa". Em qualquer desses três casos, o trabalhador dirigiu-se para a Empresa Automobilística (como se teria dirigido para qualquer outra empresa deste ramo) em busca fundamentalmente de melhores salários, este fato merece ser salientado para que se compreenda melhor as atitudes que o grupo estudado manifestará com relação à empresa e ao trabalho. Ambos serão interpretados e avaliados basicamente em função do preenchimento da expectativa inicial: ganhar mais, poder subir de cargo.

De modo geral, estamos ante um grupo operário que efetivamente logrou uma elevação de seus padrões de consumo. Seus estratos superiores começam a participar de certos modelos de consumo típicos das sociedades industrializadas. Tal é, claramente, o caso dos ferramenteiros. Apesar disso, convém não nos enganarmos. As possibilidades aquisitivas dos trabalhadores da Empresa Automobilística, no seu conjunto, ainda estão muito longe das que se oferecem para as camadas operárias dos países efetivamente industrializados do Ocidente e, principalmente, aquém das expectativas desenvolvidas pelos modelos de consumo das sociedades modernas. As técnicas e as formas de organização industrial seguem o modelo existente nas sociedades desenvolvidas, mas a escala salarial é determinada tendo em conta as condições de mercado de trabalho nacional. Contudo, o grupo e os trabalhadores da empresa lograram indiscutivelmente ultrapassar o estágio da simples luta pela sobrevivência, na qual se encontra ainda grande parcela das camadas inferiores brasileiras. Procuraremos mostrar que tal situação acarreta forte ambiguidade nas orientações dos operários, nas quais se interpenetram a satisfação com o status atual e o pessimismo com relação ao futuro, a valorização da empresa e a rejeição da condição operária.

O outro ponto importante para a interpretação das orientações de tais trabalhadores que convém repetir é o fato de se tratar de um grupo operário em processo de formação e fortemente estimulado por aspirações de ascensão social ou de melhoria de vida. Em termos da tipologia e das categorias propostas por Touraine e outros sociólogos franceses, o comportamento do grupo pode ser definido como marcado por uma conduta de Mobilidade, ${ }^{29}$ embora no caso não lidemos unicamente com trabalhadores originários da agricultura.

Até aqui a análise incidiu unicamente nas características gerais dos trabalhadores da Empresa Automobilística. O capítulo constitui, destarte, uma sorte de "apresentação" do grupo ao leitor. Procuramos mostrar suas origens socioprofissionais, suas aspirações e expectativas, seu grau de formação escolar e profissional e sua situação enquanto consumidor. No capítulo subsequente procuraremos analisar o grupo de outro ângulo: em suas relações com a empresa.

\begin{abstract}
${ }^{29}$ Touraine distingue três tipos de migrações, determinados a partir dos fatores responsáveis pela migração das áreas rurais e da decisão que acarreta a substituição da atividade agrícola pela industrial. Assim: I) Deslocamento (déplacement), quando o trabalhador agrícola, incorporando-se ao trabalho fabril, não corta efetivamente suas relações com a comunidade de origem. Essa situação ocorreria tipicamente quando da instalação de uma empresa industrial no meio rural. "Existem muitos níveis no interior desse tipo, desde o caso de um camponês que se emprega por seis meses numa barragem, até o do que se instala na cidadezinha próxima, trabalhando numa empresa permanente, mas mantendo contacto regular com a família e a atividade agrícola, participando, em especial, dos grandes trabalhos de verão. Mas em todos esses casos, uma ocasião precisa deu forma a uma intenção, talvez e mesmo provavelmente latente: a iniciativa não partiu do próprio indivíduo"; II) Partida (départ): "O agricultor ou o operário agrícola decide ir trabalhar na fábrica, abandonar a terra, tornar-se operário. O desenraizamento pode ser, segundo as circunstâncias mais ou menos completa mas é sempre querido ou, pelo menos, aceito. Não se trata mais de um deslocamento mas de uma partida"; III) Mobilidade (mobilité): "O indivíduo que abandona seu meio social de origem é dirigido por uma vontade ou uma perspectiva de ascensão. Pode-se objetar que em todos os casos esta perspectiva existe, mas isso seria confundir uma situação econômica com a avaliação que dela faz o autor. Só se pode falar de conduta de mobilidade social quando a vontade de ascensão social comanda o deslocamento". Alain TOURAINE e Orietta RAGAllI, Ouvriers d'Origine Agricole, Paris, Seuil, 1961, pp. 8 e 9. Para a análise da classe operária em formação, cf. Alain TOURAINE e Bernard MOTTEZ, "Classe Obrera y Sociedade Global" (especialmente, pp. 237 a 251, Movilidad Social y Actitudes Obreras"), in: Georges FRIEDMANN e Pierre NAVILLE (ed.), Tratado de Sociologia del Trabajo, México, Fondo de Cultura Economica, 1963.
\end{abstract}




\section{OS TRABALHADORES E A EMPRESA}

A

obtenção de um emprego na Empresa Automobilística coaduna-se com o projeto geral de melhoria de vida ou de ascensão social que orienta o grupo estudado. Para a imensa maioria dos entrevistados a Empresa Automobilística constitui, como indicamos no capítulo precedente, a culminação de sucessivas experiências profissionais. Tanto os operários quanto os ferramenteiros encaminharam-se para a indústria automobilística basicamente em busca de melhores salários e maiores oportunidades profissionais. De um modo geral, o atual emprego não constitui o resultado da impossibilidade de obter colocação em outra fábrica.

Os dois quadros que reproduzimos a seguir dão-nos indicações bastante claras. O primeiro indica os motivos pelos quais os trabalhadores saíram do último emprego (anterior ao atual). O segundo explicita as razões invocadas pelos respondentes para ir trabalhar na Empresa Automobilística. Trata-se de duas perguntas abertas, isto e, em que os entrevistados não deveriam optar por alternativas propostas de antemão. Nota-se, no primeiro quadro, que a maioria dos entrevistados (53\%) saiu do último emprego porque considerava seu salário muito baixo. Uma minoria significativa (26\%) foi forçada a deixar o emprego anterior, quer porque a firma em que trabalhava encontrava-se em dificuldades financeiras, quer porque foi dispensada. Trata-se, pois, de um grupo que não abandonou "voluntariamente" o emprego anterior. Entre os motivos alegados, a demissão, as condições de trabalho ou as relações com a chefia não ocupam papel de destaque. Com efeito, apenas $2 \%$ dos entrevistados declararam que saíram do Ultimo emprego porque as "condições de trabalho eram más" e somente $1 \%$ porque "os chefes eram ruins". Observa-se, ainda, que $12 \%$ abandonaram o emprego precedente especificamente para se dirigirem à Empresa Automobilística.
Tabela 18: "Por que o Sr. saiu do último emprego?"

Os salários eram baixos Motivos Total de respondentes $(\%)$

A firma anterior estava em dificuldade

Para conseguir emprego na Empresa Automobilística Foi dispensado

Para se aperfeiçoar profissionalmente

Viajou para São Paulo

As condições de trabalho eram más

Para trabalhar por conta própria

Os chefes anteriores eram ruins

Trabalhava por conta própria e fracassou

Outros motivos

$\mathrm{n}=$

Sem resposta

Obs. Respostas múltiplas. Soma das porcentagens superior a 100\%. Porcentagens extraídas excluindo-se os que não responderam.

Tabela 19: "Por que o Sr. foi trabalhar na Empresa Automobilística?"

\begin{tabular}{|l|c|}
\hline \multicolumn{1}{|c|}{ Motivos } & Total de respondentes \% \\
Salários mais altos & 58 \\
Melhores oportunidades profissionais & 22 \\
Foi o emprego que encontrou & 18 \\
Firma grande & 13 \\
Bom ambiente de trabalho & 12 \\
Era uma empresa automobilística & 7 \\
Era uma "boa empresa" & 7 \\
Era a empresa mais simpática & 5 \\
Por relações pessoais & 4 \\
Todas as empresas estrangeiras são boas & 1 \\
Outros motivos & 2 \\
n= & 86 \\
Sem resposta & 2 \\
\hline
\end{tabular}

Sem resposta

Obs: Respostas múltiplas: soma das porcentagens superior a 100\%. Porcentagens extraídas excluindo-se os que não responderam.

Há uma relação bastante estreita entre os fatores que levaram os trabalhadores a abandonar o emprego anterior e os que os levaram a procurar emprego na Empresa Automobilística: a busca de melhores salários. Analisando-se mais de perto as demais respostas, nomeadamente, "firma grande", "era uma empresa automobilística", era uma boa empresa,", pode-se dizer que, na verdade, elas abrangem os dois primeiros itens. 
Empresa grande, empresa automobilística, empresa mais simpática, etc., para os trabalhadores, constituem, justamente, sinônimo de "salários mais altos" e "melhores possibilidades profissionais". É também nas grandes companhias que o operário acredita encontrar maiores probabilidades de elevar-se na hierarquia profissional. Por outro lado, ela permite um aperfeiçoamento profissional, uma especialização e a aquisição de um ofício que, amiúde, as pequenas empresas não podem oferecer. Demais, na eventualidade da perda do emprego, o fato de ter trabalhado na indústria automobilística constitui sempre importante recomendação para a obtenção de nova colocação em outra empresa, tanto no que se refere à capacitação profissional stricto sensu quanto no que se refere às outras qualidades sociais (responsabilidade, seriedade, etc.). A Empresa Automobilística é, pois, valorizada tanto do ponto de vista das vantagens imediatas que pode proporcionar quanto do ponto de vista das possibilidades futuras de progresso profissional.

Para a quase totalidade dos respondentes, a companhia preenche amplamente as expectativas que presidiram a procura do emprego. A imensa maioria dos trabalhadores afirmou que a Empresa Automobilística paga salários mais elevados do que as outras indústrias, não tendo havido um só caso em que o entrevistado afirmasse pagar menos

Tabela 20: "De um modo geral, o Sr. acha que a Empresa Automobilística paga..."

\begin{tabular}{|l|c|c|}
\hline & Operários & Ferramenteiros \\
Melhor que as outras indústrias & $80 \%$ & $96 \%$ \\
Melhor que as outras indústrias & $80 \%$ & $96 \%$ \\
Igual às outras indústrias & 16 & 4 \\
Pior do que as outras indústrias & - & - \\
Depende & 2 & - \\
Não sabe & 2 & - \\
& $(100 \%)$ & $(100 \%)$ \\
$\mathrm{n}=$ & 62 & 24 \\
\hline
\end{tabular}

A tabela é bastante elucidativa e dispensa maiores comentários. Os trabalhadores acreditam-se bem pagos, em consideração com os salários prevalecentes na indústria paulista. Salário mais elevado, no entanto, está relacionado mais estreitamente com o ramo industrial em geral do que com a empresa em particular. O ramo industrial, mais do que a companhia, é que se valoriza, ainda que a Empresa Automobilística esteja "bem cotada" no confronto com as demais. Quando a Empresa Automobilística foi posta em comparação com outras do setor, a porcentagem dos que afirmaram que ela pagava melhor baixou consideravelmente. Entre os ferramenteiros apenas 25\% chegaram a afirmar que a Empresa Automobilística pagava salários mais elevados do que as outras do mesmo ramo. Entre os operários comuns, a proporção foi superior: $31 \%$.

Tabela 21: "De um modo geral, em relação às outras indústrias automobilísticas o Sr. acha que a Empresa Automobilística paga..."

\begin{tabular}{|l|c|c|}
\hline & Operários & Ferramenteiros \\
Melhor & $31 \%$ & $25 \%$ \\
Igual & 51 & 67 \\
Pior & 8 & 4 \\
Depende & 2 & - \\
Não sabe & 8 & 4 \\
& $(100 \%)$ & $(100 \%)$ \\
Sem resposta & $2 \%$ & - \\
\hline
\end{tabular}

Obs: Porcentagens extraídas excluindo-se os que não responderam.

Indicações no mesmo sentido são fornecidas por outras perguntas cujas respostas revelam de modo inequívoco a valorização do ramo automotor. Quando indagamos aos entrevistados que tipo de trabalho iriam procurar em primeiro lugar, na hipótese de saírem da Empresa Automobilística, a maioria afirmou que procuraria arranjar emprego em outra indústria do mesmo ramo. Nota-se, na Tabela 22, que a aspiração de continuar trabalhando na indústria automobilística é ligeiramente mais acentuada entre os ferramenteiros do que entre os operários comuns.

A aspiração de trabalhar por conta própria é mais acentuada entre os operários do que entre os ferramenteiros. Isso pode ser explicado pelo fato de estes últimos possuírem uma formação profissional mais completa, receberem salários mais elevados, realizando tarefas mais agradáveis e interessantes. Não estão submetidos a controle de tempo, e o tipo de trabalho que efetuam, ao contrário dos operadores e montadores, é de natureza a despertar maior interesse, escapando da monotonia que envolve as funções de trabalhadores especializados na realização de certas tarefas simples. 
Tabela 22: "Se por acaso o Sr. saísse da Empresa Automobilística que tipo de trabalho o Sr. iria procurar em primeiro lugar?'”

\begin{tabular}{|l|c|c|}
\hline & Operários & Ferramenteiros \\
Procuraria outra indústria automobilística & $64 \%$ & $70 \%$ \\
Tentaria trabalhar por conta própria & 23 & 18 \\
Procuraria qualquer outra indústria & 8 & 8 \\
Outras respostas & 3 & - \\
Não sabe & 2 & 4 \\
& $(100 \%)$ & $(100 \%)$ \\
$\mathrm{n}=$ & 62 & 24 \\
\hline
\end{tabular}

De modo geral, os ferramenteiros constituem o grupo operário mais ajustado ao trabalho fabril. Possuem um status profissional, no interior da empresa, bem mais elevado do que o das demais categorias profissionais, como os montadores, pintores, torneiros, fresadores, etc. Suas relações com os supervisores e engenheiros são de outra natureza. Tem orgulho de sua profissão e não se colocam na situação de humildade que amiúde caracteriza a atitude do operário brasileiro ante os superiores hierárquicos.

As razões de preferência pela indústria automobilística estão relacionadas basicamente a melhores salários e oportunidades para aperfeiçoamento técnico-profissional.

"Já tenho prática no ramo e sei que as indústrias automobilísticas pagam melhor".

"Prefiro a indústria automobilística para seguir um ofício".

"Quero aprender um ofício melhor, que só a indústria automobilística pode oferecer".

A questão da formação profissional, segundo o projeto que anima os operários, adquire extraordinária importância na avaliação do emprego. Para parcelas ponderáveis da mão de obra industrial, desprovidas de nível técnico e educacional, a aquisição de uma profissão está relacionada com a possibilidade de ascender socialmente, de melhorar de vida, de lograr melhor remuneração. Sem uma profissão, sem uma "especialização", o operário continuará integrando a enorme massa dos não qualificados que habitualmente compõem as grandes filas às portas das fábricas do "Grande São Paulo" à procura de emprego. Contudo, dadas às características que envolveram a formação do atual proletariado brasileiro, a maior parte da mão de obra não passa por um estágio de formação técnica previamente à sua integração na produção. A preparação do operário via de regra se efetua exclusivamente durante o próprio trabalho. Daí a preocupação da escolha de um tipo de tarefa e de emprego que favoreça a aquisição de uma especialização.

"Prefiro a indústria automobilística para seguir um ofício".

"Quero aprender um ofício melhor, que só a indústria automobilística pode oferecer".

\section{A AVALIAÇÃo DA EMPRESA}

A valorização do setor automobilístico implica, consequentemente, a valorização da Empresa Automobilística. Contudo, ela não é avaliada positivamente apenas enquanto mais uma companhia operando no ramo da produção de veículos. A direção da empresa realiza sérios esforços para marcar sua individualidade enquanto procura pôr em prática um conjunto de técnicas de relações humanas e de integração do operário. Trata-se de apresentar a empresa como uma grande família, como um todo homogêneo onde, mais do que gradações hierárquicas, existem diferenciações de funções. Essas técnicas são já bastante difundidas e conhecidas para que nos estendamos nessa questão. A Empresa Automobilística, como, aliás, fazem outras empresas modernas, mantém um centro de abastecimento para os empregados, fornece condução, restaurante, etc. Procura, em suma, propiciar a cristalização de um "espírito de empresa". Edita um jornal interno, no qual sempre se encontram exemplos de operários que lograram, mercê de esforço e dedicação, galgar novas posições na hierarquia da companhia. Mais do que isso: empenha- se em demonstrar que procede com retidão e justiça no trato com os empregados. O lema não declarado que preside suas relações e: o operário bom é recompensado; o mau operário, punido". Há, na ideologia da companhia, uma valorização do self-mademan e do trabalho como fonte de êxito pessoal. É talvez esse aspecto que distingue a Empresa Automobilística de outras existentes no Brasil. Ela ultrapassa o paternalismo tradicional dos empregadores nacionais na medida em que divulga a ideologia de um progresso individual acessível a todos e que dependeria basicamente dos esforços de cada um, independentemente da origem social, do grau de instrução for mal, de relações familiares, etc. Assim, possibilidades de ascender na hierarquia da empresa estariam ao alcance do mais simples operário, desde que revele aptidões para tal. Como um elemento, nem sempre manifesto dessa 
ideologia, de um lado, está a valorização do saber prático e, de outro, a repulsa às formas de privilégio de cunho estamental.

Dentro dessa orientação, a relação com os operários ocupa lugar preeminente na política de relação humana da empresa. Com o fito de reduzir as áreas de atrito, ou de reduzir seu alcance, a direção criou uma "Comissão de Relações no Trabalho". A Comissão, orientada por um sociólogo, destinava-se a receber qualquer queixa apresentada pelo operário, quer se trate de reclamações relativas à supervisão, ou às condições de trabalho, promoção, etc., que constituem os tipos principais de críticas expressadas pelos trabalhadores. Quando da formação da Comissão, o presidente da empresa dirigiu carta a cada operário explicando suas finalidades e garantindo expressamente que nenhum empregado seria punido ou prejudicado por apresentar-se ante a Comissão. Esta, por sua vez, sempre procurou evitar quaisquer formas de represálias por parte dos supervisores, alvos de crítica dos subordinados, apesar do risco de atritos com escalões intermediários, que viam nas atividades da Comissão uma redução de sua autoridade e poder de punição. Embora a Comissão não dispusesse de capacidade de decisão, cabendo-lhe apenas encaminhar as queixas e procurar conciliar as partes em litígio, sua existência demonstra o empenho da empresa na criação de condições de trabalho mais amenas e na eliminação de atritos entre operários e chefia. Trata-se, principalmente, de evitar os choques derivados do arbítrio dos supervisores, do uso descabido da autoridade. A Comissão, deste modo, ocuparia o lugar de uma comissão sindical de empresa, adiantando-se com relação a uma das tendências de evolução do sindicalismo nos países industrializados, e desviando as queixas dos trabalhadores do sindicato para a própria companhia.

Os esforços da empresa nesta área não param aqui. Além dos benefícios já mencionados e de outros serviços assistenciais fornecidos aos trabalhadores, faz-se mister salientar outras vantagens, tais como a venda de automóveis aos empregados, em condições facilitadas, a autorização para a utilização de veículos da companhia nos fins de semana (concessão na verdade, que não abrange os operários comuns), cursos técnicos oferecidos aos elementos que mais se destaquem e de cujos conhecimentos especializados a companhia se sinta particularmente necessitada.

Quais os efeitos dessas técnicas de “incorporação do operário à empresa?" Desde logo, deve-se ter em conta que todas as técnicas de relações humanas e integração do operário, de algum modo, necessitam alicerçar-se em benefícios reais oferecidos aos trabalhadores. Alguns atingem a todos, outros limitam-se a algumas categorias. Na proporção em que constituem vantagens concretas são como tais estimadas pelos operários e conjugam-se para criar uma imagem bastante positiva da companhia. Quanto a esse ponto, as entrevistas informais, as palestras que realizamos quando do estágio como operário numa das secções e os resultados dos questionários não deixam margem a dúvida. A Empresa Automobilística goza de elevado prestígio entre seus trabalhadores. Esta afirmação não implica, de modo algum, em negar a existência de conflitos, de queixas e de descontentamentos e nem tampouco em superestimar o sucesso do esquema de relações humanas. Hesitaríamos, nesse sentido, em falar de uma "integração do operário à empresa", se com esse termo se quer significar uma identificação mais estreita cio trabalhador com a empresa, implicando da parte do primeiro uma lealdade relativamente desinteressada, um envolvimento emocional mais profundo, que obscureça a presença dos interesses econômicos em jogo, as diferenças de cargos e posições, criando, enfim, a imagem da companhia como uma comunidade e fazendo com que o operário sinta a empresa como a sua empresa. Ao contrário: tal como se comportam em relação a outras instituições, como o sindicato, e em outras esferas da vida social, os trabalhadores julgam a Empresa Automobilística instrumentalmente, da perspectiva do projeto de melhoria de vida. Acreditam que mais se utilizam dela do que são utilizados. Há uma apreciação notavelmente racional dos motivos que determinam a política de relações humanas da companhia. A Empresa Automobilística, certamente, é considerada uma "boa empresa", que "paga salários mais elevados", que "trata bem os empregados", mas não há crença na sua generosidade gratuita e desinteressada. Os pontos positivos não são avaliados como dádivas, mas como uma compensação de interesses. A empresa paga bem para que os operários trabalhem mais e melhor; com isso a firma tem mais lucro. Seria por interesse próprio que a companhia paga salários mais elevados: logo, não há razão para "gratidão" por parte dos trabalhadores como também não há para se sentirem "explorados". É significativo, nesse sentido, que $86 \%$ dos operários que responderam que a empresa "trata bem seus empregados", quando procuraram explicar o porque do "bom tratamento" tenham utilizado frases como essas: 
"Querem conseguir um bom rendimento no serviço".

"Porque tratando bem, os operários não sairão de lá para irem a outro estabelecimento concorrente".

"Porque precisam do favor do operário, horas extras, etc. Os operários bem tratados não negam esses favores".

"Tratam bem para que os operários trabalhem melhor; e o operário trabalhando melhor dá mais lucro para a companhia".

Ainda que as finalidades lucrativas da direção sejam ressaltadas, o resultado final parece indiscutivelmente favorável aos objetivos e à ideologia da empresa: não haveria incompatibilidade entre os interesses da companhia e os dos empregados, entre o lucro e o salário. E as metas da política empresarial ante os operários são atingidas: trabalhadores satisfeitos, prontos a "prestarem alguns favores" à companhia. Se não ocorre uma identificação profunda com a empresa não é, pois, em virtude da existência, entre os trabalhadores, de uma "consciência de classe", de uma "consciência de explorado", ou da crença de interesses antagônicos, mas sim da fraca identificação com o ambiente fabril e com o meio socioprofissional.

As citações anteriores das entrevistas requerem ainda outro comentário. Nelas, como em outras, não se pode vislumbrar qualquer relacionamento entre os salários e o poder de barganha dos operários. A companhia paga salários mais elevados, "trata bem" os operários em seu próprio interesse; as vantagens foram oferecidas pela empresa $e$ não adquiridas pelos trabalhadores e em nenhum momento são encaradas como uma conquista sindical. Tal como verbalizaram os entrevistados, a empresa "recompensa" os empregados pelo seu esforço, pelo "sacrifício" na realização de um trabalho árduo. A remuneração recebida não aparece, assim, ligada a determinado status profissional, mas à ideia de merecimento, tal como a realização correta das tarefas por parte do empregado não decorre de um dever mas de uma retribuição por tudo de bom que o empregador the oferece.

"É uma das fábricas que está calma. Os operários da Empresa Automobilística são compreensivos e não fazem greves. Como retribuição, são bem tratados".

"Descanso no café; às 9 h30 tem leite; às 2 h30 leite; às 3 horas, café. Enfim, somos bem tratados. Eles dão porque os empregados merecem, porque nós trabalhamos no duro".

"Reconhecem o serviço, e necessitam dos empregados com os empregados necessitam da companhia".

"Porque os operários merecem ser bem tratados. Para trabalhar melhor".
"Eles se interessam pela produção e eles corespondem bem com um operário bom. A gente estando satisfeito corresponde bem com um bom patrão",

A atitude ante a empresa expressa a que os operários mantêm com relação à sociedade global ou ao mundo urbano-industrial. Não se sentem participantes no seu rumo e destino. Não esperam partilhar nenhum grau de responsabilidade pelas grandes decisões concernentes ao desenvolvimento econômico, à democratização da vida política, à orientação do sindicato, etc. Não relacionam as perspectivas individuais com os processos políticos e sociais mais amplos. Como mostraremos mais adiante, valorizam o desenvolvimento econômico na proporção em que novas oportunidades profissionais, novos empregos se oferecerem, mas não se acreditam imbuídos de qualquer papel nesse processo. Utilizam-se dos serviços dos sindicatos na medida em que deles necessitam, que lhes são úteis, mas não concebem nenhuma responsabilidade pela sua manutenção ou pela sua melhoria. ${ }^{1}$ Esse comportamento, a nosso ver, traduz as condições que cercaram a formação da classe, ou seja, a presença maciça de fortes contingentes de trabalhadores de origem agrícola, a rapidez do processo de industrialização, os elevados índices de mobilidade social e a formação recente da classe, sem maior maturidade e sem maior coesão interna. Para o proletariado brasileiro, a sociedade industrial foi algo que encontrou e no interior da qual ainda não soube definir seu papel, não enquanto mão de obra, Obviamente, mas enquanto força social e política, capaz de uma intervenção autônoma e com objetivos próprios. Mais do que uma valorização intensa da industrialização como um processo socioeconômico, há sua aceitação aliada a um esforço de utilização, de aproveitamento de seus efeitos (novos empregos e oportunidades profissionais), que não traz consigo a ideia de que seja possível influir em sua manutenção e orientação. A Empresa Automobilística é encarada desse mesmo ângulo: dos benefícios e vantagens que oferece, os quais, por sua vez, são vistos como um dado, como algo que lhes cabe aceitar ou rejeitar, mas não modificar. A empresa e algo exterior e, malgrado os esforços da direção, não é aceito como "nós", mas como "eles". Os operários esperam da empresa, como esperam do sindicato, do governo e dos políticos. O conteúdo e o grau da expectativa

${ }^{1}$ Observa Juarez Brandão Lopes, referindo-se aos trabalhadores da fábrica que estudou: "O sindicato não é visto como algo feito por eles, mas por outros para eles. Quando mencionam o sindicato, os operários não usam o pronome "nós" mas sim "eles". Op. cit., p. 58 
variam, mas a atitude é a mesma, traduzindo, no fundo, um sentimento de impotência, de fatalismo e de resignação ante processos e eventos cujas origens não conseguem discernir com precisão, cujas causas não podem controlar, mas cujos efeitos são sentidos sem possibilidade de uma resposta em termos grupais. ${ }^{2}$ A Empresa Automobilística é percebida como um outro, rico e poderoso, com quem não se identificam e ante o qual se sentem indefesos, só podendo defender-se recorrendo a outras entidades igualmente poderosas, como o governo, a Justiça do Trabalho. ${ }^{3}$

${ }^{2}$ No momento em que fazíamos um estágio no setor de usinagem, trabalhando como operário, em consequência da política de restrição ao crédito iniciado pelo governo federal (1963), os estoques passaram a se acumular, e a Empresa Automobilística - como fizeram outras do mesmo ramo - decidiu diminuir a produção e despedir parte dos empregados. Não nos foi possível saber exatamente quantos operários foram dispensados. Num dia, segundo ouvimos de um funcionário categorizado, foram dispensados 500 horistas. Na divisão em que estagiávamos, foram despedidos $30 \%$ do pessoal. As dispensas, o "facão" na gíria dos operários, constituía a preocupação de todos e era o tema de todas as conversas. Os trabalhadores notavam que os estoques se acumulavam e, ainda que nada houvesse sido comunicado pela direção, sabiam que naquela semana haveria cortes. Todos estavam visivelmente nervosos. Soubemos que a taxa de acidentes aumentara, ao procurarem os operários "dar mais produção". A companhia dispensava inicialmente os recém-admitidos, os setores menos qualificados, os solteiros e os considerados "maus empregados". Cabia ao mestre avisar pessoalmente os trabalhadores dispensados, o que era feito logo cedo, antes do início do trabalho. Não houve qualquer protesto dos operários. O "facão" era aceito com resignação. Os que ficavam lamentavam os colegas "cortados", dando-se por felizes por não estarem na mesma situação. Não ouvimos críticas à empresa. O responsável era o governo. Não houve igualmente menção a qualquer hipotética intervenção ou papel do sindicato, com relação às dispensas em particular, e ao desemprego em geral. Pudemos conversar mais demoradamente com um operário (forjador) que fora despedido. Tinha um mês de casa. Informou que já trabalhara em outra indústria automobilística. Estava irritado porque feira "cortado" e só o soubera pela manhã: "Deviam ter me avisado ontem; me fizeram vir até aqui, pôr o macacão para depois me dizerem que eu tinha sido dispensado". Disse que não se preocupava muito com a dispensa porque "tenho um parente, que é dono de uma oficina. Posso me arranjar por lá até conseguir outro emprego". Explicou que o "governo tem razão (cortando o crédito). É preciso fazer isso mesmo para arrumar as finanças do país. Vem muita gente para a cidade e depois não há mais emprego. Assim essa gente volta para $o$ campo, para cultivar a terra". Em seguida cri- ticou os colegas da Empresa Automobilística. "O pessoal aqui não quer saber de nada. Na outra companhia (de automóveis) o sindicato $e$ mais ativo; esta- mos ligados ao sindicato de metalúrgicos de $\mathrm{S}$. Paulo, que é mais forte e bem organizado do que os do ABC".

3 Às vezes, o "outro" poderoso pode ser a própria diretoria da companhia, que protegeria o operário contra a prepotência e as injustiças dos escalóes intermediários, sobretudo dos mestres e contramestres, contra os quais se dirigem as principais críticas dos operários. "Eles
Tendo-se em conta essas características dos trabalhadores estudados, compreende-se, de um lado, a dificuldade da empresa para lograr uma efetiva "integração" do operário e de outro, a impossibilidade da cristalização de uma consciência de classe, mesmo de uma "consciência corporativista" como ocorreu, por exemplo, entre o proletariado inglês. ${ }^{4}$ Cumpre ter presente que lidamos com operários que estão empenhados em melhorar de vida por meios individuais, sendo o atual emprego, sobretudo um meio para $\mathrm{o}$ atingimento de tal desideratum.

As considerações anteriores não excluem, de um lado, que alguns trabalhadores, principalmente os que não estão diretamente ligados à produção, manifestem estreita integração com os objetivos da empresa, concebendo-a como se fosse uma grande família ("Lá sou tratado como um filho"; "A Empresa Automobilística e minha segunda mãe") e não excluem, por outro lado, os amplamente descontentes ("Aquilo lá e um verdadeiro quartel").

A avaliação que os trabalhadores fazem da Empresa Automobilística foi investigada de diversos modos. A série de tabelas que transcrevemos a seguir permitirá analisá-la com maior rigor, pondo em relevo as discrepâncias notadas entre os operários e ferramenteiros, entre os setores mais urbanizados e os chegados recentemente à capital, etc.

(sic) não podem tratar mal, porque os operários podem reclamar. Fiz uma reclamação na Segurança quando o supervisor me maltratou. Mas "gente grande" da companhia me aconselhou a esquecer a queixa". Neste contexto é que se insere a "Comissão de Relações de Trabalho", substituindo o sindicato (na presente situação, possivelmente com mais eficácia, do ponto de vista imediato e individual do em- pregado), e efetuando um tipo de "paternalismo moderno" bastante adequado às expectativas do trabalhador brasileiro.

${ }^{4} \mathrm{P}$. Anderson em análise sobre o movimento operário inglês distingue uma consciência de classe "hegemônica" e outra "corporativista": "Se uma classe hegemônica pode ser definida como impondo seus próprios objetivos e suas próprias perspectivas à sociedade no seu conjunto, uma classe corporatista, ao contrário, é a que persegue seus próprios objetivos no interior de uma totalidade social cuja determinação global se situa fora dela. Uma classe hegemônica procura transformar a sociedade à sua imagem, reestruturando o sistema econômico, as instituições políticas, os valores culturais desta sociedade, todo seu "modo de inserção" no mundo. Uma classe corporatista procura se defender e melhorar sua própria situação no interior de uma ordem social aceita tal como é. Desde a metade do século XIX, a classe operária inglesa é essencialmente caracterizada pelo divórcio completo entre, de um lado, uma consciência pronunciada de sua própria identidade e, de outro, por uma incapacidade permanente de propor e impor objetivos ao conjunto da sociedade. Perry ANDERSON, "Les Origines de la Crise Presente", Les Temps Modernes, Paris, agostosetembro de 1964, pp. 425 e 426. Sublinhado no original. 
Tabela 23: "O Sr. pretende trabalhar sempre na Empresa Automobilística?"

\begin{tabular}{|l|c|c|}
\hline & Operários & Ferramenteiros \\
Sim & $89 \%$ & $80 \%$ \\
Não & 8 & 8 \\
Depende & 3 & 12 \\
& $(100 \%)$ & $(100 \%)$ \\
Sem resposta & $2 \%$ & - \\
$\mathrm{n}=$ & 62 & 24 \\
\hline
\end{tabular}

Obs: Porcentagens extraídas excluindo-se os que não responderam.

Observe-se que mais de dois terços dos entrevistados, entre operários e ferramenteiros, gostariam de continuar trabalhando na Empresa Automobilística. Este desejo é mais acentuado entre os trabalhadores comuns do que entre os setores mais qualificados. Atentese para o fato de que, entre estes últimos, $12 \%$ responderam "depende". As respostas à pergunta seguinte (destinada a investigar melhor essa área) dão indicações no mesmo sentido. Indagou-se dos entrevistados se sairiam da Empresa Automobilística na hipótese de que pudessem ganhar, em outra companhia, $20 \%$ a mais do que percebiam na ocasião. A pergunta visava medir, ainda que grosseiramente, em que proporção o salário contribuía para a fixação no emprego e para a avaliação positiva que os trabalhadores faziam da Empresa Automobilística. Grosso modo, dois terços dos entrevistados prefeririam continuar no emprego atual. Aqui também os operários comuns externaram, mais acentuadamente do que os ferramenteiros, o desejo de continuar trabalhando na Empresa Automobilística (76\% contra 67\%). Demais, enquanto $25 \%$ dos ferramenteiros responderam "depende" apenas $7 \%$ dos operários responderam do mesmo modo. Na Tabela 24 estão as respostas dos operários que já tinham trabalhado na roça (Agric.) e as dos que nunca o fizeram (Urb.). Os primeiros, mais acentuadamente do que os últimos, não trocariam de companhia por $20 \%$ a mais em seus salários. O grupo que se mostrou mais disposto a mudar de emprego foi o dos operários comuns sem experiência de trabalho agrícola e, inversamente, foi entre os originários da agricultura que se notou maior apego ao emprego na Empresa Automobilística.
Tabela 24: "Se o Sr. pudesse ganhar em outro lugar 20\% a mais do que ganha atualmente na Empresa Automobilística, o Sr. mudaria de emprego?”

\begin{tabular}{|l|c|c|c|c|}
\hline & \multicolumn{2}{|c|}{ Operários } & Total de & Ferramenteiros \\
Sim & Urbanos & Agrícolas & operários & $8 \%$ \\
Não & $21 \%$ & $9 \%$ & 15 & 67 \\
Depende & 72 & 82 & 76 & 25 \\
Não sabe & 7 & 6 & 7 & - \\
& - & 3 & 2 & $(100 \%)$ \\
Sem resposta & $(100 \%)$ & $(100 \%)$ & $(100 \%)$ & $4 \%$ \\
$\mathrm{n}=$ & 3 & 3 & 3 & 24 \\
\hline
\end{tabular}
Obs.: Porcentagens extraídas excluindo-se os que não responderam.

Os motivos para a permanência na Empresa Automobilística não advêm unicamente das vantagens oferecidas aos seus empregados em comparação com outras indústrias, mas também do fato de que os entrevistados levam em conta, em suas respostas, a indenização por tempo de casa, perdida quando o empregado se demite. Contudo, este aspecto poucas vezes foi mencionado pelos respondentes. Os motivos comumente externados faziam menção a vantagens existentes no emprego atual, como por exemplo:

"Acho arriscado deixar um emprego no qual já me acostumei. Por $20 \%$ a mais não compensa. Aqui posso ser promovido e ganhar mais".

"Aqui estou firme. Mais vale um pássaro na mão do que dois voando".

"Já tenho quatro anos de casa e gosto do serviço. Não sei como iria me sentir num novo emprego".

A quase totalidade das respostas "depende" estava referida ao desconhecimento das condições de trabalho e outras situações relacionadas com o novo emprego imaginário: o chefe poderia ser ruim, o ambiente não ser agradável, etc.

A valorização da Empresa Automobilística pode ainda ser corroborada por outras respostas, tais como as que reproduzimos a seguir:

Tabela 25: "De um modo geral, o Sr. acha que os trabalhadores da Empresa Automobilística são bem tratados por ela?"

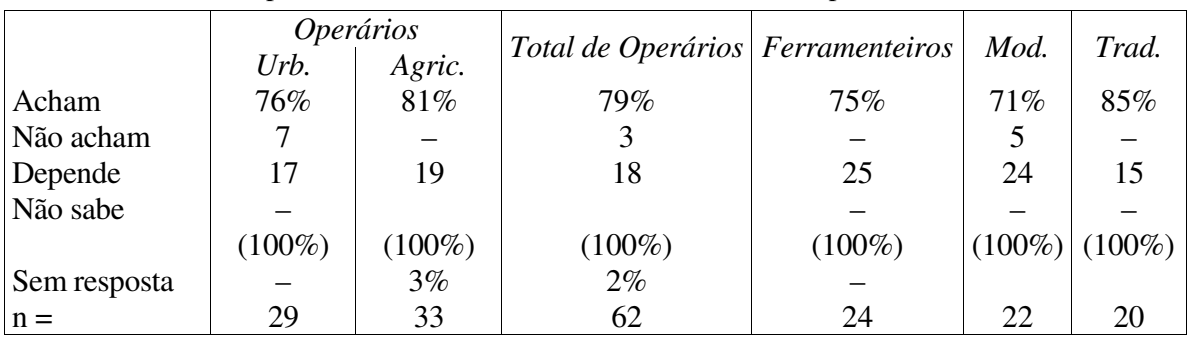


As respostas "depende" geralmente foram do seguinte tipo: "Muitos reclamam dos salários e dos chefes"; "Onde tem muita gente as opiniões são diferentes"; "Existem sempre os descontentes". As demais respostas tinham como pontos de referencia, estimados positiva ou negativamente, salários, condições e ambiente de trabalho. Observe-se, por outro lado, que mais de dois terços dos respondentes consideram que "são bem tratados" pela companhia o que vem, mais uma vez, ao encontro das apreciações anteriores referentes às opiniões dos operários sobre a Empresa Automobilística. Notam-se, igualmente, índices mais elevados de respostas positivas entre os trabalhadores chegados recentemente a São Paulo e entre os operários de origem agrícola. As porcentagens mais altas de respostas "acham" registraram-se entre os Trad. e Agric. (85\% e $81 \%$, respectivamente). A tabela confirma, destarte, tendências observadas nos quadros precedentes. A imagem da Empresa Automobilística como uma "boa empresa" - que paga bons salários, que trata bem os operários e onde os empregados gostariam de continuar trabalhando - é mais acentuada entre os operários do que entre os ferramenteiros, e, quanto aos primeiros, entre os trabalhadores de origem agrícola. A empresa, portanto, é melhor conceituada entre os setores de qualificação profissional inferior e entre os que estão há pouco tempo em São Paulo.

A atitude comparativamente mais crítica dos ferramenteiros não deve ser interpretada como indicativa de maior insatisfação com relação ao trabalho e mesmo em relação à própria empresa. Seu comportamento deve ser analisado à luz de outras variáveis, como seja, o melhor ajustamento ao meio socioprofissional, a experiência mais prolongada no meio urbano-industrial e a formação técnica mais aprimorada. Ocorre que a avaliação do emprego atual é feita tendo como ponto de referência vivências profissionais anteriores cujas condições de trabalho e salário não apresentavam desníveis tão profundos em confronto com as da Empresa Automobilística. Para os operários comuns, em especial para os trabalhadores que dão seus primeiros passos no novo ambiente, o trabalho na Empresa Automobilística significa precisamente a "grande chance" de sua vida profissional ou, mais exatamente, a concretização do projeto de melhorar de vida. Deste ângulo, são mais dependentes da empresa, dependência tanto mais acentuada quanto mais a valorizam e menos possibilidade tem de encontrar colocação equivalente. Entende-se, assim, que os operários de origem agrícola e os recém-chegados de regiões escassamente industrializadas sejam os que apresentam as respostas mais favoráveis à empresa, como evidenciaram os algarismos anteriores. Parece claro que para essa atitude concorrem a comparação com as situações ocupacionais passadas e a apreciação realista das possibilidades que suas habilitações profissionais lhes oferecem para a competição vantajosa no mercado de trabalho.

Essas afirmações são corroboradas pela tabela seguinte, onde se procura averiguar que oportunidades os respondentes pensam ter de encontrar emprego equivalente ao atual. Mais de dois terços dos ferramenteiros afirmaram que encontrariam com facilidade outra posição semelhante à que gozam na Empresa Automobilística, na hipótese de serem despedidos. Essa proporção baixa para $27 \%$ entre os operários de origem agrícola, o que é lógico, dada a carência de mão de obra qualificada e o excesso da não qualificada.

A valorização da Empresa Automobilística está parcialmente condicionada à ideia de que dificilmente se poderia, em outro lugar, ganhar salário equivalente e auferir das mesmas vantagens (bom ambiente de trabalho, restaurante, possibilidades de ascensão, etc.).

Tabela 26: "Se por acaso o Sr. fosse despedido da Empresa Automobilística, o Sr.acha que encontraria um emprego igual com...

\begin{tabular}{|c|c|c|c|c|}
\hline \multirow[b]{3}{*}{ Muita facilidade } & \multicolumn{2}{|c|}{ Operários } & \multirow{3}{*}{$\begin{array}{c}\text { Total de operários } \\
20 \%\end{array}$} & \multirow{2}{*}{ Ferramenteiros } \\
\hline & Urb. & Agríc. & & \\
\hline & $32 \%$ & $9 \%$ & & $37 \%$ \\
\hline Alguma facilidade & 18 & 18 & 18 & 37 \\
\hline Alguma dificuldade & 25 & 46 & 36 & 13 \\
\hline Muita dificuldade & 25 & 21 & 23 & 13 \\
\hline Não sabe responder & - & 6 & 3 & - \\
\hline $\mathrm{n}=$ & 29 & 33 & 62 & 24 \\
\hline Sem resposta & $4 \%$ & & $2 \%$ & - \\
\hline
\end{tabular}

Obs.: Porcentagens extraídas excluindo-se os que não responderam.

Contudo, parece não haver relação entre o grau de valorização da empresa e o de satisfação no trabalho ou de adaptação à condição operária. Os operários que avaliam a Empresa Automobilística de modo mais positivo são, grosso modo, os que denotam maior insatisfação quanto aos salários, ao ambiente de trabalho, à condição operária, em suma. Essas atitudes aparentemente paradoxais explicam-se por um mesmo fator: falta de qualificação profissional e a consequente dificuldade de ajustamento ao meio fabril, ao ambiente socioprofissional. A ausência de formação técnica mais aprimorada acarreta, Obviamente, baixos salários, além da realização de tarefas desagradáveis e desinteressantes, incapazes de provocar rea motivação por parte de seus executantes. O resultado é, de um lado, a 
aspiração mais pronunciada de escapar à condição operária, de abandonar o trabalho fabril e, de outro, a supervalorização de empregos de outra natureza, de situações socioprofissionais mais "nobilitantes".

Tabela 27: O Sr. gostaria de trabalhar em escritório?"

\begin{tabular}{|l|c|c|c|c|c|c|}
\hline & Operários & Ferramenteiros & Urb. & Agríc. & Mod. & Trad. \\
Sim & $51 \%$ & $17 \%$ & $27 \%$ & $63 \%$ & $19 \%$ & $85 \%$ \\
Não & 39 & 70 & 59 & 32 & 71 & 15 \\
Talvez & 10 & 13 & 14 & 5 & 10 & - \\
& $(100 \%)$ & $(100 \%)$ & $(100 \%)$ & $(100 \%)$ & $(100 \%)$ & $(100 \%)$ \\
& 62 & 24 & 49 & 37 & 22 & 90 \\
\hline
\end{tabular}

São precisamente os setores menos qualificados, os trabalhadores de origem agrícola ou os que chegaram recentemente a São Paulo os que revelaram, de modo inequívoco, a preferência mais acentuada pelo trabalho em escritório em comparação com o das oficinas.

Os algarismos dessa tabela exigem uma análise mais demorada. A porcentagem superior de respostas afirmativas é encontrada entre os trabalhadores oriundos de áreas tradicionais (Trad.). Inversamente, são os trabalhadores nascidos na capital e os ferramenteiros os que manifestaram menor disposição de trocar sua atual posição pela de empregados em escritórios. Assim, 85\% dos Trad. disseram preferir trabalhar em escritório contra apenas $17 \%$ de ferramenteiros. Vê-se claramente que os grupos menos qualificados profissionalmente são os que mais acentuadamente aspiram trocar as oficinas pelos escritórios. Mas, em virtude dos baixos níveis de escolaridade, são claramente os que têm as possibilidades mais escassas de concretizar essa aspiração. Destarte, a preferência é puramente abstrata (de acordo, aliás, com os termos em que foi formulada a questão), pois os respondentes são plenamente conscientes de que para tanto lhes faltam preparo e qualificação.

"Sim, gostaria, mas não tenho capacidade, não tenho estudo para isso". "Sim, se a minha capacidade desse, já estaria trabalhando no escritório. Mensalista tem mais vantagem: ganha mais".

A preferência pelo escritório em comparação com a fábrica decorre, como explicitaram os entrevistados, basicamente dos seguintes motivos, entre os quais se torna difícil estabelecer uma ordem de importância: melhores condições e ambiente de trabalho, salário mais elevado, prestígio social e vantagens trabalhistas.
"Gostaria porque teria maior chance de me educar, de aprender a ler e a falar".

"Sim, o trabalho é mais limpo; a gente trabalha menos; se perdesse a hora, só perderia aquela hora e não todo o dia e todo o domingo".

"Gostaria, porque seria um serviço diferente, mais leve e de mais interesse".

"O ordenado é melhor e a gente tem mais descanso".

"Sim, porque o serviço e limpo; o salário é fixo, não tem desconto. O trabalho é limpo, a gente fica limpo".

Trabalhar em escritório é, pois, para os setores profissionais menos qualificados, subir mais um degrau na escala de estratificação social: ganhar mais, não fazer "trabalho sujo", educar-se, ter um "melhor ambiente", para não mencionar as vantagens trabalhistas que o pessoal de escritório como "mensalista" possui sobre os operários ("horistas"). Mas, por outro lado, não indicam essas respostas uma insatisfação mais ou menos profunda com relação à condição operária? Uma apreciação pejorativa do trabalho manual, tido como desagradável, cansativo e "sujo"? Essas atitudes, de parte precisamente dos que têm menos possibilidades de ascender ao setor de escritório, explicam-se pelo fato de que são eles os que percebem os salários mais baixos, realizam as tarefas menos atraentes, às vezes prejudiciais à saúde e fatigantes (como as efetuadas nas secções de pintura e de usinagem dos blocos de motores), amiúde monótonas, em razão de sua natureza repetitiva (como as efetuadas nas secções de montagem), mas sempre incapazes de motivar o operário, de possibilitar uma efetiva satisfação pela sua execução. $^{5}$

As afirmações anteriores podem ser corroboradas por outros dados. $\mathrm{Na}$ tabela seguinte (que reproduzimos mesmo com o risco de enfastiar o

\footnotetext{
5 A rejeição, por parte do operário, de tarefas repetitivas já constitui assunto bastante explorado pela sociologia industrial e do trabalho. Observa-se uma correlação entre a insatisfação no trabalho e a execução de tarefas desse tipo. Por exemplo, pesquisa efetuada entre operários de uma fábrica de automóveis, nos Estados Unidos, mostra que quanto maior o número de operações efetuadas, mais os operários inclinam-se a considerar o seu trabalho interessante: "Entre os operários entrevistados, $85 \%$ afirmaram que preferem realizar diferentes operações; $8 \%$ disseram que preferem trabalhos repetitivos, e os restantes $7 \%$ disseram que não tinham preferências". Charles R. WALKER e Robert H. GUEST, The Man on the Assembly Line, Massachussets, Harvard University Press, EUA, 1952, p. 53. Para uma apreciação mais ampla do assunto, consulte-se Georges FRIEDMANN, Problemas Humanos del Maquinismo Industrial, Buenos Aires, Editorial Sudamerica, 1956 e, do mesmo autor, El Trabajo Desmenuzado, Buenos Aires, Editorial Sudamerica, 1958.
} 
leitor) pode-se distinguir a tendência já apontada em páginas anteriores: $o s$ trabalhadores originários das áreas agrícolas mostram-se mais críticos quanto às condições de trabalho.

Tabela 28: "O que mais lhe desagrada no serviço que o Sr. faz?'

\begin{tabular}{|c|c|c|c|c|}
\hline \multirow[b]{3}{*}{ Nada desagrada } & \multicolumn{2}{|c|}{ Operários } & \multirow{3}{*}{$\begin{array}{c}\text { Total de Operários } \\
60 \%\end{array}$} & \multirow{3}{*}{$\begin{array}{c}\text { Ferramenteiros } \\
57 \%\end{array}$} \\
\hline & $U r b$. & Agric. & & \\
\hline & $62 \%$ & $59 \%$ & & \\
\hline Más condições de trabalho & 17 & 26 & 22 & 9 \\
\hline O regulamento & 3 & & 2 & 9 \\
\hline A chefia & 3 & 6 & 5 & 9 \\
\hline O sistema de promoções & 10 & 6 & 8 & \\
\hline Outras respostas & 3 & 3 & 3 & 22 \\
\hline $\mathrm{n}=$ & 29 & 33 & 62 & 24 \\
\hline Sem resposta & - & $6 \%$ & $3 \%$ & \\
\hline
\end{tabular}

Obs.: Respostas múltiplas. Soma das porcentagens superior a $100 \%$.

Indagou-se dos entrevistados o que lhes desagradava no serviço que perfaziam. A maioria respondeu que "nada desagradava". Talvez possa parecer um pouco surpreendente que a maioria dos entrevistados não tenha apontado nenhum fator de descontentamento no trabalho. É possível, aqui, que muitos respondentes não soubessem explicitar os aspectos que consideram negativo. É possível igualmente que avaliassem o atual serviço em termos de comparação com o que fariam em outras empresas e em função de aspectos desagradáveis inerentes à situação de trabalho fabril e à condição operária. Entretanto, não deixa de ser significativo que a maioria dos entrevistados tenha respondido desse modo, fato indicativo, se não de certa adaptação ao trabalho, pelo menos de uma valorização do emprego e da empresa. Porém, o que nos interessa, e sobre o que se faz mister chamar a atenção, são as diferenças evidenciadas entre os entrevistados. As respostas que apontaram "motivos de desagrado" foram, como seria de se esperar, extremamente variadas. Para fins de análise, as agrupamos nos itens discriminados na tabela seguinte. Observe-se que foi entre os operários de origem agrícola que se registraram as porcentagens mais elevadas de respondentes que indicaram fatores relacionados às condições de trabalho como motivos de descontentamento (26\%). Pelo contrário, foi entre os ferramenteiros que registramos as porcentagens mais baixas: 9\%. Estes últimos são, por outro lado, mais sensíveis aos problemas relacionados aos regulamentos, tópico que entre as demais categorias ocupa lugar secundário.
Na verdade, não houve um só trabalhador de origem agrícola que tivesse apontado questões ligadas aos regulamentos da empresa como motivo de queixa. Cumpre, por fim, ressaltar que grande parte dos entrevistados respondeu à pergunta identificando a tarefa efetuada com a situação geral de emprego na empresa. Alem disso, é preciso ter em conta que os itens abaixo apenas para fins analíticos foram apresentados separadamente e que há, como se pode supor, íntima dependência entre, por exemplo, o regulamento geral da empresa e o sistema de chefia.

Para se compreender o comportamento dos ferramenteiros, preciso relembrar que essa categoria profissional forma um grupo dotado de características bastante singulares e distintas das dos operários comuns. Não só percebem salários mais elevados como gozam de outro status na empresa ${ }^{6}$. A tarefa que efetuam é mais interessante, não estão sujeitos a controle de tempo e movimento e podem experimentar pelo trabalho uma motivação que dificilmente se pode encontrar entre os operários semiqualificados e braçais. Para esses últimos, a tarefa em si não pode oferecer qualquer atrativo, a não ser pela remuneração que percebem e, para a qual, como se verá adiante, são particularmente sensíveis. Demais, na medida em que a atividade profissional pode ser considerada resultado de uma escolha, livremente determinada, é indiscutível que a profissão de ferramenteiro foi mais o fruto de uma escolha do sujeito do que uma imposição das circunstâncias, em contraposição com as categorias menos qualificadas, que se veem constrangidas a agarrar a oportunidade que lhes aparece. Deste modo, o trabalho em escritório não possui, para os ferramenteiros, o atrativo que possui para os grupos menos qualificados. Para os primeiros, ser empregado em escritório não implica, amiúde, nem salários mais elevados, nem melhores condições de trabalho e, nem tampouco, ascensão social.

"Gosto da minha profissão atual e acho que rende mais".

"O serviço de escritório é bom, mas meu voto é estar junto às máquinas". "Trabalhar em escritório, não. Não gosto de ficar parado".

"Estudei comércio, datilografia e taquigrafia, mas não gosto. Prefiro a mecânica".

${ }^{6}$ Os ferramenteiros, por exemplo, recusaram-se a vestir os "macacões utilizados pelos operários comuns, exigindo aventais de serviço, tal como o pessoal de supervisão. Para isso, realizaram a única greve ocorrida na Empresa Automobilística, sendo a reivindicação atendida. $\mathrm{O}$ fato e bem indicativo do esprit de corps existente entre eles e da diferenciação que procuram estabelecer com relação aos demais operários. 
Cumpre ver, também, que a valorização do trabalho que executam está ligada a um interesse geral pelas suas implicações técnicas mais amplas relacionadas aos problemas de mecânica e engenharia. Assim é que muitos ferramenteiros que disseram preferir o trabalho em escritório explicitaram que o prefeririam na hipótese de lidarem com questões técnicas e não burocráticas e administrativas.

"Gostaria de trabalhar no escritório, mas na secção de engenharia".

"Gostaria num escritório técnico, na parte de engenharia de projetos. Na parte administrativa não".

"Se fosse na parte técnica, gostaria. Na parte burocrática não tenho interesse. Gostaria de ser engenheiro ou técnico de ferramentas, para aumentar meus conhecimentos e ganhar mais".

Por outro lado, no que tange à remuneração, foram os ferramenteiros que demonstraram maior satisfação pelos salários que recebiam na Empresa Automobilística. É nesse grupo que se encontra a porcentagem mais elevada de respondentes que afirmaram receber um salário correspondente ao seu trabalho. Os grupos com menos tempo de trabalho fabril, com passagem pela lavoura e chegados recente- mente a São Paulo (Agric. e Trad.) acusaram as porcentagens mais baixas de indivíduos que disseram receber uma remuneração adequada. Pode-se dizer que são, relativamente, os mais descontentes com o salário embora à primeira vista, tendo-se em conta suas origens, fosse de se esperar o contrário. De um modo geral, pelas cifras abaixo, temos a seguinte tendência: os mais críticos quanto à remuneração recebida são: os trabalhadores vindo de áreas tradicionais (Trad.) os sindicalizados e os operários de origem agrícola (Agric.). Entre os primeiros, cerca de um terço afirmou que não recebia um salário adequado.

$\mathrm{O}$ afã de enfatizar as diferenças existentes entre os trabalhadores não nos deve fazer esquecer o fato principal: a maioria dos entrevistados acredita que a Empresa Automobilística lhe paga o salário adequado pelo seu trabalho, embora a proporção de descontentes seja relativamente elevada entre as categorias já apontadas (isto é, entre os menos qualificados). Dois critérios foram quase sempre adotados como ponto de referencia na explicação dos motivos das respostas: I) a comparação com os salários vigentes em outras indústrias e II) o fato de se tratar de uma empresa rica, poderosa. O primeiro motivo era geralmente utilizado pelos que respondiam que a empresa pagava um salário elevado:
"Em outros lugares pagam menos".

"As outras firmas pagam bem menos pelo mesmo serviço".

"Acho que ganhamos bem porque não ganhamos isso em nenhuma outra companhia".

Tabela 29: De um modo geral, na sua opinião, os trabalhadores da Empresa Automobilística acham que recebem o salário que merecem

\begin{tabular}{|c|c|c|c|c|c|c|}
\hline & & & Total de & & & \\
\hline & Urb. & Agric. & operários & Ferramenteiros & Mod. & \\
\hline Acham & $66 \%$ & $58 \%$ & $61 \%$ & $67 \%$ & $68 \%$ & $55 \%$ \\
\hline Não acham & 7 & 27 & 18 & 8 & & \\
\hline Depende & 24 & 15 & 19 & 25 & & \\
\hline Não sabem & 3 & - & 2 & & & \\
\hline & $(100 \%)$ & $(100 \%)$ & $(100 \%)$ & $(100 \%)$ & $(100 \%)$ & $(100 \%)$ \\
\hline $\mathrm{n}=$ & & 33 & 62 & 24 & & \\
\hline Acham & & $\begin{array}{l}U r b . \\
66 \%\end{array}$ & $\begin{array}{c}\text { Agric. } \\
60 \%\end{array}$ & $\begin{array}{c}\text { Sindicalizados } \\
53 \%\end{array}$ & $\begin{array}{r}\text { Não sind } \\
6\end{array}$ & $\begin{array}{l}\text { calizados } \\
\%\end{array}$ \\
\hline Não acham & & 8 & 24 & 17 & & \\
\hline Depende & & 24 & 16 & 30 & & \\
\hline Não sabe & & 2 & - & - & & \\
\hline & & $(100 \%)$ & $(100 \%)$ & $(100 \%)$ & & \\
\hline $\mathrm{n}=$ & & 49 & 37 & 23 & & \\
\hline
\end{tabular}

A segunda razão alegada era o fato de se tratar de uma empresa grande, rica, como - no entender dos entrevistados - deve ser toda indústria automobilística. Sendo assim, deveria remunerar generosamente seus empregados. Este motivo era aventado tanto pelos que diziam que a firma pagava a seus empregados o salário merecido quanto pelos que diziam o contrário. Os entrevistados relacionavam, pois, o salário com o valor da produção e com o lucro da companhia.

"Pagam bem porque têm uma boa produção e dá para pagar o operário". "Fábrica de carro sempre dá lucro".

"Pela produção que há acho que eu deveria ganhar mais".

Cumpre ressaltar que os trabalhadores, com exceção de alguns ferramenteiros, não estabeleciam nenhuma relação entre profissão e salário, qualquer que fosse o sentido da resposta. O salário era avaliado em função da produção e do lucro e, principalmente do esforço físico despendido pelo operário. Raramente mencionavam o cargo ou a função como tendo algum valor em si mesmos e, portanto, devendo receber por eles remuneração correspondente. Assim, não ressaltavam a profissão, mas o trabalho 
efetuado, sem estabelecer distinção entre trabalho qualificado e não qualificado. Não houve nenhuma valorização da profissão enquanto tal, o que é explicável tendo-se em conta o baixo nível de qualificação dos operários. Apenas alguns ferramenteiros, descontentes com seus salários, constituíram exceção nesse quadro quando afirmaram que, dado o valor de suas tarefas, deveriam ganhar mais.

\section{Trabalho e REMUneraÇão}

A magnitude da remuneração salarial constitui, obviamente, em todas as categorias profissionais, fator de primeira grandeza na apreciação do cargo, função e tarefa exercidos. Mas qual exatamente o seu lugar na constelação das múltiplas variáveis que concorrem para a estimação do emprego? Em que medida, por exemplo, "salário mais elevado" é contrabalançado por "melhor ambiente de trabalho" ou por "maiores possibilidades de ascender na companhia"? Não se têm elementos para uma resposta categórica a tais indagações embora se possa dizer que, a partir de dado montante (capaz de satisfazer as necessidades básicas do trabalhador) a reivindicação salarial e outras de natureza econômica passam a ceder lugar a outros tipos de exigências que variam em função da natureza e característica específica das tarefas. Seria desnecessário explicitar que tais "necessidades básicas" estão determinadas socialmente e se diferenciam, no interior de uma mesma sociedade, segundo os vários grupos socioprofissionais, suas aspirações e valores e numerosos outros fatores relacionados às características da cultura nacional.

Pode-se avaliar indiretamente o decréscimo da importância da reivindicação salarial (quando certo padrão de vida acha-se assegurado) pela diminuição relativa das greves puramente econômicas nos países desenvolvidos e pela importância crescente de reivindicações sociais ou político-sociais: garantia contra o desemprego, aposentadoria, controle das condições de trabalho, restrição da autoridade patronal, etc.?

${ }^{7}$ Cf., por exemplo, Arthur ROSS, "Les Relations Professionnelles aux États-Unis dans les Dix Années à Venir", in: Sociologie da Travail, Paris, abril- junho, 1962, e o extensivo estudo de K.G.J.C. KNOWLES, Strikes, a Study in Industrial Conflict, Nova York, Philosophical Library, 952, onde o autor mostra a tendência geral, na Grã-Bretanha, à diminuição das greves operárias, em particular das greves econômicas.
Cumpre, por outro lado, ter presente, no que concerne mais diretamente aos elementos de apreciação do trabalho, que as exigências de cada grupo socioprofissional podem ordenar-se de modo diferente, segundo as circunstâncias do momento, escalonando-se diversamente as reivindicações de cunho econômico ou social, relacionadas, por exemplo, com aspirações de maior prestígio social, maior autonomia profissional, etc. "Tal como as exigências econômicas ou profissionais - escreve J. Frisch-Gauthier - perdem sua virulência sob a ameaça de desemprego, as motivações de origem social ou profissional perdem sua força quando certo nível econômico está ameaçado. Outras necessidades, tais como as necessidades de prestígio social, de recreação ou de desenvolvimento cultural podem ter seu lugar e mesmo um lugar determinado nesta ordem de urgência. Para torná-la mais exata seriam necessários estudos que ainda não foram efetuados nessa perspectiva". ${ }^{8}$

De modo mais preciso, a reivindicação de aumento salarial (ainda que em determinadas ocasiões se ofereça como o ponto nuclear das exigências operárias e dos conflitos industriais) nem sempre emerge como o atributo principal na avaliação do emprego por parte dos trabalhadores. Numa classificação de dez itens para avaliação do emprego efetuada entre operários de 325 fábricas $^{9}$ obteve-se a seguinte ordenação por ordem da importância: I) Estabilidade; II) Boas condições de trabalho; III) Bons companheiros de trabalho; IV) Bons chefes; V) Oportunidade para ascender na empresa; VI) Salários elevados; VII) Oportunidade de usar as próprias ideias; VIII) Oportunidade de aprender um trabalho; IX) Horário bom e X) Trabalho fácil.

Os autores americanos, de um modo geral, tendem a atribuir ponderável importância aos elementos não econômicos que concorrem para a avaliação do emprego. Moore apresenta como dominantes na valorização do emprego: I) a estabilidade; II) boas relações de trabalho e III) status numa sociedade competitiva. ${ }^{10} \mathrm{Na}$ mesma direção, encaminham-se as observações de Schneider que aponta como as principais aspirações do trabalhador: I) A

8 Jacqueline FRISCH-GAUTHIER, "Moral y Satisfacción en el Trabajo", in: Georges FRIEDMANN e Pierre NAVILLE, Tratado de Sociologia del Trabajo, II Vol., p. 153.

${ }^{9}$ Cf. Eugene V. SCHNEIDER, Industrial Sociology, Nova York, McGraw-Hill Book, 1957, p. 178. Dados extraídos da obra de S. WYATT, J. N. LANGDON e F. G. L. STOCK, Fatigue and Boredom in Repetitive Work, Industrial Health Research Board Report 77, Londres, 1937.

${ }_{10}$ Wilbert E. MOORE, Industrial Relations and the Social Order, Nova York, The MacMillan Co., 1956, 2a edição, cap. XI, "The Question of Motives". 
comunidade de objetivos (community goals); II) a segurança econômica e III) boas condições de trabalho. As duas últimas dispensam comentários, mas a primeira requer uma explicitação. Por community goals, entende Schneider "as aspirações do trabalhador a desempenhar certos papeis socialmente respeitados em sua comunidade, de ser um membro efetivamente funcional na comunidade. Por esta razão, o trabalhador deseja garantir um emprego que the apresente como um homem de valor e importância. A fim de obter este tipo de reconhecimento, ele precisa ser reconhecido como tendo um bom emprego numa boa firma, com reputação de fabricar produtos superiores, pagando bons salários e oferecendo boas condições de trabalho"."

É natural que a questão da estabilidade constitua uma das preocupações centrais do proletariado de um país cujo imenso aparelho produtivo tem sido caracterizado por uma capacidade de produção superior à capacidade de consumo. Apesar da recuperação da economia norteamericana ocorrida no início da década dos 60 , o prosseguimento da automação recoloca o problema da garantia do emprego, convertendo-se num dos tópicos principais das discussões entre as organizações sindicais e as empresariais. ${ }^{12}$ Observa E. Chinoy que os trabalhadores norte-americanos da indústria automobilística inclinam-se a identificar a segurança no emprego com "estar subindo na vida". "Desde que há poucas oportunidades para melhorar de ocupação, eles (os operários) voltam suas atenções, de um lado, para a estabilidade (security) e, de outro, para a aquisição de bens materiais, identificando ambos com "subir na vida" (getting ahead). Estabilidade, que sempre foi uma preocupação crucial para os operários da indústria automobilística, em virtude de seu padrão irregular de emprego, é agora identificado com progresso". ${ }^{13}$

Tais características do comportamento do operário americano são explicáveis tendo-se em conta os altos salários vigorantes na indústria dos

\footnotetext{
${ }^{11}$ Eugene V. SCHNEIDER, op. cit., 1957, pp. 175 e 176. Veja-se também o trabalho já clássico de F. J. ROETHLISBERG e W. J. DICKSON: Management and the Worker, Cambridge, Harvard University Press, 1939, Caps. VI e XVIII.

${ }^{12}$ Cf. Jacques DOFNY, "Positions Recentes des Syndicats Americains à l’Égard de l'Automation", Sociologia du Travail, Paris, julho-setembro, 1961.

${ }^{13}$ Ely CHINOY, "The Tradition of Opportunity and the Aspirations of the Automobile Worker", in: Joseph BENSMAN e Bernard ROSENBERG, (eds.), America as a Mass Society, The Free Press of Glencoe, 1963, p. 510. Ver também, de E. CHINOY, Automobile Workers and the American Dream, Boston, Beacon ress, 1955.
}

EUA. Nesse sentido, as observações de J. Frisch-Gauthier parecem particularmente válidas: "Os indivíduos e os grupos tendem igualmente a valorizar as necessidades que tratam de satisfazer no momento presente em detrimento das que as precedem em ordem normal de urgência, mas que já estão satisfeitas. Assim se explicam, provavelmente, as atitudes operárias que comprovam os sociólogos norte-americanos em relação aos aspectos econômicos do trabalho: um poder de compra mais elevado e existente há bastante tempo fez do nível de vida do trabalhador americano uma vantagem adquirida habitual, orientando seus desejos para outras formas de satisfação que vêm atualmente ocupar o primeiro lugar em suas preocupações". ${ }^{14}$

Em troca, na pesquisa francesa de Touraine e Ragazzi, o salário aparecia como a principal reivindicação. No estudo, os autores distinguiram quatro grupos profissionais: I) trabalhadores de origem agrícola, quase todos filhos de lavradores que trabalharam durante certo período na agricultura; II) trabalhadores semiqualificados (O.S. - ouvriers spécialisés) possuindo o mesmo nível profissional que os precedentes; III) operários qualificados, trabalhando há mais tempo na empresa e na indústria de um modo geral; IV) operários-estudantes e estagiários, com alto nível de formação técnicoprofissional, com possibilidades de ascender a postos mais elevados e de remuneração superior. Para fins de comparação com nossos resultados, transcreveremos as respostas dessas categorias à pergunta: "Que é necessário para que um trabalho em geral seja satisfatório?"

Entre os setores mais qualificados (III e IV) o item "interesse pelo trabalho" iguala praticamente o item "salário". Os trabalhadores de origem agrícola e os operários semiqualificados (todos operários especializados, na terminologia francesa) demonstram medíocre interesse pelo tipo de trabalho em comparação com as outras duas categorias profissionais. ${ }^{15}$

\footnotetext{
${ }_{14}^{14}$ Jacqueline FRISCH-GAUTHIER, op. cit., p. 153

${ }^{15}$ A. TOURAINE e O. RAGAllI, op. cit.
} 
Tabela 30: "Que é necessário para que um trabalho em geral seja satisfatório?"

\begin{tabular}{|l|c|c|c|c|}
\hline & $\begin{array}{c}I) \\
\text { Operários de } \\
\text { origem } \\
\text { agrícola }\end{array}$ & $\begin{array}{c}I I) \\
\text { Operários } \\
\text { semiqualificados } \\
\text { Salário }\end{array}$ & $\begin{array}{c}\text { (O.S.) } \\
\text { Operários } \\
\text { qualificados }\end{array}$ & $\begin{array}{c}I V) \\
\text { Operários } \\
\text { estagiários }\end{array}$ \\
Trabalho interessante & $67 \%$ & $76 \%$ & $68 \%$ & $77 \%$ \\
Condições de trabalho & 38 & 46 & 68 & 70 \\
Liberdade no trabalho & 27 & 39 & 32 & 26 \\
Relações com os colegas & 22 & 12 & 13 & 9 \\
Organização do trabalho & 20 & 22 & 21 & 9 \\
Possibilidade de educar-se & 18 & 17 & 8 & 6 \\
Atitude da direção & 13 & 7 & 34 & 44 \\
Estabilidade no emprego & 27 & 34 & 3 & 3 \\
\hline
\end{tabular}

A supervalorização do salário como fonte máxima (ou única) de interesse pelo emprego é, aliás, observada em todos os grupos operários cujas funções não apresentam atrativo em si mesmas, de modo a permitir um envolvimento emocional e intelectual mais profundo por parte dos executantes. "Muitos empregados - escreve Friedmann - comportam-se como se, em troca do abandono de suas potencialidades (capitulação, submissão ao costume), em troca de sua insatisfação profunda, exigissem altos salários, como se, mais ou menos conscientemente, reivindicassem da direção a seguinte transação: "Entendido. Como os senhores da direção me obrigam a trabalhar em semelhante situação, paguem-me bem!"’6 Esta observação, que poderia ser atribuída a todos os setores que perfazem tarefas monótonas, repetitivas e desinteressantes, e especialmente válida no caso de operários, como notaram Touraine e Ragazzi, para os quais o trabalho fabril e julgado em função do projeto de mobilidade, como ocorre entre os operários de origem agrícola. "As atitudes no trabalho são dominadas por objetivos que são, antes de tudo, econômicos. Se reunimos as respostas sobre os elementos de satisfação e sobre os de insatisfação no trabalho atual, parece que os trabalhadores de origem agrícola tem uma sensibilidade particular pelo salário. (...) Este "economismo" corresponde a uma fraca identificação com a situação de trabalho. Sua atividade profissional é mais um emprego do que uma condição". ${ }^{17}$ Os resultados de

${ }^{16}$ Georges FRIEDMANN, "Tendências de Hoy, Perspectivas de Maflana”, in: Tratado de Sociologia del Trabajo, II vol., p. 381.

${ }^{17}$ Op. cit., p. 113. nossa investigação na Empresa Automobilística dão-nos indicações bastante semelhantes às obtidas na pesquisa francesa, principalmente no que tange à valorização extrema do salário entre trabalhadores de migração recente.

Tabela 31: "Numa empresa qualquer, dos itens abaixo, quais os três que o Sr. considera mais importantes do ponto de vista do empregado?"

\begin{tabular}{|c|c|c|c|c|c|}
\hline & Operários & $\%$ & & Ferramenteiros & $\%$ \\
\hline 1 & Chefes justos e honestos & 61 & 1 & Chefes justos e honestos & 54 \\
\hline 2 & Fornecer boa alimentação & 49 & 2 & Treinamto. e aperfeiçoamento técnico & 46 \\
\hline 3 & Possibilidade de subir na empresa & 48 & 2 & Bom ambiente de trabalho & 46 \\
\hline 4 & Pagar salários mais elevados & 39 & 4 & Fornecer boa alimentação & 37 \\
\hline 5 & Fornecer condução & 36 & 4 & Pagar salários mais elevados & 37 \\
\hline 6 & Bom ambiente de trabalho & 36 & 6 & Possibilidade de subir na empresa & 29 \\
\hline 7 & Treinamto. e aperfeiçoamento técnico & 23 & 7 & Fornecer condução & 25 \\
\hline 8 & Cooperativa de consumo & 13 & 8 & Cooperativa de consumo & 12 \\
\hline & Mod. & $\%$ & & Trad. & $\%$ \\
\hline 1 & Chefes justos e honestos & 50 & 1 & Pagar salários mais elevados & 60 \\
\hline 1 & Fornecer boa alimentação & 50 & 2 & Chefes justos e honestos & 55 \\
\hline 3 & Pagar salários mais elevados & 45 & 3 & Possibilidade de subir na empresa & 45 \\
\hline 4 & Fornecer condução & 41 & 4 & Fornecer boa alimentação & 40 \\
\hline 5 & Bom ambiente de trabalho & 32 & 5 & Fornecer condução & 30 \\
\hline 5 & Treinamto. e aperfeiçoamento técnico & 32 & 6 & Bom ambiente de trabalho & 25 \\
\hline 7 & Possibilidade de subir na empresa & 27 & 6 & Treinamto. e aperfeiçoamento técnico & 25 \\
\hline 8 & Cooperativa de consumo & 9 & 8 & Cooperativa de consumo & 20 \\
\hline
\end{tabular}

Obs.: Porcentagens extraídas tendo-se como base o número de informantes.

Nota-se, neste quadro, que as relações com a chefia constituem o ponto crucial para todos os trabalhadores. Compreende-se a significação dessa questão se temos em conta o poder outorgado aos setores de supervisão. Não constitui mera frase de efeito dizer que os mestres e contramestres têm, efetivamente, em suas mãos a carreira dos subordinados, deles dependendo a promoção, a dispensa, etc. E, malgrado a instituição da Comissão de Relações no Trabalho as garantias outorgadas pela alta direção aos empregados que apresentem queixas, amplas possibilidades de represália, aberta ou veladamente, se abrem aos supervisores imediatos, contando 
amiúde com a cobertura dos escalões intermediários e da secção do pessoal. ${ }^{18}$ No entanto, é interessante observar que entre os trabalhadores recémchegados a São Paulo (Trad.) o item "salário" superou ligeiramente o "relações com a chefia". Trata-se, na verdade, do único grupo de entrevistados em que a preocupação com o salário apareceu em primeiro lugar. As diferenças tornam-se mais salientes quando compararmos as atitudes dos ferramenteiros com as dos Trad.. Assim, contra apenas 37\% dos ferramenteiros, $60 \%$ dos Trad. apontaram o salário como o elemento mais importante na apreciação do emprego. Por outro lado, ao contrário dos setores mais qualificados, os de menor qualificação pouca significação atribuíram às possibilidades de aperfeiçoamento técnico e ao ambiente de trabalho. Entre os ferramenteiros esses dois tópicos apareciam em segundo lugar enquanto, entre os Trad., apareciam em sexto, fato indicativo da medíocre atenção que os entrevistados de baixa qualificação profissional concedem aos atributos socioprofissionais que envolvem a condição operária. Lembremos que o item "possibilidade de subir na empresa" ocupou o terceiro lugar entre os Trad. e o sexto entre os ferramenteiros (45\% e $29 \%$, respectivamente), o que sugere aspirações mais pronunciadas de ascensão justamente por parte dos que têm menos possibilidade de realizá-la. Mas, notemos, as questões relacionadas ao treinamento e aperfeiçoamento técnico, entre os Trad. e operários comuns, ocupam o sexto lugar. É que esses trabalhadores destacam apenas os aspectos econômicos da condição operária, de acordo, aliás, com o projeto de melhoria de vida. Destarte, valorizam o salário e as possibilidades de ascensão e, ao contrário dos ferramenteiros, situam em segundo plano os elementos socioprofissionais do trabalho, tais como: aperfeiçoamento profissional, bom ambiente de trabalho, etc. Temos aqui novos indícios que mostram não uma valorização do trabalho fabril e da condição operária, mas simplesmente da empresa e do emprego, considerado

\footnotetext{
${ }^{18}$ Em páginas anteriores fizemos menção aos objetivos que nortearam a criação da Comissão de Relações no Trabalho e das funções que lhe foram atribuídas. Contudo, apesar da declaração expressa do diretor-geral da companhia de que a "diretoria da Empresa Automobilística assegura e garante que não será tolerada nenhuma perseguição aos empregados que apresentem reclamações e as encaminhem por intermédio da Comissão de Relações no Trabalho", e apesar da "propaganda" feita, 34\% dos operários declararam que "nunca tinham ouvido falar na Comissão" (entre os ferramenteiros esta cifra é bem menor: 9\%). Entre os que sabiam da existência da Comissão, $10 \%$ dos operários e $18 \%$ dos ferramenteiros afirmaram que sua criação não trouxera nenhuma vantagem aos empregados. $27 \%$ dos operários e $32 \%$ dos ferramenteiros, por outro lado, não souberam apreciar o papel da Comissão.
}

do ponto de vista salarial. A sensibilidade pelos problemas econômicos, por parte dos entrevistados recém-chegados a São Paulo, é explicável se temos em conta, de um lado, os baixos salários que efetivamente recebem em comparação com as demais categorias e, de outro, o projeto que orientou o deslocamento para a indústria e a cidade.

Chama a atenção, na análise das respostas, a inexistência de qualquer menção à estabilidade no emprego. Certamente, esse tópico não poderia surgir na pergunta anterior, uma vez que os entrevistados foram chamados a optar entre alternativas propostas de antemão, nas quais não havia menção ao problema da estabilidade. No entanto, em outras perguntas abertas, como por exemplo, quando se indagou: "Que aspecto lhe desagrada no atual emprego" ou "Quais as desvantagens que a Empresa Automobilística apresenta com relação a outras companhias?", em nenhum momento foi mencionada a questão da estabilidade. Já vimos que este ponto, nos países desenvolvidos, constitui uma das principais preocupações dos trabalhadores industriais. Dois fatores parecem-nos importantes para que se entenda a aparente despreocupação do operário brasileiro no que toca à estabilidade. O primeiro diz respeito à legislação trabalhista. Esta, como se sabe, obrigava o empregador a indenizar o empregado em caso de dispensa sem justa causa e concedida estabilidade ao operário com mais de 10 anos de casa. Seria ocioso dizer que os empregadores raramente permitiam que os empregados "adquirissem estabilidade", principalmente os "horistas". Ora, a dispensa e o pagamento da correspondente indenização, depois de certo tempo de serviço, já faz parte dos mores das relações industriais no Brasil. O operário sabe que será despedido e a indenização a ser recebida se lhe afigura como um "capital", uma reserva, seja para tentar estabelecer-se por contra própria, seja para assegurar a sobrevivência até conseguir nova colocação. Às vezes, o próprio operário faz por ser despedido, a fim de receber a indenização. Neste contexto, desde que vigore a legislação trabalhista, a dispensa depois de certo tempo de serviço constitui algo já esperado pelo trabalhador brasileiro que, aliás, se caracteriza por alta taxa de rotatividade profissional.

Por outro lado, a expansão industrial do decênio dos cinquenta aumentou a carência de mão de obra qualificada e especializada. O setor superior do proletariado, dotado de certa especialização, pelo menos até 1963, vinha encontrando colocação com alguma facilidade. O problema é mais grave para os trabalhadores braçais, para aqueles que pretendem integrar-se no mercado de trabalho industrial pela primeira vez, para os recém-chegados 
da agricultura. Parece claro aqui que o fenômeno tem conotações diferentes do que para o proletariado industrial de países já desenvolvidos, sobretudo para o dos Estados Unidos que se viu ate a expansão dos últimos anos ante a crônica ameaça da recessão e da desocupação. No caso brasileiro, trata-se de trabalhadores que não conseguem ingressar na economia de mercado, que não conseguem fazer parte do proletariado industrial. No caso de economias desenvolvidas trata-se de operários dotados de certa qualificação que se tornam desempregados em virtude de uma recessão no mercado ou de modificações tecnológicas. Essas observações não significam dizer que os trabalhadores da Empresa Automobilística não valorizem o emprego, mas sim que, pelos motivos expostos, aceitam a eventualidade da dispensa com certo fatalismo, como um ônus a ser suportado por quem teve a chance de trabalhar numa fábrica do ramo.

Estamos agora em condições de sintetizar as observações precedentes. Observa-se, no grupo estudado, uma apreciação bastante positiva da Empresa Automobilística, uma valorização do emprego, da companhia e do ramo industrial que, provavelmente, não se encontre entre trabalhadores de outros setores fabris, mais especialmente nas pequenas empresas e nos setores industriais tradicionais (como alimentação, tecelagem, etc.). Esta valorização repousa em elementos objetivos, ou seja, na comparação entre as vantagens (salários mais elevados, bom ambiente de trabalho, restaurante, condução por conta da companhia, etc.) oferecidas pela Empresa Automobilística e as existentes em outras firmas. A obtenção de emprego na empresa relaciona-se, enquanto objetivo, ao projeto de melhoria de vida ou de ascensão social que anima os trabalhadores, tanto para os recém-chegados a São Paulo, vindos da agricultura ou de pequenas cidades do interior (trabalhadores agrícolas ou operários), quanto para trabalhadores já radicados em São Paulo. A valorização da Empresa Automobilística é mais acentuada entre os operários menos qualificados e entre os que estão efetuando seus primeiros contactos com o sistema de trabalho industrial num grande centro urbano. Contudo, são esses mesmos setores os que, comparativamente, demonstram mais insatisfação quanto aos salários recebidos. Esses resultados, aparentemente paradoxais, podem ser explicados, em primeiro lugar, pelo fato de que são essas categorias profissionais as que percebem efetivamente os mais baixos salários da companhia e que realizam as tarefas mais árduas e desagradáveis. O descontentamento quanto a esses aspectos encontra, pois, fundamentos objetivos para sua emergência. Em segundo lugar, em decorrência de deficiente formação profissional, ou mesmo da ausência de qualquer qualificação, e da inexistência de possibilidades ulteriores de ascensão social, o salário apresenta-se, praticamente, como a única motivação no trabalho para os migrantes que se dirigiram para São Paulo com a intenção precípua de "ganhar mais", de "melhorar de vida". A empresa é um meio, um instrumento para a efetivação do projeto inicial. Ela possibilita ao operário, além da aquisição de uma profissão, de uma especialização, a acumulação de pequenas economias para a aquisição da casa própria, para o momento em que for despedido, momento que ocorrerá fatalmente quando o trabalhador adquirir mais anos de casa se aproximar da estabilidade. Vem dai a importância que assume o salário para as categorias menos qualificadas. Cumpre ganhar mais no menor prazo de tempo uma vez que esses trabalhadores já não veem perspectivas de ascender socialmente. A situação presente é a situação futura para os que não possuem um mínimo de requisitos educacionais que sirva de base para a aquisição de novos conhecimentos especializados e de uma profissão. É desse prisma que se esclarece, ao mesmo tempo, a imagem positiva que esses trabalhadores têm da Empresa Automobilística e a extrema dependência em que dela se encontram para a concretização das aspirações de melhoria de vida.

A valorização da empresa, aliada ao descontentamento quanto às condições de trabalho, à superestimação dos empregos não operários (trabalho em escritório, por exemplo), sugere novamente a fraca identificação com o ambiente social operário, ${ }^{19}$ a procura de um caminho individual e, conjuntamente, um sentimento de impotência ante a empresa. Dai resulta - na medida em que o universo urbano-industrial aparece como um meio, não propriamente hostil, mas estranho - uma atitude fatalista e de resignação, uma aceitação passiva dos eventos e vicissitudes, sobre os quais o trabalhador não consegue influir. Explica-se, destarte, que as ambições de melhorar de vida e a maior sensibilidade com relação ao salário, encontradas entre os setores menos qualificados, não se traduzam numa visão mais crítica da empresa e no reforçamento da coesão grupal.

19 “... quando a incorporação (do trabalhador) à classe operária se relaciona com uma mobilidade ascendente, aparece um 'economicismo' individualista que, ao mesmo tempo, reduz o choque da entrada no meio técnico e a identificação ao meio social do trabalho". A. TOURAINE e B. MOTTEZ, "Clase Obrera y Sociedad Global", op. cit., p. 239 Sublinhado no original. 
Idealmente, manifestam de modo mais acentuado aspirações a novos empregos, que a seus olhos significam considerável ascensão social e passagem a uma camada superior. Essa atitude advém em grande parte de um desajustamento ao meio fabril, de uma percepção mais aguda das diferenças sociais e das distâncias que os separam dos indivíduos das camadas superiores, de uma supervalorização do estilo de vida e dos atributos que envolvem "o mundo dos ricos". Praticamente, sabem que as vias de ascensão social estão barradas e o projeto que se dão e o de melhorar de vida dentro do atual status sócio- profissional. Dessa perspectiva, o emprego na Empresa Automobilística assume importância transcendental. Ante a concorrência de um excedente de mão de obra, da fraqueza das organizações sindicais, os setores operários menos qualificados sentem-se inteiramente inermes ante a empresa, que além de poderosa e capaz de lhes proporcionar uma situação econômica e outras vantagens consideravelmente superiores às que possuíam nos seus lugares de origem e, também, uma situação melhor do que a oferecida pela grande maioria das indústrias de São Paulo.

As tabelas seguintes fornecem novos subsídios para a inteligência dos motivos que levam à avaliação positiva da Empresa Automobilística. Note-se que a proporção dos entrevistados que afirmou que a "situação dos operários melhorou no decurso desses últimos anos" não chega a um terço e que a porcentagem dos que declararam que ela piorou e bastante elevada. ${ }^{20}$

\footnotetext{
${ }^{20} \mathrm{O}$ quadro que reproduzimos no I Capítulo mostrou nos últimos anos (1962 principalmente) uma redução dos salários reais de numerosas categorias profissionais, mas não no setor automobilístico. Outros dados indicam que, no "quinquênio desenvolvimentista", inaugurado em 1955, os salários reais elevaram-se, ainda que em ritmo inferior ao aumento da produtividade. Assim, segundo dados dos inquéritos econômicos do IBGE, reproduzidos pelo Boletim do Departamento Intersindical de Estatística e Estudos Econômicos (DIESE), o salário real na indústria brasileira aumentou de $15 \%$ entre 1955 e 1959, evolução inferior à do aumento da produtividade, que atingiu $37 \%$ no mesmo período. Outros dados, da mesma fonte, concluem igualmente por um aumento dos salários reais. José Albertino RODRIGUES, baseando-se nas contribuições ao IAPI, afirma: "Apesar de algumas variações, comprova-se que o salário real sofreu uma elevação de $38,6 \%$ para os industriários de todo o Brasil e de 44,2\% em São Paulo, de 1940 para 1958". "Padrão de Vida da População Brasileira", Revista de Estudos Sócio-Econômicos, São Paulo, novembro de 1961, ano 1, n. ${ }^{\circ} 3$, p. 45. O mesmo autor, em outro artigo, afirma que o valor real do salário mínimo, em todo o Brasil, cresceu de aproximadamente 100 entre 1951 e 1958. Cf. "Situação Econômico-Social da Classe Trabalhadora no Brasil", Revista de Estudos SócioEconômicos, São Paulo, setembro de 1961, ano 1, n. ${ }^{\circ} 1$.
}

As respostas dos entrevistados expressam, pois, uma opinião negativa da situação geral das camadas assalariadas. Para tanto devem ter concorrido, enquanto fenômeno geral, a aceleração do processo inflacionário e, enquanto fenômeno particular, as dispensas efetuadas pela Empresa Automobilística aproximadamente dois meses antes da aplicação dos questionários, e cuja influência nas respostas não saberíamos informar com precisão.

Tabela 32: "O Sr. acha que, nestes últimos anos, a situação dos operários..."

\begin{tabular}{|l|c|c|c|c|c|c|}
\hline & Total Urb. & Agric. & Operários & Ferramenteiros & Mod. & Trad. \\
Ficou a mesma coisa & $23 \%$ & $8 \%$ & $16 \%$ & $21 \%$ & $19 \%$ & $10 \%$ \\
Piorou & 21 & 35 & 26 & 29 & 29 & 40 \\
Depende & 50 & 52 & 52 & 42 & 52 & 45 \\
& 6 & 5 & 6 & 8 & - & 5 \\
$\mathrm{n}=$ & $(100 \%)$ & $(100 \%)$ & $(100 \%)$ & $(100 \%)$ & $(100 \%)$ & $(100 \%)$ \\
\hline
\end{tabular}

As diferenças entre os diversos grupos não são muito acentuadas. Levando em conta as respostas da tabela seguinte, observa-se, entre os ferramenteiros, uma apreciação mais otimista com relação à situação do proletariado de um modo geral e em relação à sua em particular. Chama a atenção nos algarismos acima, as variações nas respostas dos Agric. e Trad. Esses últimos, via de regra, tendem a expressar de modo mais acentuado as tendências que se configuram mais difusamente entre os primeiros, o que não ocorreu neste caso, sendo os Agric. os mais pessimistas. Mas, antes de se analisar mais demoradamente os algarismos acima, faz-se mister confrontá-los com os dados do quadro seguinte, que dão novos elementos para a avaliação das atitudes do grupo.

Ressalta da comparação dos quadros anteriores que a maior parte dos entrevistados inclina-se a considerar que, enquanto a situação geral da classe piorou, a dele melhorou. Efetivamente, a porcentagem dos que avaliaram negativamente a sua própria situação econômica é bastante pequena. Entre os ferramenteiros, não chegou a haver um só que afirmasse encontrar-se atualmente em situação pior. Assim, os setores mais qualificados tendem a uma visão mais otimista, fato que transparece claramente quando se contrapõem as respostas dos ferramenteiros com a dos operários chegados há pouco a São Paulo (Trad.). O ponto de referência para os julgamentos, positivo ou negativo, é a situação econômica, mais especificamente o confronto entre os reajustamentos salariais e o aumento do custo de vida. 
Tabela 33: "A situação do Sr., nestes últimas anos..."

\begin{tabular}{|l|c|c|c|c|c|c|}
\hline & \multicolumn{2}{|c|}{ Total } & \multirow{2}{*}{ Operários } & Ferramenteiros & Mod. & Trad. \\
Melhorou .. & Urb. & Agric. & & & & \\
Ficou a mesma coisa & $61 \%$ & $44 \%$ & $50 \%$ & $67 \%$ & $64 \%$ & $35 \%$ \\
Piorou & 31 & 48 & 39 & 33 & 27 & 55 \\
Depende & 8 & 8 & 11 & - & 9 & 10 \\
& - & - & - & - & - & - \\
& $(100 \%)$ & $(100 \%)$ & $(100 \%)$ & $(100 \%)$ & $(100 \%)$ & $(100 \%)$ \\
\hline
\end{tabular}

O importante, na análise dos dados de ambas as tabelas, é o resultado do confronto da situação geral do proletariado com a do próprio entrevistado, sendo a primeira analisada em moldes mais pessimistas e a segunda em moldes mais otimistas. Essa comparação reforça, como se percebe, a avaliação positiva da Empresa Automobilística, levando a um empenho maior para conservar o emprego e, ao que tudo faz crer, acarretando uma atitude mais "dócil" ante a companhia. Por outro lado, trata-se de um grupo que tem a consciência de ter melhorado de vida ou ascendido socialmente, de que se encontra numa situação superior à do resto do proletariado e de que, dificilmente, poderia encontrar, fora da Empresa Automobilística, colocação profissional equivalente à atual, fato que se deve ter em conta para que se entenda a sua não participação nos movimentos coletivos da categoria profissional, especialmente nas greves decretadas pelo sindicato. Essa afirmação vale, de um modo geral, para o conjunto do grupo estudado. Convém, contudo, atentar para as discrepâncias notadas entre os respondentes segundo a sua qualificação profissional. Os Trad. são, aqui também, os mais pessimistas. Ora, se temos em conta que esse grupo partiu de regiões onde seu padrão de vida era indiscutivelmente muitas vezes inferior ao que possui atualmente, fica claro que, ao analisar o status atual, não toma unicamente como referência o passado, isto e, suas condições de vida anteriores. Deste modo, e de se pensar que se trata de trabalhadores frustrados socialmente, em virtude de expectativas de êxito incompatíveis com suas aptidões sociais e profissionais para a concorrência no meio citadino. No entanto, é indiscutível que, em termos de seu padrão de vida anterior, realizaram progresso considerável. Esses migrantes são, destarte, vencedores e vencidos. Vencedores na medida em que lograram estabelecer-se num grande centro urbano e empregar-se na indústria moderna. Do prisma da situação anterior, com relação ao passado, são vencedores.
Tabela 34: (Total de operários e ferramenteiros)

$$
\text { "A situação dos operários melhorou por quê?" }
$$$$
\text { Motivos }
$$

Aumentos de salários

Vantagens e benefícios trabalhistas e sociais

Desenvolvimento industrial em geral

Aparecimento da indústria automobilística

Outras respostas

$\mathrm{n}=$

“A situação dos operários ficou a mesma coisa por quê?"

A alta do custo de vida igualou os aumentos de salário

Outras respostas

Não sabe explicar

$\mathrm{n}=$

"A situação dos operários piorou por quê?"

O custo de vida superou os aumentos de salário

Aumentou o desemprego

A política do governo prejudica os operários

Não sabe explicar

$\mathrm{n}=$

Obs.: Respostas múltiplas. Soma das porcentagens superior a 100\%

Mas as possibilidades futuras de sucesso são aleatórias. Os migrantes tomam, pouco a pouco, consciência de que estão ocupando novamente os escalões inferiores da sociedade, que as vias de ascensão social fecharam-se, que de nordestino transformaram-se em "baianos". Sua visão prospectiva é comparativamente mais pessimista, como revelam os seguintes quadros:

Tabela 35: "Que devem fazer os operários para melhorar sua situação?"

\begin{tabular}{|l|c|c|c|c|}
\hline & Operários & Ferramenteiros & Mod. & Trad. \\
Menção a um esforço individual & $48 \%$ & $67 \%$ & $68 \%$ & $25 \%$ \\
Menção a medidas governamentais & 18 & 8 & 14 & 35 \\
Menção a uma ação dos operários & 11 & 4 & 5 & 5 \\
Menção à escolha de bons governantes & 6 & 12 & - & 10 \\
Não há possibilidade & 15 & 8 & 14 & 30 \\
Outras respostas & 10 & 17 & 5 & 20 \\
Não sabe & 2 & 4 & - & - \\
N $=$ & 62 & 24 & 22 & 20 \\
\hline
\end{tabular}

Obs.: Respostas múltiplas. Soma das porcentagens superior a $100 \%$.

O maior número de referências ao esforço individual e encontrado entre os ferramenteiros e Mod. indicando que as categorias operárias mais 
qualificadas e "urbanizadas" inclinam-se, de preferência, a fundar seus esforços nas possibilidades que lhes oferece a formação profissional mais aprimorada. Assim, em contraste com os dois terços de ferramenteiros e Mod. que mencionaram um esforço individual temos apenas $25 \%$ de Trad. Nota-se, por outro lado, que a porcentagem mais elevada de respostas afirmando a impossibilidade de melhoria para os operários foi encontrada entre os entrevistados vindos há pouco de áreas tradicionais: $30 \%$ dos Trad. contra $8 \%$ dos ferramenteiros. $\mathrm{O}$ pessimismo quanto às chances de lograr uma melhoria da situação baseada nas aptidões e realizações pessoais acompanhase da crença e na esperança de uma ação protetora que parta do governo. As porcentagens mais elevadas de menções deste tipo encontram-se justamente entre os migrantes recém-chegados a São Paulo. O trabalhador, cético com relação às suas possibilidades individuais, entrega sua sorte às "medidas favoráveis aos trabalhadores" vindas "de cima". Tendo-se em conta que parcela diminuta dos respondentes relacionou a melhoria da situação do proletariado a uma ação da classe (pressão sindical, greves, etc.) temos elementos capazes de nos proporcionar novas luzes para a compreensão do populismo. A consciência das próprias deficiências profissionais e educacionais, da carência dos requisitos sociais necessários para o êxito no mundo urbano e industrial, conjugada à inexistência de um movimento sindical poderoso e de outros meios de pressão "classista", conduz os migrantes a um pessimismo, a um sentimento de impotência, a uma heteronomia que os leva a depositar suas únicas esperanças nas mãos de entidades poderosas, como o governo, personificado em lideranças de tipo populista, aparentemente capazes de enfrentar os poderosos (os ricos, as grandes empresas, os grandes proprietários, etc.) em defesa dos indefesos e dos humildes.

As tendências observadas na tabela anterior repetem-se na que aparece a seguir, onde se indaga, especificamente, das possibilidades que os próprios entrevistados acreditam ter de melhorar de vida.

Nesta tabela, as perguntas foram "abertas", não tendo os entrevistados que optar entre alternativas propostas no questionário. Observe-se que, aqui, quando a questão diz respeito às possibilidades que se oferecem ao próprio indivíduo, nenhum mencionou uma eventual ação conjunta dos operários. A via individual aparece nitidamente como a mais factível. Os ferramenteiros são os mais "individualistas" dadas as referências, mais acentuadas entre eles, a "economizar" e a "estudar". Entretanto, se há uma categoria operária em condições ótimas de pressionar coletivamente as empresas, é a dos ferramenteiros. Mas a carência de mão de obra qualificada ofereceu-lhes boas condições de negociações individuais no mercado de trabalho, dificultando sua integração nas associações sindicais. Deste modo, se os ferramenteiros são os mais "otimistas", são igualmente os que mais acentuam a via individual, fato que, a nosso ver, não exclui a possibilidade de, se as circunstâncias exigirem, desenvolverem alguma forma de pressão "corporativista" sobre a empresa.

Tabela 36: "Que possibilidades o Sr. tem de melhorar sua situação?”

\begin{tabular}{|l|c|c|c|c|}
\hline & Operários- & Ferramenteiros & Mod. & Trad. \\
Economizar & $16 \%$ & $29 \%$ & $19 \%$ & $10 \%$ \\
Trabalhar mais & 19 & 12 & 38 & 5 \\
Obter promoção na Empresa Automobilística & 18 & 17 & 24 & 15 \\
Estudar, adquirir uma profissão & 13 & 29 & 19 & 5 \\
Não tem nenhuma possibilidade & 18 & 12 & 14 & 45 \\
Trabalhar por conta própria & 8 & - & 5 & 5 \\
Só com aumentos gerais de salário & 8 & - & - & 5 \\
Outras respostas & 13 & 12 & 5 & 20 \\
Não sabe & 5 & - & - & 5 \\
n- & 62 & 24 & 92 & 20 \\
\hline
\end{tabular}

Obs.: Respostas múltiplas. Soma das porcentagens superior a $100 \%$.

Devemos notar como parte ponderável dos entrevistados, sobretudo os Mod., equacionaram suas possibilidades futuras em termos de uma promoção no interior da própria Empresa Automobilística. Porém, outra vez, os mais pessimistas, em todos os sentidos, são os trabalhadores migrados recentemente para São Paulo. Entre eles é que se localiza a maior parcela dos que não veem nenhuma possibilidade de melhorar sua sorte (45\%). São também os que menos acreditam que podem ascender na hierarquia da empresa e os mais dependentes de aumentos gerais de salários. Ora, como esses aumentos não se encontram relacionados a uma pressão que parta da própria classe, o fato expressa bem a dependência que se encontram da política salarial do governo ou da empresa, e deste ângulo é revelador do sentimento de impotência e de incapacidade de alterar a ordem das coisas.

Por outro lado, novamente indicam os algarismos do quadro anterior que os grupos mais qualificados atribuem um valor considerável à educação e ao aprimoramento profissional como via de ascensão social (29\% dos ferramenteiros mencionaram este fator contra apenas 5\% dos Trab.) 
Aparentemente, os setores mais urbanizados e qualificados seriam mais conscientes da importância do fator educacional. Porém, poder-se-ia afirmar que os chegados há pouco a São Paulo desconhecem o fato de que a melhoria de seu padrão de vida ou a passagem a outro status social está condicionada à aquisição de novos conhecimentos? A nosso ver, falta-lhes, amiúde, base educacional mínima sobre a qual se possa alicerçar tentativa ulterior de aprimoramento profissional e de prosseguimento dos estudos, assim como meios financeiros e tempo para realizá-los. ${ }^{21}$ Deste modo, a orientação de seus esforços logicamente não pode dirigir-se nesse sentido e os meios para a efetivação do projeto de melhorar de vida apoiam-se unicamente no quantum de trabalho que o indivíduo está em condições de dar. "Trabalhar mais" equivale, pois, literalmente, a incrementar o esforço físico, a jornada de trabalho, mediante horas-extras na empresa ou em serviços externos.

Ao contrário do que às vezes se pensa, os resultados da pesquisa na Empresa Automobilística indicam que os migrantes nordestinos e os operários de baixa qualificação profissional, originários do "Brasil arcaico", mostram um grau de insatisfação e frustração bastante pronunciado no meio urbano. Se sua participação nas atividades sindicais ou nas do grupo socioprofissional em geral e medíocre, o fato não advém de um suposto ajustamento altamente satisfatório ao novo ambiente, de uma avaliação de tal modo positiva da nova condição operária que se transforme em obstáculo para a emergência de "comportamentos classistas" ou de uma "consciência revolucionária", negadora da sociedade de classes. Indubitavelmente, o novo contexto e sua nova situação, na cidade, são confrontados vantajosamente com o esquema anterior, mas isso não impede uma visão prospectiva

${ }^{21} \mathrm{O}$ menosprezo ou a subestimação da educação como via de ascensão social foi observado por Eunice R. Durhan na pesquisa sobre migrantes rurais. A autora levanta a hipótese de que tais atitudes decorreriam das influências do meio de origem: "Apesar das transformações que estão ocorrendo, a sociedade rural continua sendo uma sociedade pouco diferenciada, com enorme predominância de trabalhadores não especializados. Como predomina a técnica mais rudimentar, não há diversificação da atividade produtiva, não há tipo diferente de trabalho e, consequentemente, não existem tipos diferentes de trabalhadores. A não ser muito recentemente, e em regiões restritas, a única diferenciação possível é a que existe entre trabalho propriamente dito e supervisão do trabalho. Deste modo, o aumento da produção só pode ser visto como resultado de um aumento da quantidade de trabalho e não há transformação da qualidade de trabalho. Daí, inclusive, a depreciação da escola, que não constitui um instrumento de melhoria de vida, desde que não há, na sociedade rural, posições favoráveis a serem ocupadas pelo trabalhador escolarizado". Eunice R. DUHRAN, op. cit., pp. 120-121. pessimista, uma vez que a cidade e fonte de novas frustrações. Estes trabalhadores encontram-se numa situação ambígua. À aceitação abstrata e geral da ordem industrial, da cidade grande e das oportunidades que se lhes abrem corresponde a rejeição do status concreto que lhes é atribuído e da condição operária. A conjugação desses dois elementos impede a cristalização de uma consciência socialista e constitui forte empecilho para a efetiva integração do trabalhador no meio social operário. Falta-lhes a apreciação positiva da condição operária que estimule a integração no grupo. Se tal componente existisse, o descontentamento e o pessimismo poderiam resultar no fortalecimento da coesão interna do grupo e extravasar em termos de pressão coletiva. O que ocorre, no que tange às massas de origem rural, e que embora sejam as mais descontentes quanto ao trabalho e à remuneração, são também as que mais valorizam a empresa e, assim sendo, seu descontentamento não pode dirigir-se contra ela, e se perde num pessimismo impotente.

\section{A FORMAÇÃO DA CLASSE: ATITUDES ANTE A INDUSTRIALIZAÇÃO E O CAPITALISMO}

As conclusões alcançadas no estudo da Empresa Automobilística fornecem algumas pistas para uma apreciação mais ampla sobre as atitudes da camada operária ante a sociedade industrial em formação e sobre a empresa estrangeira no Brasil. Elas chamam a atenção para os obstáculos que se antepõem à emergência de uma consciência anticapitalista entre o proletariado que se forma num contexto econômico, social e político como o brasileiro. A instalação de uma grande empresa industrial se identifica com a industrialização, com o "progresso". Há uma aceitação da grande empresa capitalista com seus processos modernos de produção que não se poderia encontrar entre o proletariado que se constituiu nas fases iniciais da industrialização. Na Europa, a introdução do maquinismo significou inicialmente o despojamento dos instrumentos de produção do artesão; posteriormente, num processo que se inicia em fins do Século XVIII e chega a inícios do século atual, ocorre o desaparecimento dos ofícios tradicionais, e o operário, com a introdução do trabalho parcelado e em série, transforma-se em operário especializado na realização de tarefas cada vez mais simples. A expansão industrial significou uma contínua degradação do trabalho artesanal qualificado. Nas condições brasileiras, de transformação do trabalhador 
agrícola em operário industrial, o emprego fabril implica justamente o contrário, ou seja, a aquisição de uma profissão, ainda que esta seja a de simples operário semiqualificado. No caso das massas agrícolas brasileiras, que realizam sua incorporação ao sistema urbano-industrial do século XX, tem-se trabalhadores "despojados desde sempre" e para os quais a industrialização (e o capitalismo) não estão associados a descenso na escala de estratificação social, nem a rebaixamento das condições de vida.

As considerações anteriores não implicam na afirmação da inexistência de conflitos ou na negação de uma oposição de interesse entre os operários e a empresa. Mas - no que diz respeito aos trabalhadores - o fato significativo é que a percepção de interesses opostos e os conflitos surgidos, em termos de seus equacionamentos teóricos, não pode se inserir num arcabouço ideológico mais amplo que localize os fundamentos do antagonismo na propriedade privada dos meios de produção. Esta não é sentida como "moralmente reprovável", como fonte da "miséria operária". A luta contra a propriedade privada, ponto nuclear dos movimentos operários europeus do século passado, dos socialistas utópicos e de Proudhon a Marx, para o trabalhador brasileiro não pode cumprir as mesmas funções na motivação da ação sindical ou política. A crítica à propriedade privada e a esperança de recuperação dos instrumentos de trabalho perdidos expressaram, no movimento operário, o modo como se deu a formação da sociedade industrial na Europa. Ela é típica do período da pequena manufatura, da fase em que a natureza da tarefa realizada pelo trabalhador (já assalariado) não se distinguia notavelmente da que efetuava enquanto artesão. ${ }^{22}$

22 “... a única diferença entre o operário profissional desta época (a do trabalho qualificado polivalente) e o artesão individual é que a propriedade dos seus meios de produção e de seu trabalho lhe escaparam. Socialmente, a diferença é fundamental; psicologicamente, ela o é menos, pois o artesão sofria, ele próprio, há bastante tempo, a lei do mestre (aitre d'oeuvre) que repartia as encomendas. A reação do operário profissional polivalente, despossuído de seus instrumentos de produção, continua uma reação de proprietário: ele defende como seu bem mais caro a única propriedade que lhe resta: seu ofício". (...) "É certo que o sindicalismo de ofício esteve impregnado de ideologias diferentes: entre proudhonianos, bakunistas e "socialistas franceses" as rivalidades políticas eram muito fortes. Porém, olhando-as mais de perto, constata-se que os tipógrafos parisienses - de tendência proudhoniana - os companheiros da construção de Martin Nadaud, os relojoeiros do Jura, exprimiam suas reivindicações sociais sob um mesmo aspecto: $o$ socialismo, para uns e para outros, é reapropriação dos meios de produção de que foi despojado o artesão". Serge MALLET, La Nouvelle Classe Ouvrière, Paris, Senil, 1963 pp. 31 e 32.
As ideologias anticapitalistas que acompanharam a formação da classe operária europeia e que conectaram as ações reivindicativas imediatas a uma aspiração mais ampla de remodelação social estarão ausentes na formação do atual proletariado brasileiro. Encontrar-se-ão, é certo, fortes similitudes entre o sindicalismo existente no Brasil, no período anterior à Primeira Guerra, e o movimento operário europeu. Particularmente em São Paulo, onde a influência do imigrante se fez sentir de modo consideravelmente mais intenso do que em outras regiões do país, o movimento operário brasileiro retomou todos os temas do sindicalismo europeu, especialmente do da França. A influência da Carta de Amiens (1906) estará presente nas primeiras associações operárias do começo do século. ${ }^{23}$ Contudo, convém lembrar que a difusão das ideologias anarquistas e socialistas ficou restrita, em grande parte, a um proletariado estrangeiro, composto de imigrantes europeus - italianos e espanhóis, principalmente ${ }^{24}$ - extremamente minoritário no conjunto da população brasileira e marginalizado na vida política nacional.

${ }^{23}$ Cf., para a história do movimento operário brasileiro, Everardo DIAS, História das Lutas Sociais no Brasil, São Paulo, Editora Edaglit, 1962, Hermínio LINHARES, Contribuição à História das Lutas Operárias no Brasil, Rio de Janeiro, Baptista Souza e Cia., 1955; Antônio dos Santos FIGUEIREDO, A Evolução do Estado no Brasil, Empre. Indust. Gráfica do Porto, 1926; Abguar BASTOS, Prestes e a Revolução Social, Rio de Janeiro, Editorial Calvino, 1946. Astrogildo PEREIRA, Formação do PCB, Rio de Janeiro, Vitória, 1962. Para a interpretação propriamente sociológica, Cf. Aziz SIMÃO, O Sindicato e o Estado; José Albertino RODRIGUES, O Sindicato no Brasil. Seu Papel no Desenvolvimento Econômico; Evaristo de MORAES FILHO, O Sindicato Único no Brasil, Rio de Janeiro, Editora "A Noite", 1962; Fernando Henrique CARDOSO, "Le Proletariat Brésilien: Situation et Comportement Social", in: Ouvriers et Syndicats d'Amérique Latine, Sociologia da Travail, Paris, 1961; Octavio IANNI, "Transformações no Comportamento Político Operário in: Industrialização e Desenvolvimento Social no Brasil, Rio de Janeiro, Editora Civilização Brasileira, 1963; J V. Freitas MARCONDES: Radiografia de Liderança Sindical Paulista, São Paulo, Instituto Cultural do Trabalho, 1964; Leôncio Martins RODRIGUES, Conflito Industrial e Sindicalismo no Brasil, Difusão Europeia do Livro, São Paulo, 1966; "Classe Operária e Sindicalismo no Brasil", in: Leôncio Martins RODRIGUES, (ed.), Sindicalismo e Sociedade, São Paulo, Difusão Europeia do Livro, 1968; e "Sindicalismo y Desarrollo en el Brasil", Revista Latinoamericana de Sociologia, Buenos Aires, n. ${ }^{\circ} 1,1966$.

${ }^{24}$ Não se dispõe de estatísticas completas sobre o volume de trabalhadores estrangeiros então existentes no parque industrial paulista. Os dados fragmentários à disposição indicam que sua participação era assaz elevada. Em 1912, relatório publicado pelo Departamento Estadual do Trabalho sobre as condições de trabalho na indústria têxtil de São Paulo, abrangendo 31 fábricas da capital, uma de Santos e outra de São Bernardo, encontrou apenas 18\% de operários nascidos no Brasil, num total de 10.204 arrolados, Os italianos perfaziam 59\% do total, vindo a seguir os portugueses com $8 \%$. Mesmo nos serviços públicos, os estrangeiros superavam os 
A influência do anarcossindicalismo e do socialismo atingiu apenas o setor mais qualificado do proletariado do período anterior a 1930, se quisermos estabelecer uma data. A partir deste momento - quando o modelo de crescimento econômico baseado na exportação de produtos primários sofre sua maior crise no Brasil e a estrutura de poder tradicional se enfraquece, quando o processo de industrialização toma maior impulso - é que começa,verdadeiramente, a surgir uma classe operária nacional. Do ponto de vista da formação do proletariado, o outro fato importante é o decréscimo das correntes migratórias externas e o aumento do volume dos efetivos vindos das áreas rurais para os centros urbanos. O parque industrial passa, então, a recorrer mais intensamente ao trabalhador brasileiro. ${ }^{25} \mathrm{Em}$ consequência das mudanças que se operavam no plano político (ascensão de Vargas, controle estatal das associações operárias, legislação trabalhista, etc.) a tradição anarcossindicalista e socialista da fase anterior não se transmitiu à nova classe operária. Importante e ressaltar que as camadas que se inseriam no mercado de trabalho não se diferenciarão das anteriores apenas quanto à sua composição étnica ou quanto à fonte de seu recrutamento, mas também no que tange à sua composição profissional. Enquanto na fase anterior tratava-se de um proletariado composto, em grande parte, de "profissionais

nacionais no que tange ao número de trabalhadores braçais. De 2.299 operários recenseados, apenas 871 eram brasileiros natos. "Condições de Trabalho na Indústria Têxtil", Boletim do Departamento Estadual do Trabalho, ano I, n ${ }^{\text {os }} 1$ e 2, São Paulo, 1912.

${ }^{25}$ Os imigrantes estrangeiros, até 1920 , compreendiam mais de $95 \%$ do total de trabalhadores entrados no Estado de São Paulo. De 1901 a 1920, São Paulo recebeu 890.968 imigrantes estrangeiros e nacionais. O número de brasileiros de outros Estados não ultrapassou 68 mil. Porém, no quinquênio de 1936-40, entraram no Estado 293.852 trabalhadores nacionais, em contraposição a apenas 57 mil estrangeiros. A partir de então, incrementaram-se as correntes migratórias internas enquanto as de estrangeiros continuaram em descenso, modificando rapidamente a composição étnica do proletariado paulista. Cf. José Francisco CAMARGO, Crescimento da População de São Paulo e seus Aspectos Econômicos, São Paulo, Faculdade de Filosofia, Ciências e Letras (USP), 1952, e Exxodo Rural no Brasil, São Paulo, Faculdade de Ciências Econômicas e Administrativas (USP), 1957, e T.I.C. - Estatística de Imigração, publicação do Departamento de Imigração e Colonização, Secretaria da Agricultura do Estado de São Paulo, 1961. Consulte-se, também, para outras informações sobre as migrações internas: Vicente Unzer de ALMEIDA e Octávio Teixeira MENDES SOB., Migração Rural-Urbana, Secretaria da Agricultura do Estado de São Paulo, São Paulo, 1961; Celeste A. de Souza ANDRADE, "Migrantes Nacionais no Estado de São Paulo", Sociologia, São Paulo, maio de 1952; e Conjuntura Econômica, $\mathrm{n}^{\text {os }}$ de outubro de 1953; julho de 1954; dezembro de 1955 e maio-junho de 1956. A. JORDÃO NETO e Santa Helena BOSCO, Migrações, S. Paulo, Departamento de Imigração e Colonização, 1967. polivalentes" (para utilizarmo-nos de uma expressão consagrada pela sociologia industrial francesa), dotados de formação profissional mais aprimorada, a nova classe operária brasileira compor-se-á, cada vez mais, de trabalhadores desprovidos de verdadeira formação profissional, de "operários especializados" ${ }^{26} \mathrm{~A}$ incorporação desses efetivos passa a ser possível a partir do momento em que progridem a desqualificação do trabalho, a decomposição das tarefas, permitindo à indústria (particularmente seus setores de produção em massa e de bens de consumo) absorver trabalhadores submetidos apenas a rápido período de aprendizagem.

Algumas vezes se negligenciam esses aspectos de extrema relevância para a inteligência do comportamento do proletariado brasileiro e que decorrem, essencialmente, do fato de se tratar de um proletariado que se forma numa fase superior da tecnologia industrial. Entretanto, se no plano da produção essa determinação parece ser a mais relevante, cumpre destacar, mesmo rapidamente, os elementos político-sociais que atuaram concomitantemente. Pensamos, como observa Touraine, no "avanço da democracia ou da cultura de massa sobre o desenvolvimento econômico". ${ }^{27}$. Ao proletariado que se formou nesse contexto, abriram-se vias de acesso ao Poder, de participação política, de legitimação das associações profissionais e de garantia de certos direitos sociais e trabalhistas que não se ofereceram ao proletariado de países como a Inglaterra, França e Alemanha, nas primeiras fases do surto de industrialização. ${ }^{28}$ Por uma via paternalista,

26 "Propomos (...) que se distinga, o especialista, cuja redução (superficial) do campo de atividade se apoia sobre uma cultura profissional prévia. da qual é uma espécie de prolongamento, de coroamento, e o especializado. que exerce uma atividade parcelada, preparada por adestramento de gestos, no caso do O.S. (ouvrier spécialisé) e que não é precedida, com frequência nem sequer acompanhada, de uma formação geral, suscetível de marcar, explicar e ilustrar a "unidade de trabalho" situando-a em um conjunto". Georges FRIEDMANN, El Trabajo Desmenuzado, p. 150. Veja-se, também, do mesmo autor: "De quelques incidences psicologiques, sociales et morales dans l'evolution contemporaine des metiers industrieis", in: L’Année Sociologique, 3. a série, 1940-1948, tomo III, Paris, Presses Universitaires de France, 1949.

${ }^{27}$ Alain TOURAINE, "Industrialisation et conscience ouvriere à São Paulo", Ouvrièrs et Syndicats d'Amérique Latine, p. 87.

${ }^{28}$ Para a história do movimento operário na Europa, consulte-se: G. D. H. COLE: Short History of British Working Class, Londres, George Allen and Unwin,, Ltd., 1945; a obra clássica de Sidney e Beatrice WEBB, The History of Trade-Unionism, Londres, Longmans Green and Co., 1950 (1. ed. 1894) e, mais recentemente, Henry PELLING, A History of British TradeUnionism, Londres, Pelican Books, 1963; Robert BOTHEREAU, Historie du 
autoritária e controlada, o proletariado brasileiro, a partir de 1930, obteve indiretamente certa legitimação de suas associações. Se o controle estatal dos sindicatos foi repudiado pelos setores mais qualificados e organizados, de tradição anarcossindicalista, socialista, ou comunista mais recentemente, a massa de trabalhadores semiqualificados ou braçais aceitou a intervenção e a proteção que vinham de cima, e cujo apoio lhe parecia mais eficaz do que a oferecida pela organização autônoma da classe. ${ }^{29}$

Em meio à pobreza reinante entre as populações das áreas tradicionais, a industrialização, mesmo sob capital privado, identifica-se fortemente com melhores salários, novas oportunidades profissionais, novas vias de participação nas formas modernas da vida social. A valorização do industrialismo tem trazido consigo a aceitação do capitalismo e da grande empresa, o que dificulta o aparecimento de ideologias "proletárias" entre as camadas operárias recém-formadas.

Obviamente, para o caso brasileiro, não se trata de uma "preferência" pelo capitalismo, de uma opção deliberada, de uma adesão "voluntária" ao sistema e aos seus valores, nos moldes em que se pode encontrar, por exemplo, entre a liderança sindical norte-americana, implicando uma

Syndicalisme Français, Paris, Presses Universitaires de France, 1946; Jean MONTREUIL, Histoire du Mouvement Ouvrier en France, Paris, Aubier, 1946, Édouard DOLLEANS, Histoire du Mouvement Ouvrier, Paris, Librairie Armand Colin, 1953, III vols., Wolgang HIRSCH-WEBBER, Los Sindicatos en la Política, Madri, Editorial Tecnos, 1964. Veja-se também Harry W. LAIDLER, Social-Economics Movements, Nova York, Thomas Y. Crowel Co., 1945, 2.a edição. Para uma interpretação propriamente sociológica do sindicalismo e do movimento operário, consulte-se: Michel CROZIER, "Sociologia del Sindicalismo", e Alain TOURAINE e Bernard MOTTEZ, "Clase Obrera y Sociedad Global", in: Georges FRIEDMANN e Pierre NAVILLE, Tratado de Sociologia del Trabalho, II vol.

${ }^{29}$ Em 1945, Aziz SIMÃO, analisando os resultados eleitorais desse ano, observa a tendência dos setores operários mais qualificados e radicados há mais tempo em São Paulo de votarem no Partido Comunista enquanto os grupos menos qualificados davam seus votos ao PTB. Cf. "O Voto Operário em São Paulo", in: Anais do I Congresso Brasileiro de Sociologia, São Paulo, 1955. Sara CHUCID e Michel LOWY encontraram uma correlação entre radicalismo político e índices mais elevados de educação, urbanização e formação profissional. Cf. "Opiniões e Atitudes de Líderes Sindicais Metalúrgicos", Revista Brasileira de Estudos Políticos, Belo Horizonte, janeiro de 1962. Para uma apreciação da ideologia e da filosofia social que orientaram a intervenção estatal na "questão operária" durante o período de Vargas, consultemse os seguintes livros de Oliveira VIANNA: Problemas do Direito Corporativo, São Paulo, José Olympio, 1938; Problemas do Direito Sindical, Rio, Editora Max Limonad, 1943; e Direito do Trabalho e Democracia Social, São Paulo, José Olympio. 1951. tomada de posição doutrinária mais definida em favor da ordem competitiva e uma aceitação explicita de seus ideais. ${ }^{30}$

Entre os trabalhadores da Empresa Automobilística não se encontrou uma valorização do sistema capitalista e nem isso poderia ocorrer entre operários cuja participação no modo de vida e na cultura de massas é ainda incipiente. Por isso, evitamos sempre, deliberadamente, falar numa "adesão ao sistema", numa "introjeção" de seus valores. Pareceu-nos mais correto dizer de uma aceitação do industrialismo e da grande empresa, do "Brasil moderno", avaliados sempre instrumentalmente, enquanto se oferecem como um meio de satisfação de necessidades e preenchimento de expectativas de aproveitamento da ordem industrial. A aceitação do capitalismo efetua-se por vias indiretas, na medida em que a industrialização se realiza através do capital privado. Tais atitudes não implicam valorização do status quo, da ordem social global. De modo sumamente esquemático, e atribuindo aos trabalhadores uma clareza de formulação que possivelmente não possuem, pode-se dizer que há uma aceitação do industrialismo (e do capitalismo, na medida em que se confundem no Brasil) e uma rejeição de ordem social e política global. ${ }^{31}$

\footnotetext{
${ }^{30}$ Em 1943, o líder sindical William Green, presidente da American Federation of Labor, afirmava: "A AFL considera a propriedade privada, a empresa privada e a iniciativa privada como elementos permanentes na estrutura econômica de nosso Estado. Se alguma vez estiveram em perigo (...) estaremos entre os primeiros a combater pela sua manutenção”. Em 1945, Van A. Bittner, um dos dirigentes da central sindical então rival da AFL, o Congress for Industrial Organization (CIO), afirmava numa assembleia da National Association of Manufacturers: "Temos necessidade da empresa privada. Não há nenhum homem na indústria que acredite, mais do que nós, nessa forma de empresa tal como a conhecemos na América; não há nenhuma organização que acredite, mais do que o CIO em nossa fórmula americana de empresa privada". Citações extraídas do livro de Pierre WALINE, Les Syndicats aux États-Unis, Paris, Librairie Armand Colin, 1951, pp. 69 e 70. Como observa Lipset, houve por parte do proletariado dos EUA uma aceitação dos valores globais da sociedade norte-americana. Cf. Seymour Martin LIPSET, "Le Prolétariat americain et les valeurs de la societé américaine", in: Sociologie du Travail, abril-junho e julho-setembro de 1961. Cf. também Selig PERLMAN, A Theory of Labor Movement, Nova York, August M. Kelly, 1949; Joseph RAYBACK, A History of American Labor, Nova York, The MacMillan Co., Florence PATERSON, American Labor Unions, Nova York, Harper and Brother Publisher, 1952; Mark PERLMAN, Labor Unions Theories in America, Illinois, Row, Peterson and Co., 1958.

${ }^{31}$ Este ponto será desenvolvido mais adiante, no capítulo IV, quando tratarmos das atitudes dos trabalhadores ante a política.
} 
A contradição entre uma atitude "positiva" com relação à moderna empresa industrial (privada ou estatal, quer se trate de um estabelecimento como a Empresa Automobilística ou como a Petrobrás) e uma atitude "negativa" ante a ordem social, política e econômica inclusiva permite equacionar mais precisamente o comportamento político das camadas operárias brasileiras. A crítica ao sistema não encontra um fundamento nas condições de trabalho concretas. Nestas condições, as "ideologias proletárias" não acham terreno propício para florescimento, uma vez que não passam pela fábrica, isto é, não partem de uma repulsa à organização privada do trabalho industrial. Em parte, o êxito dos movimentos socialistas na Europa deveu-se ao fato de que a crítica geral ao sistema encontrava sólido fundamento nos movimentos em prol de melhores salários e condições de trabalho. Houve uma estreita associação entre os planos profissional, econômico, político e ideológico. A perspectiva socialista dava sentido revolucionário aos movimentos profissionais enquanto esses, por sua vez, pareciam validar, teórica e praticamente, os fundamentos gerais dos programas de reconstrução social. Nas condições brasileiras, a perspectiva socialista não pode encontrar apoio em movimentos classistas fundados numa repulsa ao capitalismo (como sistema) que parta de uma rejeição da organização do trabalho fabril.

Essas considerações não implicam em negar, em termos normativos, a validez de uma eventual "solução socialista" nem tampouco significam afirmar, do ângulo de uma pura análise objetiva da realidade nacional, sua impossibilidade histórica como alternativa possível requerida para se levar a cabo a industrialização e a superação do subdesenvolvimento. Pode-se pensar que a "alternativa socialista" imponha-se a partir de necessidades globais da sociedade nacional, de planejamento, de desenvolvimento das forças produtivas e de afirmação da soberania nacional, ou seja, mais sob a pressão de amplos setores populares que visam ampliar sua participação no consumo do que sob a ação de uma classe (o proletariado industrial) que, partindo da negação da organização do trabalho capitalista, orientese para a reorganização da sociedade "à sua imagem".

\section{OS TRABALHADORES E O CAPITAL ESTRANGEIRO}

Os resultados da pesquisa na Empresa Automobilística oferecem ainda outras sugestões relativas às atitudes dos trabalhadores ante o capital estrangeiro. Nesse particular, a companhia em questão constitui área privilegiada para a observação, pois representa, tipicamente, a moderna empresa estrangeira no Brasil, embora a participação de capitais nacionais seja relativamente elevada. Desse modo, os resultados da investigação podem fornecer importantes elementos para a avaliação das atitudes operárias ante as empresas estrangeiras em geral. ${ }^{32}$

Desde logo, não se observou entre os trabalhadores a existência de críticas à empresa estribadas no fato de se tratar de um estabelecimento estrangeiro. Pode-se dizer que a origem externa do capital não se apresenta, ao trabalhador, como o critério básico dos julgamentos, positivos ou negativos, que faz da empresa.

Foi possível notar entre alguns entrevistados certo ressentimento, muito tênue, contra os "estrangeiros" (imigrantes) que, em nossa opinião, não chega a dar origem a um sentimento generalizado de hostilidade. Alguns trabalhadores afirmavam que os cargos e funções mais importantes estavam monopolizados por não brasileiros. As críticas, contudo, não se dirigiam especificamente aos norte-americanos, mas aos estrangeiros em geral. E que, proporcionalmente ao seu número, o pessoal de outras nacionalidades ocupa grande parte das posições de mando e supervisão. No momento da pesquisa, o pessoal americano era extremamente reduzido, limitando-se aos altos escalões da hierarquia da empresa e com muito pouco contacto direto com os operários. As críticas que por vezes se faziam ouvir referiam-se aos estrangeiros de outras nacionalidades, mais próximos dos trabalhadores. Não pudemos perceber, na empresa, a existência de discriminação contra o trabalhador nacional. A elevada proporção de estrangeiros explica-se, de um lado, é óbvio, pela presença das correntes migratórias em São Paulo e, de outro, pela sua qualificação profissional, via de regra superior à dos nacionais. ${ }^{33}$ Mas o ponto que nos interessa aqui é

${ }^{32} \mathrm{O}$ volume de trabalhadores estrangeiros e bastante elevado. Entre os "horistas", num total de 706 estrangeiros, predominam os espanhóis (217), seguidos dos italianos (196), dos portugueses (87), dos japoneses (27) e inúmeras outras nacionalidades. Entre os "mensalistas", vêm em primeiro lugar os italianos (92), e em seguida os espanhóis (56), os portugueses (26), os gregos (15), os franceses e austríacos (14), etc., num total de 382.

${ }^{33}$ Não se trata apenas de uma qualificação profissional mais completa ou de conhecimentos técnicos e especializados, mas de uma atitude geral sobre o trabalho, de atributos sociais e culturais que levam à formação de tipos de personalidade mais aptos a preencher status $e$ papéis na organização social da empresa. Conhecem-se já os obstáculos que a ordem social tradicional e escravista antepôs à cristalização de atitudes e valores positivos com relação ao trabalho e que colocaram particularmente as camadas negras em condições desvantajosas na 
outro e poderia ser sintetizado nas seguintes indagações: Constitui a empresa estrangeira, operando no setor industrial, fator de fermentação de atitudes e valores de tipo nacionalista entre os operários? Como os empregados encaram o capital estrangeiro?

Para o encaminhamento de nossas reflexões convém distinguir dois tipos diferentes de empreendimentos estrangeiros nas áreas subdesenvolvidas: I) a empresa estrangeira operando no setor manufatureiro, produzindo para o mercado interno competitivo, inserida num grande centro urbano e exercendo, no plano econômico imediato, um efeito dinamizador sobre o conjunto da economia; II) A empresa estrangeira que, destinando sua produção para o mercado externo em situação de monopólio, apodera-se das fontes nacionais de matérias-primas, no setor da mineração ou da agricultura, utilizando, às vezes, escasso equipamento e recorrendo abundantemente a uma mão de obra local de baixa qualificação e mal remunerada. Este caso se caracteriza nitidamente quando o empreendimento se localiza fora de centros urbanos importantes, dando origem a comunidades que se organizam em função da atividade da empresa. Amiúde, os postos de chefia são monopolizados por pessoal alienígena, contratado alhures, sem efetiva ligação com a comunidade local. Ilustram bem esta situação os empreendimentos estrangeiros no setor da mineração.

É sabido que os estabelecimentos de exploração mineira originam, por excelência, situações de trabalho propiciadoras para a emergência de relações industriais tensas e de conflitos violentos. Kerr e Siegel, ${ }^{34}$ estudando a ocorrência de greves em vários países durante longo período,

competição no mercado de trabalho. Não pretendemos nos estender nesse assunto. A citação abaixo, de F. Fernandes, referida à situação do negro e do mulato nos primórdios da industrialização paulista, conserva muito da sua validez: "A recusa de certas tarefas e serviços; a inconstância na frequência ao trabalho; o fascínio por ocupações reais ou aparentemente nobilitantes; a tendência a alternar períodos de trabalho regular com fases mais ou menos longas de ócio; a indisciplina agressiva contra o controle direto e a supervisão organizada; a ausência de incentivos para competir individualmente com os colegas e para fazer do trabalho assalariado uma fonte de independência econômica - essas e outras "deficiências" do negro e do mulato se entrosavam à complexa situação humana com que se defrontavam no trabalho livre". Florestan FERNANDES, A Integração do Negro à Sociedade de Classes, São Paulo, Editora Nacional, 1966, pp. 13-14, I vol.

${ }^{34}$ Clark KERR e Abrahan SIEGEL, "The Interindustry Propensity to Strike - An International Comparison", in: Robert DUBIN, Arthur KORNHAUSER e Arthur ROSS, (eds.), Industrial Conflict, Nova York, MacGraw-Hill Book, 1954. apresentam o setor da mineração como o de mais elevada propensão para a ocorrência de greves operárias (juntamente com o de portos e docas). Concorrem para isso diversos fatores, tanto os que são inerentes ao tipo da atividade econômica - trabalho mais árduo e perigoso - como outros que derivam do isolamento da comunidade operária ante outros setores sociais. “... o isolamento, nota E. Falleto, favorece o que se poderia chamar de 'obreirismo' e possibilita igualmente certa coesão cultural entre as massas operárias. Pode-se também notar que, muitas vezes, ocorre um paralelismo entre o sistema social existente na comunidade e o que é próprio do sistema industrial que lhe dá origem (...). A definição da comunidade a partir do tipo de atividade efetuada - o centro mineiro ou o complexo industrial isolado - determina que a ação política apareça mareada pelos problemas gerados na indústria. Neste caso, o conflito político aparece como similar ao conflito industrial. Além disso, o isolamento conduz os grupos operários a preocuparem-se, fundamentalmente, com os problemas do trabalho, criando uma mentalidade operária e proporcionando valiosos elementos para a formação de uma consciência de classe". ${ }^{35}$

A violência e o acirramento dos antagonismos não dependem de ser a empresa nacional ou estrangeira. Mas, neste último caso, tem-se o ambiente ideal para a cristalização não somente de uma consciência de classe como também de uma consciência nacionalista entre os operários, na medida em que a posição de dominação na empresa identifica-se com a de um grupo alienígena, e diferenciações de ordem étnica e cultural contribuem para aprofundar a separação entre os trabalhadores e a direção da empresa. Os movimentos nacionalistas tendem a encontrar sólido apoio numa situação concreta de trabalho e os conflitos trabalhistas, por sua vez, constituem fonte permanente de estímulo às lutas contra o capital externo.

Ora, tal não é precisamente o contexto geral que envolve uma companhia estrangeira como a Empresa Automobilística. Dadas suas características salientadas páginas atrás, e especificamente a apreciação altamente favorável que dela fazem os empregados, pode-se ver que, mais do que criar "situações propiciadoras" para a emergência de um sentimento nacionalista entre seus empregados, ela contribui para obstruí-lo.

${ }^{35}$ Enzo FALETTO, "Industrialização e Classe Operária na América Latina”, in: Leôncio Martins RODRIGUES (ed.), Sindicalismo e Sociedade, São Paulo, Difusão Europeia do Livro, 1968, pp. 321 e 322. 
Caio Prado Jr., discutindo o conceito de "burguesia nacional", insiste nos laços de interesses que uniram, desde a formação da sociedade brasileira, o capital nacional com o internacional. As divergências entre os grupos econômicos brasileiros e os estrangeiros - segundo o autor expressariam casos particulares e oposições momentâneas que não seriam suficientes para acarretar uma política de oposição sistemática dos industriais brasileiros aos investimentos internacionais.

Essa posição da burguesia brasileira, em face da questão do imperialismo, de fato o ignorando, evidencia que, realmente, não o sente e percebe, limitando-se a considerar o fato concreto e imediato da afluência e presença no país de empreendimentos estrangeiros. E sob este aspecto, a penetração do imperialismo na economia brasileira e suas atividades não podem ser para a burguesia brasileira, ou qualquer dos seus setores tomados em conjunto, motivo de queixas. Em nenhum outro período da história brasileira, como nestes últimos vinte anos em que o capital imperialista literalmente submergiu a nossa economia, a burguesia progrediu mais em seus negócios e mais enriqueceu. E progrediu e enriqueceu precisamente, em boa parte, graças ao esforço, impulso e exemplo que the trouxeram os empreendimentos e iniciativas imperialistas. Não somente isso é um fato incontestável, mas ainda a burguesia está plenamente consciente dele. ${ }^{36}$

Caio Prado não estende sua análise ao comportamento de outras camadas sociais ante o capital estrangeiro, mas, o que parece indiscutível é que, mutatis mutandis, tampouco o proletariado industrial, para repetirmos suas palavras, "teve motivo de queixas". No caso específico da indústria automobilística, parece claro que nenhum setor social importante (operários, camadas médias e superiores) sentiu seus interesses econômicos ou sua situação social prejudicados pelos investimentos externos. Não se trata, predominantemente, de uma situação em que a entrada do capital estrangeiro, com equipamento mais moderno e mais competitivo, acarrete a eliminação de indústrias nacionais estabelecidas, aumentando o desemprego, arruinando camadas artesanais ou destruindo ofícios preexistentes. O impulso econômico da fase desenvolvimentista foi logrado em grande parte graças à entrada de investimentos externos. Novos empregos se ofereceram em indústrias mais poderosas e melhor organizadas; os elevados lucros obtidos pelas empresas

${ }^{36}$ Caio PRADO JR., A Revolução Brasileira, São Paulo, Editora Brasiliense, 1966, pp.188-9. estrangeiras permitem-lhes o pagamento de salários mais elevados e a observância mais estrita da legislação trabalhista. Seria falso supor que a entrada do capital estrangeiro repercutiu diretamente e de modo negativo sobre as condições de vida das camadas operárias. Na realidade, quaisquer que sejam as consequências, a longo prazo, da contínua penetração do capital estrangeiro na economia nacional, seus efeitos não são sentidos negativamente pelos grupos sociais empregados em tais empresas. Assim, esses grupos tendem a avaliar o empreendimento estrangeiro segundo os benefícios imediatos que dele retiram. $\mathrm{O}$ capital nacional confina-se progressivamente nos setores industriais tradicionais, nos pequenos estabelecimentos, deixando para o capital externo (ou para o Estado) os ramos de bens de produção e os setores mais dinâmicos e modernos (petroquímica, farmácia, eletrônica, etc.). ${ }^{37} \mathrm{O}$ capital nacional mantém-se nos setores onde prevalecem, comparativamente, as técnicas gerenciais, as formas de organização do trabalho e da produção mais atrasadas. Em tais condições, é fácil compreender a preferência, por parte dos operários, pelas grandes companhias estrangeiras.

Não se deve inferir das observações anteriores que se afirme a impossibilidade de se abranger a população operária (mesmo daquela parcela empregada em estabelecimentos estrangeiros) em movimentos de tipo nacionalista. A propagação do nacionalismo - e a integração das camadas operárias em movimentos políticos desta natureza - pode ser estimulada por outros fatores não determinados pela situação de emprego, como por exemplo, a ideia de que a problemática do desenvolvimento nacional e de justiça social só poderá ser satisfatoriamente equacionada em termos de uma política geral de controle, restrição ou combate ao capital estrangeiro, em termos de uma repulsa a influencia dos grupos financeiros internacionais na vida nacional, à subordinação da política externa à de outros países, etc. Nos países subdesenvolvidos, o nacionalismo se tem oferecido, constantemente, em conjugação com medidas de natureza socialista ou estatizante como uma alternativa negadora do status quo.

${ }^{37}$ Cf. Fernando Henrique CARDOSO, "Hégémonie bourgeoise et indépendence économique", Les Temps Modernes, Paris, outubro de 1967, $\mathrm{n}^{\circ}$ 257. Examinando os dados e informações relativos à formação de capital e à evolução da participação do capital estrangeiro, do capital nacional e do Estado nos diferentes ramos de atividade econômica, F.H. Cardoso conclui que “... com a formação de setores industriais de infraestrutura e de setores industrialmente importantes como os de mecânica pesada - sob controle estatal ou estrangeiro - o termo genérico "burguesia nacional" perdeu seu sentido explicativo" (p. 678) 
Constitui, como mostram vários exemplos, poderoso instrumento de mobilização e integração da população no esforço de desenvolvimento econômico e social. Porem, para a análise sociológica e política e importante distinguir as diferentes "situações propiciadoras", ou seja, as situações que se apresentem, privilegiadamente, como capazes de estimular fortemente o surgimento de movimentos de cunho nacionalista. O meio socioprofissional, num contexto como o que se mencionou há pouco (centro mineiro ou empresa estrangeira isolada) constitui uma dessas situações altamente propiciadoras. Porem, empresas estrangeiras modernas operando num grande centro urbano e produzindo para o mercado interno parecem não ter o mesmo efeito, por maior que seja a participação do capital estrangeiro no conjunto da economia nacional. Por um lado, e certo que o peso dos investimentos externos pode aguçar, como contrapartida, correntes nacionalistas. Mas, por outro lado, e no que tange aos trabalhadores, para que o contexto socioprofissional constitua uma "situação propiciadora" é necessário, primeiramente, que as relações de trabalho na empresa estrangeira sejam definidas pelos empregados em termos de relações antagônicas e, depois, que o "inimigo" seja nitidamente caracterizado como "estrangeiro", de modo a que se estabeleça a conexão entre a dominação social, no plano da empresa, e a dominação estrangeira, no plano nacional.

Como vimos, os operários não só não foram prejudicados quando da instalação da Empresa Automobilística como não definem as relações com a companhia como sendo de natureza essencialmente conflitiva. Pelo contrário. Percebem-nas como uma troca recíproca de serviços; não se sentindo "explorados", não podem ver no estrangeiro um "explorador", tanto mais que avaliam positivamente as empresas estrangeiras em comparação com as nacionais. Assim, a julgar pelo que se verifica entre os operários estudados, a situação de trabalho numa empresa estrangeira, atuando no setor manufatureiro, não contribui especialmente para o aparecimento de atitudes hostis ao capital externo no seio das camadas operárias brasileiras. Não se encontrou nenhuma crítica à Empresa Automobilística que tivesse como ponto de referência o fato de se tratar de um empreendimento estrangeiro. E, de um modo geral, a porcentagem de trabalhadores que preconizava soluções para o desenvolvimento econômico a partir de uma ótica nacionalista era extremamente minoritária. Quando se indagou: "O que é preciso fazer para que o Brasil progrida", apenas 8\% dos respondentes ofereceram respostas nas quais se pode perceber a adoção de teses nacionalistas. ${ }^{38 \cdot}$ Entretanto, o fato significativo é que essa minoria não era especialmente hostil à Empresa Automobilística. Suas opiniões derivavam de considerações de outra ordem, de cunho ideológico e político geral.

Deste prisma, pode-se aventar a hipótese de que a emergência de uma consciência nacionalista agressiva entre o proletariado industrial dificilmente poderia surgir de uma situação concreta de trabalho em empreendimentos estrangeiros do tipo que estamos analisando, mas sim de fatores políticos e ideológicos mais amplos. Necessitaria passar por uma elaboração teórica e doutrinária que não parta do contexto profissional imediatamente vivido. Parece, portanto, que o nacionalismo, como fenômeno de massas e como corrente ideológica capaz de atrair e pôr em movimento diferentes segmentos sociais precisaria encontrar outros estímulos que não derivem de uma opção meramente ideológica e que não se fundamentem exclusivamente em pressupostos de ordem profissional. Dito de outro modo: pode-se supor que a adoção de medidas nacionalistas decorram e se imponham tecnicamente como as mais adequadas, da perspectiva, por exemplo, de um objetivo desenvolvimentista. Mas, deste ângulo, é patente que o nacionalismo só poderia sensibilizar os grupos intelectualizados e os que detêm os centros de decisão; os setores populares, em tal caso, só poderiam ser movimentados "de fora" e deliberadamente. Contudo, os grandes movimentos políticos e sociais não se originam (e não dependem para seu êxito) da validez científica de seus pressupostos teóricos, mas de sua capacidade de preencher determinadas expectativas sociais mais amplas, de responder politicamente a aspirações comuns de largos setores da população, envolvendo fortes componentes emocionais. As proposições nacionalistas encontram campo propicio quando se apresentam como uma opção que se situa no plano da nação, na proporção em que aparecem como a alternativa adequada (e desejada) para lograr a efetivação de potencialidades (reais ou supostas) do país, como, por exemplo, a realização de um projeto desenvolvimentista ou de afirmação nacional. As situações propiciadoras para a exacerbação dos sentimentos nacionalistas emergem basicamente neste nível, quando os "interesses

38 Classificamos como "nacionalistas", respostas deste tipo: "É preciso financiamento aos agricultores e à indústria nacional. $\mathrm{O}$ nosso mal é que os lucros deveriam ser movimentados aqui. O que interessa é que o Brasil cresça e não o estrangeiro". "Nosso pais é rico. Então deviam criar mais indústria e dar mais valor nossa indústria e não à de fora"."É preciso fazer com que o Brasil não precise de nenhum país estrangeiro. Nacionalizar o país e pensar mais no povo". 
nacionais" parecem prejudicados por uma potência estrangeira, quando as aspirações de afirmação da nação parecem obstadas pela influencia externa, quando a política nacional parece ditada e comandada por outra potência. $\mathrm{O}$ desenvolvimento e consolidação de movimentos populares nacionalistas e sua influência sobre as grandes decisões - num país não submetido à dominação estrangeira direta e formado nas tradições culturais do Ocidente são travados pela inexistência de "situações propiciadoras" capazes de afetar de modo imediato, constante e direto os diversos segmentos da população na sua vivência diária. Assim, os movimentos políticos estritamente nacionalistas não têm conseguido sensibilizar mais profundamente os setores operários, não só porque a participação política dos trabalhadores brasileiros é, por si mesma, muito limitada como também, porque não têm conseguido estabelecer uma vinculação mais direta entre as suas teses e a situação de trabalho e de vida de amplos setores populares. ${ }^{39}$

\footnotetext{
${ }^{39}$ Constitui exceção à afirmação acima a situação de trabalho em empresas estatais, como a

Petrobrás, por exemplo, que por si parece ser estimuladora de uma consciência nacionalista entre seus empregados.
}

\section{OS TRABALHADORES E O SINDICATO}

\begin{abstract}
A
ntes de passarmos à análise das atitudes do grupo estudado ante o sindicato, convém retomar algumas considerações feitas anteriormente. Para os fins que interessam a este capítulo, o primeiro ponto a ser destacado e a visão instrumentalista que os operários têm da Empresa Automobilística. Ela e avaliada em termos das oportunidades que oferece para a concretização dos projetos de melhoria de vida e o de ascensão social. O segundo ponto relaciona-se à remuneração do trabalho. Vimos que não só a grande maioria dos entrevistados considera o salário recebido como "justo" como também o concebe como uma troca recíproca de obrigações. Os operários consideram que e de interesse da própria companhia pagar-lhes um salário adequado em decorrência dos altos lucros que, forçosamente, uma grande empresa deve auferir. Este ponto constitui um dos elementos centrais para que se entenda a medíocre importância que assume o sindicato na vida desses trabalhadores. $E$ patente que o salário - bem como outras vantagens que os operários valorizam - não aparece para o grupo como o resultado de uma pressão coletiva ou de uma ação sindical. Assim sendo, consideram-no como inerente às indústrias do ramo. Ao nível da mera constatação dos fatos, assim é efetivamente. A indústria automobilística, como se sabe, instalou-se rapidamente, mercê dos estímulos e favores governamentais. Foi constrangida a encontrar e preparar operários especializados num mercado de trabalho relativamente carente de trabalhadores qualificados, tanto mais que a expansão do setor se acompanhava do crescimento da indústria de autopeças, aumentando a procura de mão de obra. As fábricas de veículos foram obrigadas a elevar os salários e oferecer outras vantagens a fim de atrair e selecionar operários num tipo de produção que requer certo grau de precisão, cuidados técnicos e, sobretudo, responsabilidade na execução das tarefas. Deste modo, desde o início, os salários pagos no ramo tenderam a manter-se em nível superior aos do conjunto da indústria paulista. Demais, em parte por razões de ordem técnica e, em parte, em função da política de relações humanas, a Empresa Automobilística orientou-se no sentido da promoção interna, do aproveitamento de seus próprios empregados para as novas vagas que se abriam na hierarquia da companhia. Os trabalhadores mais capazes e
\end{abstract}


mais antigos tiveram, destarte, efetivas possibilidades de ascensão que não ocorreram em outras indústrias e não soem acontecer neste mesmo ramo em outros países. ${ }^{1}$ Estas chances, e provável, desaparecerão quando a indústria automobilística brasileira atingir sua maturidade. Porém, quando das entrevistas, a imensa maioria dos trabalhadores com algum tempo de casa já tinha obtido pelo menos uma promoção. A Empresa Automobilística põe em prática um sistema de promoção bastante escalonado e diversificado, de modo a possibilitar aos operários pequenas ascensões em períodos de tempo relativamente curtos, dando aos empregados a impressão de que estão em contínuo processo de elevação na hierarquia da empresa e que seus esforços são recompensados. Os dados abaixo mostram, sem necessidade de maiores comentários, como a partir de mais de um ano de casa a grande maioria dos entrevistados tinha tido pelo menos uma promoção.

Tabela 37: "Durante o período em que o Sr. trabalhou na Empresa Automobilística, o Sr. teve alguma promoção?"

\begin{tabular}{|l|c|c|c|c|}
\hline Tempo de permanência na empresa & Sim \% & Não \% & & Totais \\
Menos de um ano & 27 & 73 & $(100 \%)$ & 15 \\
Um ano & 77 & 23 & $(100 \%)$ & 92 \\
Dois anos & 88 & 12 & $(100 \%)$ & 8 \\
Três anos & 93 & 7 & $(100 \%)$ & 15 \\
Quatro anos & 75 & 25 & $(100 \%)$ & 12 \\
Cinco anos & 85 & 15 & $(100 \%)$ & 13 \\
Seis anos & - & - & - & - \\
Sete anos & $100 \%$ & 0 & $(100 \%)$ & 1 \\
\hline
\end{tabular}

O terceiro ponto a ser destacado - e para o qual não chamamos atenção nas páginas antecedentes - é a política de reajustamentos salariais da Empresa Automobilística. Esta adotou como praxe a elevação dos salários a curto prazo, em consonância com a desvalorização da moeda, adiantando-se aos acordos anuais efetuados entre sindicatos operários e patronais. Essa prática, eliminou uma área de atrito com os empregados, única, aliás, no Brasil, que se tem mostrado capaz de acarretar mobilizações coletivas relativamente importantes de trabalhadores, e deflagração de

1 "Em tempos normais, apenas de oito a dez vagas, no nível da supervisão, se abrem cada ano nesta fábrica de quase seis mil operários", nota Ely CHINOY no estudo sobre operários da indústria automobilística nos EUA, "The Tradition of Opportunity and the Aspiration of the Automobile Worker", op. cit., p. 505, Cf. também Charles R. WALKER e Robert H. GUEST, The Man on the Assembly Line. greves. Assim se explica porque - com exceção do movimento de curta duração dos ferramenteiros - não tenha ocorrido, até o presente, nenhuma greve na Empresa Automobilística. ${ }^{2}$

Em tal contexto (parece quase ocioso dizer) as condições propiciadoras para a emergência de padrões coletivos de ação são em grande parte eliminadas. Para o trabalhador, a organização sindical parece desnecessária, pelo menos enquanto instrumento de pressão sobre a empresa. Com efeito, a proporção de trabalhadores sindicalizados é baixa. Entre os ferramenteiros a porcentagem é de $39 \%$. Entre os operários, apenas $21 \%$ são sindicalizados.

Se a proporção de sindicalizados em si mesma parece-nos baixa, em comparação com a de trabalhadores sindicalizados no conjunto da categoria, ela parece elevada. Faltam dados precisos sobre a proporção de operários sindicalizados no Brasil. Contudo, estabelecendo-se a relação entre o número de operários em condições de votar nas eleições sindicais e o número de trabalhadores existente no respectivo ramo industrial, é possível chegar a uma estimativa grosseira da porcentagem de sindicalizados em alguns ramos. Assim, em São Paulo, para os setores metalúrgico e têxtil, encontrou-se $13 \%$ em 1961; para os gráficos, 34\% e para os trabalhadores das indústrias químicas e farmacêuticas, $8 \%$ em 1962. ${ }^{3}$ Consultando-se os fichários dos diversos sindicatos, é possível encontrar um maior volume de operários sindicalizados. Convém, contudo, não nos enganarmos. Na maior parte das vezes, os sindicatos não mantém organizados os cadastros de filiados, conservando em seus registros trabalhadores que há muito não contribuem para a entidade. O Prof. José Albertino Rodrigues, que por muitos anos dirigiu o Departamento Intersindical de Estatística e Estudos SócioEconômicos, observa: “... todos os dados apresentados sobre sindicalizados

${ }^{2}$ Costuma a Empresa Automobilística, quando da ocorrência de greves no setor, conceder férias coletivas a seus operários. Em outro trabalho (Conflito Industrial e Sindicalismo no Brasil, II Parte, "Greves Operárias em São Paulo") procuramos mostrar como os movimentos grevistas em São Paulo constituem resultado de uma ação que parte de fora da empresa industrial. Em outras palavras: o que acarreta efetivamente a paralisação do trabalho numa determinada fábrica é a presença do piquete de greve, organizado pelos ativistas sindicais. Raramente, pela ausência de organizações sindicais de local de trabalho, e possível lograr-se, no caso de uma greve decretada pelo sindicato, a paralisação da empresa contando Unicamente com o apoio dos próprios operários do estabelecimento. Concedendo férias a seus empregados, a Empresa Automobilística evita a presença dos piquetes grevistas em suas portas e o envolvimento de seus operários no movimento desencadeado pelo sindicato. Cf. Leôncio Martins RODRIGUES, ibid. 
devem receber uma correção. Referem-se sempre ao número de associados inscritos nos sindicatos, mas nem todos os trabalhadores inscritos mantêm em dia com suas obrigações associativas e, a rigor, apenas nominalmente podem ser considerados sócios. Um grande número de trabalhadores procura sua organização sindical no momento em que tem um grave problema a enfrentar, seja de natureza jurídica, seja de natureza assistencial. Não sendo sócio precisa adquirir essa qualidade para ser atendido - e o faz incontinenti. Resolvido o problema, nem sempre continua a frequentar o sindicato, embora nele permaneça inscrito". ${ }^{4}$

Os trabalhadores da Empresa Automobilística não fazem exceção às observações de José A. Rodrigues. A grande maioria dos operários sindicalizados, sendo o pagamento das cotizações efetuado pela empresa através do desconto na folha de pagamento, raramente comparece ao sindicato. Alguns respondentes chegaram a declarar que nem mesmo sabem a localização da sede. Do total de entrevistados, apenas 6\% declararam que comparecem ao sindicato assiduamente.

Tabela 38: “O Sr. frequenta o sindicato?” (Trabalhadores Sindicalizados)

\begin{tabular}{|l|c|c|}
\hline & Operários & Ferramenteiros \\
Nunca & $91 \%$ & $45 \%$ \\
Às vezes & - & 33 \\
Com frequência & 9 & 22 \\
& $(100 \%)$ & $(100 \%)$ \\
\hline
\end{tabular}

Nota-se não só que a porcentagem de sindicalizados é mais elevada entre os ferramenteiros, como são esses, em comparação com os demais trabalhadores, os que costumam comparecer com mais frequência à sede da organização sindical. Foi neste grupo que pudemos encontrar respostas como essas:

"Vou algumas vezes, quando tem alguma reunião importante. O certo seria ir a todas elas".

"Vou uma ou duas vezes por mês, por causa da consulta médica e do dentista. Vou também quando há alguma assembleia importante".

"Vou a quase todas as assembleias e sempre que preciso de algum esclarecimento".

\footnotetext{
4 José Albertino RODRIGUES, O Sindicato no Brasil. Seu Papel no Desenvolvimento Econômico.
}

Os resultados, nesse aspecto, confirmam outras indicações sobre a participação operária nas associações profissionais: ela é mais elevada entre setores mais qualificados. Já S. Chucid e M. Lowy haviam chegado à mesma conclusão, numa enquete entre dirigentes sindicais metalúrgicos. $\mathrm{Na}$ verdade, a afirmação parece ser válida não apenas para o Brasil, mas igualmente para outros países ${ }^{5}$ Lowy e Chucid encontraram uma correlação entre três variáveis: urbanização, grau de escolaridade e nível de formação profissional. No caso dos ferramenteiros há, como se mostrou, coincidência entre esses atributos, possuindo esta categoria profissional não só um nível de educação formal e de formação profissional superior (ambas, aliás, relacionadas) como igualmente maior experiência de vida urbana. Nestas condições, não seria o caso de indagar a que fator se deve a taxa mais elevada de sindicalização nesse grupo? Não se dispõe de elementos para responder diretamente à questão, uma vez que os referidos atributos não aparecem isolados. Porém, outros dados nos levam a supor que, se o problema é pertinente, a taxa de sindicalização parece mais relacionada à formação profissional do que à urbanização ou ao grau de escolaridade. Com efeito, a proporção de sindicalizados entre os trabalhadores nascidos na Capital ou em outros centros urbanos, não é superior à existente entre os operários de migração recente. Assim, a porcentagem de sindicalizados entre os Mod. é de $18 \%$, enquanto entre os Trad. ela atinge $20 \%$.

\begin{tabular}{|l|c|c|}
\multicolumn{2}{c}{ Tabela 39 (Operários) } \\
\hline Trabalhou na agricultura & Sindicalizados & Não sindicalizados \\
Não trabalhou na agricultura & $62 \%$ & $51 \%$ \\
& 38 & 49 \\
& $(100 \%)$ & $(100 \%)$ \\
& 13 & 49 \\
\hline
\end{tabular}

Quando se toma como ponto de referência a qualificação profissional, a porcentagem de sindicalizados é mais elevada entre os de qualificação superior (comparação entre ferramenteiros e operários comuns); quando se toma como ponto de referência o grau de urbanização em contraposição a trabalho anterior na agricultura, a porcentagem de

${ }^{5}$ Sara CHUCID e Michel LOWY: op. cit., Cf. também Henry A. LANDSBERGER, Manuel BARRERA e Abel TORO, The Chilean Labour Union Leader: A Preliminary Report on this Background and Attitudes, Industrial and Labour Review, Nova York, abril de 1964, reprint series n. ${ }^{\circ} 150$, e Walter GALENSON, (ed.) La Cima Obrara y el Desarrollo Económico, México, Editorial Limusa-Wiley, 1964. 
sindicalizados é mais elevada entre os entrevistados que trabalharam na lavoura e entre os que chegaram há pouco a São Paulo. O primeiro resultado era, até certo ponto, esperado. A formação profissional mais aprimorada indica período mais prolongado de aprendizagem e de trabalho no meio industrial e, consequentemente, supõe uma consciência profissional mais desenvolvida e melhores condições de ajustamento ao meio socioprofissional, que favorece a participação nas entidades associativas.

O segundo resultado, contudo, aparentemente contradiz as opiniões correntes que apontam o trabalhador originário de áreas tradicionais como mais refratário à participação nas atividades sindicais. Mas cabe indagar: Ser membro do sindicato tem o mesmo sentido para os setores acima indicados? Que representa o sindicato para os diversos setores operários? Infelizmente, as limitações da pesquisa não nos permitem oferecer uma resposta categórica a essas indagações. Porém, podem-se esboçar certas hipóteses através da discriminação de algumas tendências que transpareceram ao longo das entrevistas.

Inicialmente, deve-se ter em conta que, corroborando outras investigações, o sindicato é, para a grande maioria dos entrevistados, precipuamente, uma entidade assistencial, destinada a prover os associados de recursos médicos e orientação jurídica. A afirmação é válida tanto para os ferramenteiros como para os operários comuns; tanto para os trabalhadores nascidos em São Paulo como para os migrantes de áreas tradicionais. Ocorre, contudo, que para uns o sindicato é exclusivamente uma entidade assistencial enquanto, para outros, é também entidade de defesa de interesses socioeconômicos mais amplos e, pelo menos potencialmente, um instrumento de pressão. Ora, se o sindicato é entendido basicamente como órgão assistencial, a proporção relativamente superior de sindicalizados entre os trabalhadores vindos da agricultura não implica, necessariamente, consciência profissional mais desenvolvida, nem adesão a certos valores grupais. Aliás, a entrevista que transcrevemos quase integralmente no Capítulo I ilustra de modo típico a concepção que o trabalhador tem da associação profissional. As camadas operárias menos qualificadas tendem a privilegiar, entre as tarefas assistenciais, os serviços médicos e dentários. Este aspecto é particularmente acentuado entre os trabalhadores recém-chegados a São Paulo, enquanto os operários com mais experiência de vida urbana e, possivelmente, com mais experiência fabril, atribuem relativamente maior importância à assistência jurídica. Em outras palavras: estes últimos, embora não concebam a organização profissional em termos de órgãos de pressão coletiva, sabem utilizar melhor seus serviços na área da legislação trabalhista.

$$
\text { Tabela 40: "Por que o Sr. não é sócio do sindicato?”; }
$$

\begin{tabular}{|l|l}
\hline "Não há vantagem" & $32 \%$
\end{tabular}

"O sindicato não atende ao trabalhador"

"Nunca me interessei"

"O sindicato cria complicação"

"Não tenho necessidade do sindicato"

"A firma é boa não é preciso sindicato"

"O sindicato fica longe"

"A firma não gosta de gente sindicalizada"

"Não gosto de greves"

"Ainda não tive oportunidade de me sindicalizar"

"O sindicato dificulta a matricula"

"Sindicalizado ou não é a mesma coisa"

"O sindicato só trata de política"

$\mathrm{n}=$

\begin{tabular}{|c|}
$32 \%$ \\
14 \\
19 \\
7 \\
7 \\
5 \\
5 \\
3 \\
3 \\
3 \\
3 \\
3 \\
3 \\
$100 \%)$ \\
62 \\
\hline
\end{tabular}

OBS.: Porcentagens extraídas com base no número total de respostas.

O arrolamento dos motivos alegados pelos trabalhadores não sindicalizados para explicar por que não são sócios da associação profissional e, de outro lado, as razões apontadas pelos sindicalizados, são suficientemente ilustrativos. Na Tabela 40 estão as respostas à pergunta "Por que o senhor não é sócio do sindicato?". Intencionalmente, transcrevemos as respostas tal como foram oferecidas pelos trabalhadores, ainda que fosse possível classificá-las em categorias mais precisas e menos inclusivas.

Vê-se que pelo menos dois terços das respostas poderiam ser incluídas numa mesma categoria: "Não há vantagem em ser sindicalizado". Os entrevistados que apontaram um motivo preciso e determinado (como, por exemplo, "o sindicato só trata de política" ou "a empresa não gosta de gente sindicalizada") constituem uma minoria. No fundo, pela natureza da maioria das respostas, percebe-se que o sindicato é algo muito distante das preocupações e interesses da parcela majoritária dos informantes. 
Tabela 41: "Por que o Sr. é sócio do sindicato?"

"Pelos serviços médicos e dentários"

"Pela assistência jurídica"

"Porque o sindicato defende os nossos interesses"

"Porque o sindicato consegue aumentos de salários"

"Porque o sindicato consegue indenização"

Não frequenta, não sabe responder

$\mathrm{n}=$

$33 \%$

31

19

10

5
$100 \%$

OBS.: Porcentagens extraídas com base na sorna das respostas.

Os números acima falam por si e não caberia estender-se na explicitação da tabela. Ressaltemos unicamente que se pôde registrar, entre a minoria sindicalizada, 29\% de "respostas classistas", ou seja, de respostas que mencionam o sindicato não como entidade assistencial (assistência médica ou jurídica), mas como organização de defesa do proletariado. Os motivos que apresentam os trabalhadores para a sindicalização são congruentes com as principais vantagens que acreditam efetivamente encontrar na associação profissional, ou seja, serviços médicos e dentários e, depois, assistência ao trabalhador na Justiça do Trabalho.

Tabela 42: "Quais as vantagens que os sindicatos realmente oferecem aos trabalhadores?"

\begin{tabular}{|l|c|c|c|c|c|c|}
\hline & Sindicalizados & $\begin{array}{c}\text { Não } \\
\text { sindicalizados }\end{array}$ & Operários & Ferramenteiros & Mod. & Trad. \\
Assistência médica e & $61 \%$ & $25 \%$ & $32 \%$ & $42 \%$ & $48 \%$ & $79 \%$ \\
dentária & 43 & 25 & 25 & 42 & 38 & 16 \\
Serviços jurídicos & 22 & 18 & 22 & 12 & 5 & 37 \\
Aumentos de salários & 13 & 30 & 27 & 21 & 24 & 21 \\
Não oferece & 17 & 5 & 2 & 25 & 19 & 16 \\
vantagens & 4 & 3 & 5 & - & 5 & - \\
Defende os operários & 13 & 21 & 23 & 8 & 14 & 11 \\
Outras respostas & 23 & 61 & 62 & 24 & 22 & 20 \\
Não sabe & - & $4 \%$ & $4 \%$ & - & $5 \%$ & $5 \%$ \\
n = & & & & & & \\
Sem resposta & & & & & & \\
\hline
\end{tabular}

Obs.: Respostas múltiplas. Soma das porcentagens superior a 100\%. Porcentagens extraídas excluindo-se os que não responderam.

A elevada proporção de sindicalizados que apontou os serviços médicos como a principal vantagem que o sindicato oferece $(61 \%)$, em contraposição com a relativamente baixa frequência de respostas deste tipo entre os não sindicalizados $(25 \%)$ revela inequivocamente que a maior parte dos sindicalizados é associada ao sindicato com o objetivo nítido de usufruir desses serviços. Note-se, por outro lado, a proporção relativamente elevada de respondentes que não veem nenhuma vantagem na associação profissional. Está-se, pois, ante um grupo operário que concebe a organização sindical, em primeiro lugar, como um órgão de assistência e proteção ao trabalhador fora do âmbito das relações industriais e, em segundo lugar, como uma entidade destinada a obter aumentos gerais de salário. É certo que a orientação e o apoio jurídico prestado pelo sindicato ao trabalhador envolve um conjunto de questões que dizem respeito às relações entre o empregado e o empregador. Mas o aspecto importante é que a via jurídica para a obtenção das reivindicações significa retirar da associação sindical as atribuições de barganha direta com as empresas, de modo que as exigências operárias expressassem uma relação de força e de poder de pressão da entidade profissional. Reside aqui o aspecto central a ser ressaltado para a compreensão do sindicalismo e das relações industriais no Brasil. As leis de proteção ao trabalhador e os benefícios e vantagens concedidos ao proletariado brasileiro não são, fundamentalmente, resultado do fortalecimento das associações sindicais. Eles resultam, muito mais, de um lado, do aparecimento, com a industrialização, de uma nova categoria social, de sua pressão difusa e desorganizada sobre o Poder, da manipulação política dessas massas e, de outro lado, das necessidades objetivas da economia nacional no que tange à fixação do trabalhador à indústria e à formação de uma mão de obra tecnicamente mais aprimorada.

As observações anteriores não devem, por um lado, obscurecer o fato de que o sindicato, pelo menos para um setor minoritário do proletariado, é mais do que um mero órgão de assistência, de prestação de serviço, aparecendo também como uma associação de defesa dos interesses profissionais dos operários. Além disso, cumpre ter presente que o sindicato - embora como órgão assistencial - se configura para os trabalhadores como uma instituição operária, ou melhor, como algo que, se não lhes pertence inteiramente, serve-lhes de proteção. Nesse sentido, é necessário estabelecer alguns matizes que, até o momento, deixamos de lado no afã de destacar as atitudes mais gerais. As tabelas anteriores dão-nos certas indicações que necessitam ser ressaltadas, e que são reveladoras de uma imagem ligeiramente diferente que os diversos setores operários têm do sindicato. Em primeiro lugar, e possível perceber que os operários comuns, 
quando não ressaltam o cunho assistencial do sindicato, isto é, quando dão respostas "classistas", referem-se quase que unicamente a reajustamentos salariais. Em segundo lugar, é entre os ferramenteiros, ou seja, entre os grupos mais qualificados, que se encontram as porcentagens mais elevadas de respostas valorizando a associação profissional do ângulo de uma defesa geral dos interesses operários, expressão um tanto vaga, mas significativa. Este setor é capaz de entender o sindicato como algo mais do que um órgão de assistência médica, de assistência jurídica e de obtenção de reajustamentos salariais. Assim, na Tabela 40, apenas 2\% dos operários mencionaram, entre as vantagens do sindicato, a "defesa dos operários", enquanto entre os ferramenteiros a porcentagem de respondentes atingiu $25 \%$. Outros dados indicam a importância comparativamente maior que os operários semiqualificados atribuem à função de conseguir aumentos de salários. Em contrapartida, atribuições como "assistência ao trabalhador desempregado", "ajuda em época de greve", "formação de cooperativa de consumo", etc., são mencionadas com maior frequência pelos ferramenteiros.

\section{TIPOS DE ATITUDES ANTE O SINDICATO}

A partir das funções da associação profissional que são postas em relevo, é possível distinguir esquematicamente quatro tipos de atitudes que correspondem, respectivamente, às diferentes imagens que os diferentes setores operários formam do sindicato, e que implicam graus variados de comprometimento com a associação profissional e com a condição operária.

I. O sindicato como entidade de prestação de serviços médicos e dentários;

II. O sindicato como entidade de assistência jurídica;

III. O sindicato como meio para a obtenção de reajustamentos salariais;

IV. O sindicato como instrumento de luta e de defesa geral dos interesses sociais, econômicos e profissionais do trabalhador.

No primeiro tipo, assimila-se, predominantemente, o sindicato a uma instituição de assistência social caritativa. A adesão à organização profissional não significa aceitação dos valores e padrões do meio operário, nem tampouco a vontade de integração na categoria profissional e de reforçamento da coesão grupal. $\mathrm{O}$ trabalhador serve-se do sindicato como poderia utilizar-se dos serviços de outra entidade assistencial. Tipicamente, essas atitudes são encontradas nas camadas inferiores e mais desprotegidas do proletariado, que não dispõem, mesmo, de condições para buscar em outras instituições e serviços públicos ou privados a assistência social oferecida pelo sindicato. ${ }^{6}$

No segundo tipo, os serviços jurídicos postos à disposição dos associados pelo sindicato (orientação, conselhos e fornecimento de advogado) constituem, para o trabalhador, predominantemente, a principal atribuição da entidade profissional. Tipicamente, ela corresponderia a setores operários com maior experiência urbana, em condições de se aproveitarem das instituições e da legislação existentes não para fins assistenciais, mas como meio de obtenção de determinadas reivindicações ante a empresa. $\mathrm{O}$ sindicato apresenta-se como um instrumento a ser utilizado na perspectiva das ambições de melhoria de vida ou de ascensão social. O trabalhador "conhece seus direitos" assegurados pela legislação trabalhista e dela se vale contra a empresa. O elemento essencial aqui é que essa concepção do sindicato se relaciona com uma perspectiva individualista que não implica uma orientação para a integração no meio operário. A justiça trabalhista aparece como o meio por excelência para a obtenção da "reclamação" operária. Esta orientação implica, imediatamente, no deslocamento do conflito para fora da empresa e dificulta o aparecimento de padrões coletivos de ação no interior da fábrica.

Desde logo, o atendimento da reivindicação passa a depender de seus fundamentos legais (definidos pela Justiça do Trabalho) e não do poder de pressão do sindicato ou do grupo operário. $\mathrm{O}$ trabalhador não está interessado no fortalecimento do sindicato enquanto associação de classe, nem no aumento eventual de seu poder de pressão sobre a camada empresarial. Trata de aproveitar em seu benefício pessoal as disposições e instituições legais que o Estado criou. $\mathrm{O}$ contacto com o sindicato não envolve nenhum comprometimento associativo mais profundo.

No terceiro tipo, o sindicato não aparece fundamentalmente como um órgão encarregado do fornecimento de assistência médica ou jurídica, mas como um instrumento de reivindicação salarial. O importante é que essa atitude envolve um comprometimento mais acentuado com o sindicato,

${ }^{6} 79 \%$ dos trabalhadores recentemente chegados a São Paulo, contra $48 \%$ dos nascidos na capital ou em outros centros urbanos importantes, apontaram a assistência médica como a principal vantagem oferecida pelo sindicato. 
que não é visto unicamente como uma instituição que deve prestar auxílio ao trabalhador fora da esfera da relação de trabalho e da produção. Mas a compreensão das funções sindicais não ultrapassa o nível econômico. Em outras palavras: as eventuais funções do sindicato no plano socioprofissional não chegam a integrar a constelação de reivindicações dos trabalhadores. Enfim, entende-se a organização sindical ao nível da luta reivindicatória mais elementar da defesa do salário. Esse tipo de atitude sugere um grupo operário para o qual as questões relativas ao meio socioprofissional ocupam lugar secundário, fato indicativo, por sua vez, de baixos níveis de qualificação profissional, de baixos salários. Mas sugere, de outro lado, um grupo cujas esperanças de escapar à "condição operária" reduziram-se, tendo o projeto de ascender socialmente cedido lugar ao de melhorar de vida no interior da própria classe.

O quarto tipo de atitude ante o sindicato implica na compreensão da organização profissional num sentido mais amplo de proteção do trabalhador que não se restringe ao fornecimento de assistência médica ou jurídica e que ultrapassa a concepção da organização sindical como restrita apenas à obtenção de reajustamentos salariais. Esse tipo de atitude, como notamos, há pouco, manifesta-se de modo mais claro entre os ferramenteiros. Pode-se perceber, aqui, uma visão da associação sindical estruturada a partir de funções mais amplas de defesa do trabalhador, não apenas no que toca à elevação salarial, mas também no que tange a outros aspectos socioprofissionais. É significativo observar que $17 \%$ dos ferramenteiros mencionaram como uma das principais atribuições do sindicato a assistência ao trabalhador em época de greve (contra apenas $2 \%$ dos operários comuns) e que $12 \%$ (em comparação a $6 \%$ dos operários) fizeram referência à assistência em período de desemprego.

Porém, os ferramenteiros encontram-se numa situação ambígua. Se é entre eles que a imagem do sindicato mais se aproxima de uma organização reivindicativa, de um instrumento geral de luta e defesa ante o poder patronal, por outro lado, formam eles o grupo menos pressionado por fatores econômicos e profissionais a recorrer ao sindicato. Caberia, assim, indagar por que razão se encontram exatamente entre os setores mais qualificados as taxas mais elevadas de sindicalização. Não são esses setores os que percebem salários mais elevados e os que se mostram mais satisfeitos com as condições de trabalho? Walker e Guest, examinando as razões comumente oferecidas para explicar o apoio dos operários norte- americanos ao sindicato, levantam a hipótese de que o sindicato preenche quando as exigências básicas dos trabalhadores já se encontram atendidas necessidades de ordem psicológica e emocional, de segurança e de garantia ante o poder patronal, que ultrapassam a função de defesa de interesses econômicos e materiais imediatos e manifestos. ${ }^{7}$ Não temos, infelizmente, condições de examinar mais a fundo a hipótese dos autores norteamericanos e não saberíamos dizer, com precisão, em que extensão ela poderia ser válida para os ferramenteiros da Empresa Automobilística. Apesar disso, chama-nos a atenção para um ponto importante. A sindicalização, mesmo para os grupos operários melhor situados na escala de remuneração, implica, de algum modo, a afirmação ante a empresa de uma autonomia operária, uma espécie de desafio à autoridade patronal. Para os ferramenteiros, a nosso ver, ela significa conjuntamente a afirmação de um orgulho profissional e uma forma de proteção eventual contra a empresa, o que se adapta bem à "consciência corporativista" dessa categoria. Menos oprimidos pelos baixos salários, mais integrados ao meio fabril, os ferramenteiros chegaram a ter do sindicato uma imagem, vaga é verdade, que se aproxima da do sindicalismo dos países desenvolvidos. Mas a organização sindical brasileira, tal como foi imaginada e aplicada pelo Estado, não motiva especialmente os trabalhadores mais qualificados. Os aspectos sociais gerais do trabalho encontram-se regulamentados pela legislação trabalhista, enquanto a questão dos níveis salariais é tratada em conjunto quando dos acordos coletivos, sem que os problemas específicos que dizem respeito mais diretamente às categorias qualificadas sejam considerados.

Os quatro tipos de atitudes que distinguimos são construções típicas, elaboradas com objetivos analíticos. É desnecessário insistir que essas atitudes não se encontram nitidamente cristalizadas no grupo. A utilidade da construção advém dos recursos que pode oferecer à análise. Serve na medida em que permite salientar o significado que assume o sindicato para os diversos setores operários. Entendem-se, destarte, resultados aparentemente paradoxais. De um lado, índices mais elevados de sindicalização entre os ferramenteiros em comparação com os operários

\footnotetext{
${ }^{7}$ As razões alinhadas pelos sociólogos americanos são as seguintes: 1) salários; 2) estabilidade no emprego; 3) horas; 4) condições de trabalho; 5) abuso de autoridade por parte dos mestres e de outros supervisores; 6) atos de discriminação da empresa contra operários por motivos raciais ou de filiação partidária ou sindical. Charles R. WALKER e Robert H. GUEST, The Man on the Assembly Line, pp. 132 e 133.
} 
semiqualificados; de outro, índices mais elevados de sindicalização entre os trabalhadores recém-chegados a São Paulo, em contraposição aos aqui nascidos, contrariando o que comumente se afirma. É que, em cada grupo operário, a sindicalização tem significado diferente. Se, no caso de trabalhadores qualificados, a sindicalização resulta de maior ajustamento ao meio operário e expressa de algum modo uma consciência grupal ou profissional, no caso dos não qualificados a sindicalização significa a busca de proteção e de auxílio pessoal, sem que seja necessariamente indício de maior integração ao meio fabril ou que o sindicato seja considerado instrumento de luta. Esses aspectos merecem ser destacados porque, algumas vezes, tende-se a ver, no simples fato da sindicalização, a expressão de uma "consciência grupal", de um desejo de integração ao meio operário ou mesmo de uma "consciência anticapitalista". Parece claro que o sindicato adquire variada significação para cada setor operário e, mesmo quando e percebido como organismo de reivindicação, a consciência sindical pode alimentar-se de fatores diferentes, como a defesa profissional, a resistência ao autoritarismo patronal (expresso ao nível da empresa), as reivindicações salariais, etc.

As análises anteriores que buscaram estabelecer os diferentes tipos de atitude ante a organização sindical e os matizes introduzidos entre as categorias profissionais no interior do grupo estudado não devem fazer esquecer o traço essencial que caracteriza, neste aspecto, os trabalhadores da Empresa Automobilística: o sindicato ocupa lugar de medíocre importância nas atividades, preocupações e interesses dos operários.

E não será demais relembrar que a taxa de sindicalizados é extremamente baixa e que, entre os sindicalizados, a grande maioria não frequenta o sindicato.

\section{O PROLETARIADO, A EMPRESA E O SINDICALISMO}

Nesta altura da exposição, uma pergunta se impõe: A que se deve a fraca proporção de sindicalizados e o desinteresse quase total pelas atividades associativas entre os trabalhadores estudados? A resposta exige para fins da análise a separação de três ordens de fatores relacionadas as características: I) do proletariado brasileiro; II) da Empresa Automobilística e III) do sindicalismo brasileiro.
I) As primeiras já se fez menção no Capítulo I, mas convém sintetizálas aqui. Lidamos com uru proletariado de formação recente, originário de diferentes áreas do país, com experiências profissionais anteriores bastante diversificadas. No caso da empresa estudada, estes traços se apresentam de modo particularmente nítido. Trata-se de um grupo heterogêneo, tanto no que diz respeito à origem social, quanto no que se relaciona ao passado profissional. Falta uma tradição operária tanto para os trabalhadores que imigraram da agricultura como para aquela parcela minoritária de trabalhadores nascidos em centros urbanos de relativa importância. A grande maioria (63\%) dos operários entrevistados descendia de lavradores (pequenos proprietários, parceiros ou assalariados agrícolas). Mesmo entre os nascidos em São Paulo ou outros centros urbanos (Mod.) a porcentagem de entrevistados cujos pais eram trabalhadores industriais é bastante baixa (18\%). Seria desnecessário insistir sobre os efeitos negativos da mobilidade sócio-ocupacional para a integração e participação do indivíduo num dado grupo e, no que se refere especificamente ao proletariado, para a participação nas atividades sindicais. A continuidade da experiência profissional tende a estimular a participação nas atividades associativas, na medida em que possibilita a sedimentação de uma "subcultura" profissional ou de classe e na medida em que os interesses individuais identificam-se com os da categoria profissional ou da classe. ${ }^{8}$

Faz-se mister, por outro lado, relembrar o projeto de ascensão social ou de melhoria de vida que anima o grupo investigado, e os motivos que o levaram à Empresa Automobilística. Este ponto merece novas considerações. É comum a referencia ao projeto de ascensão social que estimula as migrações dos trabalhadores das áreas parcamente industrializadas para os centros fabris ou a transferência da mão de obra do campo para as cidades. Porém, pelo menos quando se trata de grandes empresas, em que os salários sobrepassam a média vigorante no conjunto do parque industrial, encontra-se também no trabalhador nascido nos

\footnotetext{
${ }^{8}$ Uma confirmação empírica das afirmações anteriores encontra-se em Lipset e Gordon Utilizando dados de entrevistas realizadas pelo Institute of Industrial Relations com 953 assalariados em Oakland (1949-50), os autores concluem que a mobilidade vertical, qualquer que seja a sua direção, contribui para dificultar a participação dos operários nas organizações sindicais. Seymour Martin LIPSET e Ioan GORDON: "Mobility and TradeOrganizaçoes sindicais. Seymour Martin LIPSET e loan GORDON: "Mobility and Tradeand Power, The Free Press of Glencoe, 5. ${ }^{\text {a }}$ ed., 1961.
} 
centros urbanos (e, às vezes oriundos de famílias operárias) as mesmas motivações e aspirações de melhoria de vida ou de ascensão social que impelem os migrantes da agricultura. Dada a rapidez da expansão do parque industrial paulista nos últimos anos e seus efeitos na formação da classe operária, não parece adequada a imagem do proletariado atual como segmentado em dois setores, um deles mais antigo, composto de trabalhadores "ajustados" ao meio fabril, possuidores de uma tradição operária, com experiência sedimentada de lutas sindicais, agressivos e organizados, e o outro, composto de trabalhadores de origem agrícola, sem experiência de vida urbana nem de vida associativa, e cuja presença no mercado de trabalho enfraqueça a capacidade reivindicatória das categorias anteriores. Certamente é possível encontrar grupos operários que expressem tipicamente tais situações polares. Mas não parece ser este o traço essencial a caracterizar a situação do proletariado paulista. Efetivamente, em São Paulo pelo menos, tal quadro só seria adequado para o período que medeia a Primeira e a Segunda Guerra Mundial, isto é, quando o proletariado de origem estrangeira começou a ser substituído pelo trabalhador nacional, quando se enfraqueceram as correntes migratórias externas e ampliaram-se os deslocamentos das populações de outros Estados para São Paulo. Nesta fase, seria possível traçar uma divisão relativamente nítida entre dois setores operários. A partir de então, a continuidade do processo de industrialização vem significando a incorporação quase constante de novas levas de trabalhadores ao parque fabril paulista. Neste contexto, mais do que por uma separação em dois setores, o proletariado paulista (e também brasileiro, ao que tudo indica) se caracteriza por ser uma classe em processo de formação, em que novas massas vêm sucessivamente se acrescentar a camadas ainda não consolidadas, em que os setores que poderíamos denominar "de velha tradição operária" constituem parcela extremamente pequena.

Habitualmente ressalta-se apenas a inexperiência sindical e profissional do trabalhador oriundo da agricultura e assim tende-se a atribuir uma importância desproporcional aos efeitos de sua presença na determinação das orientações sindicais, profissionais e valorativas no conjunto das camadas operárias. É-se levado a responsabilizar esses efetivos pela ausência de coesão grupal pelos baixos índices de sindicalização, etc. Mas cumpre ter em conta que não apenas os setores "de origem operária" são extremamente minoritários como também estão lançados numa perspectiva de ascensão social. A mão de obra industrial paulista não e composta unicamente de trabalhadores vindo da agricultura ou de trabalhadores de famílias operárias. Uma proporção ponderável do proletariado industrial é recrutada dos setores terciários ou de atividades econômicas marginais nas grandes cidades; esses, embora contando com uma experiência de vida nos grandes centros, são quase tão desprovidos de verdadeira formação profissional e de uma "tradição operária" quanto os ex-lavradores. Por outro lado, os operários industriais das pequenas cidades do interior - como ressaltamos no Capítulo I - que se dirigem para a capital e para as grandes empresas estão igualmente movidos por um projeto de melhoria de vida. A rotatividade profissional, a medíocre fixação à indústria, é característica geral do proletariado paulista e de outros centros de industrialização recente.

II) A segunda ordem de fatores que cumpre examinar é a que opera no âmbito da Empresa Automobilística. Pensamos mais exatamente na combinação, ou na interação das características da empresa com as do proletariado, tal como vimos de descrever. As orientações e valores que modelam o comportamento do grupo investigado, Obviamente, não decorrem apenas de fatores cujas origens podem ser localizadas no plano da sociedade global. As respostas dos entrevistados, em grande parte, são condicionadas pela situação de trabalho numa empresa determinada, isto é, por fatores mais particulares, tal como as atitudes ante a própria empresa, estão, por sua vez, determinadas pelas características gerais da classe, ou seja, por fatores exógenos à situação de trabalho.

$\mathrm{O}$ aspecto significativo e a conjunção e adequação entre as duas ordens de fatores, entre os que operam ao nível da classe e os que operam ao nível da empresa. Mais concretamente: as características da Empresa Automobilística são tais que concorrem eficazmente para estimular formas de comportamento e atitudes já existentes no proletariado de modo a constituir poderoso obstáculo para a integração sindical e para a emergência de "condutas classistas". Empregar-se na Empresa Automobilística, no caso, significa precisamente a realização das ambições que animam o proletariado: salário mais elevado, melhores condições de trabalho, possibilidades de promoção e de aquisição de uma profissão. Neste contexto, fica clara a pequena importância atribuída ao sindicato enquanto instrumento de pressão. Na realidade, do prisma das aspirações básicas dos trabalhadores e do modo como são equacionadas pela e na Empresa Automobilística, o sindicato aparece como uma instituição desnecessária, a 
não ser em suas funções médicas e jurídicas. Para a sedimentação dessa atitude concorre o fato de que as vantagens que são salientadas pelos trabalhadores não derivaram de uma ação dos próprios operários, não foram frutos de uma pressão sindical, sendo, efetivamente, não uma conquista operária, mas o resultado de um processo de expansão industrial pelo qual os trabalhadores não se sentem responsáveis. Nota-se aqui o flagrante contraste entre as conquistas sociais, sindicais e econômicas do proletariado norte-americano, francês, inglês, etc., em que cada vantagem obtida - do reconhecimento da organização sindical aos aumentos salariais - esteve estreitamente vinculada à capacidade de pressão e de barganha dos grupos operários. Mas, pode-se indagar, numa estrutura de dominação, como é a empresa, em que os operários estão inteiramente afastados do poder de decisão, de influencia e de controle sobre a organização, em que os interesses da companhia e seus objetivos frequentemente colidem com os dos trabalhadores, não se cristalizam condições objetivas para conflitos que propiciem a necessidade da organização operária e estimulem a integração sindical dos trabalhadores?

III) A consideração desta questão conduz à terceira ordem de fatores relacionada às características específicas do sistema associativo profissional no Brasil. Não caberia, neste ponto, uma apreciação mais demorada do sindicalismo brasileiro, de suas vinculações com o Estado, da legislação trabalhista, etc. À luz do que foi dito anteriormente, o aspecto que nos interessa ressaltar é o que diz respeito ao sindicato em suas relações com a empresa. Sem nos preocuparmos, pelo momento, com seus possíveis efeitos sobre a "combatividade operária", um dos resultados (nem sempre tido devidamente em conta) da legislação sindical e social rio Brasil foi praticamente a eliminação da organização sindical do interior das indústrias. Isso se fez por vias indiretas, não só porque a Justiça do Trabalho se interpôs entre empregados e empregadores, mas também porque o próprio Estado avocou a si um poder de decisão, nesta área, que tornou quase desnecessário tanto o estabelecimento de relações e contactos diretos entre o sindicato e as direções das empresas como o contrato coletivo de trabalho. Do momento em que os reajustamentos salariais, a fixação do salário mínimo e outras leis sociais (como o projeto sobre a estabilidade no emprego) são de alçada do Executivo Federal, a orientação das reivindicações sindicais desvia-se do plano da empresa para o do governo, substituindo-se os interlocutores. Neste contexto, o nível salarial e as vantagens obtidas pelo proletariado apenas indiretamente refletem seu poder de barganha ante a empresa, embora possam refletir seu poder de pressão sobre os poderes públicos.

A vinculação com o Estado, implicando contactos e entendimentos com os detentores do Poder (grupos, partidos e líderes), envolve, como não poderia deixar de ser, um componente político. Os sindicatos, através de suas lideranças, expressam as posições de uma parcela do eleitorado, de modo que a obtenção de determinadas vantagens e benefícios trabalhistas efetua-se por intermédio de um complexo mecanismo político-partidário que exclui a barganha direta entre empresários e operários estribada em posições de força; diminui, pois, a importância da mobilização sindical como meio de lograr o atingimento das reivindicações operárias já que, às vezes, a via eleitoral se oferece como a mais factível para uma população operária instável e heterogênea. A luta pela obtenção de reivindicações profissionais e econômicas do proletariado tende, assim, a escapar dos quadros da ação sindical para assumir feições políticas mais gerais. Se temos em conta a vinculação da estrutura sindical ao aparelho estatal e o fato de que, frequentemente, os problemas econômicos e sociais mais amplos preponderam sobre as exigências profissionais específicas, têm-se aí os ingredientes para a configuração de um "sindicalismo político", mais preocupado com os problemas gerais da nação do que com as reivindicações derivadas da situação de trabalho fabril. As aspirações operárias vinculam-se e identificam-se com as de outras camadas populares. O sindicato, quando atua politicamente, faz-se implícita ou explicitamente porta-voz não só de uma categoria profissional, mas também das camadas inferiores no seu conjunto. A ideologia do "sindicalismo político" não é manifestamente anticapitalista, mas nem por isso deixa de situar a problemática de modificações estruturais: democratização do poder, reforma agrária, nacionalismo, desenvolvimento econômico, justiça social, etc. ${ }^{9}$ A vinculação das possibilidades de melhorias nas condições de vida da classe a um processo geral de transformação social indica uma profunda

${ }^{9}$ Cf. Leôncio Martins RODRIGUES, Conflito Industrial e Sindicalismo no Brasil, III Parte "Do Anarquismo ao Nacionalismo - Transformações no Comportamento Operário" (especialmente pp. 191 a 202). No mesmo sentido vão as observações de Henry LANDSBERGER referentes ao sindicalismo latino-americano. Cf. "La Elite Obrera de América Latina y La Revolución”, in: S. M LIPSET e A. SOLARI, Elites y Desarrollo em América Latina, Buenos Aires, Paidos, 1967. 
desconfiança, por parte dos setores politicamente ativos do proletariado, quanto à capacidade dos grupos empresariais de promoverem a expansão econômica. Tais aspectos nem sempre se manifestam no sindicalismo brasileiro. Só se configuram com mais nitidez quando os sindicatos adquirem relativa liberdade de expressão e ação. Os esforços do patronato não seria preciso dizer - vão no sentido de reduzir o papel dos sindicatos à representação estrita dos interesses dos trabalhadores na área profissional definida pela legislação trabalhista.

Orientado para os problemas gerais da nação e não contando com o apoio ativo de amplos setores operários, o sindicalismo brasileiro abdicou da pretensão de desempenhar qualquer papel de importância no interior da empresa. Aqui, possivelmente, reside uma das diferenças mais marcantes entre o sindicalismo brasileiro e o dos países desenvolvidos. Nestes últimos, após as fases iniciais de constituição do industrialismo, em que o movimento operário buscou afirmar-se como pura negatividade, o sindicalismo validou sua existência, situou novas metas prioritárias. Neste sentido, uma parte de seus esforços destina-se à obtenção de maior controle sobre as condições de trabalho, de emprego e de organização das empresas, ou seja, de redução do poder patronal.

O que é importante em relação a esses militantes orientados por novas realidades já não é a propriedade coletiva dos meios de produção (quando o Estado em muitos países nacionalizou amplos setores da economia), mas o "poder de decisão", quer dizer, a criação e o controle de ligação entre a base e a direção de uma empresa. Essas tendências inovadoras são ainda mais marcadas no sindicalismo italiano, onde a CGIL, ao realizar vigorosas ações de reivindicação, específicas de uma região, de uma indústria e, inclusive de uma fábrica, acentuou a luta pelo poder de decisão na empresa e na nação: orientação manifestada por seu interesse ativo na utilização racional do progresso técnico, por sua participação (sem má consciência "reformista") no estudo de problemas atuais da Itália, do crescimento econômico, da programação a longo prazo e particularmente da distribuição ótima, na empresa, das futuras inversões em bens de capital e em remuneração. ${ }^{10}$

\footnotetext{
${ }^{10}$ G. FRIEDMANN, “Tendencias de Hoy, Perspectivas de Mariana”, in: G. FRIEDMANN e P. NAVILLE, Tratado de Sociologia del Trabajo, vol. II, p. 376. Sobre o assunto, consultese igualmente: P. SANTI, "Les Syndicats et la politique de controle des salaires", Les Temps
}

Essa tendência manifesta-se de diferentes maneiras no movimento sindical contemporâneo, ainda que as ideologias que a envolvam possam ser diversas. Trata-se de uma resposta operária à "lógica do lucro", ao poder da empresa de dispor da produção e dos homens segundo uma racionalidade que se choca com as aspirações operárias de autonomia, e liberdade no trabalho e de afirmação profissional. Esta é uma dimensão do sindicalismo que leva à superação de uma posição defensiva e, algumas vezes, puramente negativa, de defesa da profissão, das condições de trabalho e do nível econômico. ${ }^{11}$ Esta orientação do movimento sindical, que põe em causa o poder de decisão patronal, implica o reforçamento da ação sindical ao nível da organização industrial. Na Empresa Automobilística - como aliás na maioria das fábricas brasileiras - o sindicato praticamente inexiste e não tem condições para interferir em questões tais como: classificação profissional, formas do pagamento, admissão e dispensa de empregados, ritmo de trabalho, relações com a supervisão, etc. Ocorre que esses tópicos estão vinculados com uma problemática social e profissional mais ampla e,

Modernes, Paris, agristosetembro de 1964; B. TRENTIN, "Les syndicats italiens et le progres technique", Sociologie du Travail, Paris, abril-junho de 1962; R. DAHRENDORF, "Poli- tique syndical et structure des entreprises en Alemagne", Sociologie du Travail, abriljunho de 1962; T. TOPHAN, "Shop Steward, ContrOle Ouvrier et Syndicats", Les Temps Modernes, Paris, agristo-setembro de 1964.

${ }^{11}$ Uma vez que a redução da miséria e a ampliação dos níveis de consumo das populações operárias, nos países desenvolvidos, enfraqueceu substancialmente o potencial revolucionário e mobilizador dos apelos sindicais e socialistas clássicos, isto é, organizados em torno da denúncia da pobreza proletária, alguns autores socialistas atuais veem, no esforço para a redução da autoridade patronal, a base para a renovação da militância operária e para a estimulação da luta socialista nas condições do neocapitalismo. Assim, escreve Gorz, partindo das novas orientações do comportamento operário ante a empresa: "Trata-se (...), para o movimento operário, de reivindicar o poder permanente de determinar contratualmente todos os aspectos da relação de trabalho e os critérios de remuneração, de maneira que toda modificação no processo produtivo deva ser negociada com ele e que ele possa, então, influir sobre a política de gestão da empresa e a orientar num sentido desejado". Nesse sentido, o autor aponta as seguintes reivindicações específicas: I) Controle, pelo sindicato, das escolas de aprendizagem; II) controle da organização do trabalho e do modo de distribuição de postos. (“... para assegurar que as mudanças de postos e as modificações na organização se façam no sentido do desenvolvimento das faculdades e de autonomia profissional dos trabalhadores...); III) $\mathrm{O}$ controle, pelo sindicato, da divisão do trabalho, ao nível da empresa e do ramo, em função das técnicas de produção e de sua evolução previsível; IV) Negociações das cadências ou dos ritmos de trabalho, dos salários por peça, da qualificação dos postos e funções, dos horários, etc. André GORZ, Stratégie Ouvrière et Neo-capitalisme, Paris, Seuil, 1964, pp. 45 e 46. 
em seu significado mais profundo, evidenciam aspirações operárias que manifestam o desejo de uma maior participação nas decisões tanto no âmbito da empresa quanto no da sociedade industrial. Em outras palavras: indicam uma orientação da ação operária que expressa a vontade de interferir nos rumos da sociedade. Nas condições de formação do proletariado brasileiro, as atitudes ante o trabalho industrial e a importância que assume a reivindicação salarial acarretam o desinteresse pelas questões socioprofissionais e pelos problemas relacionados aos mecanismos de participação nas decisões e de restrição do poder patronal.

\section{URBANIZAÇÃo E SINDICALIZAÇÃO}

Tem sido enfatizada, nos estudos sobre a classe operária brasileira, a presença de valores e formas de comportamento trazidos do meio rural. A eles atribui-se, em parte, a dificuldade encontrada na incorporação sindical dos trabalhadores originários da agricultura. Nas áreas pré-industriais da sociedade brasileira, as ações coletivas estruturar-se-iam com base em relações primárias, o que dificultaria, no meio urbano, o estabelecimento de laços de solidariedade fundados em relações secundárias e, consequentemente, a participação nas atividades do sindicato. Não se pretende aqui rejeitar pura e simplesmente uma elaboração teórica baseada nos esquemas dicotômicos tradicionalismo-modernismo que podem, afinal, constituir instrumentos úteis para a análise. Mas cumpre não esquecer, em primeiro lugar, que normas e valores tradicionais resultam de um dado tipo de estruturação socioeconômica no interior da qual guardam certa funcionalidade. Se vigoram em outro contexto social - definido tipicamente como regido por padrões racional-burocráticos - a investigação sociológica necessita examinar quais os fatores que permitem sua sobrevivência no novo meio, no qual, por definição, seriam disfuncionais. Certamente, é possível supor, quando a análise incide sobre a conduta de grupos humanos em processo de mobilidade (pensamos nos casos de migrações maciças de mão de obra de áreas rurais tradicionais para outros contextos socioeconômicos) que valores e normas, adequados ao meio social anterior, possam dificultar o ajustamento ao novo ambiente, com todas suas consequências no comportamento do indivíduo ou do grupo. Mas cabe indagar sobre as possibilidades de sobrevivência de tais normas em contextos tipicamente diferenciados e em que medida não tendem a dar lugar a outros valores e normas, ou a outros tipos de conduta mais aptos a responder às exigências de novos requerimentos sociais e profissionais. A possibilidade de persistência depende, em última instância, do grau de sua adequação à nova estrutura, pois, do outro modo, no limite, o indivíduo não poderia preencher os papéis e funções criados pela sociedade urbana. $\mathrm{Na}$ verdade, o que ocorre não é precisamente a persistência de valores e modos de comportamento tradicionais, mas sua reformulação sob o impacto de novos requisitos. Mais concretamente: o migrante oriundo do meio rural, que se fixa nos grandes centros urbanos, que busca a efetivação de aspirações de ascensão social ou de melhoria de vida, que deseja para seus filhos uma carreira e que valoriza a educação como meio de obter um status superior, está ainda inteiramente orientado por normas de uma cultura tradicional? É possível aceitar que, no tocante às atitudes ante o sindicato e ao grupo de trabalho, persiste o comportamento tradicional, acarretando o enfraquecimento da solidariedade profissional. Porém, por que o trabalhador de origem agrícola conduz-se "tradicionalmente" neste terreno e "racionalmente" em outros? E a indagação conduz à investigação para o contexto social, as estruturas políticas, e os múltiplos outros fatores que permitem a manutenção de modos tradicionais de comportamento no interior da ordem industrial. Nestas condições, deve-se localizar em elementos sociais mais amplos (como o sistema sindical brasileiro, o modo de formação da classe, os projetos que motivam o ingresso na indústria, etc.) as razões da pequena participação nas atividades sindicais e da fraca solidariedade profissional. Assim, se formas de conduta e uma visão tradicionalista do mundo se mantém com certo vigor é porque elas encontram nos fatores acima apontados terrenos propícios para sua sobrevivência.

Em segundo lugar, faz-se mister relembrar que o baixo índice de sindicalização não é de modo algum atributo exclusivo dos operários originários da agricultura. Também para as categorias operárias educadas no meio citadino o sindicato não se apresenta essencialmente como uma organização de pressão e de combate. Em muitos casos, os trabalhadores com mais experiência de vida urbana e dotados de qualificação educacional e profissional relativamente superior procuram explorar, de uma perspectiva individual, essas vantagens na competição com os setores menos qualificados. Esta afirmação não significa dizer que as camadas operárias "mais urbanizadas", porém de baixa qualificação profissional, igualmente, se mostrem tão refratárias à participação política como os setores de 
migração recente. Mas aqui cumpre distinguir uma participação política (quer seja medida pelo mero ato de votar, pela presença em comícios, em atividades partidárias ou simplesmente por um interesse exclusivamente informativo sobre os fatos da política nacional) e uma participação sindical. Os setores operários "mais urbanizados" podem, de um modo geral, mostrar-se mais receptivos à participação política sem que ela se acompanhe de um interesse maior pelas atividades sindicais. Além disso, sua atividade política pode perfeitamente não se caracterizar como uma "participação operária", isto é, classista-profissional, mas como uma participação "popular". Nessas circunstâncias, teríamos formas de participação política operária não relacionada a uma problemática profissional e "classista" e os elementos estimuladores não derivariam do meio industrial, mas do meio urbano, de aspirações e exigências do trabalhador enquanto cidadão.

Efetivamente, nas investigações na Empresa Automobilística nada indica que os setores mais urbanizados demonstrem uma orientação mais "classista" em suas atitudes ante a empresa e à sociedade. Duas perguntas, relativas às atitudes ante a greve, dão-nos indicações neste sentido.

Tabela 43: "Quando os trabalhadores desejam um aumento de salário e não conseguem, o Sr. acha que eles devem entrar em greve?"

\begin{tabular}{|c|c|c|c|c|c|c|}
\hline & Sindicalizados & Não sindicalizados & Operários & Ferramenteiros & Mod. & Trad. \\
\hline Não & $17 \%$ & $47 \%$ & $42 \%$ & $33 \%$ & $45 \%$ & $35 \%$ \\
\hline Sim & 44 & 32 & 35 & 33 & 32 & 45 \\
\hline Depende & 35 & 19 & 21 & 30 & 23 & 20 \\
\hline \multirow[t]{2}{*}{ Não sabe } & 4 & 2 & 2 & 4 & - & - \\
\hline & $(100 \%)$ & $(100 \%)$ & $(100 \%)$ & $(100 \%)$ & $(100 \%)$ & $(100 \%)$ \\
\hline $\mathrm{n}=$ & 23 & 63 & 62 & 24 & 22 & 20 \\
\hline \multicolumn{7}{|c|}{$\begin{array}{l}\text { Tabela 44: "Os operários acham que as greves } \\
\text { podem ajudar a melhorar a situação deles?" }\end{array}$} \\
\hline Não & $\begin{array}{l}\text { Sindicalizados } \\
\quad 30 \%\end{array}$ & $\begin{array}{c}\text { Não sindicalizados } \\
45 \%\end{array}$ & $\begin{array}{l}\text { Operários } \\
44 \%\end{array}$ & $\begin{array}{l}\text { Ferramenteiros } \\
33 \%\end{array}$ & $\begin{array}{l}\text { Mod. } \\
50 \%\end{array}$ & $\begin{array}{l}\text { Trad. } \\
35 \%\end{array}$ \\
\hline Sim & 44 & 30 & 35 & 30 & 18 & 45 \\
\hline Depende & 22 & 22 & 18 & 33 & 32 & 20 \\
\hline \multirow[t]{2}{*}{ Não sabe } & 4 & 3 & 3 & 4 & - & - \\
\hline & $(100 \%)$ & $(100 \%)$ & $(100 \%)$ & $(100 \%)$ & $(100 \%)$ & $(100 \%)$ \\
\hline $\mathrm{n}=$ & 23 & 63 & 62 & 24 & 22 & 20 \\
\hline
\end{tabular}

Os dois quadros requerem um exame mais cuidadoso. Lembremos, antes de mais nada, que traduzem opiniões dos entrevistados e nada informam sobre o comportamento efetivo das diversas categorias. Contudo, malgrado essa restrição, a nosso ver, não deixam de prestar informações para a interpretação das atitudes dos respondentes ante a greve. A primeira observação a ser feita incide sobre a porcentagem relativamente elevada de trabalhadores que, em ambas as tabelas, rejeitam peremptoriamente a greve como instrumento para a obtenção de suas reivindicações. $O$ dado significativo, aqui, é que as opiniões mais hostis à greve encontram-se precisamente entre os trabalhadores mais urbanizados (Na tabela 44, 50\% dos Mod. responderam taxativamente que as greves não contribuem para a melhoria da situação dos operários contra 35\% dos Trad.) Por outro lado, os sindicalizados, em comparação com os não sindicalizados, ofereceram índices mais elevados de opiniões positivas a respeito da greve.

Qual o significado ou o sentido das diferenças observadas nas respostas das diversas categorias? Infelizmente, os limites da pesquisa não permitem oferecer respostas mais categóricas nesta área. Contudo, uma vez que algumas tendências e orientações se repetem em diferentes tabelas, parece possível destacar certas indicações que devem ser aceitas com as reservas apontadas e que valem, ao mesmo tempo, como hipóteses para futuras investigações sobre o comportamento dos grupos operários. Assim, parece que a urbanização não se encontra relacionada com atitudes $e$ opiniões favoráveis ao sindicato, nem serve tampouco como índice revelador de maior predisposição para a integração sindical e para a participação nas atividades do grupo. Esta mesma observação já a havíamos feito quando da análise das taxas de sindicalização. Outras investigações, é certo, tem evidenciado a correspondência entre a participação sindical e o tempo de vivência em centros urbanos. ${ }^{12}$ Mas a urbanização geralmente significa outros atributos, como nível educacional e profissional superior à média da população operária e, quase sempre, mais tempo de permanência na indústria e na profissão. Quando as pesquisas incidem sobre as lideranças sindicais geralmente se encontram proporções elevadas de dirigentes nascidos em centros urbanos ou vivendo em cidades grandes há bastante tempo. Julgamos que há relações estatísticas, de coincidência entre os dois fenômenos (urbanização e sindicalização), mas não relações causais. Quando os setores urbanizados dispõem de nível educacional superior aos grupos de trabalhadores originários de áreas ${ }^{12}$ Por exemplo, as pesquisas já citadas de Michel LOWY e Sara CHUCID, no Brasil, e a de
Henry LANDSBERGER, Manuel BARRERA e Abel TORO, no Chile. 
pré-capitalistas, mas são igualmente desprovidos de maior tradição operária, a sua orientação predominante parece ser para a utilização dessas vantagens em termos de uma perspectiva de sucesso individual, que lhes parece proporcionar resultados mais concretos e imediatos do que a pressão coletiva, política e sindical do conjunto da classe. No caso dos trabalhadores da Empresa Automobilística nascidos no Grande São Paulo, estamos em presença de um grupo operário que, tipicamente, está movido mais por um projeto de ascensão social mais do que de simples melhoria de $v i d a$, tal como ocorre mais geralmente entre os migrantes da agricultura.

$\mathrm{O}$ aspecto que parece paradoxal nas tabelas anteriores é a opinião sobre a greve e as atitudes com relação ao sindicato expressadas pelos trabalhadores recentemente chegados a São Paulo (Trad.) Já vimos que a porcentagem de sindicalizados, entre eles, é ligeiramente superior à dos Mod. Vimos também, nas Tabelas 38 e 39, que os Trad., comparativamente, mostram-se mais propensos a valorizar a greve como arma de pressão contra os patrões para fins de obtenção de reajustamentos salariais. Vimos ainda que foi entre esses trabalhadores de migração recente que a organização sindical mais nitidamente se configurou como uma entidade assistencial. As atitudes ante a greve e o sindicato parecem contraditórias. Infelizmente, não podemos oferecer mais do que simples hipóteses. De um lado, é possível que os Trad. valorizem, no sindicato, os serviços que efetivamente utilizam, isto é, os serviços médicos. Por outro lado, não se pode excluir que - na ausência de recursos individuais que os capacitem a ascender na empresa e em decorrência do descontentamento mais acentuado que manifestam quanto aos salários - inclinem-se mais fortemente a aceitar a greve. Mas estamos, neste ponto, no terreno das opiniões, pois não foi possível medir a participação efetiva dos diferentes grupos operários em movimentos grevistas, uma vez que ações dessa natureza não ocorreram na Empresa Automobilística. De todo jeito, fica claro que, pelo menos verbalmente, os trabalhadores de origem agrícola, em confronto com os estratos operários mais urbanizados, não se mostram mais refratários à utilização da greve como arma de pressão sobre os grupos patronais. $\mathrm{Na}$ verdade, é preciso dizer que a companhia investigada não oferece as melhores condições para o estudo do conflito industrial porque a valorização da empresa e a rejeição do sindicato constituem o denominador comum que aproxima os diversos grupos de operários, sindicalizados e não sindicalizados, mais qualificados e menos qualificados, radicados há mais tempo em São Paulo e aqui chegados recentemente. Por tudo isso, a Empresa Automobilística constitui antes lugar privilegiado para o exame das atitudes de operários de um país subdesenvolvido que se inserem no moderno sistema de produção e para o estudo das relações industriais que se estabelecem entre, de um lado, um proletariado de baixo nível de escolaridade e formação técnica, desprovido de meios de pressão sindical e política eficiente e, de outro, empresas estrangeiras poderosas que para aqui trazem toda a experiência adquirida no trato com trabalhadores de seus países de origem. 
OS TRABALHADORES E A POLÍTICA

$\mathrm{N}^{\circ}$

os capítulos precedentes examinamos as atitudes e orientações dos trabalhadores da Empresa Automobilística ante a empresa, o trabalho e o sindicato. Nas páginas que se seguem procuraremos investigar seu comportamento ante a sociedade global e a política nacional. Concretamente, trata-se de expor as orientações políticas de um grupo operário de formação recente e empregado numa moderna unidade de produção, caracterizada pelo trabalho parcelado e em série, formada no impulso desenvolvimentista dos últimos decênios.

Anteriormente, mencionamos as atitudes positivas manifestadas com relação ao processo de desenvolvimento econômico, ou seja, a valorização da industrialização, aspecto que se distingue notavelmente das atitudes críticas adotadas pelo proletariado europeu com relação à sociedade industrial nas fases iniciais da expansão cio capitalismo.

Ainda que se possa registrar uma proporção minoritária relativamente importante de respondentes que avaliaram negativamente as consequências do processo de industrialização, a grande maioria, cerca de dois terços, acredita que o desenvolvimento do país tem beneficiado os trabalhadores. Como se verificará nas tabelas seguintes, os juízos mais favoráveis se encontram entre os operários.

Tabela 45: "O desenvolvimento do país tem beneficiado os trabalhadores?"

\begin{tabular}{|l|c|c|c|c|}
\hline & Operários & Ferramenteiros & Mod. & Trad. \\
Tem & $81 \%$ & $75 \%$ & $62 \%$ & $68 \%$ \\
Não tem & 11 & 17 & 24 & 11 \\
Depende & 8 & 8 & 14 & 21 \\
$\mathrm{n}=$ & $(100 \%)$ & $(100 \%)$ & $(100 \%)$ & $(100 \%)$ \\
Sem resposta & 62 & 24 & 22 & 20 \\
\hline
\end{tabular}

Chamam a atenção, no quadro 40, as porcentagens ligeiramente superiores de respostas negativas entre os Mod. e Trad. em comparação com os operários e ferramenteiros. Entre os primeiros, especialmente, encontramos $24 \%$ de entrevistados que analisaram negativamente as consequências do desenvolvimento econômico para a classe operária. Entre os respondentes que afirmaram que o desenvolvimento foi prejudicial aos trabalhadores, a grande maioria responsabilizou diretamente o processo inflacionário, enquanto uma minoria afirmou que as empresas e o capital estrangeiro e que lucraram efetivamente com a expansão industrial. ${ }^{1}$

Os benefícios do desenvolvimento são avaliados quase que unicamente do prisma de novas oportunidades de emprego, da facilidade de arrumar trabalho, dada a criação de novas indústrias. Porém, somente uma pequena porcentagem de entrevistados referiu-se diretamente à elevação salarial como um dos fatores positivos da industrialização.

Tabela 46: "Por que o desenvolvimento beneficiou os trabalhadores?" (Total de entrevistados)

"Porque há mais empregos e mais indústrias"

"Porque os salários são mais elevados, porque elevou-se o padrão de vida"

"Porque há mais escolas"

Outras respostas

$\mathrm{n}=$

Sem resposta

Obs. Respostas múltiplas. Soma das porcentagens superior a 100\%\%.

É significativo que a quase totalidade dos respondentes tenha justamente acentuado as novas oportunidades de trabalho e não a melhoria do padrão de vida. Indubitavelmente, o grupo estudado experimentou uma elevação dos níveis de consumo, mas, queremos crer, essa elevação não foi proporcional aos novos empregos ofertados, às oportunidades profissionais abertas e às expectativas e esperanças do grupo. Se, por outro lado, a industrialização multiplicou as oportunidades de profissionalização e a oferta de empregos, por outro lado, criou novas aspirações e necessidades de consumo que foram apenas parcialmente atendidas. $\mathrm{Na}$ realidade, o impulso industrial, particularmente acentuado em meados da década dos 50 ate inícios da dos 60, não levou a uma distribuição mais igualitária da renda. Mercê do baixo nível de qualificação profissional e educacional das camadas operárias, da pressão do excedente de mão de obra, que vem

\footnotetext{
${ }^{1}$ Os motivos apontados pelos que responderam que o desenvolvimento não beneficiou os trabalhadores foram os seguintes (em números absolutos): "O custo de vida aumentou": 4 menções; "Há muita política": 2 menções; "Os lucros vão para os EUA": 2 menções; "As empresas é que se beneficiaram": 2 menções; "Gastou-se muito dinheiro com a construção de Brasília": uma menção; "A situação da lavoura piorou”: uma menção.
} 
prejudicando a elevação do preço do fator trabalho, o proletariado brasileiro não esteve em condições de lograr vantagens mais substanciais no curso do impulso industrial no período mencionado. Ao que tudo indica, para amplos setores da força de trabalho brasileiro, a melhoria do padrão de vida resultou mais da obtenção de emprego na indústria do que da elevação dos salários reais que acompanhasse o incremento da produtividade, como soe acontecer nos países industrialmente avançados.

"Agora e mais fácil arranjar emprego. Quanto mais desenvolvimento, mais serviço".

"As estradas oferecem maior facilidade de viagem. As indústrias deram bastante serviço para nós".

"Aumentou o número de empregos, mas o nível de vida não melhora".

"Com as indústrias há mais serviço para os desempregados, mas os lucros e os benefícios do desenvolvimento não têm sido para os empregados".

São essas circunstâncias que, a nosso entender, permitem explicar por que os trabalhadores da Empresa Automobilística veem nas vantagens da industrialização principalmente novas oportunidades de trabalho e, muito secundariamente, elevação do padrão de consumo. Desenvolvimento, em larga medida, e entendido pelo proletariado como sinônimo de maiores oportunidades de trabalho.

Não se percebe aqui o temor que o incremento do maquinismo e da civilização industrial se acompanhe de desemprego, da perda dos ofícios tradicionais, pois se trata de grupos operários que adquiriram sua profissão justamente em consequência da expansão industrial e da mecanização.

A insistência quase unicamente nos novos empregos surgidos com a industrialização pode ser entendida, por outro lado, em relação com o processo de desvalorização da moeda. Os entrevistados, ao mesmo tempo em que insistiam na facilidade de obtenção de novas oportunidades profissionais, ressaltavam os aspectos negativos da inflação. Deste modo, a contenção do processo inflacionário (ao menos no momento em que aplicamos os questionários) era vista como a principal medida a ser adotada para que a situação dos operários melhorasse.
Tabela 47: "O que é preciso fazer no Brasil para que a situação dos operários melhore?”

\begin{tabular}{|c|c|c|c|c|}
\hline Medidas contra a carestia & $\begin{array}{c}\text { Operários } \\
53 \%\end{array}$ & $\begin{array}{c}\text { Ferramenteiros } \\
37 \%\end{array}$ & $\begin{array}{r}\text { Mod. } \\
59 \%\end{array}$ & $\begin{array}{l}\text { Trad. } \\
55 \%\end{array}$ \\
\hline $\begin{array}{l}\text { Reforma agrária e proteção à } \\
\text { agricultura }\end{array}$ & 15 & 4 & - & 30 \\
\hline Um "bom governo", & 10 & 21 & 18 & 15 \\
\hline Escolas e educação para o povo & 6 & 17 & 9 & 5 \\
\hline Reformas de base & 8 & 4 & - & 15 \\
\hline Industrialização & 2 & 4 & - & - \\
\hline Outras respostas & 92 & 20 & 9 & 20 \\
\hline Não sabe & 16 & 12 & 14 & 5 \\
\hline $\mathrm{n}=$ & 62 & 24 & 22 & 20 \\
\hline
\end{tabular}

Obs.: Respostas múltiplas. Soma das porcentagens superior a $100 \%$.

Observa-se entre os Trad. a porcentagem relativamente elevada de menções à reforma agrária e proteção à agricultura (30\%). Na verdade, apenas os trabalhadores chegados recentemente da agricultura fizeram referência ao problema agrário. Os setores mais qualificados (ferramenteiros) praticamente não mencionaram este ponto. A menção à situação do lavrador, por parte dos Trad., parece lógica, uma vez que se trata de operários recentemente chegados do mundo rural. Mas, notemos que a pergunta referia-se especificamente à situação dos operários e não à dos trabalhadores ou do povo em geral. Aparentemente, subsiste ainda uma forte identificação com a condição socioprofissional anterior, ou seja, a de lavrador. Esta impressão é reforçada pela análise de outras tabelas. Assim, como veremos mais adiante, quando se indagou o que o governo deveria fazer para acelerar o desenvolvimento do país, as referências ao problema agrário foram bastante mais acentuadas entre as categorias mais qualificadas e entre os trabalhadores de origem urbana, enquanto os Trad. e Agric. acusaram fracas proporções de respostas nesta direção. Possivelmente, tenhamos aqui a influência da propaganda em favor da reforma agrária, particularmente forte no período em que fizemos as entrevistas, fazendo com que os trabalhadores de maior experiência no meio urbano a citassem quando a pergunta dizia respeito à situação do país, mas a deixassem inteiramente de lado quando a discussão girava em têm ${ }^{\circ}$ da situação específica dos operários. 
Os algarismos anteriores corroboram, novamente, um aspecto de que já tratamos: a importância que os setores mais qualificados e urbanizados atribuem à educação em contraposição aos grupos menos qualificados: 17\% dos ferramenteiros mencionaram escolas e educação para o povo contra apenas $5 \%$ dos Trad.

As respostas à pergunta anterior ganham novas dimensões se confrontadas com a tabela que se segue, possibilitando captar outros ângulos das atitudes e orientação do grupo.

Tabela 48: "O que, na sua opinião, um governo precisaria fazer para que o Brasil progrida?"

\begin{tabular}{|l|c|c|c|c|c|c|}
\hline & Operários & Ferramenteiros & Urb. & Agric. & Mod. & Trad. \\
Ref. agrária, proteção à agricultura & $26 \%$ & $58 \%$ & $45 \%$ & $99 \%$ & $55 \%$ & $35 \%$ \\
Combater a inflação & 16 & 21 & 16 & 19 & 18 & - \\
Estimular a industrialização & 10 & 33 & 22 & 8 & 14 & 35 \\
Moralização da vida pública, & 10 & 12 & 8 & 14 & - & - \\
governantes e políticos honestos & & & & & & \\
Educar o povo; criar escolas & 3 & 17 & 6 & 8 & 5 & 10 \\
profissionais & 11 & 8 & 8 & 14 & 14 & 15 \\
Proteger os trabalhadores & 6 & 11 & 11 & 8 & 14 & 15 \\
Medidas de cunho nacionalista & 28 & 12 & 29 & 17 & 14 & 15 \\
Outras respostas & 10 & 14 & 4 & 14 & 5 & 10 \\
Não sabe responder & 62 & 24 & 49 & 37 & 22 & 20 \\
n-= & $2 \%$ & - & - & $3 \%$ & - & - \\
Sem resposta & & & & \\
\hline
\end{tabular}

Obs.: Respostas múltiplas. Soma das porcentagens superior a 100\%. Porcentagens extraídas excluindo-se os que não responderam.

A julgar por esses resultados, o problema agrário passou a sensibilizar setores relativamente importantes das camadas operárias. São as categorias profissionalmente mais qualificadas as que se mostram mais atentas à questão, possivelmente porque, mais expostas à ação dos meios de comunicação de massa, foram as mais atingidas pela propaganda e agitação efetuada em torno da reforma agrária e pelas chamadas "reformas de base". Amiúde, a proteção à agricultura era relacionada pelos entrevistados aos esforços de barateamento dos gêneros alimentícios e de contenção à inflação. Uma fração minoritária, nesse sentido, mencionou a reforma agrária como um meio de reduzir o êxodo rural e, consequentemente, a concorrência da mão de obra oriunda do setor primário.
Chama a atenção o fato de que a industrialização tenha recebido fraca referência por parte dos operários comuns (mencionada apenas por $10 \%$ dos entrevistados). No entanto, uma proporção bastante maior de ferramenteiros $(33 \%)$ a apontou como uma das medidas a serem adotadas para estimular o desenvolvimento do país. Fração mais modesta de respondentes reclamou por soluções que classificamos como "nacionalistas", tais como: restrição à remessa de lucros das companhias estrangeiras, impulso e proteção à indústria nacional, etc. (6\% dos operários e $11 \%$ dos ferramenteiros).

Em resumo, examinando-se conjuntamente as duas tabelas, vê-se, em primeiro lugar, a inexistência de menção a reivindicações socioprofissionais. Não encontramos nenhuma referencia a qualquer exigência que pudesse ser chamada de especificamente operária, como, por exemplo, questões relacionadas à legislação trabalhista ou aos sindicatos, etc., para não falarmos de reivindicações de cunho socializante. É certo que alguns entrevistados referiram-se a medidas de proteção ao trabalhador, mas fizeram-no do ângulo da assistência social. Apenas os ferramenteiros, numa proporção mais elevada, citaram reivindicações de cunho educacional e, em especial, criação de escolas técnicas.

Dois itens, a que não fizemos referência nos comentários anteriores, merecem ser destacados: a "moralização da vida pública" e "bom governo". Embora nas tabelas em foco ambos não tenham sido mencionados por uma porcentagem elevada de respondentes, dão-nos valiosos indícios para a inteligência de determinados elementos que fundamentam as orientações políticas e sociais dos trabalhadores. Pelo momento, apenas nos limitaremos a algumas observações preliminares, deixando para o final do capítulo uma discussão mais ampla da questão. Sob esses itens se esconde uma percepção tradicional das relações entre os grupos e instituições sociais, ou, mais exatamente, da teia de determinações que configura concretamente o modo de vida dos trabalhadores. Os fatores que são considerados responsáveis pela situação socioeconômica dos operários não são localizados pelos entrevistados nos mecanismos da produção e do mercado, ou sela, na esfera do sistema econômico, mais no universo da política, das instituições $e$ dos poderes públicos. Trata-se de uma percepção extremamente "pessoalizada", pré-industrial, dos mecanismos da vida social. O governo e os políticos são encarados como os principais responsáveis pelos aspectos positivos ou negativos (principalmente estes últimos) da "situação" dos trabalhadores. A percepção das medidas e ações dos ocupantes dos altos 
cargos e funções públicas está impregnada de elementos éticos e morais. O "progresso" do país, a melhoria da sorte dos trabalhadores, dependeriam basicamente de "bons governantes", de "políticos honestos".

"É preciso uma reforma geral do governo. O governo precisa se libertar da ação dos maus políticos".

"É preciso acabar com muitas pessoas do governo que ganham sem fazer nada".

"Os políticos não ligam para os operários".

\section{AUTORITARISMO E POPULISMO}

A "culpa" pelo baixo nível de consumo dos trabalhadores não é atribuída aos patrões e empregadores, mas ao governo e aos políticos. ${ }^{2}$ Estes últimos é que são considerados como "exploradores do povo". Importa ressaltar que respostas como as transcritas acima, incidindo sobre medidas e decisões dependentes de um "bom governo" e de "políticos honestos", revelam uma captação da realidade social e dos problemas políticos não propriamente de uma perspectiva operária ou "classista", mas da de povo, situado face a um poder estatal que, ao mesmo tempo, aparece como uma entidade poderosa e desvinculada das camadas ou grupos sociais e

${ }^{2}$ Poder-se-ia relacionar tais atitudes com determinados aspectos da formação da sociedade brasileira, com o próprio processo de constituição do Estado nacional, com os elementos patrimonialistas (no sentido de Weber) que permearam as relações entre a esfera do poder privado e a do poder palio:), e que dificultam a apreensão do político e do econômico como setores da atividade humana diferenciados (embora relacionados), $\mathrm{O}$ processo de racionalização e modernização do Estado nacional - em particular após 1930 - correlatamente ao avanço da industrialização e da urbanização da sociedade brasileira, reduziram o alcance dos elementos patrimonialistas da sociedade brasileira mas nela persistem ainda, com certa vitalidade, numerosos traços de cunho tradicional e pré-industrial, lastreando as orientações valorativas dos agentes e instituições sociais. Uma forma particular de patrimonialismo brasileiro mostrou notável vitalidade: o coronelismo. Segundo V. N. Leal, ele resulta da "superposição de formas desenvolvidas do regime representativo a uma estrutura econômica e social inadequada. Não é, pois, mera sobrevivência do poder privado, cuja hipertrofia constituiu fenômeno típico de nossa história colonial. É antes uma forma peculiar de manifestação do poder privado, ou seja, uma adaptação em virtude da qual os resíduos de nosso antigo e exorbitante poder privado tem conseguido coexistir com um regime político de extensa base representativa". Vitor Nunes LEAL, Coronelismo, Enxada e Voto, Rio, Revista Forense, 1948. Para a análise da evolução do Estado brasileiro, de sua racionalização e das funções que assumiu na vida econômica e social do país, cf. Octávio IANNI, Estado e Capitalismo, Rio, Civilização Brasileira, 1965. identificada com o ocupante do Poder. Nas duas tabelas que vimos de comentar, essas orientações não vêm inteiramente à tona, mas serão facilmente apreendidas no quadro que transcrevemos a seguir:

Tabela 49: "Que tipo de governo poderia apressar o desenvolvimento do país e elevar o nível de vida do povo?"

\begin{tabular}{|l|c|c|c|c|}
\hline & Operários & Ferramenteiros & Mod. & Trad. \\
Ditadura & $35 \%$ & $4 \%$ & $26 \%$ & $40 \%$ \\
Democracia & 18 & 39 & 26 & 10 \\
$\mathrm{n}=$ & 62 & 24 & 22 & 20 \\
\hline
\end{tabular}

Nesta tabela apresentamos, para não fatigar o leitor, apenas as duas respostas que mereceram as porcentagens mais elevadas de preferência. ${ }^{3}$

Mais de um terço dos entrevistados optou clara e categoricamente por "uma ditadura". ${ }^{4}$ Nota-se, por outro lado, que os ferramenteiros que ofereceram respostas semelhantes constituem parcela bastante minoritária: 4\%. A proporção mais elevada de respostas em favor de um governo ditatorial encontra-se entre os Trad. (40\%). Uma tendência configura-se nitidamente: os trabalhadores de nivel profissional e educacional mais aprimorado, com salários mais elevados, inclinam-se por formas

\footnotetext{
${ }^{3}$ Como seria de se esperar, dado o baixo nível cultural dos entrevistados e a dificuldade de conceituação e expressão, as respostas nem sempre foram muito precisas, havendo identificação do tipo de governo com a pessoa do governante. Poder-se-ia objetar que nossa indagação de certo modo cerceia e restringe a escala de variação das respostas ao utilizar a palavra "governo" e não "regime", "sistema político", etc. De fato, tínhamos pensado inicialmente em utilizar a segunda fórmula. No entanto, verificamos no pré-teste do questionário, que, amiúde, os trabalhadores não entendiam seu significado. Assim sendo, optamos pela palavra "governo", mais familiar e de significado suficientemente elástico e vago no uso comum para englobar o sentido do termo "regime", etc. Na maior parte das vezes, foi impossível estabelecer itens mais precisos para a tabulação. Evidentemente, este inconveniente poderia ser superado caso o respondente tivesse que optar por alternativas oferecidas de antemão. Contudo, julgamos que, assim procedendo, poderíamos influenciar as respostas e que melhor seria deixar a pergunta inteiramente aberta, devendo o entrevistador anotar ipsis litteris a resposta do entrevistado.

${ }^{4}$ A relação completa dos itens (para o total dos entrevistados), segundo a porcentagem das respostas que receberam é a seguinte: "Governo atual, mas melhorado": 11\%; "Governo honesto, bom, que defenda os operários": 6\% "Governo como o dos Estados Unidos": 3\%; "Governo como o do J. K":. 2\% "Governo como o do Jânio": 2\%; "Ditadura ou governo do povo": $3 \%$; "Ditadura ou democracia socialista": $2 \%$; "Governo como o do Adhemar": $1 \%$; "Governo que fizesse as reformas de base": $1 \%$; Outras respostas: $6 \%$; Não souberam responder: $9 \%$. Vale observar que $11 \%$ dos operários contra $4 \%$ dos ferramenteiros não souberam responder.
} 
democráticas de governo, enquanto as camadas inferiores do proletariado tendem a preferir regimes autoritários.

À primeira vista, se considerarmos "ditadura" e "democracia" como formas opostas de governo, deveríamos concluir por opções políticas fortemente contrastantes entre os que deram uma ou outra resposta. Particularmente, cumpriria, dessa perspectiva, destacar uma orientação radicalmente diversa entre operários e ferramenteiros. Mas seria perigoso levar muito longe tal dicotomia. Quando se examinam as explicitações das respostas pode-se perceber um substratum comum que contribui para que as diferentes orientações não fiquem tão distanciadas como pareceriam à primeira vista, se se atém unicamente às respostas formais dos trabalhadores. No fundo, em praticamente todas as respostas, mesmo entre as que diziam, por exemplo, "governo atual melhorado" ou "governo honesto, que defenda os operários", foi possível perceber um profundo descontentamento com relação ao status quo político. Como "povo" esses trabalhadores se sentem "explorados" e desprotegidos. Porem, como foi assinalado, os agentes e fatores responsáveis não são localizados na esfera econômica, mas na política, na forma de governo, nos elementos da administração, na burla ou na violação das leis. Os empregadores, os patrões, os proprietários dos meios de produção não são, na grande maioria dos casos, apontados como os responsáveis pelos aspectos negativos da condição operária. Se o são, a culpa maior cabe ao governo, que não faz cumprir a lei, que não protege os trabalhadores e o povo contra os "maus patrões", os "comerciantes inescrupulosos". Estes últimos são particularmente citados, fato indicativo de uma crítica que se baseia principalmente na posição do operário como "consumidor" e não como "produtor".

Os diferentes tipos de respostas, optando por esta ou aquela forma de governo, por este ou aquele político, quase invariavelmente punham ênfase em atributos tais como: honestidade, energia, restrição aos maus políticos, sobretudo vereadores e deputados.

"Uma democracia, desde que existam homens com capacidade e honestidade para dirigir o país".

"O tipo do governo atual, mas sem a interferência de políticos mal intencionados".

"Um governo democrático, desde que estivesse nas mãos de pessoas honestas e de bom-senso, como foi nos Estados Unidos".
Para os que optaram por formas autoritárias, a ditadura é encarada como sendo precisamente a melhor solução de se obter um governo honesto, decente, capaz de defender os trabalhadores contra os maus políticos e os comerciantes "exploradores".

"Uma ditadura. É preciso acabar com a exploração que existe no país. Existem muitos deputados e comerciantes que são ladrões e só um governo de mão forte poderia acabar com isso".

"Acho que tem muito político e isso é prejudicial. Na ditadura só um manda, e isso é bom. O que interessa é que a direção seja honesta".

"Seria interessante que tivéssemos um regime forte, ditatorial, para que não subisse o custo de vida".

"Uma ditadura honesta, onde não houvesse deputados, senadores, vereadores. Um governo que não tivesse uma quadrilha ao seu redor, nem compromissos com quem fosse".

Seria cansativo multiplicar essas citações. O elemento constante, como se pode ver, é a crítica aos corpos legislativos, aos políticos e comerciantes. $\mathrm{O}$ importante, sempre, é um governo eficiente e honesto, que não esteja tolhido pela ação dos "políticos". Observemos, demais, que também os entrevistados que "pessoalizaram" o tipo de governo em suas respostas, citando líderes populistas como Jânio Quadros, Adhemar de Barros ou Getúlio Vargas, insistiam no fato de que esses políticos deveriam governar com mão forte, de modo discricionário, livre das peias dos corpos legislativos.

"Ditadura, como a do Getúlio, para acabar com os "tubarões" e com a exploração".

Adhemar, sem câmara, um só homem mandando. O bom seria uma "panela" mandando, como o Salazar. Deve ser pessoa honesta, como Salazar. Fidel é malvado, manda para a forca".

"Governo sem política. Uma ditadura "legal". O Getúlio, por exemplo".

A lembrança do governo Vargas parece estimular em grande parte as respostas favoráveis a um regime autoritário. Com efeito, $6 \%$ dos operários explicitaram inequivocamente: uma ditadura, "como a do Getúlio".

Analisando as respostas, fica clara a avaliação negativa e a rejeição, senão do regime político vigente no momento das entrevistas, pelo menos de muitas de suas facetas. Examinando-se mais de perto o conteúdo das respostas, percebe-se que a proporção de trabalhadores favoráveis a um 
regime autoritário ou abertamente ditatorial é muito maior do que indicaria a simples classificação porcentual dos que se manifestaram taxativamente por um governo ditatorial. Com efeito, muitos dos que responderam elidindo a dicotomia "democracia-ditadura", isto é, pessoalizando o tipo de governo que poderia melhorar a situação dos operários, acrescentavam alguma ressalva indicando a preferência por um governo forte: "Governo atual com uma turma enérgica", na expressão de um dos entrevistados. Parece, pois, fora de dúvida que a maioria dos entrevistados é favorável a formas autoritárias de governo e que essa preferência se acentua nos setores menos qualificados e com menor experiência de vida urbana.

Estes resultados fazem pensar imediatamente nas considerações de Lipset sobre o autoritarismo das classes operárias. De acordo com o sociólogo norte-americano, as inclinações para movimentos políticos autoritários estariam relacionadas ao modo de viver dos indivíduos que compõem os estratos inferiores da sociedade: "Muitos (...) estudos sugerem que a maneira de viver da classe baixa produz indivíduos com enfoques rígidos e intolerantes no que diz respeito à política". ${ }^{5}$ Três fatores agiriam no sentido de levar as camadas inferiores a apoiar regimes autoritários: baixo nível de renda, ocupações específicas de status baixo e instrução limitada. Segundo Lipset, as camadas operárias são por outro lado, "mais liberais ou esquerdistas nas questões econômicas; favorecem as medidas estatais por um maior bem-estar, por maiores salários, impostos proporcionais à renda, apoio aos sindicatos, etc. Porém, quando o liberalismo é definido em termos não econômicos, como apoio às liberdades civis, internacionalismo, ${ }^{6}$ etc., a correlação se inverte. Os mais acomodados são mais liberais, os mais pobres são os mais intolerantes" (p.82). Lipset localiza as raízes do autoritarismo das camadas operárias (o autor refere-se algumas vezes a "camadas pobres") no tipo de educação recebida pelas crianças nos lares operários. Em contraposição ao que ocorreria nas famílias de renda mais elevada, a educação do jovem operário se caracterizaria pelo autoritarismo, pela maior frequência de castigos corporais, etc. Apoiado nos trabalhos de Hoggart e em outras pesquisas, Lipset conclui que, na educação ministrada nos lares operários, a "ênfase no

\footnotetext{
${ }^{5}$ Seymour Martin LIPSET, "Autoritarismo de la Clase Obrera”, in: El Hombre Político, Buenos Aires, Eudeba, 1963, p. 78.

${ }^{6}$ Segundo Lipset, os grupos trabalhadores, depois de 1914, principalmente, deixaram
} paulatinamente da apoiar posições internacionalistas. imediato e no perceptível e uma preocupação pelo pessoal e pelo concreto formam parte inseparável da perspectiva restrita e da incapacidade para perceber as posições e consequências complexas das ações, o que resulta, frequentemente, numa disposição geral para apoiar os movimentos políticos e religiosos extremistas, e um nível geralmente baixo de liberalismo nas questões não econômicas" (p. 99).

As investigações da Lipset têm o mérito de chamar a atenção para alguns componentes do comportamento e das orientações políticas operárias. Entretanto, julgamos que algumas restrições devem ser feitas, principalmente tendo em vista uma interpretação mais profunda das orientações políticas e ideológicas observadas entre os trabalhadores da Empresa Automobilística. Não pretendemos nos alongar na discussão do próprio conceito de democracia, sujeito a diversas definições e entendido de modo diferente pelos vários setores sociais, como já observaram S. M. Miller e F. Riessman em sua crítica a Lipset. ${ }^{7}$ Constantemente, neste último há a identificação entre camadas operárias e camadas inferiores, o que não parece correto, de vez que as segundas, mais amplas e abrangendo outros segmentos socioeconômicos e socioprofissionais, não podem ser reduzidas às primeiras. Por outro lado, o autor identifica a tolerância política individual com posições democráticas, passando do nível individual para o social, ou seja, através da psicologia dos indivíduos que constituem a classe ou camada social, procura deduzir o comportamento grupal, o que conduz a esquecer a dinâmica própria do grupo, como algo mais do que a soma dos indivíduos que o compõem. ${ }^{8}$ Porém, o que nos parece ser a lacuna mais séria do interessante trabalho de Lipset, é a inexistência de qualquer tentativa de estabelecimento das conexões de sentido entre o que ele denomina de autoritarismo no campo das atitudes políticas e de liberalismo na esfera do econômico. Parece evidente que ambas orientações estão relacionadas. O apoio a formas autoritárias de organização política serve

${ }^{7}$ Cf. S. MILLER e Frank RIESSMAN, "Working-class Authoritarianism: a Critique of Lipset", The British Journal of Sociology, setembro de 1961. Veja-se também, no mesmo número, a resposta de Lipset: "Working Class Authoritarianism: A Reply to Miller and Riessman".

8 "A aceitação das normas democráticas exige um alto nível de refinamento e de segurança do Eu. Quanto menos educado e estável seja o indivíduo tanto mais possível será que tenha um ponto de vista simplista em política, que não chegue a compreender o conceito em que se apoia a tolerância para os que não concordam com ele, e que ache dificuldade em compreender e tolerar uma imagem gradual da mudança política". S. M. LIPSET, "Autoritarismo de Ia Clase Obrera", p. 95. 
como meio para a consecução de objetivos democráticos (ou liberais, segundo a terminologia de Lipset) no campo da atividade econômica. Os objetivos democráticos não devem ser considerados como fins em si mesmos, e não podem ser separados de um contexto mais amplo de variáveis sociais, políticas e econômicas no qual se insere o comportamento do trabalhador. As orientações políticas democráticas das associações operárias com frequência ganham preeminência e passam ao primeiro plano quando os regimes autoritários ou totalitários, sustentados pelas camadas superiores, parecem constituir-se como barreiras para a consecução dos alvos "democráticos" das camadas operárias no plano econômico. Por outro lado, em Lipset, as condutas "autoritárias" das camadas superiores não são nem mencionadas, embora se possa pensar que algumas formas de comportamento autoritário das camadas operárias constituem reações ou tentativas de respostas a outras instituições da estrutura autoritária de dominação cujo controle encontra-se nas mãos de outros grupos sociais, instituições sobre as quais as camadas operárias não possuem (ou possuem em escala muito reduzida) capacidade de influenciar.

Julgamos que cumpriria examinar o sentido das orientações "autoritárias" das camadas operárias, inserindo-as num contexto mais concreto de análise. A partir de critérios formais de definição de autoritarismo e liberalismo - em geral segundo o modelo dos países altamente desenvolvidos $^{9}$ - é possível equacionar-se o comportamento das camadas operárias em termos de "mais" ou "menos" autoritarismo, porém perde-se o significado contido em tais orientações. Assim, por exemplo, classificado o peronismo como regime autoritário e verificado o apoio que lhe foi prestado pelas camadas operárias argentinas, pode-se concluir pelo autoritarismo dos trabalhadores e pelas tendências democráticas ou liberais das camadas e grupos sociais que se lhe opuseram. Mas perde-se inteiramente o significado e os objetivos contidos nas formas de conduta política e o sentido da atuação dos agentes sociais, o porquê de tais orientações.

Essas observações sumárias parecem importantes para melhor apreender o sentido das atitudes políticas dos trabalhadores da Empresa Automobilística e, em larga medida, do proletariado brasileiro. É evidente

\footnotetext{
${ }^{9}$ Segundo S. M. MILLER e F. RIESSMAN, os critérios que Lipset utiliza para avaliar o "comportamento operário são particularmente agradáveis à moderna classe média liberal mas não constituem a única maneira de se conceituar a democracia”. Op. cit., pp. 263-264.
}

que, quando os entrevistados se pronunciam favoravelmente a um governo forte, não estão desejando um regime que comprima a renda das camadas assalariadas, que elimine os benefícios sociais contidos na legislação trabalhista, etc. Em poucas palavras, não aspiram a uma ditadura que se dirija contra os operários. Ao contrário, o sentido das respostas é muito claro: uma ditadura para apressar o desenvolvimento e elevar o nível de vida dos trabalhadores.

Os dados indicam, igualmente, na medida em que o grupo estudado pode ser considerado como representativo de uma parcela do proletariado brasileiro, que os valores do regime democrático de representação popular, segundo modelo que conhecemos no Ocidente, têm medíocre significado para as camadas populares no Brasil. As formas democráticas de poder não lhes parecem propiciar as condições mais favoráveis para o atingimento de suas reivindicações e aspirações. A inadequação entre a estrutura social e econômica do país e seu arcabouço institucional, jurídico e político, fizeram da democracia representativa brasileira um pobre arremedo do sistema democrático ocidental. Mais do que permitir o acesso institucionalizado e legitimado das camadas populares ao Poder e uma distribuição mais igualitária da renda, os regimes representativos permitiram apenas a participação na vida política nacional de restritos setores populacionais superiores. "A organização legal existente - ressalta F. Fernandes - confere igualdade política aos cidadãos e organiza o regime republicano em bases democráticas. As classes sociais que compõem a sociedade não possuem possibilidades análogas de participar efetivamente dessas garantias jurídicas-políticas. Algumas classes monopolizam a fruição de tais garantias, convertendo a democracia numa ficção e numa cômoda armadilha, pois a concentração da renda corresponde à concentração do poder, o que coloca os socialmente "fracos" à mercê dos socialmente "fortes". (...) Todavia, ao inverso do que sucedia sob a ordem social patrimonialista, as classes sociais prejudicadas não só tomam consciência do sacrifício de garantias sociais básicas e das consequências nefastas que daí advêm. Opõem-se como podem a tal situação, ouvindo ou apoiando os demagogos, aderindo a formas compensatórias ou eficientes de inconformismo, predispondo-se à radicalização política e à ação pela violência, etc. No entanto, como se identificam com os componentes sociais consagrados pela ordem social vigente, sua oposição não se ergue "contra o regime", claramente, mas "contra as injustiças de que são vítimas", 
perdendo-se esterilmente sem assegurar a estruturação de movimentos sociais de protesto e de luta suscetíveis de provocar o almejado saneamento do regime". ${ }^{10}$ Neste contexto, que a citação acima sintetiza, as camadas populares brasileiras não tiveram experiências positivas com o sistema representativo, de modo a estimular uma adesão aos valores democráticos proclamados pela civilização ocidental. ${ }^{11}$

Regimes autoritários parecem aos trabalhadores e às camadas populares uma forma de defesa contra forças e grupos socioeconômicos contra os quais se sentem inermes sob uma "democracia representativa". Esta orientação é reforçada pelo fato de que um conjunto de leis sociais, extremamente valorizado pelos operários, foi promulgado precisamente por um governo autoritário, sendo a legislação trabalhista, por exemplo, associada ao período de Vargas. A ditadura - ou outras formas de governo autoritário - parece-lhes favorecer aos pobres e a democracia aos ricos, aos políticos e comerciantes desonestos. Para uma classe operária que possui meios limitados de intervenção na política nacional e de pressão sobre os grupos empresariais, o autoritarismo no plano político surge como uma via para a democratização no plano econômico e social.

Não se deve inferir do que foi dito que a maioria dos operários entrevistados, ao pronunciar-se favoravelmente a uma ditadura, entenda por essa palavra algo equivalente à "ditadura do proletariado", na acepção leninista, ou a qualquer outra forma de governo socialista ou de

\footnotetext{
${ }^{10}$ Florestan FERNANDES, "Crescimento Econômico e Instabilidade Política no Brasil”, Comunicação aos VI Colóquios Luso-Brasileiros, Columbia University-Harvard University, Nova York, 1966, (dat.).

11 "Para a maioria dos países da América Latina, e em particular para as camadas recémmobilizadas, os símbolos da democracia perderam - ou melhor, nunca tiveram - uma significação positiva. Pelo contrário: devido à tradição política dessas nações, tendem antes a possuir um valor negativo. Não houve ditadura, autocracia absoluta e arbitrária que não haja empregado desmedidamente os símbolos e a terminologia da democracia. Os ditadores e generais sempre se consideraram "presidentes constitucionais" popularmente eleitos, todos tiveram parlamentos e, sobretudo, abundaram as "constituições" extremamente generosas quanto aos direitos políticos e, recentemente, também no que se refere aos direitos sociais. Porém, em nenhum lugar houve um abismo mais profundo entre a realidade e a lei. Para os grupos emergentes das zonas atrasadas, inclusive as democracias limitadas que funcionaram com certa regularidade aparecem como instrumentos de dominação em benefício de minorias". Gino GERMANI, "De la Sociedad Tradicional a la Participación Total en América Latina", op. cit., pp. 160-161.
}

"democracia popular", ${ }^{12}$ semelhante aos regimes políticos que vigoram nos países de economia planificada. Tampouco pensam os respondentes que o regime autoritário deva ser presidido por "representantes" do proletariado. Os fundamentos sociais de tal regime não são explicitados, mas as diversas respostas deixam claro que a ditadura estaria sob o braço forte de um homem das camadas "ilustradas", originário dos grupos superiores, capaz, por isso mesmo, de enfrentar os outros ricos e coibir a ação dos "exploradores do povo". O importante e que a ditadura seja "honesta" e "eficiente", pois, consequentemente, seria favorável aos trabalhadores, aos pobres, aos oprimidos.

A preferência por formas autoritárias ou totalitárias de governo, por um lado, está relacionada, em primeiro lugar, com um sentimento de impotência, de incapacidade de interferir, como grupo ou camada social, na vida política nacional. Neste sentido, significa abdicação a um papel autônomo, de classe. A opção por formas democráticas de governo - nos quadros de uma economia de tipo capitalista - exigiria, além da crença na eficácia dos mecanismos políticos da democracia, um proletariado mais confiante em suas próprias forças, capaz de pressionar fortemente a camada empresarial e os poderes públicos, a fim de lograr a consecução de suas reivindicações profissionais e econômicas; por outro lado, as inclinações "autoritárias" do proletariado, do modo como são formuladas pelo grupo pesquisado, indicam que os trabalhadores não percebem a sociedade como dividida em classes sociais antagônicas e não estabelecem relação entre a dominação econômica e a dominação política, não sendo o Estado entendido, para parafrasear Marx, como "o comitê executivo da classe burguesa".

Dissemos que os entrevistados que expressaram suas preferências por uma ditadura (ou por um governo forte) não pensavam, Obviamente, que ela poderia ser exercida contra os trabalhadores, em prejuízo de suas exigências econômicas e sociais. É sugestivo, deste prisma, que os ferramenteiros - que mostraram taxas mais elevadas de sindicalização, maiores índices de participação social e política, bem como uma relação mais positiva com o trabalho e melhores condições para uma pressão grupal

12 Entre os ferramenteiros, encontramos uma porcentagem relativamente elevada de informantes que ofereceram respostas "radicais" ou "esquerdizantes". Assim, por exemplo, $8 \%$ indicaram como a melhor forma de governo "um governo nacionalista" e $12 \%$ "uma ditadura ou governo do povo". Entre os operários, $3 \%$ optaram por uma "ditadura socialista". 
- rejeitem maciçamente uma solução política autoritária no interior da presente estrutura econômica. Não se deve concluir daí que, no conjunto, sejam os ferramenteiros mais "radicais" ou "esquerdizantes" em suas orientações e preferências políticas e ideológicas. Pelo contrário. Ainda que seja entre eles que se encontrem os entrevistados "mais esquerdistas", como grupo, esta categoria profissional tende a posições políticas mais moderadas, tanto à esquerda como à direita. Cumpre não esquecer que uma maior agressividade reivindicativa pode estar associada a uma consciência profissional corporativista e a melhores possibilidades de conduzir uma luta reivindicativa ante a empresa, diferenciando-se bastante, neste aspecto, dos trabalhadores semiqualificados ou braçais, sujeitos mais fortemente à ameaça do desemprego e à concorrência do "exercito industrial de reserva". Talvez por tais razões é que encontramos, entre esses últimos setores, índices de fraca participação política e social acompanhados de opções políticas mais radicais expressadas pela preferência aos candidatos populistas de coloração mais nacionalista e esquerdista.

\section{COMPORTAMENTO ELEITORAL E ATITUDES POLÍTICAS}

A observação anterior leva-nos a examinar o comportamento eleitoral do grupo. A análise das tabelas 45 e 46 ajudarão a esclarecer as variações encontradas entre os entrevistados, segundo a qualificação profissional e a experiência de vida no meio urbano.

Tabela 50: "Nas últimas eleições, para Governador do Estado de São Paulo (1962), o Sr. votou em..."

\begin{tabular}{|l|c|c|c|c|}
\hline & Operários & Ferramenteiros & Mod. & Trad. \\
Jânio Quadros & $28 \%$ & $55 \%$ & $49 \%$ & $15 \%$ \\
Adhemar de Barros & 29 & 21 & 18 & 20 \\
José Bonifácio & 7 & 8 & 5 & 15 \\
Cid Franco & - & 4 & 5 & - \\
Em branco & 11 & 4 & 18 & 5 \\
Não votou & 25 & 8 & 5 & 45 \\
& $(100 \%)$ & $(100 \%)$ & $(100 \%)$ & $(100 \%)$ \\
n= & 62 & 24 & 92 & 20 \\
Sem resposta & $2 \%$ & & & \\
\hline
\end{tabular}

A preferência por Jânio Quadros é claramente mais pronunciada entre ferramenteiros e Mod., o que equivale a dizer, entre os entrevistados de nível salarial mais elevado, melhor qualificação profissional e mais tempo de vida em São Paulo. Observa-se, por outro lado, a inexpressiva penetração de José Bonifácio (candidato que pareceu associado às classes superiores e médias tradicionais) e de Cid Franco (candidato do Partido Socialista Brasileiro). Igualmente significativa, entre os operários e Trad., é a alta proporção de indivíduos que se abstiveram de votar. É difícil avaliar com rigor até que ponto esta elevada abstenção se deve a dificuldades na transferência dos respectivos títulos de eleitor para São Paulo, ou simplesmente a um desinteresse pela campanha eleitoral, cujos resultados possivelmente sejam considerados de influência nula para a vida particular desses migrantes.

Cumpre notar que 15\% dos Trad. e 13\% dos operários comuns não tinham título de eleitor. Mas dado que as dificuldades para a regulamentação da situação eleitoral não são demasiadamente acentuadas, julgamos que, em muitos casos, trata-se de uma atitude "pré-política" ou de uma descrença ou indiferença generalizada ante os resultados das urnas, hipótese que ganha consistência se lembrarmos os fracos índices de leitura de jornais, o baixo nível educacional e o repúdio que as camadas inferiores do proletariado manifestaram pelas formas democráticas de governo segundo o modelo dos países desenvolvidos do Ocidente. Em compensação, entre os Mod. e ferramenteiros não encontramos um só trabalhador que não fosse eleitor.

\begin{tabular}{|l|c|c|c|c|}
\multicolumn{5}{c|}{ Tabela 51: “O Sr. é eleitor?" } \\
\hline \multirow{3}{*}{ Sim } & Operários & Ferramenteiros & Mod. & Trad. \\
Não & $87 \%$ & $100 \%$ & $100 \%$ & $85 \%$ \\
& 13 & & & 15 \\
& $(100 \%)$ & $(100 \%)$ & $(100 \%)$ & $(100 \%)$ \\
& 62 & 24 & 22 & 20 \\
\hline
\end{tabular}

Em vários pontos nossas conclusões coincidem com as das pesquisas de F. Weffort sobre o populismo em São Paulo. Comparando os eleitores de Adhemar de Barros e de Jânio Quadros este autor observou maior penetração janista "nos setores mais urbanizados da população, em particular nos núcleos de maior concentração operária". ${ }^{13}$

${ }^{13}$ Cf. Francisco C. WEFFORT, "Raízes Sociais do Populismo em São Paulo", Revista Civilização Brasileira, Rio, maio de 1965. Cf., também, do mesmo autor: "Estado y Masas en el Brasil", Revista Latino-americana de Sociologia, Buenos Aires, março de 1965, e Classes Populares e Política (Contribuição ao Estudo do Populismo), São Paulo, Faculdade de Filosofia, Ciências e Letras (USP), 1968, (mim.) 
Segundo F. Weffort, Jânio Quadros tenderia a "expressar politicamente os setores assalariados - operários e classe media assalariada - mais integrados no desenvolvimento capitalista, diversamente de Adhemar de Barros, que daria expressão a camadas marginais a este processo, em particular pequenos proprietários e setores assalariados de tipo "lumpem". ${ }^{14}$ No nosso caso, encontramos apenas $15 \%$ de eleitores "janistas" entre os trabalhadores chegados recentemente de regiões préindustriais em comparação com os $49 \%$ registrados entre os entrevistados de origem urbana.

O mesmo autor encontrou em ambos os eleitores, de Jânio Quadros e Adhemar de Barros, um "profundo desencanto social". Este mesmo "desencanto" com relação ao status quo nós observamos entre o grupo pesquisado, embora houvesse, concomitantemente, uma valorização e uma apreciação bastante positiva do emprego na Empresa Automobilística.

Esses fatos levam-nos a pôr em dúvida toda sorte de hipóteses que buscam explicar o baixo índice de participação em atividades associativas, profissionais e políticas dos trabalhadores brasileiros com base na suposta satisfação pelas condições de trabalho e de vida no meio fabril e urbano, em contraposição às vigorantes no meio rural e tradicional. Na realidade, todos os dados de pesquisas empíricas efetuadas apontam a insatisfação dos setores populacionais emigrados para os grandes centros urbanos. Os fundamentos dessa insatisfação tentamos apontar nos capítulos precedentes, ao mesmo tempo em que acusávamos a ambiguidade que impregnava as orientações dessas populações, ao mesmo tempo vencedoras e vencidas com referência ao projeto original de melhoria de vida e de ascensão social.

A pesquisa de F. Weffort corrobora também em outros aspectos as tendências observadas entre os trabalhadores da Empresa Automobilística, permitindo-nos inseri-Ias num contexto mais amplo. O descontentamento e a apreciação extremamente crítica da ordem social notada entre as massas janistas e ademaristas, observa o autor, traduzem-se ora por um "moralismo popular", ora por um desejo de proteção, de confiança nos poderes superiores do líder. O primeiro aspecto é mais acentuado entre os janistas e o segundo entre os ademaristas. "O moralismo das massas janistas toma o conteúdo muito popular de limitação dos privilégios que se

\footnotetext{
${ }^{14}$ Francisco C. WEFFORT, "Raízes Sociais do Populismo em S. Paulo", p. 51.
}

associam à corrupção", ${ }^{15}$ observação que coincide com os dados de nossas investigações, nas quais as aspirações de "justiça", "honestidade" e "proteção" transparecem nitidamente nas entrevistas efetuadas.

O populismo, como já se observou, poderia ser definido como uma forma de participação política súbita de massas recém-mobilizadas e recémsaídas dos modelos tradicionais de dominação. Essa definição, no entanto, é ainda insuficiente, pois não capta as formas peculiares que assume este avanço da "democratização fundamental" para usar o conceito de Mannheim. O importante, para a caracterização do populismo - quaisquer que sejam as variantes, menos ou mais radicais - é que a entrada das massas no processo político, ${ }^{16}$ escapando dos tipos de controle preexistentes, entre os quais o coronelismo, não se faz através de canais "classistas", como ocorreu na Europa Ocidental. É neste ponto, precisamente, que encontramos o traço essencial que distingue o populismo de outros movimentos sociopolíticos de massas dos países de antiga industrialização. No continente europeu, havia a presença de massas já participantes de uma economia monetária relativamente desenvolvida. As camadas inferiores da população, integradas economicamente pela expansão do sistema industrial, obtiveram paulatina, e mais lentamente do que no Brasil, sua integração política, através da legitimação de direitos sociais e políticos, e das instituições que se ofereciam como representantes destes setores (direitos de voto, legalização dos sindicatos e partidos políticos operários, etc.). No caso brasileiro, trata-se de populações mediocremente integradas numa economia monetária (enquanto consumidores) que passam rapidamente a ter condições formais de participação política, antes de encontrarem vias efetivas de intervenção autônoma e organizada (partidos e sindicatos) no sistema de poder de uma sociedade industrial e relativamente massificada. ${ }^{17}$

\footnotetext{
${ }^{15}$ Francisco C. WEFFORT, "Raízes Sociais do Populismo em São Paulo", p. 59.

${ }^{16} \mathrm{O}$ crescimento do corpo eleitoral brasileiro, aliado ao crescimento das grandes cidades, em grande parte responde pela quebra dos tipos costumeiros de manipulação e controle do eleitorado. Assim, em 1933, o corpo eleitoral brasileiro era de aproximadamente $1.400 \mathrm{mil}$ eleitores; em 1934, atingiu 2.700 mil; em 1945, 7.300 mil; em 1950, 11.400 mil; em 1955, 15.240 mil; em 1960, 15.500 mil; em 1966, 20 milhões de eleitores.

17 “... A formação de um movimento operário exige uma participação intensa por parte das massas e uma lenta acumulação de experiência organizatória. Este processo dificilmente pode dar-se quando ocorre um repentino incremento no volume da classe operária urbana. Em um país subdesenvolvido, os reduzidos grupos da classe operária, que possuem alguma experiência prolongada no que diz respeito à participação e negociação, geralmente logo se
} 
$\mathrm{Na}$ Europa, a participação dos setores sociais inferiores assumiu cunho "classista" em consequência da existência de uma classe operária numerosa, política e sindicalmente organizada. No Brasil, o avanço da urbanização com relação à industrialização acarretou a concentração de grandes massas populares não operárias nas grandes cidades. As características contemporâneas da tecnologia industrial, de capital intensivo, não permitiram a absorção destas massas no setor secundário. Formou-se, nos centros urbanos, uma população pobre, extremamente heterogênea do ponto de vista socioprofissional, que não se vincula diretamente ao sistema de produção fabril. As ideologias socialistas e proletárias que assinalaram a emergência da classe operária nos países de velha industrialização dificilmente poderiam reproduzir-se nas condições do desenvolvimento brasileiro. O proletariado fabril representa uma facção minoritária relativamente favorecida em comparação com os estratos urbanos pobres não empregados na indústria e em comparação com as populações rurais. Neste contexto, a intervenção das camadas inferiores na política nacional tomou a forma de movimentos populares, policlassistas, frouxamente estruturados, sem programas e ideologias claramente definidos, através dos quais transpareceu o descontentamento de tais camadas contra o status quo e contra os "ricos". Suas reivindicações e exigências não se organizaram em torno dos problemas fabris; os grupos operários que integraram esses movimentos não se sentiam "produtores" "expropriados" e suas aspirações não se localizaram fundamentalmente no plano da indústria e da produção, mas no da cidade e no do consumo.

tornam demasiadamente razoáveis e perdem o contacto com as massas recentemente mobilizadas que afluem do campo ou que estão despertando de um sonho milenário nas próprias cidades". Torcuato DI TELLA, "Populismo y Reforma en América Latina", Desarrollo Económico, Buenos Aires, janeiro-março de 1961, vol. 4, n. ${ }^{\circ} 16$.

${ }^{18}$ A consciência de produtor, de criador de riquezas, dificilmente pode surgir entre o proletariado moderno nas atuais condições tecnológicas e da organização do sistema de trabalho e de produção. O seguinte trecho de A. CHINOY, sobre os trabalhadores de uma indústria automobilística norte- americana, resume bastante bem os empecilhos que se opõem à formação de uma "consciência de produtor", ou de "criador de riquezas" entre os operários submetidos ao trabalho em série: "Embora os operários da indústria automobilística, como muitos outros operários industriais, possam reconhecer o produto final para o qual contribuíram, sua contribuição é tão pequena em consequência da divisão do trabalho, e tão insignificante em consequência da substituição da habilidade manual por máquinas, que os laços psicológicos entre o operário e o produto são tão tênues que podem ser considerados sem significado". Ely CHINOY, Automobile Workers and the American Dream, p. 85.
Dois fatores respondem mais diretamente pelo fato de a participação operária na vida política brasileira efetuar-se sob a forma de movimentos populistas e não de classe (no sentido marxista): em primeiro lugar, a preponderância das exigências socioeconômicas sobre as socioprofissionais, ou seja, das que se localizam antes na área do consumo do que na da produção e do trabalho ${ }^{19}$ em segundo lugar, a debilidade política e sindical das camadas operárias, decorrência, entre outras causas, de seu fraco peso específico no conjunto da população, da pressão constante do excesso de mão de obra, que reduz o valor do fator trabalho e o poder de barganha dos setores assalariados. Em tal contexto, a orientação populista, acompanhada da crença nas virtudes protetoras e onipotentes de lideres de extração social não operária (como Vargas, Adhemar de Barros, João Goulart, Jânio Quadros, etc.) expressou a incapacidade dos trabalhadores de efetuarem por si mesmos uma mobilização autônoma de largo alcance com vistas à obtenção de suas exigências enquanto camada social diferenciada. Indubitavelmente, a crença nos poderes dos líderes populistas envolve um forte componente tradicional de tipo carismático. Mas, em parte, houve a própria fraqueza do movimento operário brasileiro e o fato de que um conjunto de reivindicações que sensibilizam mais de perto os trabalhadores encontra poderosos obstáculos para ser alcançado através de uma ação direta e independente da classe, em negociações e conflitos com os grupos empresariais. Vem daí, por exigências estruturais e econômicas, a inclinação das massas populares por regimes fortes, levando- as, igualmente, a depositar suas esperanças em líderes políticos capazes - graças à manipulação das instituições estatais - de agir sobre questões que ultrapassam de longe a capacidade de atuação das associações operárias: contenção da inflação, aceleração do desenvolvimento, ampliação do sistema educacional, problemas urbanos, como moradia, transporte, etc.

Os dados da investigação na área do comportamento político sugerem uma relação entre as seguintes variáveis: preferência por soluções autoritárias, quanto ao regime, e tendências políticas mais radicais e "esquerdizantes". Em outras palavras: os que optam por uma ditadura estão mais inclinados a apoiar movimentos populistas de "esquerda", fato que indica claramente o sentido da preferência por regimes ditatoriais. Essas

${ }^{19}$ Cf. A TOURAINE: "Industrialisation et Conscience Ouvriere à São Paulo", Ouvriers et Syndicats d'Amerique Latine. 
orientações são mais pronunciadas entre os grupos operários de menor remuneração e recentemente chegados à cidade, isto é, entre os trabalhadores de origem agrícola. Assim, são precisamente os setores que oferecem os maiores índices de abstenção eleitoral os que, comparativamente, se inclinam mais acentuadamente por soluções políticas de tipo "esquerdizante", "nacionalista", cujo conteúdo e sentido explicitaremos mais adiante.

Tabela 52: "Se o Sr. tivesse que escolher entre o Lacerda e o Brizola para Presidente da República, em quem o Sr. votaria?"

\begin{tabular}{|l|c|c|c|c|}
\hline & Operários & Ferramenteiros & Mod. & Trad. \\
Brizola & $53 \%$ & $56 \%$ & $43 \%$ & $70 \%$ \\
Lacerda & 16 & 22 & 14 & 5 \\
Em branco & 31 & 22 & 43 & 20 \\
Nunca ouviu falar nos políticos mencionados & & - & - & 5 \\
& $(100 \%)$ & $(100 \%)$ & $(100 \%)$ & $(100 \%)$ \\
$\mathrm{n}=$ & 62 & 24 & 22 & 20 \\
\hline
\end{tabular}

(*) Tomamos Carlos Lacerda e Leonel Brizola como representantes extremos de orientações políticas antagônicas e radicalizadas nas suas respectivas posições, no momento em que os questionários foram aplicados. O primeiro aparecia como o "anti-Getúlio" por excelência, candidato de forte penetração nas classes médias e ricas, tendo como plataforma ideológica a luta contra a corrupção e o "anticomunismo"; o segundo era o nacionalista radical. Não importa, para nossos fins, a discussão do mérito e do conteúdo das respectivas ideologias. Importa-nos, apenas, como apareciam aos olhos do eleitorado brasileiro.

Confirmando os resultados de outras pesquisas, ${ }^{20}$ a penetração de Carlos Lacerda - então ligado a ex-UDN - entre os setores operários era bastante minoritária. Leonel Brizola, identificado com as posições nacionalistas e trabalhistas, qualquer que seja o setor operário, sem sombra de dúvida encontrava maior receptividade. $\mathrm{O}$ aspecto importante, contudo, são as variações evidenciadas entre os operários comuns e ferramenteiros, e entre Mod. e Trad.

${ }^{20}$ Para a análise da penetração eleitoral dos principais partidos políticos brasileiros nas diferentes camadas sociais, consulte-se: Gláucio A. Dillon SOARES, "Classes Sociais, Strata Sociais e Eleições Presidenciais de 1960", Sociologia, S. Paulo, setembro de 1961; "As Bases Ideológicas do Lacerdismo", Revista Civilização Brasileira, Rio, setembro de 1965, e "Alianças e Coligações Eleitorais: Notas para uma Teoria”, Revista Brasileira de Estudos Políticos, Belo Horizonte, julho de 1964; Cf. também: Orlando M. de CARVALHO, "Os Partidos Nacionais e as Eleições Parlamentares de $1958^{-}$e Oliveiros S. FERREIRA, "Comportamento Eleitoral em São Paulo", Revista Brasileira de Estudos Políticos, Belo Horizonte, abril de 1960; e Francisco Pedro de COUTO, O Voto e o Povo, Rio, Civilização Brasileira, 1966.
Tomando como ponto de referência a qualificação profissional - ou seja, a comparação entre os ferramenteiros e os operários comuns - parece não haver diferença significativa entre ambos os setores, no que tange à conduta política, equacionada de acordo com o maior ou menor radicalismo. Com feito, se $56 \%$ dos ferramenteiros preferiam L. Brizola (quando chamados a optar entre este político e C. Lacerda) contra 53\% dos operários, encontramos uma proporção ligeiramente maior de "lacerdistas" entre os ferramenteiros do que entre os operários (22\% e 16\%). Como se vê, as discrepâncias aqui são pequenas. Outros dados, porém, levam-nos a sugerir a hipótese de que os ferramenteiros, no seu conjunto, inclinam-se mais acentuadamente em favor de candidatos "centristas", cuja tônica programática e ideológica recaia sobre a "eficiência", "realização", "desenvolvimento" e "trabalho". Assim, quando se indagou qual seria o "melhor candidato para a Presidência da República", Juscelino Kubitscheck foi o candidato preferido por $44 \%$ dos ferramenteiros (grupo no qual teve a maior penetração eleitoral), seguido por Carvalho Pinto, com $24 \%$ das preferências. Por outro lado, nenhum ferramenteiro designou L. Brizola como o candidato ideal, embora o único entrevistado que tenha citado o dirigente comunista Luís Carlos Prestes se encontre nessa categoria profissional (ver Tabela 53). Entre os operários, L. Brizola conta com maiores simpatias (7\%), enquanto Carvalho Pinto, caracterizado como político moderado e realizador, gozando de grande prestígio entre os ferramenteiros, mereceu apenas $5 \%$ das preferências.

Jânio Quadros, entre os operários, tinha maior penetração do que entre os ferramenteiros: $31 \%$ e $18 \%$, respectivamente, o indicaram como o melhor candidato à Presidência da República. Apesar disso, Juscelino Kubitscheck é o político que gozava de maior prestígio entre os entrevistados no seu conjunto, chegando a superar ligeiramente Jânio Quadros, inclusive entre os operários (32\% e $31 \%$ das preferências). Provavelmente, o fato de se tratar de trabalhadores de uma empresa automotriz, cuja criação se relaciona com o período de governo do expresidente Kubitschek, responda em grande parte por sua maior popularidade no grupo estudado.

Capítulo a parte constitui a interpretação comparativa das respostas dos Mod. e Trad. Inicialmente, convém destacar que, quando colocados ante a alternativa de optar entre C. Lacerda e L. Brizola, 70\% dos Trad. disseram preferir L. Brizola e apenas $5 \%$ optaram por C. Lacerda. Temos aqui as mais 
altas porcentagens de preferência por L. Brizola e, inversamente, a mais baixa proporção de "lacerdistas". Entre os trabalhadores de origem urbana, a preferência por $\mathrm{L}$. Brizola não chegou a 45\%; a porcentagem de "lacerdistas" foi mais elevada (14\%) e a de indivíduos que prefeririam votar em branco chegou a $43 \%$. Por outro lado, no que tange à indicação do candidato ideal para ocupar a Presidência de República, Juscelino Kubitschek foi escolhido por $45 \%$ dos Trad., seguido por Jânio Quadros (20\%) Leonel Brizola (10\%), João Goulart (10\%), C. Lacerda (5\%) e Adhemar de Barros (5\%). Entre os Mod., igualmente, Juscelino Kubitschek era o candidato preferido, embora por uma porcentagem relativamente menor de entrevistados: $35 \%$. Seguiam-se-lhe Jânio Quadros (25\%), Adhemar de Barros (10\%), Carvalho Pinto (10\%) e Leonel Brizola (5\%).

Tabela 53: "Quem seria, na sua opinião o melhor candidato à Presidência da República?"

\begin{tabular}{|l|c|c|c|c|}
\hline & Operários & Ferramenteiros & Mod. & Trad. \\
Juscelino Kubitschek & $32 \%$ & $44 \%$ & $35 \%$ & $45 \%$ \\
Jânio Quadros & 31 & 18 & 25 & 20 \\
Adhemar de Barros & 9 & - & 10 & 5 \\
Leonel Brizola & 7 & - & 5 & 10 \\
Carvalho Pinto & 5 & 23 & 10 & - \\
Carlos Lacerda & 2 & - & - & 5 \\
João Goulart & 2 & - & & 10 \\
Luis Carlos Prestes & - & 5 & - & - \\
José Bonifácio Coutinho & - & 5 & 5 & - \\
Ninguém & 3 & 5 & & 10 \\
Não sabe & 7 & - & 10 & 5 \\
Outros & 2 & & & - \\
n = & 62 & 24 & 22 & 20 \\
Sem resposta: & $7 \%$ & $8 \%$ & $9 \%$ & - \\
\hline
\end{tabular}

Obs.: Porcentagens extraídas excluindo-se os que não responderam.

A classificação das orientações políticas em termos de "esquerda", centro" e "direita", no contexto político brasileiro, é sempre difícil de ser estabelecida com exatidão e pode prestar-se a muitas controvérsias. Desde logo, ela não corresponde rigorosamente às divisões políticas clássicas que nos deram as décadas finais do século passado e as primeiras do século $\mathrm{XX}$, na Europa. Lá, tipicamente, a Esquerda esteve ligada a partidos que buscavam apoiar-se na classe operária, tendo o socialismo (quaisquer que fossem seus matizes) como programa. Transpor tais conceitos para o ambiente brasileiro não expressaria inteiramente a divisão das forças políticas e sociais. Nós os estamos utilizando no sentido corrente, tal como se popularizaram nos últimos anos, tendo como marcos de referência questões como a reforma agrária, a política externa, a estatização e a participação do Estado na economia, etc. É óbvio que, na ausência de partidos políticos de ideologias e programas mais definidos, a precisão dos conceitos não pode ser muito rigorosa. Deve-se ter em conta, demais, que frequentes vezes líderes políticos, convencionalmente classificados à "direita" (ou à "esquerda"), ante uma questão particular, se encontram em posições semelhantes. Parece claro que as divisões políticas afastam-se das linhas de estruturação socioeconômica e os diferentes estratos socioprofissionais não se expressam politicamente de modo homogêneo. Os agrupamentos político-partidários muito esquematicamente representam as divisões de classe da sociedade global. Nestas condições, também o sentido do apoio prestado pelo eleitor a este ou aquele candidato varia substancialmente. Contudo, feitas essas ressalvas relativas às bases sociais dos movimentos político, estaremos chamando de esquerdistas as correntes ou agrupamentos partidários que proclamavam a necessidade de incrementar a participação do Estado na economia, de realizar a reforma agrária, a sindicalização rural, a nacionalização de empresas estrangeiras, e um conjunto de medidas de cunho igualitário e democratizante a fim de permitir uma maior participação popular na política nacional e estimular o desenvolvimento industrial. Estaremos chamando de direitistas as correntes políticas que punham ênfase num desenvolvimento econômico baseado na empresa privada (nacional ou estrangeira), na diminuição da participação do Estado na economia, na aproximação com os Estados Unidos, na restrição, aberta ou velada, à participação ampliada dos setores populares na luta política, etc. Para os propósitos de uma análise da política nacional e das forças em presença, essas considerações são inteiramente insuficientes, mas parecem bastar para os objetivos que temos em mira, ou seja, a avaliação das orientações políticas dos trabalhadores estudados. Assim, deste prisma, Leonel Brizola pode ser considerado como "esquerdista" e Carlos Lacerda sobretudo quando os questionários foram aplicados - como "direitista". As pesquisas eleitorais mostram que o primeiro recrutava a massa de seus eleitores nos estratos sociais inferiores e, o segundo, principalmente nas camadas médias acomodadas. Não parece arbitrário, portanto, considerar que o voto a Brizola indica uma orientação mais esquerdista e o voto a Lacerda uma orientação mais direitista. 
Essas considerações, um tanto longas e possivelmente desnecessárias, tinham como escopo precisar os termos para a discussão que se segue. Os dados da pesquisa na Empresa Automobilística indicam uma preferência por L. Brizola claramente mais pronunciada entre os trabalhadores recentemente chegados de áreas tradicionais. De certo modo, poder-se-ia dizer que suas orientações políticas se situam ligeiramente mais à esquerda do que à dos demais trabalhadores, principalmente dos nascidos e educados na capital paulista. A mesma afirmação é válida com referência aos ferramenteiros, ou seja, aos setores operários mais qualificados. Lembramos, por outro lado, que também ante a greve operária os Trad. mostravam posições mais radicais ou "esquerdizantes", enquanto os Mod. eram comparativamente mais propensos a repudiá-la enquanto forma de pressão sobre as empresas e mais céticos quanto à sua utilidade enquanto instrumento de luta para a obtenção de aumentos de salários e melhoria do padrão de vida.

Notemos, entretanto, que as porcentagens mais elevadas de abstenção eleitoral foram encontradas entre os trabalhadores de migração recente. São essas camadas, igualmente, as que entendem e consideram os sindicatos basicamente como organismos de assistência médica, apresentando índices de sindicalização inferiores aos dos ferramenteiros. Notemos, também, que são esses setores os que, comparativamente, mais se inclinam a favorecer regimes autoritários, como bem revelam as altas porcentagens de respostas indicando uma ditadura como a melhor maneira de se obter a elevação do padrão de vida dos operários e a aceleração do desenvolvimento econômico.

Temos, destarte, o seguinte quadro: são os setores operários de menor qualificação profissional, menos integrados na sociedade industrial e possuindo menores possibilidades de pressão sobre as empresas os que se inclinam mais acentuadamente a apoiar posições políticas esquerdizantes. Indicamos anteriormente que esses setores operários são os mais desencantados e pessimistas, os que têm escassas possibilidades de lograr a realização do projeto de ascensão social ou de melhoria de vida por meios individuais. Seu descontentamento os leva a optar por soluções radicais como meio de defesa no meio urbano e industrial. Mas essas opções não se traduzem em atos. Seu baixo nível educacional, sua inexperiência quanto ao modo de vida nas grandes cidades, sua alta rotatividade profissional, sua deficiente qualificação técnica, lhes confere limitadas possibilidades de intervenção política autônoma. A preferência por soluções políticas aparentemente mais radicais ou esquerdizantes está acompanhada de um sentimento de insegurança e impotência, de incapacidade de agir e modificar, ainda que seja em pequena escala, uma teia de determinações sociais e econômicas, cujos mecanismos não chegam a discernir de modo mais coerente. A preferência por regimes autoritários vem daí: pensam numa ditadura paternalista que proteja os pobres contra os poderosos e ricos.

O sentido da simpatia por Brizola ajuda a compreender melhor (e a matizar) as orientações mais esquerdistas dessas camadas operárias. As razões do apoio ao ex-governador gaúcho raramente são explicitadas em termos de "nacionalismo", ou seja, como uma opção ideológica e política claramente formulada, contraposta a outra orientação, tal como se encontra habitualmente nos grupos politizados e intelectualizados das camadas médias. Embora não se possa descartar a hipótese de dificuldades de verbalização das razões das preferências por L. Brizola, parece-nos que elas advêm essencialmente do fato deste político aparecer como um "amigo do povo", tal como João Goulart, Jânio Quadros e outros líderes populistas. Os elementos programáticos e teóricos subjacentes, na grande maioria dos casos, não são enfatizados. L. Brizola é, sobretudo, um "protetor dos trabalhadores", enquanto C. Lacerda é um "inimigo". O elemento verbalizado raramente é a identificação com uma posição política determinada (o nacionalismo, no caso) mas a crença de que, votando em L. Brizola, estariam mais protegidos, mais defendidos contra os ricos. A isso cumpre acrescentar a antipatia a $\mathrm{C}$. Lacerda, que os entrevistados sentem como um candidato dos grupos superiores, dos "outros". Desse ângulo, é indiscutível que a opção por Brizola revela um sentimento - embora vago e de contornos pouco precisos - de hostilidade aos grupos sociais superiores. Faz-se mister, portanto, entender o "esquerdismo" dos grupos operários de migração recente (na verdade, não só desses grupos) à luz das considerações acima e não como a adoção teórica e programática de uma posição política claramente definida.

"No Lacerda eu não votaria. No Brizola talvez. Lacerda só faz agitação. Parece que ele vê os pobres como porcos".

"O Lacerda não presta. É um cangaceiro".

"O Lacerda é muito encrenqueiro. O Brizola é muito amigo dos pobres".

"Não votaria no Lacerda, culpado da morte do Getúlio. Esse motivo para mim já basta. Brizola é melhor porque nunca ouvi falar mal dele e do Lacerda sim".

"Prefiro o Brizola. O Brizola parece ser mais aliado com o povo". 
O descontentamento com relação ao status quo, vinculado à incapacidade de agir politicamente de modo autônomo e a inexistência de instituições mediante as quais as intervenções dos setores recém- integrados ou em fase de integração à sociedade industrial possam efetuar-se de modo relativamente sistemático, deixa perceber que estamos ante massas facilmente mobilizáveis (e manipuláveis) desde que haja proteção e estímulos vindos "de cima". Encontramos, portanto, três elementos relacionados: I) a preferência por governos autoritários (de tipo populista); II) apoio a soluções político-sociais mais radicais; e III) possibilidades restritas de intervenção política autônoma.

A aspiração de integração à ordem competitiva e ao mesmo tempo o baixo padrão de consumo, a situação de semimarginalidade, a percepção instrumental e externa da sociedade industrial por parte dos grupos operários de formação recente (especialmente dos que acabaram de abandonar o meio rural) atuam conjugadamente no sentido de fixar suas exigências quase exclusivamente no terreno do consumo e da assistência em detrimento de outras reivindicações referentes ao controle das decisões políticas e às formas do crescimento econômico. Esses setores têm sido, destarte, causadores de desequilíbrio do status quo político e social mais pela pressão relativamente forte (ante as precárias possibilidades atuais do sistema produtivo) que efetuam em favor de medidas distributivas e assistenciais do que pela afirmação de uma alternativa positiva de reorganização dos fundamentos estruturais do sistema. Neste contexto, a entrada das classes populares na vida política nacional, sobretudo na proporção em que vigoram os mecanismos institucionais que possibilitam o populismo, tende a favorecer a criação de um clima social propício a toda sorte de demagogia redistributiva - ou falsamente redistributiva - em prejuízo das alternativas que colimem a longo prazo o incremento da produção, a liquidação dos "pontos de estrangulamento" da economia brasileira, a participação mais democrática dos setores populares nas decisões relativas aos rumos a serem imprimidos ao desenvolvimento do país. Por outro lado, estimula as configurações político-partidárias cujo traço mais marcante da vinculação com os grupos recentemente mobilizados recai tipicamente na denúncia abstrata das "falhas" mais superficiais do funcionamento do sistema, conjugada a promessas de benefícios a serem outorgados na esfera do consumo.
A preocupação com matizar as diferenças observadas nas orientações políticas dos entrevistados, de acordo com a qualificação profissional, origem social, etc., não deve levar a obscurecer suas orientações mais gerais. É certo que, se obrigados a optar entre um radicalismo de direita, encarnado então por C. Lacerda, e um nacionalismo de esquerda, do qual L. Brizola aparecia como um dos líderes mais conhecidos, a ampla maioria dos respondentes optaria por essa última alternativa. Entretanto, no conjunto, L. Brizola não consegue uma penetração e apoio expressivos. As preferências vão esmagadoramente para Juscelino Kubitscheck e para Jânio Quadros, quer entre os operários comuns e os ferramenteiros, quer entre os trabalhadores nascidos nas grandes cidades, e os de migração recente da agricultura ou pequenas cidades do Nordeste. Em outras palavras: as preferências vão, em sua maioria, para os políticos populistas menos radicais ou "esquerdizantes", como, aliás, estão a demonstrar os resultados eleitorais.

\section{CARACTERÍSTICAS DA INDUSTRIALIZAÇÃo E CONSCIÊNCIA OPERÁRIA}

O termo consciência de classe introduziu-se no vocabulário corrente pela extensão da influência do marxismo. Contudo, tal como ocorre com o conceito de classe - com o qual está relacionado - carece de maior precisão, em parte porque o próprio Marx não se dedicou a ele de modo mais sistemático, e, em parte, porque outros autores, inclusive os cientistas sociais, passaram a utilizá-lo com variada significação e de acordo com suas respectivas definições de classe social. Apesar disso, o conceito como é utilizado generalizadamente (embora nem sempre com o devido rigor) traz a marca de origem e se mostra particularmente relevante quando se estudam grupos operários. ${ }^{21}$ Neste sentido, a consciência de classe não deve ser entendida como a mera consciência de identificação com uma classe, como surge em Centers, ${ }^{22}$ não sendo tampouco redutível à consciência coletiva dos operários (como dá a entender Gurvitch $^{23}$ ).

\footnotetext{
${ }^{21}$ Embora se possa, da perspectiva do marxismo, referir-se à consciência de classe da burguesia (falsa consciência, segundo Lukacs), o conceito está mais vinculado ao proletariado, uma vez que implica a tomada de consciência, não apenas dos interesses do grupo enquanto tal como também de uma "exploração" da classe operária pelos detentores dos meios de produção.

${ }^{22}$ Richard CENTERS, The Psychology of Social Classes, Nova York, Russel \& Russel, 1961. Segundo o autor, é a consciência de classe que responde pela existência da classe, pois
} 
Nós a entenderemos aqui no sentido de A. Touraine: “... a consciência de classe supõe a união de três elementos: a afirmação de si, quer dizer, de um princípio de reivindicação; a oposição a quem detém o poder sobre o trabalho; a referência a uma sociedade cujas relações sociais entre a classe dominante $\mathrm{e}$ os trabalhadores constituem um elemento fundamental". ${ }^{24}$ Distingue-se, assim, um principio de totalidade que é a "consciência da sociedade, a concepção da organização social como um sistema de poder controlando a utilização do trabalho e a repartição de seu produto"; um princípio de identidade, ou seja, "a consciência de si, o sentimento de oferecer um fator de produção essencial, o trabalho"; e um princípio de oposição, que é o reconhecimento do adversário, a oposição aos que detêm um poder sobre o trabalho. ${ }^{25}$ Esses três elementos, como observa o autor, nem sempre podem encontrar-se reunidos: a consciência de pertencer a um grupo social determinado pode não se acompanhar de uma "consciência hostil ao grupo patronal", isto é, pode não estar associada ao princípio de oposição. Pode ocorrer igualmente que os trabalhadores tenham a consciência da "exploração patronal" sem que definam a si mesmos como membros de uma classe. Seria possível, ainda, conceber uma situação em que coexistam uma consciência de pertencer a um grupo específico e a consciência do antagonismo sem a presença de uma visão da totalidade social, ou seja, de "um princípio central de funcionamento da sociedade". A partir desses elementos, o autor define além da consciência de classe, 1) uma consciência proletária, que seria pura consciência de oposição, pura negação não referida a nenhum princípio positivo de reconstrução social e de afirmação de classe e II) uma consciência popular, característica de uma sociedade

"uma classe social não é senão aquilo que as pessoas coletivamente pensam dela" (p. 78). As classes não teriam existência objetiva, ao contrário dos estratos sócio-profissionais.

${ }^{23}$ Georges GURVITCH, El Concepto de Classes Sociales de Marx a Nuestros Dias, Buenos Aires, Ediciones Galatea-Nueva Visón, 1960, 2. ${ }^{\circ}$ ed.

${ }^{24}$ Alain TOURAINE, La Conscience Ouvrière, Seuil, Paris, 1966, p. 95. Sublinhado por nós. Quiçá possa parecer estranho que, lidando com um conceito ligado à teoria marxista, deixemos de lado os trabalhos de Lukacs, o autor clássico do assunto. Mas o tratamento que este dá à questão, a nosso ver, além de implicar um a priori ideológico impede a utilização sociológica do conceito, observação, aliás, ociosa pois Lukacs deixa claro que a consciência de classe, para ele, não se apresenta como uma questão de "interesse sociológico geral". Cf. Georg LUKACS, Histoire et Conscience de Classe (cap. "La Conscience de Classe'), Paris, Minuit, 1960.

${ }^{25}$ Ibid., passim. protoindustrial..$^{26}$ Aqui a noção de povo ocupa um lugar central. Ela permite unir "todos os que trabalham contra uma minoria de exploradores e parasitas. Não é na empresa que ela se forma mais facilmente, mas antes na cidade, no quarteirão popular, muito heterogêneo, em que operários, comerciantes, artesãos, pequenos empresários se acotovelam e se misturam, como nos velhos bairros "populares" de Paris ou de Londres, opondo-se em conjunto aos habitantes dos "bairros grã-finos". 27

A pesquisa de Touraine constitui uma tentativa original - a única que conhecemos - de tratar o tema em níveis sociológicos, apoiado no estudo empírico de seis categorias profissionais operárias. Deste ângulo, a consciência de classe desvincula-se de uma concepção ideológica e doutrinária ao mesmo tempo em que não se confunde com os estados psicológicos dos operários. Ela constituiria uma forma particular de expressão da consciência operária ${ }^{28}$ e surgiria num momento determinado da evolução do sistema de produção capitalista-industrial: no momento do encontro do ofício operário com a organização industrial, medeando a passagem de um sistema profissional a um sistema técnico de trabalho.

É a entrada no sistema técnico de trabalho que transforma (...) o princípio de totalidade. De agora em diante pode nascer a ideia de uma sociedade, de uma ordem industrial. Ao mesmo tempo, no momento desta entrada, ao menos em numerosos casos, o princípio de identidade e o princípio de oposição conservam suas formas tradicionais: o operário defende seu ofício ao mesmo tempo profissional e economicamente, enquanto ataca o lucro e o poder dos capitalistas. Se o operário não pode apoiar-se sobre seu ofício, como é o caso dos operários especializados no trabalho em série, esta união complexa desmorona-se e dela só subsiste uma hostilidade a respeito

\footnotetext{
${ }^{26}$ Por sociedade protoindustrial entende-se a sociedade em que a "indústria ocupa já um lugar técnico e econômico importante, mas em que as relações sociais permanecem fundamentalmente dominadas por concepções pré- industriais". Op. cit., p. 311.

${ }^{27}$ Op. cit., p. 312.

${ }^{28} \mathrm{O}$ autor define a consciência operária como "o sentido dado a uma situação na qual os operários estão colocados ante os empregadores num sistema de produção", ou seja "o sentido dado à experiência profissional, econômica, social e cultural do trabalho". A consciência operária define assim um "sistema de reivindicação e exigência com relação ao trabalho". Op. cit., passim.
} 
do empregador e, ao mesmo tempo, o desejo de aumentar o salário ante o qual o interesse pelo trabalho é sacrificado. ${ }^{29}$

Definida a consciência de classe como abrangendo uma consciência de identidade, uma consciência do outro e uma consciência da ordem industrial - tal como a entende Touraine - o problema subsequente consiste na possibilidade de sua captação em termos de investigação empírica. Em outras palavras: Que elementos podem ser tomados operacionalmente como indicadores de consciência de classe? No caso específico dos trabalhadores da Empresa Automobilística, as respostas ao questionário, aliadas às entrevistas informais e às palestras com os trabalhadores permitem-nos chegar a alguns resultados e avançar algumas hipóteses mais gerais relacionados ao proletariado brasileiro no seu conjunto. Para tanto, três áreas de investigação devem ser distinguidas: I) a relacionada à consciência do grupo e que se manifesta nas atitudes ante as associações profissionais e na definição do que significa ser operário; II) a consciência do outro, expressa nas atitudes ante a empresa e na definição do "patrão" e III) as percepções e orientações ante a sociedade industrial. Do prisma da terminologia da discussão precedente, essas áreas corresponderiam, respectivamente, aos princípios de identidade, de oposição e de totalidade.

Os capítulos anteriores já oferecem elementos para a avaliação do comportamento ante a empresa e o sindicato. Procuramos mostrar a inexistência de uma "consciência de explorado" e a aceitação, por parte dos trabalhadores, dos objetivos da empresa e, em especial, do lucro. Concretamente: não se encontrou, no grupo investigado, a ideia de um antagonismo separando a empresa e os empregados, o que nos leva a dizer que o "princípio de oposição" é, no melhor dos casos, muito débil. Com relação ao sindicato, os baixos índices de integração e a própria concepção de quais devem ser suas funções indicam um fraco sentimento de identificação com a classe. Em suma: faltam aqui dois dos componentes que concorrem para a estruturação da consciência de classe, tal como a estamos entendendo. Esses dois aspectos podem ainda ser apreciados de outro ângulo, ou seja, através das imagens que os trabalhadores fazem de si mesmos e dos empregadores. Começaremos examinando-as através das respostas à seguinte pergunta: "Na opinião do Sr., que é um operário?". Infelizmente não foi possível estabelecer categorias para a quantificação e

${ }^{29}$ Op. cit., pp. 329 e 330. apresentação das respostas em termos porcentuais. A pergunta era "aberta"; os entrevistadores foram instruídos a não insistir que os entrevistados explicitassem suas definições, mas que anotassem ipsis litteris a primeira resposta oferecida pelos trabalhadores. Como seria de esperar, encontraramse reunidas, numa mesma definição, referências a vários atributos, como seja, o trabalho, a situação de subordinação, de pobreza, de assalariado, etc.

"Operário é um indivíduo que tem que trabalhar todos os dias e nunca pode descansar".

"É uma pessoa que tem que lutar pela vida. Tem que sofrer. Sai cedo de casa".

"Operário é uma das piores coisas que tem. Vida muito difícil, passa muita necessidade".

"É um cara obrigado a fazer tudo, mandado por todo mundo".

"É um indivíduo de classe muito baixa. Não tem estudo. tem que tolerar muita coisa".

"É uma pessoa que vive de salário".

Um aspecto a ser ressaltado é que a menção explícita e única à condição assalariada recebeu fraca porcentagem de respostas. ${ }^{30}$ Por outro lado, a situação de subordinação foi fortemente acentuada, tendo alguns dos trabalhadores equiparado o operário ao escravo. Porém, quaisquer que sejam os atributos em torno dos quais se polarizam as definições, quase todas elas estavam impregnadas da ideia de que o operário é essencialmente um homem pobre, dominado e desprotegido: um "infeliz".

"O operário é um coitado, desprotegido de todos".

A maior parte das respostas define o operário como aquele que trabalha. O operário seria, então, essencialmente, o trabalhador. Mas convém explicitar o sentido que o atributo "trabalho" adquire na definição da grande maioria dos entrevistados. Primeiramente, o trabalho é entendido sempre como manual e, em seguida, como uma atividade cansativa, desagradável, suja, mero dispêndio de esforço físico, obrigatório e nunca devidamente recompensado.

Ora, o fato de a definição de trabalho estar tão estreitamente vinculada a tarefas desagradáveis, a sofrimento, etc., não seria indicativo de

${ }^{30}$ Uma tabulação, separando os que fizeram menção direta à situação de assalariado, mostrou que a proporção não ultrapassou $16 \%$ dos operários e $17 \%$ dos ferramenteiros. 
um repúdio muito acentuado pelas tarefas realizadas? Não mostraria que elas são desprovidas de qualquer atrativo propriamente profissional para aqueles que as perfazem $?^{31}$

Deste modo, a imagem do operário - ainda quando se configura tendo por base o atributo trabalho - identifica-se fortemente com a de pessoa humilde, inculta, que é mandada, que tem de obedecer, que é pobre e por isso tem de trabalhar em serviços rústicos, sujos e desagradáveis, como sintetiza esta definição.

"Operário é um homem pobre que luta pela vida, para ganhar o pão, trabalhando em serviço pesado, em serviço sujo e serviço duro".

Considerando as respostas, nas quais a condição operária é sentida tão negativamente, não seria de se indagar se elas não expressariam uma consciência de oposição, uma visão da sociedade dividida em classes antagônicas? Ocorre, porém, que a ideia de "dominado", de "pobre", de "desprotegido" encobre a consciência operária: em lugar de uma percepção da sociedade dividida em classes sociais (produtores assalariados e proprietários dos instrumentos de trabalho) tem-se, mais exatamente, uma visão da sociedade dividida em níveis sociais, cuias determinações não aparecem vinculadas à esfera do sistema de produção industrial. Para que a consciência de "pobre" e de "trabalhador" pudesse se constituir como um dos componentes da consciência de classe, tal como a estamos entendendo, seria necessário, ao menos, que ela se associasse mais fortemente à consciência de produtor e de assalariado de modo que o capitalista aparecesse como o que se apropria do resultado do trabalho do operário. Mas raramente a imagem do operário identificou-se com a de "produtor". Poder-se-ia pensar que ela estaria implícita na definição do operário como "trabalhador". Contudo, já vimos, o trabalho não é valorizado enquanto "trabalho produtivo", criador de riquezas. Não há, em suma, a valorização do trabalho. À condição operária os entrevistados não associam nenhum elemento positivo, nenhum orgulho pelo fato de pertencerem ao grupo "dos

\footnotetext{
31 Lembrando que esses mesmos trabalhadores valorizam fortemente a Empresa Automobilística (como procuramos deixar claro em capítulo precedente) reencontramos aqui um elemento importante para a compreensão de seu comportamento e atitudes; os trabalhadores valorizam mais o emprego do que o trabalho propriamente dito, ou seja, o salário, as possibilidades de ascensão na empresa, a condução gratuita, o restaurante, etc., e não os aspectos sócio-profissionais correlatos.
}

que produzem". Para tanto, cumpriria existir uma "consciência profissional" (embora esta não se identifique com a consciência de classe) que possibilitasse, através da valorização da tarefa, o desejo de sua afirmação, a necessidade de sua defesa ante o empregador e laços de solidariedade mais estreitos com os companheiros de fábrica. Ocorre que dificilmente esta consciência pode existir entre trabalhadores semiqualificados do trabalho em série cujas tarefas não implicam transformação da matéria, conhecimento das ferramentas ou do equipamento e, do mesmo modo, formação profissional efetiva.

Além disso, seria preciso que, na percepção dos trabalhadores, capitalista, o proprietário dos meios de produção, aparecesse como responsável pela pobreza e submissão dos operários. Em suma: os aspectos negativos da condição operária deveriam estar relacionados à "exploração" (no sentido marxista da palavra), resultado do sistema de produção e de propriedade, a fim de que o grupo capitalista fosse entendido como uma força hostil que, concomitante- mente, submete o trabalhador à sua organização do trabalho orientada para o lucro e se apropria daquilo que o operário produz. Em tais condições, poderia haver coincidência entre a luta pela defesa econômica do operário e a luta pela sua afirmação socioprofissional, sendo, nos dois casos, o "inimigo" localizado numa mesma categoria social. Ora, no caso dos trabalhadores da companhia estudada, em nenhum momento a empresa surge como a responsável pela "miséria" operária. Pelo contrário: vimos que a maioria dos entrevistados considera que a sua situação pessoal melhorou; o emprego na Empresa Automobilística é avaliado como uma via (se não a melhor pelo menos a mais exequível) de realização do projeto de melhorar de vida ou de ascender socialmente. É um meio de escapar dos aspectos negativos da condição operária, ou de atenuá-los. Na percepção dos informantes, a miséria operária não deriva do trabalho fabril, não decorre, melhor dito, da "exploração do trabalho" pelos proprietários capitalistas, mas de fatores sociais e políticos mais amplos que o grupo não sabe discernir com precisão. São explorados porque são pobres e não são pobres porque são explorados. A pobreza, e, mais do que ela, a submissão, aparecem assim como um dado natural que leva ao fatalismo e à resignação. $\mathrm{E}$, ainda que se pudesse falar numa "consciência de explorado" ela não poderia ser identificada a uma consciência de oposição (princípio de negação) uma vez que não se estruturaria em torno dos problemas do trabalho das relações com a camada 
proprietária. Por isso não pode ser definida como "consciência proletária" (tal como a define Touraine) porque, nesta, a pura negatividade é a recusa do presente, ou seja, do capitalismo, enquanto, aqui, a recusa não existe, o que não impede que as reivindicações salariais possam acarretar atritos com setor empresarial, tal como as aspirações de integração na ordem urbanoindustrial podem por em risco o equilíbrio do status quo. ${ }^{32}$

A definição do "patrão" oferece novos elementos para a discussão, possibilitando complementar a imagem que os trabalhadores formam de si próprios.

Diferentemente da pergunta anterior, foi possível, neste caso, estabelecer algumas categorias para a tabulação e apresentação das respostas em porcentagem. A imagem do "patrão" envolve a percepção conjunta de diferenças hierárquicas, de níveis de renda, de tipo de trabalho e posse dos instrumentos de produção. Tabulamos as respostas de acordo com o aspecto que era salientado na definição e que, Obviamente, em algumas respostas, poderia ser mais de um. Tal como no caso da pergunta referente à definição do operário, os entrevistadores anotaram as respostas nas próprias palavras dos respondentes, sendo a pergunta "aberta".

Como percebemos pela análise da Tabela 54, o patrão é entendido basicamente como o que manda por uma proporção elevada de trabalhadores. Nota-se que os Trad. acentuam fortemente as diferenças no nível de renda, ou seja, a dicotomia rico-pobre, enquanto este aspecto quase não é mencionado pelos Mod. (40\% e 9\%, respectivamente). Por outro lado, esses últimos são mais propensos a tomar como critério a posse dos meios de produção e do capital. Os ferramenteiros praticamente não mencionaram as diferenças no tipo de trabalho (trabalho manual em contraposição a trabalho não manual), enquanto uma proporção relativamente elevada de operários $(24 \%)$ o tornaram como ponto de referência.

32 “... o desequilíbrio político da sociedade parece associar-se a tensões latentes puramente sociais, que se polarizam politicamente graças ao teor irracional e egoístico das avaliações daquelas tensões pelos círculos conservadores. Os resultados da investigação histórica e da investigação sociológica sugerem, convergentemente, que tanto o trabalhador agrícola, quanto o operário - para não se falar do negro ou do estudante radical, que também com partilham de motivações análogas - são movidos, socialmente, pelo afã de ter acesso às posições acessíveis na ordem social competitiva, de se classificarem dentro dela de modo estável e de participarem, com a própria família, de seus mecanismos de ascensão social". Florestan FERNANDES, "Crescimento Econômico e Instabilidade Política no Brasil".
Tabela 54: "Na opinião do Sr., o que é um patrão? Em que se diferencia de um operário?"

\begin{tabular}{|l|c|c|c|c|}
\hline & Operários & Ferramenteiros & Mod. & Trad. \\
Acentua as diferenças hierárquicas $^{33}$ & $42 \%$ & $30 \%$ & $31 \%$ & $40 \%$ \\
Acentua as diferenças de nível de renda $^{34}$ & 21 & 17 & 9 & 40 \\
Acentua as diferenças no tipo de trabalho $^{34}$ & 24 & 4 & - & \\
(trabalho intelectual e trabalho braçal) $^{35}$ & 26 & 26 & 41 & 25 \\
Acentua a posse dos meios de produção $^{36}$ & 15 & 13 & 5 & 5 \\
Acentua o trabalho em si mesmo $^{37}$ & 26 & 14 & 18 & 10 \\
Outras respostas $_{\text {Não soube responder }}$ & - & 4 & - & - \\
n= & 62 & 24 & 22 & 20 \\
\hline
\end{tabular}

OBS.: Respostas múltiplas. Soma das porcentagens superior a $100 \%$.

Porém, mais importante do que a classificação formal das respostas é a análise e explicitação de seus significados e conteúdos. Quaisquer que sejam as diferenças salientadas elas são vistas do prisma de um profundo sentimento de inferioridade. Importa salientar que o "patrão" não aparece precipuamente como um "explorador" do trabalho, mas como o rico, o poderoso, o que tem capacidade, o que dispõe das coisas e dos homens, principalmente como o que dispõe de si mesmo, da própria vida. Em contraposição, o operário aparece, novamente, como o que é mandado, o que "sofre", o que trabalha, porque o outro é poderoso, tem mais conhecimentos, mais responsabilidade. Numa palavra: o patrão é rico, o operário pobre.

"O patrão passa bem melhor que o operário. O patrão come bem, come franguinho. O dinheiro sobra para o patrão".

\footnotetext{
33 "O patrão manda e o operário obedece"; "O patrão manda e não pede e o operário tem a obrigação de obedecer"; "O patrão manda, o operário trabalha".

34 "O patrão tem dinheiro, o operário não tem"; "O patrão é rico. Se o operário tivesse dinheiro também poderia ser patrão"; "O patrão tem bastante dinheiro. O operário é pobre. O patrão precisa menos do operário porque tem muita gente desempregada".

35 'O Patrão trabalha com a cabeça. "O operário trabalha com as mãos". "O patrão tem que pensar, o operário, não". "O operário trabalha na produção e o patrão na direção". "O patrão tem conhecimentos muito mais elevados do que os dos operários. Se não fosse assim, a função poderia mudar: o patrão passaria a ser operário e o operário passaria a ser patrão".

36 "A diferença é que o patrão tem o capital, é dono, tem a palavra". "O patrão tem o capital e o operário não tem nada". "O patrão é capitalista e o operário é que constrói o capital do patrão". 37 "O operário trabalha sempre, o patrão só trabalha quando quer". "O operário trabalha e não tem problemas. O patrão não trabalha e tem problemas".
} 
"O operário é quem sofre. O patrão é o que dá em cima. O pobre como arroz com feijão. O rico tem tudo".

"O patrão pode dar boa educação para os filhos; pode ir a lugares que o operário não pode".

Além disso, o patrão é poderoso, pode dispor da vida dos operários:

"O patrão é dono da companhia e dos operários. É a mesma diferença entre um rei e um súdito".

"O patrão manda e o operário tem que obedecer senão ele pode ser despedido".

"O patrão é o dono da firma, pode fazer o que quer, e o operário tem que obedecer e cumprir suas obrigações".

A crença no poder do patrão alia-se, amiúde, à ideia de "responsabilidade" e de "capacidade" patronal. Aos operários cumpre obedecer porque o rico que manda "sabe o que faz", tem conhecimento e instrução superiores aos dos trabalhadores.

"O patrão tem mais capacidade que o operário. Ele sabe o que faz e ele manda".

"O patrão é uma pessoa de maior capacidade, é uma pessoa que sabe mais do que o operário. O patrão tem todo o conforto que o operário não tem".

"O patrão tem mais preocupação e problema. O operário só tem o problema de trabalhar".

Novamente, encontramos na análise das definições do patrão uma percepção de diferenças sociais mais do que de diferenças de funções ou de posição no sistema de produção. Talvez fosse possível falar aqui de uma consciência de oposição que não tem como referência direta e básica a divisão dos grupos sociais determinada pela ordem econômica, mas diferenciações decorrentes de poder, riqueza, mando e instrução. Assim, o operário, quando caracteriza o patrão como o rico, o que manda, e o identifica com todos os demais membros das camadas superiores, identifica a si próprio menos com o seu grupo socioprofissional e mais com a massa, profissionalmente variada, dos que trabalham, dos que têm pouca instrução e recebem salário baixo, dos que são pobres. ${ }^{38} \mathrm{~A}$ identificação far-se-ia, pois, com os que, no plano do consumo de bens materiais e culturais, situam-

\footnotetext{
${ }^{38}$ Esta mesma forma de consciência popular foi notada por Juarez Brandão Lopes entre os operários da fábrica que estudou. Cf. Sociedade Industrial no Brasil, p. 67.
}

se em nível relativamente semelhante. Em outras palavras: o trabalhador identifica-se mais com os que partilham formas de consumo relativamente semelhantes do que com os que realizam o mesmo tipo de trabalho.

Mencionamos anteriormente que o outro componente da consciência de classe (o princípio de totalidade) implica uma referência à sociedade industrial, vinculada à afirmação da positividade da classe e de seu papel remodelador da ordem social. Sem esta referência, a consciência de classe seria quando muito uma consciência corporativista, segundo a definição que P. Anderson utiliza para definir a consciência do proletariado inglês, 39 ou seja: uma classe capaz de afirmar-se enquanto grupo ou camada social específica, com forte consciência de si mesma, mas incapaz de se dar uma orientação de reorganização da sociedade inclusiva. Ora, o princípio de totalidade implica, destarte, de um lado, a consciência de pertencer a uma ordem social mais ampla (sociedade industrial) e, de outro, a ideia de que os trabalhadores (enquanto classe, camada ou grupo social distinto dos demais) se vejam como desempenhando um papel essencial no funcionamento do sistema, definindo formas de intervenção autônoma na vida política nacional e, no limite, se dando um projeto próprio, um projeto que sendo determinado pelo modo peculiar de inserção no sistema produtivo, acarrete correspondente orientação política, programática e ideológica. Cumpre, para tanto, que a sociedade industrial seja percebida em termos de um campo de enfrentamento de classes antagônicas, onde a dominação econômica pareça relacionada à dominação política. Pelo que foi possível verificar, os entrevistados não estabelecem essa vinculação. O poder está nas mãos dos que decidem, dos que são poderosos, dos que participam da política. Cabe naturalmente a estas pessoas decidir, sendo julgadas segundo beneficiem ou não ao "povo". São elas, portanto, e não os "patrões" os responsáveis pela situação, pior eu melhor, dos trabalhadores. O universo da política - entendida na sua vinculação estreita com o governo tende a encobrir as determinações econômicas da vida social. O governo é visto como uma espécie de demiurgo. A atenção se fixa nos "homens públicos" e tal como há os "bons patrões", há os "bons governantes". O "explorador", o responsável pelas dificuldades do povo (entre o qual os operários se incluem) é "governo", o mais das vezes, os "políticos" e os membros dos corpos legislativos em geral. Espera-se, deste modo, que um "poderoso" proteja e defenda os operários e trabalhadores, o povo", de outros ricos e gananciosos.

\footnotetext{
${ }^{39}$ Ver capítulo anterior.
} 
No grupo estudado, em nenhum momento apareceu a ideia de que caiba à classe algum papel nos processos político-sociais maiores e, $a$ fortiori, que tal intervenção deva trazer a marca da classe, expressada mediante uma ideologia de remodelação social, qualquer que seja seu matiz programático e doutrinário. ${ }^{40}$ Aliás, para tal conclusão não seria necessária qualquer pesquisa deste gênero, mas bastaria refletir sobre os resultados eleitorais, sobre a ausência de movimentos e organizações partidárias de ideologias marcadamente classistas ou de tipo igualitário e coletivista.

Tabela 55: "Algumas pessoas dizem que os sindicatos não devem intervir na política do país; outras dizem o contrário. Qual é sua opinião?”

\begin{tabular}{|l|c|c|c|c|}
\hline & Sindicalizados & Não sindicalizados & Operários & Ferramenteiros \\
Devem & $43 \%$ & $33 \%$ & $36 \%$ & $37 \%$ \\
Não devem & 53 & 59 & 59 & 63 \\
Depende & 4 & 4 & 2 & - \\
Não sabem & - & 4 & 3 & - \\
& $(100 \%)$ & $(100 \%)$ & $(100 \%)$ & $(100 \%)$ \\
& 23 & 63 & 62 & 24 \\
\hline
\end{tabular}

A discussão, de resto, parece desnecessária. Se falta uma consciência de identidade e de antagonismo, definida em relação ao sistema de produção industrial, o grupo operário não pode se propor um projeto próprio da ordem social inclusiva, uma visão da sociedade organizada à sua imagem", pois a imagem que faz de si próprio é negativa e assim sendo não pode se oferecer como modelo. A consciência de pobre - que acompanha a desvalorização do trabalho fabril, entendido como trabalho sujo, desagradável, próprio às categorias inferiores da sociedade - não pode fundar uma alternativa positiva de reconstrução social, embora possa servir de base para a critica do status quo.

Diversos fatores entravam a emergência da consciência de classe em um proletariado formado num processo de industrialização como o brasileiro. Como conclui Touraine, o aparecimento da consciência de classe se dá quando da expansão do sistema técnico de trabalho, onde a consciência de classe "seria o apelo a um princípio profissional de reivindicação opondo-se a um poder social considerado como hostil no interior de um sistema técnico ao qual o operário se sente pertencer e participar.$^{41}$ É necessária a existência

\footnotetext{
${ }^{40}$ Não deixa de ser significativo, neste sentido, o fato de que a maioria dos entrevistados rejeita a simples ideia de uma intervenção dos sindicatos na política nacional, qualquer que seja ela.

${ }^{41}$ Op. cit., p. 88. Sublinhado por nós.
}

anterior de um sistema profissional de trabalho relativamente desenvolvido mediante o qual se possa estruturar uma consciência profissional. A defesa da autonomia do operário no trabalho, a oposição ao sistema técnico quando da implantação da grande empresa ocorre já no interior de uma ordem industrial, o que permite a conjugação dos princípios de identidade, de oposição e de totalidade. Se este contexto técnico-econômico coincide com uma estrutura institucional e jurídica que exclui formalmente a participação dos grupos operários na vida política nacional, aos fatores econômicos e técnicoprofissionais se acrescenta um elemento de exclusão política e social, favorecendo a conexão entre esses elementos. Coincidem a oposição ao sistema de trabalho assalariado que rouba aos operários a autonomia profissional, a propriedade dos meios de produção, o resultado de seu trabalho - com a rejeição do sistema político que lhes restringe o direito de participação na sociedade nacional. Este último aspecto é essencial porque completa a marginalização do trabalhador e permite a vinculação entre os problemas que se dão na esfera do social, do econômico e do político. Mas para tanto é preciso que os operários se sintam participantes e relativamente integrados na sociedade. Esta situação se configura tipicamente nas fases iniciais da formação do capitalismo e da sociedade industrial, de acumulação acelerada de capitais, de mecanização, de concentração da renda e de restrição à participação institucionalizada das camadas assalariadas. Os grupos operários sentem-se como parte da sociedade, de fato participantes, embora esta participação formalmente não seja institucionalizada e aceita pelos grupos superiores. Em suma: trata- se de uma situação prévia à expansão da sociedade de massa, do Welfare State, dos meios de consumo e de comunicação de massas.

Se a formação da classe ocorre num período de desenvolvimento industrial moderno, como é o caso do Brasil, ou seja, no período da produção em massa, da decomposição e desqualificação do trabalho, apelando para uma mão de obra retirada do setor pré-capitalista, ou tradicional, as condições para a emergência de uma consciência de classe, tal como ocorreu na Europa, não existem. Faltam aos grupos operários maior coesão interna, efetiva formação profissional e experiência de trabalho no interior de uma economia predominantemente monetária. Em suma, falta uma massa trabalhadora vivendo já em uma sociedade impregnada pelo racionalismo e individualismo das sociedades voltadas para a produção mercantil sobre a qual incida o impacto do sistema de produção em massa. 
Nas condições do desenvolvimento brasileiro, a sociedade industrial em formação aparece como estranha às massas recém-ingressas na vida fabril. Elas não se sentem responsáveis pelos seus rumos; sua própria integração e participação nos diversos níveis da atividade social é medíocre. $\mathrm{Na}$ Europa, a sociedade industrial foi o resultado do desenvolvimento de forças que atuaram partindo do próprio seio de uma ordem social anterior, enquanto no Brasil a formação parcial do mundo industrial foi o resultado de sua situação de provedor de produtos primários aos mercados mundiais. As áreas de "modernismo" implantaram-se como quistos no interior de uma estrutura socioeconômica pré-industrial ou pré-capitalista, mas não foram o resultado de sua evolução "natural". Nas condições europeias, as populações que adentraram progressivamente o processo de produção capitalista já eram participantes de uma economia predominantemente mercantil e participante, em menor ou maior escala, da vida da nação. A continuação da industrialização afetou negativamente setores sociais relativamente integrados. ${ }^{42}$ Nas condições brasileiras, de desenvolvimento combinado, a constituição da sociedade urbano-industrial processou-se de modo bastante acelerado, mas limitado, em miniatura dir-se-ia, e sem afetar profundamente as populações ligadas à grande lavoura ou economia de subsistência. A industrialização, em "circuito fechado", descompassada com relação ao ritmo de crescimento urbano, criou uma civilização que é ao mesmo tempo estrangeira e atraente para os segmentos populacionais deslocados das áreas pré-industriais. ${ }^{43}$ Assim,

${ }^{42}$ Convém lembrar que a revolução industrial com suas novas técnicas produtivas fora precedida por uma revolução econômica que atingira inclusive a agricultura. Na Inglaterra, a expansão da "indústria doméstica" (da lã, em primeiro lugar) e o incremento das atividades comerciais criaram amplos segmentos populacionais compostos de trabalhadores "independentes" que retiravam sua subsistência (parcial ou totalmente) da produção para o mercado. Em outras palavras: muito antes do reinado absoluto das grandes fábricas e do capitalismo industrial existia uma população integrada economicamente e relativamente participante da vida do país. Nota Mantoux "que na indústria da lã, a mais importante da antiga Inglaterra, a existência de manufaturas propriamente ditas, das grandes oficinas colocadas sob a direção efetiva do capitalista, continua sendo excepcional até fins do século XVIII". Paul MANTOUX, La Revolución Industrial en el Siglo XVIII, Aguilar, Madrid, 1962, p. 46. No mesmo sentido, Cf. T. S. ASHTON, La Revolución Industrial, México, Fondo de Cultura Econômica, 1964.

“... para que unia sociedade se apreenda como um sistema unificado de produção, não basta que massas importantes venham se aglomerar nas cidades e se coloquem no mercado de trabalho industrial; é necessário, ao menos, que a industrialização prepondere sobre a urbanização e que os recém- chegados se definam como trabalhadores e não como migrantes, como habitantes de certos bairros ou como originários de certa região. Esta malgrado a implantação de novas e modernas unidades produtivas, o universo social das grandes cidades acha-se longe de estar plenamente saturado dos modos de ser, pensar e agir das civilizações industriais. Daí a visão instrumentalista dessas massas que habitam a civilização industrial sem dela serem participantes efetivos, procurando aproveitar todas as vantagens possíveis, sem sentir que lhes cabe algum papel relevante numa ordem social para cuja elaboração não contribuíram.

Esta massa de trabalhadores - que não pode apelar a nenhum princípio profissional ou a uma constelação de valores organizada em torno da consciência de produtor - não encontra nenhum obstáculo formalmente instituído para sua participação política, dado que a classe se constitui num período de vigência do populismo, de "autoritarismo popular" e de "democracia social". ${ }^{44}$ Com frequência, os esforços de integração são condição não é fàcilmente realizável. Para tanto é preciso que a sociedade industrial seja
mais do que uma base econômica, que instituições novas ou uni novo funcionamento das instituições tradicionais marquem claramente a importância decisiva para a sociedade de tais transformações econômicas. É necessário, portanto, que exista já certa integração social dos trabalhadores industriais, em particular ao nivel das instituições políticas. A. TOURAINE, La Conscience Ouvrière, pp. 349-350. Sublinhado por nós.

${ }_{44}$ É óbvio que, à luz do que foi dito anteriormente sobre a precariedade dos regimes democráticos no Brasil (e em outros países periféricos), não teria sentido referir-se a um proletariado que surge sob um regime de democracia política clássica. Contudo, quer como resultado de "efeitos de demonstração", quer como requisito indispensável para o estabelecimento da ordem industrial, do Estado nacional e do desenvolvimento, alguns valores democráticos e socializantes se impuseram universalmente. Legislação social, direitos trabalhistas, legalização dos sindicatos, direito de voto aos trabalhadores industriais constituem componentes jurídico-institucionais exigidos para a constituição de uma ordem industrial na presente etapa de progresso técnico e organização da produção. A peculiaridade da evolução dos países subdesenvolvidos reside no fato de que, amiúde, tais medidas estabeleceram-se ou consolidaram-se sob regimes velada ou abertamente autoritários no plano político, quando do esboroamento do velho liberalismo latino-americano. Houve, pois, "uma democratização por via autoritária" (A. TOURAINE, "Industrialisation et conscience ouvrière à São Paulo"). De uma perspectiva diferente de Lipset, vejam-se as considerações de Gino GERMANI sobre as características que marcam a participação popular na América Latina; "El Autoritarismo y las Clases Populares", op. cit., cap. 4 e Florestan FERNANDES, Mudanças Sociais no Brasil (Parte I), São Paulo, Difusão Europeia do Livro, 1960. Para uma apreciação geral do processo de mudança latino-americano e da relação entre as elites tradicionais e o liberalismo, veja-se Tose Medina ECHEVARRIA, Consideraciones Sociológicas sobre el Desarrollo Económico, (Cap. III, "Hacia la Nueva Sociedad") Buenos Aires, Solar-Hachette, 1964. Na mesma direção vão as observações de Celso FURTADO, Dialética do Desenvolvimento, especialmente II Parte, "Diagnóstico da Crise Brasileira", Rio, Fundo de Cultura, 1964. 
controladamente estimulados pelo Estado, em virtude mesmo dos requisitos exigidos por uma política desenvolvimentista na atual etapa tecnológica e de segurança nacional. Este ponto - que não poderíamos desenvolver aqui se relaciona com as forças e grupos sociais que impulsionam a industrialização ou, mais exatamente, que criam as condições sociais e políticas para expansão da sociedade industrial, não mediante a simples direção rotineira das atividades econômicas, mas através da modernização das instituições, da constituição das bases sociais a fim de que a industrialização signifique algo mais do que um simples acréscimo de bens fabricados. Desse ponto de vista, as investigações realizadas indicam que, na superação do subdesenvolvimento, a camada empresarial não tem sido capaz de desempenhar os mesmos papéis dinâmicos e inovadores que assumiu nos países de industrialização mais antiga. No caso brasileiro, parece lícito indagar em que medida os empresários industriais, no nível econômico enquanto camada superior, são capazes de atuar como classe dirigente no plano político nacional. "Em que pese a participação crescente da produção industrial na formação da renda nacional - conclui $\mathrm{F}$. $\mathrm{H}$. Cardoso de suas pesquisas sobre os empresários brasileiros - é restrito o grau de controle político que os industriais exercem, enquanto camada social, sobre o aparelho estatal. Falta à classe dos industriais a socialização necessária para o desempenho dos papeis a que deveriam responder como cidadãos de uma república democrático-burguesa (...) Sentem-se (...) sem responsabilidade pela Nação e definem-se como um grupo alheio às decisões do governo. Dir-se-ia que reificam "o Governo" e o associam a todos os males do país, numa racionalização típica do comportamento das classes medias, às quais se ligam ideologicamente. Por isto mesmo, a participação isolada dos industriais ou de grupos de industriais no jogo político tende a caracterizar-se pelo individualismo, e, muitas vezes, pelo oportunismo: agem para alcançar algum grau de influencia que permita proveitos diretos para si ou para suas empresas". ${ }^{45}$

Ora, ante uma classe burguesa, de um lado, fracamente estruturada e heterogênea, extremamente dependente do capital estrangeiro e dos favores estatais e, de outro, conectada com os grupos superiores tradicionais, sem

\footnotetext{
${ }^{45}$ Fernando Henrique CARDOSO, Empresário Industrial e Desenvolvimento Econômico, Difusão Europeia do Livro, São Paulo, 1964, p. 165. Veja-se também, "Condições e Fatores Sociais da Industrialização em São Paulo", Revista Brasileira de Estudos Políticos, Belo Horizonte, junho de 1961.
}

condições de chamar a si a responsabilidade pelo delineamento de uma política mais audaciosa de expansão e modernização da sociedade brasileira, não caberia indagar se as características da camada industrial em parte não constituem por sua vez um obstáculo para a emergência de uma consciência de oposição entre o proletariado, dado que esta só pode se polarizar em torno da relação com seu oposto nas esferas da produção fabril e da sociedade global? Se a liderança do desenvolvimento e as ações inovadoras das instituições e do aparelho estatal se repartem por outras categorias sociais (setores tradicionais, militares, técnicos, etc.) que não estabelecem com as camadas operárias os mesmos tipos de relacionamento que os grupos industriais, a conexão entre os princípios de totalidade e de oposição se dilui, e os planos econômico (industrial) e político (governamental e administrativo) constituem-se como compartimentos estanques da realidade social, pois a racionalidade da empresa não encontra suportes na racionalidade do Estado e a "classe econômica" não aparece como a "classe política". Os industriais constituem-se, na consciência dos operários, apenas como ricos e não como a classe dirigente. Daí porque a condição operária, por sua vez, aparece como resultado de determinações que partem da área da política e do governo. A consciência de oposição tende a se erigir em relação ao governo (ou à "classe política") e não à camada industrial.

No âmbito de uma contradição e diferenciação muito acentuadas entre dois contextos sociais, polarizados em torno de um setor tradicional e outro moderno, a sociedade urbana (e industrial) exerce forte atração sobre as massas trabalhadoras de formação recente, possibilitando atitudes favoráveis à industrialização e à sociedade capitalista, na proporção em que ambas possam identificar-se. Contudo, a ambiguidade que impregna a orientação das massas trabalhadoras para a indústria concorre para obstar a formação de uma consciência de classe, pois a condição operária é encarada concomitantemente do ângulo do projeto de melhoria de vida e como uma situação passageira, aceita na falta de outras oportunidades profissionais. Assim, mesmo quando o emprego é avaliado positivamente (como no caso dos empregados da Empresa Automobilística), o trabalho fabril é encarado como "desagradável", "sujo" e depreciado. A valorização da indústria é feita em comparação com o trabalho na agricultura, tendo como ponto de referência principalmente os salários. Em certa medida, é um meio para a permanência nas grandes cidades. Da condição operária, valorizam-se basicamente seus elementos "externos", enquanto os aspectos profissionais, os que envolvem 
a relação emocional e pessoal do operário com sua tarefa (e com a organização da empresa) ocupam lugar secundário. A perspectiva "instrumentalista", em que o trabalho fabril é mais do que tudo um meio para o atingimento de alvos que se situam na sociedade inclusiva, unida à valorização do emprego e não da profissão, da sociedade industrial e não da condição operária, resulta numa medíocre consciência de identificação com o grupo socioprofissional, suporte essencial para o aparecimento de consciência de classe.

Em tais condições, parece-nos mais adequado falar numa consciência popular e num sentimento de identificação com os que possuem padrões de consumo e formas de socialização relativamente semelhantes. Em outras palavras: mais do que identificar-se com uma classe social determinada, os operários se definem como povo pobre, mesclando todas as categorias sociais que se encontram nos escalões inferiores da sociedade urbana. Um sentimento de diferenciação social, mais do que de oposição e de antagonismo, permeia a consciência do grupo estudado (e em grande medida do proletariado brasileiro) separando os que são "pobres" dos que são "ricos". É óbvio que tal tipo de percepção das estruturas sociais tende a dificultar o aparecimento de amplos movimentos reivindicativos organizados em redor da profissão e a favorecer os movimentos políticos e sociais profissionalmente mais heterogêneos que pareçam acelerar a integração das camadas populares na sociedade competitiva. Assim sendo, pode-se prever que, na eventualidade do despertar político desses grupos, sua participação na vida política brasileira deverá efetuar-se sob o signo da problemática da luta contra o subdesenvolvimento, da democratização das oportunidades, ou seja, de suas aspirações de participação nas vantagens da civilização industrial. Em tal caso, se sua mobilização deverá constituir fator de desequilíbrio do status quo, das estruturas tradicionais e, no limite, da própria sociedade competitiva, nem por isso deve implicar a "tomada de consciência de classe" segundo os modelos que o proletariado europeu revelou e as teorias igualitárias teorizaram.

$\mathrm{N}$ os capítulos precedentes procurou-se oferecer uma descrição das principais características dos trabalhadores da Empresa Automobilística. No afã de examinar com pormenor as diversas tabelas e matizar as discrepâncias observadas entre os entrevistados, talvez se tenha tornado a leitura um pouco árida, em particular pela referência constante à comparação entre porcentagens. A forma de exposição adotada, em que as áreas discriminadas foram examinadas separadamente, requer agora uma recapitulação sumária, que ponha em relevo e sistematize as conclusões a que se chegou.

Durante o transcorrer do trabalho fez-se constante referência ao grupo estudado, de um lado, e às características do proletariado brasileiro, de outro. Desejou-se retirar, do estudo de um grupo determinado de trabalhadores, elementos para a compreensão das orientações gerais da classe. Assim sendo, pode-se indagar em que medida seria lícito dizer que os trabalhadores da Empresa Automobilística representam o proletariado brasileiro, tanto mais que se insistiu nas singularidades da empresa, que a distinguem bastante de outras existentes no Brasil. obviamente, as atitudes e orientações do grupo, como se disse inicialmente, decorrem tanto dos traços particulares da empresa quanto das características mais gerais da classe. Portanto, lidou-se com duas ordens de fatores: os que decorrem da situação de trabalho na Empresa Automobilística e os que decorrem da sociedade nacional, especialmente os referentes às características da industrialização e à formação da classe operária brasileira. É desnecessário dizer que as atitudes que advêm dos fatores internos da empresa não podem ser generalizadas, a não ser para os trabalhadores de fábricas semelhantes. Deste modo, está claro que os resultados obtidos na investigação não podem ser estendidos arbitrariamente para o conjunto do proletariado nacional. Mas as atitudes ante a empresa são grandemente influenciadas pelas características gerais do proletariado, pelas suas origens, expectativas e aspirações quanto à sociedade industrial em formação. Tanto seria arbitrário o estudo que pretendesse induzir da análise de um grupo operário particular as características gerais da classe, quanto o que procurasse explicar o seu comportamento em função exclusivamente das determinações internas da empresa ou da situação particular de trabalho e 
emprego. Procurou-se, no transcorrer da análise, evitar ambos os riscos, buscando integrar as duas perspectivas. Mais ainda: procurou-se ter em conta a natureza específica das tarefas que perfaziam os trabalhadores, uma vez que pesquisas já realizadas mostram notável semelhança de conduta entre trabalhadores de países diferentes que realizam um mesmo tipo de trabalho.

Assim, no que diz respeito à representatividade do grupo estudado, pensamos que os resultados alcançados podem ser estendidos, em certa medida, aos demais grupos operários formados no decurso dos últimos anos, em decorrência da implantação, entre nós, de modernas e grandes unidades de produção fabril. Desse ponto de vista, a Empresa Automobilística apresenta-se como um caso típico. Para a explicação do comportamento e das orientações do grupo operário, cumpre retomar as duas perspectivas anteriormente assinaladas. No que tange aos fatores endógenos, isto é, os que decorrem das singularidades da empresa, há alguns elementos ligados à sua implantação que necessitam ser ressaltados. Não se trata de uma empresa industrial que tenha passado por longo processo de crescimento. Junto com o ramo automobilístico, a Empresa Automobilística surgiu rapidamente. Não atravessou as fases clássicas do avanço tecnológico. Instalou-se desde logo como grande empresa, voltada para a produção em massa, seguindo os modelos de organização industrial criados alhures. As empresas automotrizes no Brasil são filiais de organizações sediadas em países desenvolvidos. Para cá transplantaram não só os avanços ocorridos na área da produção e da comercialização do produto, como certos esquemas refinados de relações humanas. A implantação e o crescimento do ramo automotor teve consequências dinamizadoras imediatas no parque industrial paulista. Levou à expansão acelerada da indústria de autopeças e abriu milhares de novos empregos. As cidades que compõem o Grande São Paulo experimentaram rápido surto de crescimento. As novas ofertas de emprego contribuíram para a manutenção das correntes migratórias para São Paulo e para a continuidade do ritmo de urbanização. Em torno da capital formaram-se novos bairros de trabalhadores recentemente chegados do interior, dando origem a uma classe operária com características diferentes da dos antigos bairros operários de São Paulo, quando da instalação das primeiras fábricas de alimentação, bebidas, tecelagem, etc. $\mathrm{O}$ aproveitamento dessa mão de obra, em geral de baixo nível técnico, foi possível graças ao trabalho parcelado e em serie, característico da etapa de industrialização que precede a automação. Assim se explica que a proporção, no grupo estudado, de trabalhadores recém- chegados da agricultura praticamente iguale a de trabalhadores nascidos em São Paulo. A expansão do setor automobilístico e, correlatamente, da indústria de autopeças, acarretou a elevação dos salários, devido à carência de mão de obra especializada e, talvez, à política deliberada das empresas com vistas à sua promoção ante a opinião pública e os órgãos governamentais. Os grupos operários recém-empregados nesse ramo beneficiaram-se, desde o início, de salários bastante superiores aos da média da indústria paulista. Nesse processo, indubitavelmente, as categorias profissionais mais qualificadas foram as mais favorecidas, embora as demais camadas operárias também tivessem sido abrangidas pela elevação salarial e abertura de novos empregos. Repetiu-se aqui, em escala mais restrita e em outras circunstâncias, a mesma situação que permitiu ao proletariado brasileiro a aquisição de certas vantagens trabalhistas sem o recurso a uma forte pressão sobre os grupos patronais ou o Estado e apesar da existência de um excesso de mão de obra no mercado de trabalho nacional.

O desenvolvimento industrial, orientado para a substituição de importações, procurou explorar áreas de consumo já existentes, que passaram a absorver o similar brasileiro em lugar do estrangeiro. Os preços tenderam a fixar-se em torno dos das mercadorias importadas colocadas no mercado interno, isto é, gravadas pelos custos de transporte e pelas barreiras protecionistas e fiscais. Tal mecanismo assegurou ao fabricante nacional altas taxas de lucro, embora sua massa fosse reduzida em decorrência das próprias limitações da demanda interna. A indústria brasileira, por tais razões, foi pouco competitiva, tanto mais que o manufaturado nacional não se destinava a concorrer no mercado internacional. Desse modo, nas condições tecnológicas e sociais em que ganhou impulso a industrialização do país, os esforços para o rebaixamento dos salários não foram tão acentuados quanto os efetuados no início da industrialização Europeia. Em primeiro lugar, porque a acumulação industrial, na etapa atual, se faz precipuamente pela utilização de equipamento mais moderno, visando a economizar mão de obra; em segundo lugar, porque, quer pela necessidade de fixação à indústria de uma mão de obra profissional e socialmente mais preparada, quer por motivos políticos, o próprio Estado chamou a si, adiantando-se às pressões sindicais, a elaboração de leis sociais e trabalhistas e aplicação de um conjunto de medidas destinadas à proteção do operário. $\mathrm{Na}$ ausência de estratos sociais médios, de pequenos proprietários independentes e de camponeses, no sentido clássico da palavra, o mercado consumidor nacional de produtos industriais ficou restrito, em grande parte, ao 
próprio setor moderno da sociedade brasileira, isto é, aos centros urbanos, uma vez que os grupos rurais com forte poder aquisitivo constituem ínfima minoria e as massas agrícolas estão praticamente fora do mercado consumidor de produtos industrializados. A compressão dos salários reais das camadas assalariadas sempre ameaça reduzir o já restrito mercado interno. Assim se explica que, mesmo tendo-se em conta a existência de um vasto excedente de mão de obra, o proletariado brasileiro tenha logrado garantias sociais praticamente sem contar com poderosas organizações sindicais e sem grandes lutas. Ocorre que o extremo atraso das populações das áreas tradicionais revela-se uma forma de proteção para os grupos operários já constituídos e inseridos no sistema industrial.

O proletariado brasileiro é formado, nos seus estratos superiores, por migrantes ou filhos de estrangeiros. Os setores semiqualificados e braçais, na sua maioria, são retirados do setor primário da economia. No primeiro caso, a própria carência de trabalhadores qualificados, ou seja, a procura maior do que a oferta contribui para a defesa dos salários reais desses grupos. No segundo caso, a oferta do fator trabalho é abundante enquanto os salários industriais mantiverem-se superiores aos da agricultura. Mas o atraso cultural das populações rurais, o analfabetismo, a falta de qualquer qualificação, a inexperiência no que tange aos múltiplos requisitos para a vivência no meio urbano dificultam seu aproveitamento como mão de obra industrial. Insistimos que não se trata apenas de uma questão de adequação técnica, pois o trabalho parcelado implica a desqualificação profissional sendo o adestramento para a realização das tarefas bastante rápido. Trata-se, em grande parte, de desqualificação social e educacional em geral. Do ângulo do aproveitamento desse exército industrial de reserva, cumpre ver que as indústrias modernas necessitam, ao menos, de trabalhadores alfabetizados, de indivíduos capazes de se ajustar com razoável rapidez à organização interna da empresa. O exemplo da indústria automobilística ilustra tipicamente essa situação. Os salários, nesse ramo, não se teriam mantido muito acima da media vigente no parque industrial paulista se a oferta de trabalhadores dotados de certa qualificação profissional e social fosse elevada. A própria utilização de trabalhadores chegados há pouco da agricultura não ocorreria se não houvesse premência de mão de obra. Deste modo, se a abundância do fator trabalho e a existência de ampla reserva de mão de obra barata diminuem a capacidade de barganha da classe operária, o baixíssimo nível de qualificação profissional e educacional da população rural dificulta uma compressão excessiva dos salários já baixos em comparação com os vigentes em países desenvolvidos. Nessas circunstâncias, as camadas empresariais conservam amplamente o controle dos salários e a capacidade reivindicativa dos sindicatos é fortemente reduzida. Os salários fixam-se segundo as necessidades de atração de mão de obra para a indústria, isto e, segundo as conveniências dos grupos empresariais nos diversos ramos fabris. Dado que os níveis de consumo das camadas inferiores da população brasileira, particularmente das populações rurais, são extremamente baixos, é evidente que os salários industriais não tendem, salvo para uma ou outra categoria profissional, a elevar-se consideravelmente. Na hipótese de uma agressividade reivindicativa acentuada dos estratos operários já integrados no setor secundário, o enorme estoque de mão de obra continua sempre à disposição para ser, em caso de necessidade, rapidamente utilizado. Os salários da massa operária brasileira são, deste modo, diretamente condicionados pela ação de dois elementos: de um lado, a necessidade de mão de obra que tende a elevá-los independentemente das exigências sindicais; de outro lado, a presença maciça das migrações rurais-urbanas que tende a rebaixá-los. Em ambos os casos, a iniciativa está sempre nas mãos do setor empresarial, tanto mais que a remuneração na indústria tem sido sempre suficientemente superior à da agricultura para proporcionar ao migrante a valorização do emprego industrial, ao qual se aliam as garantias outorgadas pela legislação trabalhista. Assim, as grandes empresas estrangeiras instaladas no Brasil, se porventura afligidas pela instabilidade política, em compensação têm que lidar com um proletariado industrial desorganizado e incomparavelmente menos exigente do que o dos países altamente industrializados.

Os grupos operários que se formam assim rapidamente, quando da instalação de grandes empresas modernas, apresentam feições bastante singulares. Normalmente, faltam-lhes uma tradição operária comum e uma experiência maior no que diz respeito à utilização das instituições existentes na sociedade industrial. Dado que os estabelecimentos estrangeiros normalmente têm condições de oferecer melhores salários e procuram, se mais não for por motivos políticos, obedecer estritamente a legislação social em vigor, a obtenção de emprego nessas companhias é altamente desejada. Para uma população pobre, carente de outras alternativas profissionais e outros meios de subsistência, o apego ao emprego tende a ser muito forte. Esse é concebido em termos de um projeto de melhoria de vida ou de 
ascensão social. No entanto, as possibilidades de ascensão na hierarquia das empresas, mesmo quando estas atravessam uma fase de expansão, como a Empresa Automobilística no momento em que fizemos a pesquisa, são restritas. A grande massa de trabalhadores entra na companhia como operário e sai nessa mesma condição. A monotonia e a falta de atrativo das tarefas repetitivas induzem a um desinteresse pelo trabalho. As categorias operárias semiqualificadas e braçais tendem, destarte, a manifestar uma preocupação e uma sensibilidade muito aguçadas pelo salário, tanto mais que efetivamente ocupam os níveis inferiores da escala de remuneração. Em contrapartida, os aspectos propriamente socioprofissionais do trabalho e da condição operária ocupam segundo plano, ao contrário do que tende a ocorrer com os trabalhadores mais qualificados e dotados de certa autonomia profissional. O trabalho operário é encarado negativamente e as aspirações de passar a empregado de escritório ou de trabalhar por conta própria são sempre muito vigorosas. A rejeição da condição operária, ao mesmo tempo em que dificulta a integração na classe, impede a formação de uma visão do mundo "obreirista" e a participação nas atividades das associações operárias. Do mesmo modo, os apelos ideológicos classistas tem pequeno efeito sobre esses grupos operários. Para os efetivos de migração recente, a empresa, o sindicato e a sociedade industrial são concebidos instrumentalmente, como meios a serem utilizados, sem com eles se identificarem e comprometerem emocional ou moralmente. No que tange ao sindicato, este é avaliado em termos das vantagens pessoais que pode oferecer, sem que o trabalhador entenda que a força da instituição depende de sua participação e esforços.

O bloqueio das possibilidades de ascensão, para um grupo motivado justamente por essa aspiração, conduz a acentuado pessimismo. $\mathrm{O}$ desencanto dos grupos operários de formação recente é tanto mais acentuado quanto a sociedade, nas condições de subdesenvolvimento, não tem, efetivamente, possibilidades de oferecer outras formas de compensação externas ao meio fabril: alto padrão de consumo, participação intensa nas modernas formas de lazer e recreação, etc. No caso dos operários estudados, o setor mais qualificado, gozando de salários bastante elevados em cotejo com a média salarial paulista, tinha condições de lograr outras compensações na esfera do consumo e de alimentar esperanças de ascender socialmente, graças às suas aptidões profissionais. O setor de baixa qualificação, praticamente, já tinha deixado de lado a crença nas possibilidades ulteriores de ascensão social. Os trabalhadores recém-chegados de áreas tradicionais eram os mais pessimistas. A desilusão e a frustração quanto à situação presente, contudo, não contribuem para o fortalecimento do sindicato, da coesão interna do grupo e para a emergência de atitudes hostis à empresa uma vez que essa é considerada, precisamente, como a instituição que permitirá a melhora de vida do grupo, sendo a situação presente considerada mais satisfatória do que a situação passada. $\mathrm{O}$ pessimismo e o descontentamento não têm suas raízes na empresa, embora o trabalhador encare criticamente a condição operária e a ordem político-social global. Se há aceitação da empresa e rejeição da condição operária, o descontentamento não pode servir de base para a crítica classista da ordem social. Se a visão da sociedade industrial não se estrutura a partir de uma posição de classe, as forças sociais adversas não são localizadas na esfera da produção. A percepção das ordenações sociais elabora-se a partir das diferenças observadas nos níveis de consumo, de poder e de educação, mas não das posições diferenciadas ocupadas pelos agentes e grupos sociais no sistema produtivo. Para que ocorresse o contrário, seria necessário que o avanço da industrialização brasileira não tivesse ficado restrito a pequenas áreas do país. Em outras palavras: teria sido preciso que o industrialismo tivesse impregnado mais profundamente os valores e a conduta dos agentes e instituições sociais. Porém, a industrialização, na sociedade capitalista de massas, age no sentido de corroer os elementos que convergiam no sentido de propiciar comportamentos revolucionários e a emergência da consciência de classe entre o proletariado. Se tais condutas e formas de consciência não encontram clima propício nas sociedades fortemente influenciadas por ideais e valores tradicionais, tampouco o encontram nas sociedades modernas na sua fase "afluente". De um lado, no plano da sociedade, as possibilidades ampliadas de consumo, a ação dos meios de comunicação de massas, tendem a dissolver os elementos que contribuíam para a configuração das classes enquanto vastos aglomerados inclusivos, coesos internamente, relativamente delimitados e hostis entre si; de outro lado, no plano da empresa, a moderna tecnologia e organização do trabalho industrial tendem a enfraquecer os fatores que favoreciam a cristalização de uma cons. ciência de produtor e de explorado entre as camadas operárias. A consciência de classe, observa Touraine, encontrou campo para seu pleno florescimento quando do encontro do sistema profissional de trabalho com a grande organização industrial. Que tipo de orientação ideológica e de consciência operária poder-se-ia encontrar num proletariado que se forma diretamente sob o moderno sistema de trabalho industrial inserido num meio social que contém, 
concomitantemente, elementos de sociedades afluentes e de sociedades tradicionais? Numa fase avançada da expansão industrial, as sociedades ricas podem oferecer ao operário "compensações" na esfera do consumo. As instituições sindicais e políticas lhe dão meios de pressão e reivindicação, cujas possibilidades de atendimento permitem a existência de um reformismo das classes operárias (Europa Ocidental), ou de uma adesão aos valores básicos do sistema (EUA). No caso de áreas subdesenvolvidas, com regiões fortemente contrastantes, como no Brasil, o descontentamento relativo aos problemas derivados da situação de trabalho tendem a passar a segundo plano. As camadas operárias, em decorrência da escassa industrialização, são demasiadamente débeis para uma pressão em larga escala sobre as grandes empresas e o Estado. Além disso, trata-se de grupos sociais recém-formados que dão os primeiros passos no ambiente industrial e urbano. Dispõem de fracos meios de intervenção sistemática na vida política nacional. Malgrado a valorização do emprego industrial, a adesão dessas massas semi-integradas à ordem social é pequena. Em primeiro lugar, porque não se lhes abriram, realmente, amplas oportunidades de participação nas vantagens da civilização industrial, enquanto novas aspirações de consumo foram despertadas. Em segundo lugar, porque não assimilaram inteiramente os valores e modos de conduta do meio urbano. Seus estratos superiores têm condições de manter ou mesmo ampliar sua participação nas vantagens da ordem urbano-industrial, mediante pressão coletiva, valendo-se de sua situação privilegiada para a barganha no mercado de trabalho, o que pode propiciar o surgimento de um reformismo operário entre esses setores. As camadas inferiores do proletariado, contudo, não podendo valer-se desses recursos, sentem-se inteiramente desamparadas. A rejeição do status quo político-social, na ausência de uma consciência profissional e de uma identificação com a condição operária, dificilmente poderia ultrapassar o populismo: através do apoio a líderes das camadas superiores expressam seu descontentamento e frustração ante uma sociedade de consumo que não tem condições de atender as expectativas por ela mesma despertada. Se na raiz do descontentamento dessas massas trabalhadoras estivessem os problemas do mundo do trabalho e da fábrica, da rejeição do sistema capitalista de produção, sua expressão ideológica não poderia ser de tipo populista.

O populismo, por suas características, exprime o despertar de massas que há pouco adquiriram o direito de participação política e que reivindicam uma participação maior nas vantagens da civilização contemporânea. Os movimentos populistas organizam-se em torno de exigências colocadas na esfera do consumo. Há, nesse tipo de mobilização política, um sentimento difuso de antagonismo social, fundado não na ideia da oposição e conflito entre classes, mas na percepção de desníveis sociais, de riqueza e de autoridade. O populismo separa e distingue, de um lado, o povo e os pobres e, de outro, os ricos e os que mandam. Seu traço marcante é a inexistência de uma organização capaz de arregimentar, de modo permanente, as camadas inferiores. Reside aqui uma das debilidades mais pronunciadas dos grupos operários e, de modo geral, dos estratos inferiores da sociedade brasileira. A debilidade organizatória das camadas operárias emergentes constitui, para o status quo, ao mesmo tempo uma garantia e um risco. Se, de um lado, enfraquece o poder reivindicativo das camadas assalariadas, de outro lado, faz com que sua, intervenção ameace efetuar-se fora de qualquer controle, o que não ocorreria se a mobilização pudesse se dar através de instituições legitimadas pela ordem social. Mas essa não atingiu um grau de racionalidade e de confiança em si mesma capaz de conduzir à institucionalização do conflito e à participação dos estratos populares e operários nas decisões do Poder. Assim, no atual contexto político e social, a participação dos setores inferiores só tem podido ocorrer quando esses se sentem relativamente apoiados por segmentos das classes superiores, estimulados por uma cobertura que venha de cima. $\mathrm{O}$ apoio às lideranças populistas revela, ao mesmo tempo, a heteronomia das camadas operárias, o desejo de proteção e a rejeição das atuais estruturas de dominação. A conjugação desses três fatores redunda na preferência por regimes autoritários que atendam o trabalhador em suas reivindicações, coíbam a liberdade e o poder de mando dos ricos, dos políticos e dos comerciantes. Quanto mais pronunciada a falta de qualificação profissional e educacional das camadas inferiores e quanto mais carentes de meios para a intervenção independente na vida política nacional, tanto maior a disposição para apoiar movimentos radicais e regimes autoritários que lhes pareçam proporcionar uma garantia mais eficaz contra os poderosos e os ricos. A opção por regimes democráticos só se poderia dar se esses grupos operários tivessem meios de utilizar as instituições da ordem democrática para o logro de suas aspirações básicas e se a ordem competitiva democrática garantisse realmente o direito de participação de tais setores. Na ausência dessas condições, o regime de democracia representativa lhes parece privilegiar amplamente os grupos de renda superior, estrategicamente situados e capazes de manipular em seu proveito os organismos de Poder. 
Pelo que indica o estudo dos trabalhadores da Empresa Automobilística, uma profunda ambiguidade parece marcar os grupos operários que se formam nas condições do moderno capitalismo industrial em regiões insuficientemente desenvolvidas. Essa ambiguidade repousa na extrema valorização do emprego fabril, conjugada à recusa da condição operária, decorrente das aspirações de melhoria de vida e de ascensão social apenas parcialmente atingidas; no desejo de maior participação nos benefícios materiais e sociais da civilização industrial associado à despreocupação com as questões referentes ao controle das decisões, aos níveis da empresa e da sociedade global; no desencanto e na frustração com relação ao status quo vinculados à valorização e aceitação da ordem capitalista, na medida em que ela significa progresso e desenvolvimento em comparação com a ordem pré-industrial. Esses grupos operários escaparam recentemente das formas tradicionais de controle político e estão fazendo suas primeiras experiências como categorias sociais emergentes em outro contexto socioeconômico. Até o presente, obtiveram oportunidades de emprego e de melhoria de seu padrão de consumo sem que tivessem de realizar esforço maior de pressão e mobilização sistemática. Para predizer com segurança suas orientações futuras seria preciso poder diagnosticar as possibilidades de expansão e consolidação da sociedade industrial no Brasil. No estado atual das pesquisas sociológicas sobre a industrialização e sobre o tipo de sociedade que se está formando em nosso país é impossível fazer qualquer vaticínio seguro. De modo geral, as ambiguidades da estrutura da situação de classes e a inconsistência das formas de consciência social impedem que o futuro seja idealizado socialmente pelas diversas camadas sociais em presença. Nem os grupos empresariais são capazes de se definir inteiramente pelo tipo de ordem social competitivo (com todas suas implicações institucionais, políticas e sociais) nem os operários industriais fazem qualquer espécie de opção decisiva que permita vislumbrar em que sentido deverão se orientar nos próximos anos. Contudo, é possível supor, no tocante aos grupos operários, que sua inserção na economia de mercado e de consumo contribuirá para fazê-los mais exigentes quanto à sua situação de consumidores. Em tal caso, cumpriria saber não somente das orientações ideológicas que poderiam predominar como também dos meios e instrumentos de participação sociopolítica de que disporiam. A natureza do processo de industrialização por que passa atualmente o país não propicia forte aumento dos contingentes operários. No último decênio, a proporção de trabalhadores industriais chegou mesmo a diminuir em comparação com outros setores da população ativa, principalmente com relação à do setor de serviços. Pode-se prever que, mesmo na hipótese de uma aceleração dos investimentos industriais, o crescimento quantitativo da classe operária será muito pequeno, pois o tipo de tecnologia utilizado, segundo modelos dos países desenvolvidos, repousa no emprego intensivo de capital e na poupança de mão de obra. O peso numérico do proletariado industrial no conjunto da população será menor do que teve nos países de antiga industrialização. Embora situado estrategicamente no setor mais dinâmico da economia brasileira e concentrado nos grandes centros urbanos, sua capacidade de barganha e pressão será sempre enfraquecida pela presença dos grandes contingentes populacionais que criam um excesso de oferta de trabalho e diante dos quais o proletariado das modernas empresas constitui um setor privilegiado.

Não seria preciso insistir novamente que o grupo estudado, e as camadas operárias de um modo geral, encontram-se em nível extremamente baixo de organização autônoma e de definição de seu papel na sociedade nacional. Não há porque julgar que tal quadro deva permanecer inalterado. Porém, as formas e os conteúdos das transformações que porventura venham a ocorrer são atualmente impossíveis de prognosticar. Seria fácil (e a nosso ver errôneo) partir da ideia de uma "evolução" linear da classe operária que partisse de um mínimo de organização, de capacidade de intervenção e de consciência de seus interesses para um máximo de atuação e politização que, no final, implicaria na rejeição da ordem capitalista. As sociedades desenvolvidas do Ocidente revelaram insuspeitada capacidade de absorção dos conflitos industriais e de flexibilidade institucional de modo a arrefecer o ímpeto do protesto operário. A questão básica é saber se a ordem capitalista no Terceiro Mundo apresenta as mesmas possibilidades de institucionalização do conflito, de integração não só dos trabalhadores industriais como também, e principalmente, dos grandes contingentes populacionais marginalizados pelo nosso processo de crescimento econômico dependente. Pensamos, no que tange às camadas operárias, que um possível aumento de sua participação na vida política e social do país terá como ponto de partida suas aspirações a uma maior e efetiva participação nos benefícios da civilização industrial: suas orientações futuras dependerão amplamente da capacidade do sistema de responder a tais aspirações. 


\section{A PESQUISA:}

\section{PROCEDIMENTO METODOLÓGICO}

A presente pesquisa foi realizada durante o período que se estendeu de março a novembro de 1963. Durante o primeiro semestre limitamo-nos a estagiar nas diversas secções da companhia e a estudar a organização da empresa, sua política de relações humanas, a organização da produção, etc. Neste período, foi-nos possível trabalhar durante uma semana como operário (operador) em uma das fábricas da empresa. O semestre foi aproveitado, igualmente, para conversas informais com os trabalhadores, em suas residências e na própria empresa, no restaurante e nos períodos das pausas para descanso. Demais, efetuamos dez entrevistas "abertas" que serviram de guia para a elaboração do questionário. Procuramos sempre esclarecer aos operários de que éramos um professor da Secção de Ciências Sociais da Universidade de São Paulo interessado em conhecer a opinião dos entrevistados sobre diversos assuntos. Insistimos sempre de que não tínhamos nenhum relacionamento empregatício ou de outra natureza com a empresa. Sem uma exceção, os trabalhadores mostraram-se sempre acessíveis e desejosos de colaborar. A Empresa Automobilística, por sua vez, não opôs nenhuma restrição ao nosso trabalho e sempre se dispôs a pôr à nossa disposição dados e informações sobre seu funcionamento interno relacionado aos objetivos da pesquisa. Solicitou apenas que o nome verdadeiro da empresa não fosse mencionado.

A aplicação dos questionários foi feita por estudantes do Curso de Ciências Sociais da Faculdade de Filosofia, Ciências e Letras da Universidade de São Paulo, na residência dos entrevistados. As entrevistas tiveram a duração média de duas horas e meia. No final deste volume, em apêndice, encontra-se cópia do questionário aplicado.

A seleção da amostra foi feita por sorteio probabilístico de uma relação de operários que as companhias enviam à Delegacia Regional do Trabalho. Foram excluídos da amostra o pessoal de escritório e de administração, o pessoal técnico, bem como os trabalhadores encarregados de limpeza, segurança, restaurante, transporte, etc. Assim, o grupo selecionado consta apenas de trabalhadores diretamente ligados à produção, não importando o setor (montagem, estamparia, usinagem, etc.).
No total, foram entrevistados 86 indivíduos. Desses, 62 constituem o que chamamos de "operários comuns", e que nas tabelas aparecem sob a rubrica de operários. A grande maioria, como seria de se esperar, dado o tipo da empresa, é constituída de trabalhadores semiqualificados, principalmente de montadores e operadores. ${ }^{1}$ São operários, como sintetiza Ítalo Bolonha, que executam "operações simples e repetidas, exigindo, sobretudo atenção e coordenação motora. Trabalho sujeito a automatismo. Escolaridade primária. Treinamento no próprio local de trabalho, em tempo relativamente curto (100 a 150 horas) mediante adestramento de poucas operações e explicações tecnológicas elementares". ${ }^{2}$

$\mathrm{O}$ grupo de trabalhadores qualificados é representado pelos ferramenteiros (18 indivíduos) e "líderes" (6 indivíduos). Os ferramenteiros enquadram-se integralmente na conceituação de operário qualificado que oferece Ítalo Bolonha, isto é, trabalhadores que executam "todas as operações do ofício, possuindo aptidões psicomotoras e mentais, conhecimentos tecnológicos da especialidade, realizando trabalhos variados, não sujeitos a automatismo e cuja formação profissional requer uma aprendizagem variando em torno de 4 mil horas". Na Empresa Automobilística, esta categoria profissional é nitidamente diferenciada dos operários comuns, semiqualificados, não só pelos salários consideravelmente mais elevados, como também pelos status que ocupam. O símbolo externo e visível desta

1 Foi esta a composição da amostra, de acordo com a categoria profissional dos entrevistados; 13 montadores; 13 operadores; 6 mecânicos; 4 soldadores; 4 tapeceiros; 4 funileiros; 4 ponteadores; 3 conferentes; 3 lixadores; 3 prensistas; 2 pintores; 1 supervisor de peças; 1 retificador da produção; 1 costureira.

2 Ítalo BOLONHA, "Demanda de mão de obra especializada no atual surto industrial brasileiro", in: Educação Técnica e Industrialização, São Paulo, Centro $e$ Federação das Indústrias do Estado de São Paulo, 1964. A conceituação da qualificação do trabalho oferece algumas dificuldades de natureza teórica que não pretendemos discutir aqui. No caso concreto de algumas profissões, a classificação pode prestar-se a controvérsias. Assim, os soldadores, de um modo geral, poderiam ser definidos como qualificados, como aponta Ítalo Bolonha. Na amostra, foi impossível determinar com grande precisão, em alguns casos, em que categoria deveria ser incluído o entrevistado. É possível que trabalhadores melhor dotados profissionalmente se encontrem realizando tarefas repetitivas e parceladas, atraídos pelos altos salários pagos na indústria automobilística. Demais, dentro de uma mesma categoria profissional, é possível encontrar gradações que infelizmente não nos foi possível matizar. Os salários recebidos pelos entrevistados, nestas condições, constituíram uma forma rudimentar de controle. Para uma apreciação mais ampla dos problemas relacionados à qualificação do trabalho, Cf. Pierre NAVILLE, Essai sur la Qualification du Trauail, Paris, Marcel Rivière, 1956 
separação é o uso de aventais de serviço em lugar do "macacão" habitual vestido pelos menos qualificados. Os "líderes" não chegam a constituir propriamente uma categoria profissional. São operários que pelos conhecimentos profissionais mais elevados servem de auxiliares técnicos dos mestres e contramestres mas sem gozarem da mesma posição de autoridade. Algumas vezes ensinam aos novos operários as suas funções, preparam-lhes as máquinas e, outras vezes ainda, os substituem quando de sua falta; cabem aos líderes tarefas variadas, servindo amiúde como uma espécie de utilityman. Seus salários, na amostra, situaram-se numa escala intermediária entre os dos operários semiqualificados e os dos ferramenteiros. Examinando os seus níveis de escolaridade e de formação profissional, e na impossibilidade de uma análise isolada deste grupo, preferimos incluí-los, em nossas tabelas, entre os ferramenteiros.

Para a interpretação dos resultados, além da separação entre ferramenteiros e "operários comuns", tabulamos separadamente os indivíduos que já tinham trabalhado na agricultura (Agric. nas tabelas) e os que não tinham tido nenhuma experiência de trabalho na lavoura (Urb. nas tabelas). Nesta classificação, não se levou em conta o período de tempo que medeava $\mathrm{o}$ abandono da agricultura e a entrada na indústria. Na maioria das tabelas, as diferenças observadas nas atitudes desses grupos foram insignificantes. Além disso, encontrou-se entre os entrevistados que nunca tinham trabalhado na agricultura, isto é, entre os Urb., uma fração importante originária de pequenas cidades do interior, onde exercia as mais variadas profissões, inclusive a de operário industrial. Objetivando poder captar mais firmemente a possível influência dos hábitos e valores urbanos em contraposição aos do meio tradicional no comportamento dos operários, estabelecemos outros dois grupos. Separamos, de um lado, os trabalhadores nascidos e educados em São Paulo ou em outro grande centro urbano, como o Rio de Janeiro, ou seja, indivíduos que nunca tiveram experiência de trabalho na agricultura, e que, de modo algum, poderiam ser considerados migrantes de áreas rurais ou tradicionais. Nessa situação foram encontrados 22 entrevistados (26\% do total da amostra). Embora apenas uma minoria provenha de famílias de operários industriais propriamente ditos, quase todos (com exceção de seis casos) são filhos de trabalhadores manuais (marceneiros, pintores, motorneiros, carroceiros, pedreiros, etc.) Nas tabelas, esse grupo aparece sob a rubrica de Mod. No outro polo, agrupamos os entrevistados recentemente chegados de áreas tradicionais e da agricultura (Trad., nas tabelas). Para a inclusão do operário neste grupo, resolvemos considerar 1953 como o ano limite, excluindo todos os migrantes que tinham chegado a São Paulo antes desta data. Assim sendo, todos os respondentes deste grupo têm um período de vivência em São Paulo (ou no Grande São Paulo) não superior a dez anos, contados quando da aplicação do questionário. Encontramos 20 trabalhadores nessa situação, perfazendo $23 \%$ do total da amostra. Note-se, entre os Trad., que exatamente a metade chegou a São Paulo depois de 1960. Trata-se, portanto, de migrantes que estão dando seus primeiros passos no meio urbano-industrial. Na seleção dos indivíduos que integraram esta sub amostra, procedemos segundo dois critérios: I) quando se tratava de trabalhadores provenientes do interior do Nordeste e Norte do país não levamos em consideração se o entrevistado tinha ou não trabalhado na lavoura; II) quando se tratava de trabalhadores originários do interior do Estado de São Paulo, selecionamos apenas os que vinham da lavoura, dada a existência de cidades relativamente importantes neste Estado, em que os padrões urbanos e modernos encontram-se razoavelmente difundidos. No total, tivemos entre os Trad. 75\% de ex-lavradores migrados recentemente para São Paulo. Os demais, originários do interior do Piauí, Alagoas, Ceará, Pernambuco, etc., eram trabalhadores braçais, de escassa qualificação; aqui houve apenas uma exceção: a de um entrevistado que trabalhava por conta própria no setor de comércio.

O empenho em construir grupos tão diferenciados quanto possível no que diz respeito ao ambiente socioprofissional de proveniência diminuiu bastante a subamostra dos Mod. e Trad., reduzindo a utilidade do uso de correlações estatísticas. Deste prisma, os dados apresentados em porcentagem devem ser tomados mais como indicações. Porém, o procedimento adotado ofereceu a vantagem de poder pôr em relevo, de modo mais acentuado, o contraste entre os operários recém-chegados do mundo rural (Trad.) e aqueles de origem urbana (Mod.). O leitor notará, nas diversas tabelas, como as diferenças nas orientações e atitudes de ambos os grupos configuram-se de modo mais ou menos nítido e coerente para a interpretação. Naturalmente, teria sido preferível poder lidar com amostras maiores, possibilitando amplamente a utilização dos recursos estatísticos. No entanto, as reduzidas dimensões da sub amostra, resultado da opção por um trabalho com grupos internamente homogêneos e diferenciados entre si, permitiu o exame minucioso de cada questionário individual. Procurou-se, pois, compensar qualitativamente o que se perdia quantitativamente. 
No capítulo III, referente ao trabalhador e o sindicato, apresentamos os resultados das tabulações distinguindo as respostas dos operários sindicalizados e não sindicalizados. Todavia, em quase todo o transcorrer da análise omitimos as tabelas relativas a estes dois grupos. A comparação das respostas mostrou que o atributo "sindicalização", na imensa maioria das vezes, nenhuma influência exercia nas atitudes dos entrevistados. Nestas condições, para não sobrecarregar ainda mais o leitor com novos algarismos, preferimos omitir, nas tabelas, os resultados relativos aos sindicalizados e não sindicalizados.

Uma última observação deve ser feita: o presente estudo pretendia abranger a análise da organização sindical à qual se filiam os trabalhadores da Empresa Automobilística. Os eventos político-militares de março de 1964, infelizmente, prejudicaram esta parte da pesquisa. A diretoria do sindicato, em exercício quando da aplicação do questionário, foi afastada pelas autoridades do Ministério do Trabalho e o sindicato foi colocado sob intervenção. Nestas condições, optamos por abandonar parte do projeto inicial, restringindo-nos apenas aos trabalhadores da Empresa Automobilística, cujos dados já tinham sido coletados, e deixando de lado a parte referente ao sindicato.

\section{QUESTIONÁRIO APLICADO}

1. Onde o Sr. nasceu?

$$
\begin{aligned}
& \text { ( ) - Capital } \\
& \text { ( )-Estado de São Paulo } \\
& \text { ( )- Outro Estado-Qual? } \\
& \text { ( )- Outro país - Qual? }
\end{aligned}
$$

2. (se nasceu em outra cidade ou estado ou pais)

- Por que veio o Sr. Para São Paulo?

\subsection{Quando veio para São Paulo? (data)}

3. Nacionalidade do pai:

Nacionalidade da mãe:

4. Qual a profissão do pai? (anotar os principais empregos do pai)

5. Antes de trabalhar na E. A., o Sr. (último emprego antes da E. A.)
( ) Não teve nenhum emprego
( ) Trabalhava por conta própria
( ) Trabalhava como operário
( ) Trabalhava com a família
( ) Trabalhava como empregado (não era operário)
( ) Outros

5.1. (Se b, c, d, e, f) - O que o Sr. fazia?

6. E antes desse emprego? (penúltimo emprego antes da E. A.)
( ) Não teve nenhum emprego
( ) Trabalha
( ) Trabalhava como operário
( ) Trabalhava com a família
( ) Trabalhava como empregado
( ) Outros

7. O Sr. trabalhou alguma vez na roça?
a) ( ) $\mathrm{Sim}$
b) ( ) Não 
8. O Sr. trabalhou alguma vez por conta própria?
a) ( ) $\mathrm{Sim}$
b) ( ) Não

8.1. (Se sim) - Em que trabalhou?

8.2. (Se $\operatorname{sim})$ - Por que desistiu?

9. Há quanto tempo o Sr. trabalha na E. A.?

10. Por que saiu do último emprego?

11. Por que o Sr. foi trabalhar na E. A.? (verificar sobretudo as expectativas do e. em relação ao novo emprego e os motivos precisos por que foi trabalhar na E. A.)

12. Quando o Sr. começou a trabalhar na E. A. o Sr. fazia o mesmo serviço que faz atualmente?

\section{( ) $\mathrm{Sim}$}

( ) Não

13. (Se não) - Qual o cargo e a função que o Sr. exercia antes?

14. Qual o cargo e a função que o Sr. exerce atualmente na E. A.?

15. Como aprendeu a profissão atual?

( ) Aprendeu na E.A

( ) Aprendeu no SENAI ou outras escolas

( ) Aprendeu na prática em empregos anteriores

( ) Outros

16. Durante o período em que o Sr. trabalhou na E. A., o Sr. teve alguma promoção?

$$
\text { a) ( ) - Sim - Quais? b) ( ) - Não }
$$

17. Que critérios os operários acham que a firma utiliza para promover os empregados?

18. Qual o posto mais alto que o Sr. acha que pode alcançar na E. A.?

19. Quanto ganha uma pessoa que exerce as funções que o Sr. exerce?
20. Quando o Sr. começou a trabalhar na E. A., o Sr. teve:

( ) Muita dificuldade em se adaptar ao novo emprego

( ) Pouca dificuldade com os regulamentos

( )Nenhuma dificuldade em se adaptar ao novo emprego

( ) Não sabe

( ) Sem resposta

21. (Se teve dificuldade) - Dificuldade com o que?

( ) Dificuldade com a tarefa em si

( ) Dificuldade com os regulamentos

( ) Dificuldade em se adaptar aos novos colegas

( ) Não sabe

( ) Sem resposta

( ) Outras disponibilidades. Quais?

22. De um modo geral, o Sr. acha que a E. A. paga:
( ) Melhor que as outras indústrias
( ) Igual as outras indústrias
( ) Pior que as outras indústrias
( )Depende - Do que?
( ) Não sabe
( ) Sem resposta

23. De um modo geral o Sr. acha que a E. A. paga:
( ) Melhor que as outras indústrias automobilísticas
( ) Igual as outras indústrias automobilísticas
( ) Pior que as outras indústrias automobilísticas
( ) Depende - Do quê?
( ) Não sabe
( ) Sem resposta

24. O Sr. pretende trabalhar sempre na E. A.?
( ) $\mathrm{Sim}$
( ) Não
( ) Depende - Do quê?
( ) Não sabe
( ) Sem resposta

25. Em que o Sr. pretende trabalhar no futuro? 
26. Se por acaso o Sr. fosse despedido da E. A., o Sr. acha que encontraria outro emprego semelhante?
( ) Com muita facilidade
( ) Com alguma facilidade
( ) Com alguma dificuldade
( ) Com muita dificuldade
( ) Não sabe
( ) Sem resposta

26.1. Por que?

27. Ainda, se por acaso o Sr. saísse da empresa, que tipo de trabalho o Sr. iria procurar em primeiro lugar?

( ) Tentaria trabalhar por conta própria

( ) Tentaria arrumar emprego em outra ind. Autom.

( ) Tentaria arrumar emprego em qualquer outra ind. Autom.

( ) Outros

( ) Não sabe

( ) Sem resposta

27.1. Por que?

28. Se o Sr. pudesse ganhar em outra empresa $20 \%$ a mais do que o $\mathrm{Sr}$. ganha na E. A., o Sr. mudaria de emprego?
( ) $\operatorname{Sim}$
( ) Não
( ) Depende
( ) Não sabe
( ) Sem resposta

28.1. Por que?

29. Na opinião do Sr., quais as principais vantagens e desvantagens que a E. A. apresenta em relação às outras indústrias?
a) Vantagens
b) Desvantagens

30. O que desagrada o Sr. no trabalho que faz na E. A.?
31. Os empregados da E. A. acham que a Cia. os trata bem?

( ) Acham

( ) Não acham

( ) Depende

( ) Não sabe

( ) Sem resposta

31.1. Por que?

32. De um modo geral, os empregados da E. A. pensam que a empresa paga a eles o salário que eles merecem?
( ) Acham
( ) Não acham
( ) Depende
( ) Não sabe
( ) Sem resposta

33. Se o Sr. pudesse fazer qualquer melhoria na E. A. em beneficio dos operários, quais as principais modificações que o Sr. faria?

34. Numa Cia. qualquer, dos itens abaixo, quais os três que o $\mathrm{Sr}$. considera mais importantes?
( ) Fornecer boa alimentação
( ) Pagar altos salários
( ) Cooperativa de consumo para os empregados
( ) Condução própria
( ) Bom ambiente de trabalho
( ) Chefes justos, Honestos
( ) Dar possibilidades para o empregado subir na Cia.
( ) Treinamento, aperfeiçoamento técnico

35. E desses itens, no caso da E. A., quais os que os operários acham que "existem mesmo"?

( ) Fornecer boa alimentação

( ) Pagar salários mais elevados que outras ind.

( ) Cooperativa de consumo para os empregados

( ) Condução própria

( ) Bom ambiente de trabalho

( ) Chefes juntos, honestos

( ) Dar possibilidades para o empregado subir na Cia.

( ) Treinamento, aperfeiçoamento técnico 
36. O Sr. já ouviu falar da Comissão de Relações do Trabalho?
a) ( ) $\mathrm{Sim}$
b) ( ) Não
c) ( ) Sem resposta

37. (Se sim) - Os empregados acham que a Comissão de Relações do Trabalho trouxe vantagens para eles?

38. Que profissão o Sr. desejaria para seu filho?

39. O Sr. gostaria de passar a trabalhar em escritório?

39.1. Por quê?

40. Na opinião do Sr., o que é um operário?

41. Quais as principais diferenças entre um operário e um patrão?

42. Há muita gente sindicalizada na empresa em que o Sr. trabalha? Por que há pouca gente sindicalizada? Por que há muita? (na fábrica e na secção)

43. O Sr. é sócio de algum sindicato?
( ) Não
( ) Sim. De qual?
( ) Sem resposta.

44. (Se sim)- O Sr. frequenta o sindicato, comparece às assembleias?

45. Quais as vantagens que os sindicatos oferecem aos trabalhadores? E ao Sr. particularmente?

46. Quais o Sr. acha que devem ser as principais funções do sindicato?

47. E destas funções, quais as três que o Sr. considera mais importantes?

( ) Prestar assistência médica aos associados

( ) Reivindicar aumentos de salários

( ) Prestar assistência jurídica na Justiça do Trabalho

( ) Defender os interesses e o ponto de vista dos trabalhadores perante o governo e a opinião pública

( ) Defender os interesses dos trabalhadores perante os patrões
48. O Sr. acha que os sindicatos estão cumprindo sua função?
( ) $\mathrm{Sim}$
( ) Não
( ) Depende
( ) Não sabe
( ) Sem resposta

48.1. Por que?

49. Algumas pessoas dizem que os sindicatos não devem intervir na política do país; outras dizem o contrário. Qual a sua opinião?

50. Já houve greve em alguma fábrica em que o Sr. trabalhava?

$$
\text { ( ) Não }
$$

( ) Sim - Qual a causa da greve? (verificar o comportamento do e. em relação à greve, sua participação, etc.)

51. Já houve greve na E. A.?
( ) Houve
( ) Não houve
( ) Sem resposta

52. Já houve alguma greve no setor da E. A.?
( ) $\mathrm{Sim}$
( ) Não
( ) Não sabe
( ) Sem resposta

53. Os operários da E. A. participam?
( ) Sim - Por quê?

( ) Não - Por quê?

54. a) Quando os operários desejam um aumento de salários e não conseguem, o Sr. acha que eles devem entrar em greve?
( ) $\mathrm{Sim}$
( ) Não
( ) Depende - Do quê?
( ) Não sabe
( ) Sem resposta

b) Por que alguns entram em greve e outros não entram? 
55. Os operários acham que as greves podem ajudar a melhorar sua situação?
( ) $\operatorname{Sim}$
( ) Não
( ) Depende
( ) Não sabe
( ) Sem resposta

56. O Sr. acha que nestes últimos anos a situação dos operários
( ) Melhorou
( ) Ficou a mesma coisa
( ) Piorou
( ) Depende
( ) Não sabe
( ) Sem resposta

56.1. Por quê?

57. E a do Sr.?
( ) melhorou
( ) Ficou a mesma coisa
( ) Piorou
( ) Depende
( ) Não sabe
( ) Sem resposta

57.1. Por quê?

58. Que possibilidades têm os operários de melhorar sua situação? Que devem fazer para isso?

59. Que possibilidades o Sr. tem de melhorar sua situação econômica?

60. O que é preciso fazer no Brasil para que a situação dos operários melhore?

61. O desenvolvimento do país tem beneficiado os trabalhadores?
( ) Tem
( ) Não tem
( ) Depende
( ) Não sabe
( ) Sem resposta

62. O Sr. acha que o governo do Jango tem beneficiado mais os trabalhadores do que os outros governos? (Por que tem beneficiado mais? Por que tem beneficiado menos?)

63. O que o governo precisa fazer para que o Brasil progrida?

64. Que tipo de governo poderia apressar o desenvolvimento do país e elevar o nível de vida do povo?

65. O Sr. é eleitor? a)-( ) - Sim b) ( ) - Não

66. Nas últimas eleições para Governador do Estado, o Sr. votou:
( ) Em Adhemar de Barros
( ) Em Jânio Quadros
( ) Em José Bonifácio
( ) Em Cid Franco
( ) Em branco
( ) Não votou

66.1. Por quê?

67. O Sr. lê jornal? (Marcar a frequência)

68. Qual o jornal que o Sr. lê?

69. Se o Sr. tivesse que escolher para Presidente da República entre o Lacerda e o Brizola, em quem o Sr. votaria?
( ) Lacerda
( ) Brizola
( ) Em nenhum deles
( ) Não sabe

69.1. Por quê?

70. De um modo geral, quem seria, na opinião do Sr., o melhor candidato para a Presidência da República?

71. Qual a idade do Sr.?

72. O Sr. segue alguma religião? (Verificar se é praticante ou não)

73. Sexo: 
74. Qual o seu estado civil?

75. O Sr. mora em casa
( ) Alugada
( ) Própria
( ) Outro

76. (Se alugada) - Quanto o Sr. paga mensalmente?

77. Mais alguém trabalha na família? (Anotar a posição do e. dentro da família)

78. Somando os salários de todos os que trabalham na família, quanto dá para tirar por mês?

79. O Sr. possui outro emprego (bico) além deste?

80. Instrução: (Verificar se o e. está fazendo algum curso)

81. O que o Sr. habitualmente faz aos domingos?

82. Quais destes objetos existem na casa em que o Sr. mora?

\begin{tabular}{|l|c|c|}
\hline & Existe & Não Existe \\
Televisão & $($ ) & $($ ) \\
Geladeira & $($ ) & $($ ) \\
Aspirador de pó & $($ ) & $($ ) \\
Máquina de lavar roupa & $($ ) & $($ ) \\
Rádio & $($ ) & $($ ) \\
Vitrola & $($ ) & $($ ) \\
Batedeira de bolo & $($ ) & $($ ) \\
Liquidificador & $($ ) & $($ ) \\
Enceradeira & $($ ) & $($ ) \\
Automóvel & $($ ) & \\
\hline
\end{tabular}

83. O Sr. costuma ir ao cinema? Com que frequência?

\section{AUTORES CitAdos}

ALMEIDA, Vicente Unzer de; MENDES SOB, Octávio Teixeira: Migração Rural-Urbana, São Paulo, Secretaria da Agricultura do Estado de São Paulo, 1951.

ANDERSON, Perry: "Les Origines de la Crise Presente", Les Temps Modernes, Paris, agosto-setembro de 1964.

ANDRADE, Celeste A. de Souza: "Migrantes Nacionais no Estado de São Paulo”, Sociologia, São Paulo, maio de 1952.

ARON, Raymond: La Lutte de Classes, Paris, Gallimard, 1964.

ASHTON, T. S.: La Revolución Industrial, México, Fondo de Cultura Económica, 1964.

BASTOS, Abguar: Prestes e a Revolução Social, Rio, Editorial Calvino, 1964.

BOLONHA, Ítalo: "Demanda de Mão de obra Especializada no Atual Surto Industrial Brasileiro", in: Educação Técnica e Industrialização, São Paulo, Centro e Federação das Indústrias do Estado de São Paulo, 1964.

BOTHEREAU, Robert: Histoire du Syndicalisme Français, Paris, Presse Universitaire de France, 1946.

BOSCO, Santa Helena; JORDÃO NETO, A.: Migrações, São Paulo, Departamento de Imigração e Colonização, 1967.

BREJON, Moysés: Racionalização do Ensino Industrial, São Paulo, Faculdade de Filosofia, Ciências e Letras (USP), 1962.

CAMARGO, José Francisco: Crescimento da População de São Paulo e seus Aspectos Econômicos, São Paulo, Faculdade de Filosofia, Ciências e Letras (USP), 1952.

Exodo Rural no Brasil, São Paulo, Faculdade de Ciências Econômicas e Administrativas (USP), 1957.

CARDOSO, Fernando Henrique: "Le Prolétariat Brésilien: Situation et Comportement Social", in: Ouvriers et Syndicats d'Amérique Latine, número especial da revista Sociologie da Travail, Paris, n. ${ }^{\circ}$ 4, 1961. 
: "Condições e Fatores Sociais da Industrialização em São Paulo", Revista Brasileira de Estudos Políticos, Belo Horizonte, junho de 1961.

- Empresário Industrial e Desenvolvimento Econômico, São Paulo, Difusão Europeia do Livro, 1964.

: "Hégémonie Bourgeoise et Imlépendence Économique", Les Temps Modernes, Paris, outubro de 1967.

CARVALHO, Orlando M.: "Os Partidos Nacionais e as Eleições Parlamentares de 1958”, Revista Brasileira de Estudos Políticos, Belo Horizonte, abril de 1960.

CENTERS, Richard: The Psychology of Social Classes, Nova York, Russel \& Russel, 1961.

CHINOY, Ely: Automobile Worker and the American Dream, Boston, Beacon Press, 1955.

: "The Tradition of Opportunity and the Aspirations of the Automobile Worker", in: Joseph Bensman e Bernard Rosenberg: Anierican as a Mass Society, The Pree Press of Glencoe, 1963.

CHUCID, Sara; LOWY, Michel: “Opiniões e Atitudes de Lideres Sindicais Metalúrgicos", Revista Brasileira de Estudos Políticos, Belo Horizonte, janeiro de 1962.

CLARK, Alfred C.: "Leisure and Occupational Prestige", in: Eric Larrabee e Rolf Meyerson, Mass Leisure, The Free, Press of Glencoe, 1960, 2a ed.

COLE, G. D. H.: A Short History of the British Working-Class, Londres, Georges Allen and Unwin, 1945.

COUTO. Francisco Pedro: O Voto e o Povo, Rio, Civilização Brasileira, 1966. DAHRENDORF, Ralf: "Politique Syndicale et Structure des Entreprises em Allemagne", Sociologie du Travail, Paris, abril-junho de 1962.

DI TELLA, Torcuato: "Populismo y Reforma en América Latina", Desarrollo Económico, Buenos Aires, janeiro-março de 1961.
DICKSON, W. J.; ROETHLISBERG, F. I.: Management and the Worker Cambridge, Harvard University Press, 1939.

DIAS, Everardo: História das Lutas Sociais no Brasil, São Paulo, Editora Edaglit, 1962.

DIEGUES JÚNIOR, Manuel: Imigração, Urbanização e Industrialização, Rio, Centro Brasileiro de Pesquisas Educacionais, 1964.

DOFNY, Jacques: "Positions Recentes des Syndicats Américains à l'Égard de l'Automation", Sociologie da Travail, Paris, julho-setembro de 1961.

DOLLEANS, Édouard: Histoire du Mouvement Ouvrier, Paris, Librairie Armand Colin, 1953, 3 vols.

DUNIAZEDIER, Joffre: Vers une Civilisation du Loisir?, Paris, Editions du Senil, 1962

: "Trabajo y Recreación", in: Georges Friedmann e Pierre Naville, Tratado de Sociologia del Trabajo, México, Fondo de Cultura Económica, 1963, $2^{\circ}$ vol.

DURHAM, Eunice Ribeiro: Migração, Trabalho e Família, São Paulo, Faculdade de Filosofia, Ciências e Letras, 1966 (mim.).

ECHAVARRÍA, José Medina: Consideraciones Sociológicas sobre el Desarrollo Económico, Buenos Aires, Solar-Hachete, 1964.

FALETTO, Enzo: "Industrialização e Classe Operária na América Latina”, in: Leôncio Martins Rodrigues (ed.), Sindicalismo e Sociedade, São Paulo, Difusão Europeia do Livro, 1968.

FERNANDES, Florestan: Mudanças Sociais no Brasil, São Paulo, Difusão Europeia do Livro, 1960.

: A Integração do Negro à Sociedade de Classes, São Paulo, Editora Nacional, 1966, 2 vols.

: "Crescimento Econômico e Instabilidade Política no Brasil", Comunicação aos VI Colóquios Luso-Brasileiros, Columbia University-Harvard University, Nova York, 1966 (dat.). 
FERREIRA, Oliveiros S.: "Comportamento Eleitoral em São Paulo", Revista Brasileira de Estudos Políticos, Belo Horizonte, abril de 1960.

FIGUEIREDO, Antônio dos Santos: A Evolução do Estado no Brasil, Porto, Empr. Indúst. Gráfica do Pôrto, 1926.

FRIEDMANN, Georges: "De Quelques Incidences Psicologique, Sociale e Morale dans l'Évolution Contemporaine des Métiers Industrieis", in: L’Année Sociologique, 3. ${ }^{\text {a }}$ série, 1940-1948, Paris, Presse Universitaire de France, tomo III, 1949.

: Problemas Humanos del Maquinismo Industrial, Buenos Aires, Editorial Sudamérica, 1956.

: El Trabajo Desmenuzado, Buenos Aires, Editorial Sudamérica, 1958.

: "Tendencias de Hoy, Perspectivas de Manana", in: Georges Friedmann e Pierre Naville, Tratado de Sociologia del Trabajo, México, Fondo de Cultura Económica, 1963, 2 vols.

FRISCH-GAUTHIER, Jacqueline: "Moral y Satisfacción en el Trabajo" in: Georges Friedmann e Pierre Naville, Tratado de Sociologia del Trabajo, México, Fondo de Cultura Económica, 1963, 2 vols.

FURTADO, Celso: Dialética do Desenvolvimento, Rio, Fundo de Cultura, 1964.

GALENSON, Walter: La Clase Obrera y el Desarrollo Económico, México, Editorial Limusa-Wiley, 1964.

GERMANI, Gino: Política y Sociedad en una Época de Transición, Buenos Aires, Editorial Paidos, 1962.

GORZ, André: Stratégie Ouvrière et Néocapitalisrne, Paris, Seuil, 1964.

GUEST, Robert H.; WALKER; Charles: The Man on the Assembly Line, Massachussets, Harvard University Press, 1952.

GURVITCH, Georges: El Concepto de Clases Sociales de Marx a Nuestros Dias, Buenos Aires, Ediciones Galatea-Nueva Visión, 1960, 2. a ed.
HIRSCH-WEBER, Wolfgang: Los Sindicatos en la Política, Madri, Editorial Tecnos, 1964.

HUTCHINSON, Bertram: Mobilidade e Trabalho, Rio, Centro Brasileiro de Pesquisas Educacionais, 1960.

IANNI, Octávio: Industrialização e Desenvolvimento Social no Brasil, Rio, Editoria Civilização Brasileira, 1963.

Estado e Capitalismo, Rio, Editora Civilização Brasileira, 1965.

KERR, Clark; SIEGEL, Abrahan: "The Interindustry Propensity to Strike: An International Comparison", in: Robert Dubin, Arthur Kornhauser e Arthur Ross: Industrial Conflict, Nova York, MacGraw-Hill, 1954.

KNOWLES, K. G. J. C.: Strikes, a Study in Industrial Conflict, Nova York, Philosophical Library, 1952.

LAIDLER, Harry W.: Social-Economics Movements, Nova York, Thomas Y. Crowel, 1945, 2. ${ }^{\text {a }}$ ed.

LANDSBERGER, Henry: "La Elite Obrera de Latinoamerica y la Revolución", in: S.M. Lipset e A. Solari (eds.): Elites y Desarrollo en América Latina, Buenos Aires, Paidos, 1967.

BARRERA, Manuel; TORO, Abel: "The Chilean Labor Union Leaders: A Preliminary Report on his Background and Attitudes", Industrial and Labor Relations Review, Nova York, abril de 1964, reprint series $n .^{\circ} 150$.

LANGDON, J. N.; WYATT, S.; STOCK, F.G.L.: Fatigue and Boredom in Repotitive Work, Londres, Industrial \& Health Research Board, Report 77, 1937.

LARRUE, Janine: "Loisirs Ouvriers et Participation Sociale”, Sociologie du Travail, Paris, janeiro-março de 103.

LEAL, Victor Nunes: Coronelismo, Enxada e Voto, Rio, Revista Forense, 1948.

LINHARES, Hermínio: Contribuição à História das Lutas Operárias no Brasil, Rio, Baptista Souza e Cia., 1955. 
LIPSET, Seymour Martin: "Le Prolétariat Americain et les Valeurs de la Societe Americaine", Sociologie du Travail, Paris, números de abriljunho e julho-agosto de 1961.

: "Working-Class Authoritarianism: A Reply to Miller and Riessman", The British Journal of Sociology, setembro de 1961.

: El Hombre Político, Buenos Aires, Eudeba, 1963.

; GORDON, Joan: "Mobility and Trade-Union Membership" in: Reinhard Bendix e Seymour Martin Lipset (eds.): Class, Status and Power, The Free Press of Glencoe, 1961, 5a

LOPES, Juarez R. Brandão: Sociedade Industrial no Brasil, São Paulo, Difusão Europeia do Livro, 1964.

LUKACS, Georg: Histoire et Conscience de Classe, Paris, Minut, 1960.

LUTZ, Bukart: "Le Syndicats Allemands au Debut des Armes 60", Sociologie du Travail, Paris, janeiro-março de 1964.

MALLET, Serge: La Nouvelle Classe Ouvrière, Paris, Senil, 1963.

MANTOUX, Paul: La Revolución Industrial en el Siglo XVIII, Madri, Aguilar, 1962.

MARCONDES, J. V. Freitas: Radiografia da Liderança Sindical Paulista, São Paulo, Instituto Cultural do Trabalho, 1964.

MILLER, S. M.; RIESMAN, Frank: "Working-class Authoritarianism: a Critique of Lipset", The British Journal of Sociology, Londres, setembro de 1961.

MOORE, Wilbert E.: Industrial Relations and the Social Order, Nova York, The MacMillan Co., 1956, 2. a ed.

MORAES FILHO, Evaristo de: O Sindicato Único no Brasil, Rio, Editora "A Noite", 1962.

MONTREUIL, Jean: Histoire du Mouvement Ouvrier en France, Paris, Aubier, 1946.

MOTTEZ, Bernard; TOURAINE, Alain: "Classe Obrera y Sociedad Global" in: Georges Friedmann e Pierre Naville: Tratado de
Sociologia del Trabajo, México, Fondo de Cultura Económica, 1963, 2 vols.

NAVILLE, Pierre: Essai sur la Qualification du Travail, Paris, Librairie Marcel Riviere, 1956.

PATERSON, Florence: American Labor Unions, Nova York, Harper \& Brother Publisher, 1952.

PELLING, Henry: A History of the British Trade Unionism, Londres, Pelican Book, 1963.

PEREIRA, Astrogildo: Formação do PCB, Rio, Vitória, 1962.

PEREIRA, Luiz: Trabalho e Desenvolvimento no Brasil, São Paulo, Difusão Europeia do Livro, 1965.

PERLMAN, Mark: Labor Unions Theories in America, Illinois, Row, Peterson and Co., 1958.

PERLMAN, Selig: A Theory of the Labor Movement, Nova York, August M. Kelly, 1949, 2. ${ }^{\text {a }}$ ed.

PRADO JR., Caio: A Revolução Brasileira, São Paulo, Editora Brasiliense, 1966.

RABELLO, Ophelia: A Rede Sindical Paulista, São Paulo, Instituto Cultural do Trabalho, 1965.

RAGAZZI, Orietta; TOURAINE, Alain: Ouvriers d'Origine Agricola, Paris, Senil, 1961.

RAYBACK, Joseph: A History of American Labor, Nova York, The MacMillan Co., 1959.

RODRIGUES, José Albertino: O Sindicato no Brasil. Seu papel no Desenvolvimento Econômico, São Paulo, Difusão Europeia do Livro, 1968.

: "Padrão de Vida da População Brasileira", Revista de Estudos Sócio-Econômicos, São Paulo, novembro de 1961.

: "Situação Econômico-Social da Classe Trabalhadora no Brasil", Revista de Estudos Sócio-Econômicos, São Paulo, setembro de 1961. 
RODRIGUES, Leôncio Martins: Conflito Industrial e Sindicalismo no Brasil, São Paulo, Difusão Europeia do Livro, 1966.

(ed.): Sindicalismo e Sociedade, São Paulo, Difusão Europeia do Livro, 1968.

: "Sindicalismo y Desarrollo en el Brasil", Revista Latinoamericana de Sociologia, Buenos Aires, n. ${ }^{\circ} 1,1966$.

ROSS, Arthur “Les Relations Professinnelles aux É'tats-Unis dans les dix annés à venir", Sociologie du Travail, Paris, abril-junho de 1962.

SANTI, Paolo: "Les Syndicats et la Politique de Controle de Salaire", Les Temps Modernes, Paris, agosto-setembro de 1964.

SANTOS, Milton: A Cidade nos Países Subdesenvolvidos, Rio, Editora Civilização Brasileira, Rio, 1965.

SCHNEIDER, Eugene V.: Industrial Sociology, Nova York, McGraw-Hill Book, 1957.

SOARES, Gláucio A. Dillon: "Classes Sociais, Strato Sociais e Eleições Presidenciais em 1960”, Sociologia, São Paulo, setembro de 1961.

- "Alianças e Coligações Eleitorais: Notas para uma Teoria", Revista Brasileira de Estudos Políticos, Belo Horizonte, julho de 1964.

SOARES, Gláucio A. Dillon: "As Bases Ideológicas do Lacerdismo", Revista Civilização Brasileira, Rio, setembro de 1965.

SIMÃO, Azis: "O Voto Operário em São Paulo”, Anais do I Congresso Brasileiro' de Sociologia, São Paulo, 1955.

: "Industrialisation et Syndicalisme au Brésil", in: Ouvriers et Syndicats d'Amérique Latina, número especial da revista Sociologia da Trovoa, Paris, n. ${ }^{\circ} 4,1961$.

: O Sindicato e o Estado, São Paulo, Dominus Editora, 1966.

TOPHAN, Tony: "Shop Steward, Controle Ouvrier et Syndicats", Les Temps modernes, Paris, agôsto-setembro de 1964.
TOURAINE, Alain: "Industrialisation et Conscience Ouvrière à São Paulo", in: Ouvriers et Syndicats d'Amérique Latine, número especial da revista Sociologie de Travail, Paris, n. ${ }^{\circ} 4,1961$.

: La Conscience Ouvrière, Paris, Senil, 1966.

TRENTIN, Bruno: "Les Syndicats Italiens et le Progres Technique", Sociologie da Travail, Paris, abril-junho de 1962.

VIANNA, Oliveira: Problemas do Direito Corporativo, São Paulo, José Olympio, 1938.

: Problemas do Direito Sindical, Rio, Editora Max Limonad, 1943.

Oliveira: Direito do Trabalho e Democracia Social, São Paulo, José Olympio, 1951

WALLINE, Pierre: Les Syndicats aux États-Unis, Paris, Librairie Armand Colin, 1951.

WEBB, Sidney e Beatrice: History of Trade-Unionism, Londres, Longmans Green and Co., 1950.

WEFFORT, Francisco C.: "Raízes Sociais do Populismo em São Paulo", Revista Civilização Brasileira, Rio, maio de 1965.

Classes Populares e Política (Contribuição ao Estudo do Populismo), São Paulo, Faculdade de Filosofia, Ciências e Letras (USP), 1968 (mim)

: "Estado y Masas en el Brasil", Revista Latino-americana de Sociologia, Buenos Aires, março de 1965.

WHITE, Clyde: "Social Class Differences in the Uses of Leisure", in: Eric Larrabee e Rolf Meyerson (eds.): Mass Leisure, The Free Press of Glencoe, 1960, 2. ${ }^{\mathrm{a}}$ ed.

\section{Outros documentos}

"Condições de Trabalho na Indústria Têxtil", Boletim do Departamento Estadual do Trabalho, ano I, n. ${ }^{\text {os }} 1$ e 2, São Paulo, Conjuntura Econômica: Migrações Internas”, ano VII, n. ${ }^{\circ}$ 10, outubro de 1953 
Conjuntura Econômica: "Migrações Internas - São Paulo", ano VIII, n. ${ }^{\circ}$ 7, julho de 1954.

Conjuntura Econômica: "Crescimento da População nas Capitais", ano X, n. ${ }^{\text {os }} 4$ e 5, maio-junho de 1956.

Conjuntura Econômica: "Correntes de Migração Interna", ano IX, n. ${ }^{\circ}$ 12, dezembro de 1955.

Estatística de Imigração, Departamento de Imigração e Colonização, Secretaria de Agricultura do Estado de São Paulo, São Paulo, 1961.

Indústria Automobilística Brasileira, Sindicato Nacional de Tratores, Caminhões, Automóveis e Veículos Similares, São Paulo, novembro de 1964.

Relatório do Serviço Nacional de Aprendizagem Industrial, São Paulo, 1960.

V Estudos Marplan (Média e Superposição). Segundo semestre de 1963, Marplan - Pesquisas e Estudos de Mercado Ltda.

Programa Estratégico de Desenvolvimento (1968-1970), estudo especial "A Industrialização Brasileira: Diagnóstico e Perspectivas", Ministério do Planejamento e Coordenação Geral, janeiro de 1969. 